\title{
Advance care planning in pediatrics
}

\section{Development and pilot evaluation of the IMplementing Pediatric Advance Care Planning Toolkit}

\author{
Jurrianne Christiana Fahner
}


Advance care planning in pediatrics

PhD thesis. Department of Medical Humanities, Julius Center for Health Sciences and Primary Care, University Medical Center Utrecht, Utrecht, The Netherlands

ISBN:

Author: Jurrianne Christiana Fahner

Cover design:

Layout \& printing:

This study was supported by the Netherlands Organisation for Health Research and Development (grant number 844001206).

(C) J.C. Fahner, 2020

All rights reserved. No parts of this thesis may be reproduced in any form without written permission from the authors or, as appropriate, of the publishers of the publications. 


\title{
Advance care planning in pediatrics
}

\section{Development and pilot evaluation of the IMplementing Pediatric Advance Care Planning Toolkit}

\section{PROEFSCHRIFT}

\author{
ter verkrijging van de graad van doctor aan de Universiteit Utrecht \\ op gezag van de rector magnificus, prof.dr. H. Kummeling, \\ ingevolge het besluit van het college voor promoties \\ in het openbaar te verdedigen op
}

dinsdag 20 oktober 2020 des middags te 4.15 uur

door

Jurrianne Christiana Fahner

geboren op 12 december 1985

te Ede 
Promotoren: $\quad$ Prof. dr. J.J.M. van Delden

Prof. dr. A. van der Heide

Copromotoren: Dr. M.C. Kars

Dr. J.A.C. Rietjens 


\section{Table of contents}

Chapter 1 General introduction 1

Chapter 2 Interventions guiding advance care planning conversations: a systematic 20 review

Chapter 3 Anticipating the future in pediatric palliative care: a qualitative study 71 into the perspectives of parents and healthcare professionals

Chapter 4 Survey of paediatricians caring for children with life-limiting conditions 90 found that they were involved in advance care planning

Chapter 5 Towards advance care planning in pediatrics: a qualitative study on envisioning the future as parents of a seriously ill child

Chapter 6 Evaluation showed that stakeholders valued the support provided by the Implementing Pediatric Advance Care Planning Toolkit

Chapter 7 Advance care planning for children with life-limiting conditions: content and documentation of conversations based on the IMplementing Pediatric Advance Care Planning Toolkit

Chapter 8 Experiences with an advance care planning intervention for children with life-limiting conditions: a qualitative study of families and clinicians using the IMplementing Pediatric Advance Care Planning Toolkit

Chapter 9 General discussion

Additional tables Systematic review (Chapter 2)

Topic lists Anticipating the future (Chapter 3)

Questionnaire Survey study (Chapter 4)

Topic lists Developmental phase (Chapter 5 and 6)

Topic lists Pilot phase (Chapter 6,7 and 8)

List of Publications 
Chapter 1

General introduction 


\section{Introduction}

'We had two healthy boys, and we were very happy when our beautiful little girl was born. After birth everything seemed perfect to us. However, the pediatrician had her concerns. A journey of medical investigations begun. A journey between hope and fear. Finally, it turned out she had a severe metabolic disorder without any treatment options. From that moment on, we knew that we would not have our daughter with us for many years. Although the news was quite hard, it gave us some peace of mind. We embraced our daughter with love and care at the heart of our family, while facing an uncertain future. 'Will she die?' one of her brothers asked one day. I struggled to answer and we all cried. Then her other brother said: 'Mummy, do not worry, we do have an angel to care for instead of a family's princess.' You know what, when I am worried about the future, his words keep me going, every day.'

Based on an interview with a mother participating in the IMPACT study

Anticipating the future is a challenge for most people, since it includes an attempt to face the uncertainties the future holds. For children with life-limiting conditions, their parents and other family members, facing the future is even more challenging, since it confronts them with ongoing losses, their coping strategies and often a need for decision making about future care and treatment. In pediatrics, clinicians caring for families of children with life-limiting conditions need strategies to support families in anticipating the future in order to achieve high-quality care in the best interest of the child and aligned to the values, goals and preferences of the family. This chapter provides an introduction on facing the future of children with life-limiting conditions and their families and shows how the research questions of this thesis arose.

Care for children with life-limiting conditions

Medical and technological advances have increased the life expectancy of seriously ill children, resulting in a growing population of children living with life-limiting conditions. ${ }^{1,2}$ Life-limiting conditions are conditions with no curative treatment options leading to a premature death, or conditions that might be cured, but could also lead to a premature death. ${ }^{2,3}$ In the Netherlands, there are about 4000-6700 children living with life-limiting conditions. ${ }^{4}$ About 1000 of these children die annually. ${ }^{5}$ Children with life-limiting conditions often receive highly complex chronic care for a long period of time. ${ }^{6,7}$ Disease trajectories are marked by frequent hospital admissions 
and high healthcare use, especially at the end of life. ${ }^{6}$ The high complex care needs lead to challenging medical decision making and a need for expertise in communication with families to support them throughout the disease trajectories of their child. ${ }^{8-10}$

Children with life-limiting conditions and their families might benefit from early initiation of pediatric palliative care, including conversations about goals of care. ${ }^{1,8,11,12}$ Whereas palliative care is still often seen as end of life care, the definition of the World Health Organization clearly states palliative care is a philosophy of providing care to those living with life-limiting conditions, focused on improving the quality of life of patients and families. ${ }^{13}$ Palliative care starts from diagnosis of a life-limiting condition, regardless of any disease-directed treatments, and continues into bereavement care. Palliative care is the active total care of the child's body, mind and spirit and also involves giving support to the family. ${ }^{13}$

Pediatric palliative care is rapidly evolving towards provision of long-term care to children with life-limiting conditions and their families. Compared to adult care, children with life-limiting conditions receive palliative care for a longer period of time, with most of them being alive one year after initiation of palliative care. ${ }^{1}$

In the Netherlands, pediatric palliative care teams were founded in all seven pediatric academic hospitals during recent years, aimed at early and sustainable integration of palliative care for children with life-limiting conditions. The recently founded national center of expertise on pediatric palliative care attempts to concentrate all expertise on pediatric palliative care to provide excellent support to clinicians involved in this care. ${ }^{14}$ Clinicians are supported by regional networks of palliative care experts in the field, including representatives from the national center of expertise and members of the academic pediatric palliative care teams. A national guideline, that is currently under revision, stimulates a high-quality, evidence-based approach of pediatric palliative care, mainly focused on symptom management. ${ }^{15}$ Whereas symptom management is seen as one of the core elements of pediatric palliative care by both clinicians and families, ${ }^{1,9}$ the need for strategies to support communication about goals of care and shared-decision making is increasingly recognized as a priority in pediatric palliative care. ${ }^{16,17}$ These strategies need to integrate the child's best interests with the families' needs and 
coping strategies. ${ }^{18}$ Early integration of pediatric palliative care creates opportunities to talk about preferences of the child and family regarding future care and treatment early in disease trajectories before the end of life. With the long-time involvement of clinicians in the care for children with life-limiting conditions and their families, opportunities to face the future can be used to define goals of care before a crisis occurs or death is imminent. In pediatrics, the disease courses of life-limiting conditions often entail one or more episodes of physical decline that precede the end of life. ${ }^{3}$ This creates opportunities to anticipate future scenarios and explore in advance individual values and preferences of the child and family before the occurrence of a serious event.${ }^{11}$ At the same time, periods of recovery may happen, where preferences for care and treatment may focus on living a life as normal as possible and living a meaningful life.,19

\section{A person-centered approach to care}

The support of children with life-limiting conditions and their families in living a meaningful life in line with their goals and preferences for care and treatment, is increasingly seen as an important task for healthcare providers. ${ }^{18,20}$ Exploration of values and needs in the social, psychological and spiritual domains besides the medical domain, facilitates attention to the personality and identity of the child and family. In this way, a person-centered approach to care can be achieved. In the model of person-centered care, the patient has a central and active role as a person in decision making and organizing his or her healthcare, with the ultimate aim of living a meaningful life. ${ }^{21}$ Clinicians and patients work together as partners to achieve a holistic, individualized, respectful and empowering approach to care. ${ }^{22}$ The concept of person-centered care evolved from the concept of patient-centered care, that also involves the patient as an unique person, but with a stronger focus on disease, medical care and treatment. ${ }^{23} \mathrm{~A}$ shift in the orientation of care from patient to person is also identified in initiatives to redefine the concept of health. Whereas the concept of health was defined by maintenance of a state of complete physical, mental and social well-being, ${ }^{24}$ a shift towards an individualized person-oriented concept is seen in literature. ${ }^{25}$ Health is seen as a dynamic concept based on the ability to adapt and to self-manage. ${ }^{25}$ This indicates there is a need for integration of individualized values, 
goals and preferred coping strategies to arrange care and treatment in a way contributable to quality of life, as perceived by the patient.

Involving children in their own healthcare to reach a person-centered approach of care is challenging, yet considered an ethical obligation in high-quality pediatric care. ${ }^{26-29}$ Besides the influence of age and developmental stage on the level of involvement of the child, family dynamics also play an important role. The unique and strong bond between children and their family, can both facilitate and complicate care provision aligned to the child's wishes and best interests. ${ }^{30}$ Therefore, often a process of shared management, involving the child and the family, rather than a process of self-management of the child is needed. ${ }^{31}$ Some experts even conclude that family matters can prevail above the child's interests to protect a family's integrity. ${ }^{32}$ Person-centered care in pediatrics needs a family-centered approach, in which both preferences and values of the individual child and of other family members are elicited.

Both the early integration of pediatric palliative care for children with life-limiting conditions and a person-centered approach to care in general, set out a framework in which strategies to provide future care aligned to individual patient' values and preferences can be further developed. Advance care planning is such a strategy, which has gained increased attention lately, mainly in adult care.

The concept of advance care planning

Advance care planning (ACP) is increasingly emphasized as a valuable strategy to explore individual values and preferences, even more in the challenging context of life-limiting conditions. ${ }^{33}$ ACP is aimed at providing care concordant with patient preferences. Whereas ACP initially focused on documentation of preferences regarding life-sustaining treatments, the wellknown code status, this showed to have limited contribution to person-centered care. ${ }^{34}$ On the contrary, patients felt unheard and forced to make end-of-life decisions in advance. ${ }^{35}$ From thereon ACP evolved over the years into a concept focused on personal conversations between patients and healthcare providers about goals and preferences for future care and treatment. In 2017, an international panel headed by a task force of the European Association for Palliative Care (EAPC) defined ACP as a process to enable patients to define preferences and goals for 
care, to discuss these preferences with healthcare providers and family and to document and review these, if appropriate. ${ }^{33}$ This definition applies to competent adults, to prepare them and their surrogates for situations they might become incompetent in decision making. However, the main elements of ACP as proposed by the EAPC definition, the identification, discussion and documentation of goals and preferences for future care and treatment, are applicable to pediatrics as well. Nevertheless, specific interventions to implement ACP in pediatrics might be needed.

In adult care, evidence indicates ACP might have a beneficial effect on several outcomes, such as increased prevalence of advance directives, increased concordance between preferred and received care, improved quality of life, increased patient-family concordance regarding preferences for medical care and better quality of patient-clinician communication. ${ }^{36,37}$ Evidence on current pediatric ACP approaches shows higher documentation rates of advance directives, increased dyad congruence and increased knowledge about ACP and options in end-of-life care. ${ }^{37}$ Families and clinicians value the concept of pediatric ACP, even earlier in disease trajectories than is customarily practiced. ${ }^{38-40}$ Nevertheless, more than $70 \%$ of pediatric clinicians rated current occurrence of ACP discussions as infrequent and too late. ${ }^{41}$

Eliciting individual values and preferences for care and treatment has not been easy in the context of healthcare. ACP faces several barriers, such as prognostic uncertainty, identification of eligible patients, adequate timing to initiate ACP, fear to cause emotional distress among families, provider's lack of time and differences in illness understanding among clinicians and families. ${ }^{42}$ On the patient side ACP requires the ability and willingness to look towards a future while facing the possibility of disease progression and deterioration. ${ }^{43}$ On the clinician side, excellent communicative skills are required to explore patient' perspectives independently from the clinicians' personal or expertise-based viewpoints on care and treatment. ${ }^{43,44}$

Barriers to ACP might be even more prominent in pediatrics, were prognostication is more difficult compared to adult care, due to relatively small numbers of patients, wide range of sometimes unspecified diagnoses and limited data on diseases courses. ${ }^{1,41}$ Besides prognostic uncertainty, facing the certainty of the child's death somewhere in the future, causes severe 
emotional distress, leading to avoidant coping strategies among families and clinicians. Clinicians perceived parental factors, such as, unrealistic expectations, understanding of the prognosis and readiness to have an ACP conversation, as the most significant barriers. ${ }^{41}$

\section{Strategies to facilitate advance care planning in pediatrics}

Although multiple pediatric associations emphasize the value of $A C P,{ }^{45-47}$ limited research has been done to identify appropriate and effective approaches for pediatric ACP. Whereas in adult care the number of interventions and strategies to support implementation of ACP in daily care is rapidly growing, standardized ACP approaches in pediatrics are scarce. ${ }^{37,48}$ Interventions from adult care need adjustment to be suitable for use in pediatrics due to the position of the developing child, the involvement of parents, a broad diversity in disease trajectories and specific needs in pediatric end-of-life care. In addition, existing ACP programs often consist of complex interventions with multiple interacting components. This complicates the determination of essential elements for adaptation to a pediatric setting. Furthermore, detailed descriptions of these complex interventions are often lacking in the literature, which hinders their applicability in other contexts. ${ }^{49,50}$ The most well-investigated and comprehensive ACP intervention, adapted for use in pediatrics, is the Family Centered advance care planning (FACE) intervention, which is based on Respecting Choices, one of the most widespread ACP interventions in adult care. ${ }^{51,52}$ The intervention content is protected by a copyright and not freely available, complicating any evaluation for use in other contexts.

Interventions including FACE, that have been adapted for use in pediatrics focus mainly on specific patient populations. These include adolescents and young adults with cancer and patients living with acquired immune deficiency syndrome. ${ }^{52-56}$ The focus of these studies, on adolescents and their end-of-life preferences, might hinder both their earlier use in disease trajectories and their use with younger children and their parents. Other pediatric ACP approaches reported in literature, are described more in general, without detailed descriptions of specific intervention components or they focus on the documentation of goals and preferences for future care and treatment. ${ }^{57-62}$ In addition to evidence-based approaches, there are also practice-based initiatives funded by governments or healthcare institutions. ${ }^{63}$ However, 
the evidence and rationale for these programs is often unclear, limiting their use in the research and development of pediatric ACP.

\section{Objectives and research questions of this thesis}

Despite the potential added value of ACP for a broad population of children living with lifelimiting conditions, a well-described, comprehensive, evidence-based intervention to facilitate ACP for children with life-limiting conditions and their families early in disease trajectories and continuing until the end of life is lacking. This research project aimed to develop a well-defined, evidence-based intervention to conduct ACP in pediatrics with children with life-limiting conditions and their families, aimed at providing future care and treatment aligned to the child's and families' values, goals and preferences.

The first objective of this project was to identify the key elements of pediatric ACP. Both adult and pediatric approaches as described in literature were evaluated to assess their structure and content. Stakeholders in pediatric palliative care and pediatrics in general, were involved from the very start of the project to specify additional needs in pediatric ACP. The first objective included the following research questions:

1.1 What are the structure, content, theoretical background and empirical evidence of adult and pediatric ACP interventions based on a conversation guide? (Chapter 2)

1.2. How do clinicians and parents anticipate the future of children receiving pediatric palliative care? (Chapter 3)

1.3. How do pediatricians envisage the concept of ACP in general and to what extent do they engage in ACP in their daily practice? (Chapter 4)

1.4. How do parents face the future while caring for a child with a life-limiting condition? (Chapter 5)

The second objective was to design an intervention based on the identified key elements and needs in pediatric ACP. This second objective led to the development of the IMplementing Pediatric Advance Care Planning Toolkit (IMPACT), guided by the following research question: 
2.1 What are components of a pediatric ACP intervention based on current evidence, underlying theories and stakeholders' perspectives? (Chapter 6)

The third objective was to evaluate early experiences with the use of IMPACT in order to understand ways of acting and to gain insight in additional needs when using the intervention in daily practice. This objective led to the following research questions:

3.1. What are the content and characteristics of ACP conversations and related documentation conducted by clinicians using IMPACT? (Chapter 7)

3.2. What are the experiences of clinicians and families regarding ACP conversations based on IMPACT? (Chapter 8)

\section{Methods}

Study design

The Medical Research Council (MRC) Framework for the Development and Evaluation of Complex Interventions was used to structure the research project. ${ }^{64}$ In 2000, the MRC of the United Kingdom presented the framework. Initially, the framework focused on the development of interventions to be tested in experimental study designs. In 2008, the framework was adjusted and became more applicable for non-experimental studies. ${ }^{65,66}$ The MRC model consists of four iterative phases: 1) development of the intervention, 2) assessing feasibility and piloting methods, 3) evaluation, and 4) implementation. Our research project covers the development of the intervention and a first pilot study.

According to the MRC-model the developmental phase of complex interventions consists of three elements: identifying the evidence base, identifying or developing appropriate theory, and modelling process and outcomes. We translated these elements into four steps in the developmental phase of this research project, tailored to our study aims and research questions. These steps were: 
- Identification of current evidence on ACP by a systematic review of complex interventions guiding ACP conversations and by expert consultation on evidence for pediatric ACP approaches, both nationally and internationally;

- Exploration of the perspectives of children with life-limiting conditions, parents and clinicians towards ACP. A cross-sectional national survey study was conducted among pediatricians working in pediatric academic hospitals. The online questionnaire evaluated their experiences and attitudes with ACP in their most recent case of a deceased child and with ACP in general; Qualitative interview studies were performed to get insight in the perspectives on facing the future of children with life-limiting conditions, their parents and clinicians in pediatric palliative care and in general;

- Design of a theoretical framework based on existing theoretical concepts in relation to the identified key elements of pediatric ACP in the prior steps;

- Modelling the input from prior steps into individual and specific intervention components, resulting in IMPACT;

The pilot phase consisted of the fifth step in our research project.

- Fine-tuning the intervention materials based on experiences of clinicians and families after use of IMPACT and evaluating first experiences with IMPACT to achieve a deeper understanding of ways of acting and to reveal further directions for improvement and implementation;

\section{Study population}

This research project focused on Dutch-speaking children with life-limiting conditions under the age of 18 , their parents and clinicians. Participants in the sub studies of the developmental phase were purposively recruited from pediatric academic hospitals during September 2016 and November 2018. A total of 168 pediatricians caring for children with life-limiting conditions were included in the survey study. Individual interviews were conducted with 17 pediatricians and a specialized nurse caring for children with life-limiting conditions to gain deeper insight in their perspectives regarding ACP. A qualitative interview study analyzed the perspectives of 20 parents of children with life-limiting conditions on ACP, including ten bereaved parents. The 
perspectives on IMPACT of children living with a life-limiting condition were explored at the start of the pilot study. Thirteen children, aged 11 to 18 years, with diverse medical backgrounds participated.

Participants of the pilot study were recruited from pediatric academic hospitals, hospice and home care during February and September 2019. Eleven physicians and seven nurses experienced in the care for children with life-limiting conditions were purposively recruited to attend the IMPACT training. Subsequently, these clinicians invited parents of children with lifelimiting conditions to participate in the study. Children were invited to participate depended on their age and mental state. A total of 27 cases of children with life-limiting conditions were included, resulting in the participation of 26 mothers, 15 fathers and five children in the pilot study.

\section{Data collection and analysis}

Based on the study design with different sub studies, data collection and analysis yielded several strategies. The survey study was based on an online questionnaire and descriptive statistics were reported. The qualitative studies of the development and pilot phase were based on individual or focus group interviews. These interviews were audio recorded and transcribed verbatim. A thematic analysis was performed.

\section{Outline of the thesis}

This research project started with a systematic review on interventions guiding advance care planning conversations, which is presented in Chapter 2.

In Chapter 3, a qualitative study is presented, exploring how parents of children with a lifelimiting condition and their clinicians anticipate the future when care is provided by a pediatric palliative care team

Chapter 4 describes the results of a survey study among pediatricians caring for children with life-limiting conditions about their experiences, attitudes and skills regarding advance care 
planning. Pediatricians were surveyed about their experiences with ACP in their latest case of a deceased child and about their perspectives regarding ACP in general.

In Chapter 5, the results of a qualitative study among parents of children with life-limiting conditions are reported. This study explores how parents envision the future and to what extent they share future perspectives with clinicians.

The results of these chapters constitute the main input of the developmental phase of the IMPACT intervention, as described in Chapter 6. This study presents the developmental process, integrating insights from literature, stakeholders, and theoretical concepts into specific interventions components. In this chapter first reflections on the acceptability of the intervention materials from the view of users are presented as well.

The study presented in Chapter 7 describes the content of ACP conversations conducted by trained clinicians based on IMPACT and provides insight in the way clinicians document these conversations in medical records.

In Chapter 8, the experiences of clinicians and families with ACP conversations based on IMPACT are described.

Chapter 9 entails the general discussion, which reflects on experiences within the developmental process and the pilot phase of IMPACT. In this chapter the strengths and limitations of this research project are reported. Recommendations for future research are included and a final conclusion summarizes the insights gained during this research project in the field of pediatric $\mathrm{ACP}$.

\section{References}

1. Feudtner C, Tammy I, Hexem KR, et al. Pediatric Palliative Care Patients: A Prospective Multicenter Cohort Study. Pediatrics. 2011;127:1094-1101.

2. Fraser ALK, Miller M, Hain R, et al. Rising National Prevalence of Life-Limiting Conditions in Children in England. Pediatrics. 2012;129(4):e923-e929. 
3. ACT. A Guide to the Development of Children's Palliative Care Services. Third Edit. Bristol, UK, 2009.

4. Commissie Bekostiging Intensieve Kindzorg (BIKZ). Rapport Bekostiging Intensieve Zorg (Dutch Publication); 2010.

5. Molenkamp C, Abu-Saad H HJ. Paediatric Palliative Care in the Netherlands (Dutch publication). Maastricht: Maastricht University; 2012.

6. Cohen E, Berry JG, Camacho X, Anderson G, Wodchis W, Guttmann A. Patterns and costs of health care use of children with medical complexity. Pediatrics. 2012;130(6).

7. Simon TD, Berry J, Feudtner $C$, et al. Children with complex chronic conditions in inpatient hospital settings in the United States. Pediatrics. 2010;126(4):647-655.

8. Waldman E, Wolfe J. Palliative care for children with cancer. Nat Rev Clin Oncol. 2013;10(2):86-93.

9. Verberne LM, Kars MC, Schouten-van Meeteren AYN, et al. Aims and tasks in parental caregiving for children receiving palliative care at home: a qualitative study. Eur J Pediatr. 2017;176(3):343-354.

10. Verberne LM, Kars MC, Schouten-van Meeteren AYN, et al. Parental experiences and coping strategies when caring for a child receiving paediatric palliative care: a qualitative study. Eur J Pediatr. 2019 Jul;178(7):1075-1085

11. Wharton RH, Levine KR, Buka S, Emanuel L. Advance care planning for children with special health care needs: a survey of parental attitudes. Pediatrics. 1996;97(5):682-687.

12. Levine DR, Mandrell BN, Sykes A, et al. Patients' and parents' needs, attitudes, and perceptions about early palliative care integration in pediatric oncology. JAMA Oncol. 2017;3(9):1214-1220.

13. WHO Definition of Palliative Care. Published 1998. https://www.who.int/cancer/palliative/definition/en/ (accessed 15 May 2020) 
14. Kenniscentrum Kinderpalliatieve zorg. https://www.kinderpalliatief.nl. (accessed 14 May 2020)

15. Knops RRG, Kremer LCM, Verhagen AAE. Paediatric palliative care: Recommendations for treatment of symptoms in the Netherlands Palliative care in other conditions. BMC Palliat Care. 2015;14(1):1-8.

16. Feudtner $C$, Rosenberg AR, Boss RD, et al. Challenges and Priorities for Pediatric Palliative Care Research in the U.S. and Similar Practice Settings: Report From a Pediatric Palliative Care Research Network Workshop. J Pain Symptom Manage. 2019;58(5):909-917.e3.

17. Dreesens D, Veul L, Westermann J, et al. The clinical practice guideline palliative care for children and other strategies to enhance shared decision-making in pediatric palliative care; pediatricians' critical reflections. BMC Pediatr. 2019;19(1):1-11.

18. Orkin J, Beaune $\mathrm{L}$, Moore $\mathrm{C}$, et al. Toward an understanding of advance care planning in children with medical complexity. Pediatrics. 2020 Mar;145(3):e20192241

19. Kars M, Grypdocnk M, Van Delden J. Being a Parent of a Child With Cancer Throughout the End-of-Life Course. Oncol Nurs Forum. 2011;38(4):2011.

20. Thienprayoon R, Alessandrini E, Frimpong-Manso M, Grossoehme D. Defining ProviderPrioritized Domains of Quality in Pediatric Home-Based Hospice and Palliative Care: A Study of the Ohio Pediatric Palliative Care and End-of-Life Network. J Palliat Med. 2018;21(10):1414-1435.

21. Håkansson Eklund J, Holmström IK, Kumlin T, et al. "Same same or different?" A review of reviews of person-centered and patient-centered care. Patient Educ Couns. 2019;102(1):311.

22. Morgan S, Yoder LH. A Concept Analysis of Person-Centered Care. J Holist Nurs. 2012;30(1):6-15.

23. Tomaselli G, Buttigieg SC, Rosano A, Cassar M, Grima G. Person-Centered Care From a 
Relational Ethics Perspective for the Delivery of High Quality and Safe Healthcare: A Scoping Review. Front Public Heal. 2020;8(March):1-11.

24. WHO Constitution. https://www.who.int/about/who-we-are/constitution (accessed 15 May 2020)

25. Huber M, André Knottnerus J, Green L, et al. How should we define health? BMJ. 2011;343(7817):1-3.

26. Santoro JD, Bennett M. Ethics of end of life decisions in pediatrics: A narrative review of the roles of caregivers, shared decision-making, and patient centered values. Behav Sci (Basel). 2018 Apr 26;8(5):42.

27. Hein IM, Troost PW, Broersma A, Vries MC De, Daams JG, Lindauer RJL. Why is it hard to make progress in assessing children's decision-making competence? BMC Med Ethics. 2015;16(1):1-6.

28. Hughes B, O'Brien MR, Flynn A, Knighting K. The engagement of young people in their own advance care planning process: A systematic narrative synthesis. Palliat Med. 2018;32(7):1147-1166.

29. Feenstra B, Boland L, Lawson ML, et al. Interventions to support children's engagement in health-related decisions: a systematic review. BMC Pediatr. 2014;14:109.

30. Kars MC, Grypdonck MHF, de Bock LC, van Delden JJM. The parents' ability to attend to the "voice of their child" with incurable cancer during the palliative phase. Heal Psychol. 2015;34(4):446-452.

31. Lozano P, Houtrow A. Supporting self-management in children and adolescents with complex chronic conditions. Pediatrics. 2018;141:S233-S241.

32. Lindemann H. Why families matter. Pediatrics. 2014;134(October):S97-S103.

33. Rietjens JAC, Sudore PRL, Connolly M, et al. Review Definition and recommendations for advance care planning: an international consensus supported by the European 
Association for Palliative Care. Lancet Oncol. 2017;18(9):e543-e551.

34. Teno JM, Licks S, Wenger N, Connors AF, Phillips RS, Connor MAO. Do advance directives provide instructions that direct care? SUPPORT Investigators. Study to Understand Prognoses and Preferences for Outcomes and Risks of Treatment. J Am Geriatr Soc. 1997;45(4):508-512.

35. Covinsky KE, Fuller JD, Yaffe K, et al. Communication and decision-making in seriously ill patients: findings of the SUPPORT project. The Study to Understand Prognoses and Preferences for Outcomes and Risks of Treatments. J Am Geriatr Soc. 2000;48(5):S187S193.

36. Brinkman-Stoppelenburg A, Rietjens JAC, van der Heide A. The effects of advance care planning on end-of-life care: A systematic review. Palliat Med. 2014;28(8):1000-1025.

37. Myers J, Cosby R, Gzik D, et al. Provider Tools for Advance Care Planning and Goals of Care Discussion: A Systematic Review. Am J Hosp Palliat Med. 2018;35(8):1123-1132.

38. DeCourcey DD, Silverman M, Oladunjoye A, Wolfe J. Advance Care Planning and ParentReported End-of-Life Outcomes in Children, Adolescents, and Young Adults With Complex Chronic Conditions. Crit Care Med. 2019;47(1):101-108.

39. Lotz JD, Jox RJ, Borasio GD, Fuhrer M. Pediatric advance care planning from the perspective of health care professionals: A qualitative interview study. Palliat Med. 2015;29(3):212-222.

40. Lotz JD, Daxer M, Jox RJ, Borasio GD, Führer M. "Hope for the best, prepare for the worst": a qualitative interview study on parents' needs and fears in pediatric advance care planning. Palliat Med. 2016;31(8):764-771.

41. Durall A, Zurakowski D, Wolfe J. Barriers to conducting advance care discussions for children with life-threatening conditions. Pediatrics. 2012;129(4):e975-82.

42. De Vleminck A, Houttekier D, Pardon K, et al. Barriers and facilitators for general 
practitioners to engage in advance care planning: A systematic review. Scand J Prim Health Care. 2013;31(4):215-226.

43. Gilissen J, Pivodic L, Smets T, et al. Preconditions for successful advance care planning in nursing homes: a systematic review. Int J Nurs Stud. 2017;66:47-59.

44. Baran CN, Sanders JJ. Communication Skills: Delivering Bad News, Conducting a Goals of Care Family Meeting, and Advance Care Planning. Prim Care - Clin Off Pract. 2019;46(3):353-372.

45. Tsai E. Canadian Paediatric Society, Bioethics Committee. Advance care planning for paediatric patients. Paediatr Child Heal. 2008;13(9):791-796.

46. American Academy of Pediatrics. Pediatric Palliative Care and Hospice Care Commitments, Guidelines, and Recommendations. Pediatrics. 2013;132:966-972.

47. End of life care for infants, children and young people with life-limiting conditions: planning and management. NICE guideline. Published 2016. nice.org.uk/guidance/ng61 (accessed January 14, 2019).

48. Lotz JD, Jox RJ, Borasio GD, Führer M. Pediatric advance care planning: a systematic review. Pediatrics. 2013;131(3):e873-e880.

49. Lewin S, Hendry M, Chandler J, et al. Assessing the complexity of interventions within systematic reviews: development, content and use of a new tool (iCAT_SR). BMC Medical Research Methodology. 2017 Apr 26;17(1):76.

50. Hoffmann TC, Oxman AD, Ioannidis JPA, et al. Enhancing the usability of systematic reviews by improving the consideration and description of interventions. BMJ. 2017;357:j2998

51. Kimmel AL, Wang J, Scott RK, Briggs L, Lyon ME. FAmily CEntered (FACE) advance care planning: Study design and methods for a patient-centered communication and decisionmaking intervention for patients with HIV/AIDS and their surrogate decision-makers. 
Contemp Clin Trials. 2015;43:172-178.

52. Lyon ME, Jacobs S, Briggs L, Cheng YI, Wang J. Family-centered advance care planning for teens with cancer. JAMA Pediatr. 2013;167(5):460-467.

53. Dallas $\mathrm{RH}$, Kimmel A, Wilkins ML, et al. Acceptability of Family-Centered Advanced Care Planning for Adolescents With HIV. Pediatrics. 2016;138(6):e20161854-e20161854.

54. Lyon ME, D'Angelo $\mathrm{L}$, Dallas $\mathrm{RH}$, et al. A randomized clinical trial of adolescents with HIV/AIDS: pediatric advance care planning. AIDS Care - Psychol Socio-Medical Asp AIDS/HIV. 2017;29(10):1287-1296.

55. Wiener L, Ballard E, Brennan T, Battles H, Martinez P, Pao M. How I wish to be remembered: the use of an advance care planning document in adolescent and young adult populations. J Palliat Med. 2008;11(10):1309-1313.

56. Wiener $\mathrm{L}$, Zadeh S, Battles $\mathrm{H}$, et al. Allowing Adolescents and Young Adults to Plan Their End-of-Life Care. Pediatrics. 2012;130(5):897-905.

57. Hammes BJ. D, Klevan J., Kempf M., Williams MS. Pediatric advance care planning. J Palliat Med. 2005;8(4):766-773.

58. Fraser J, Harris N, Berringer a J, Prescott H, Finlay F. Advanced care planning in children with life-limiting conditions - the Wishes Document. Arch Dis Child. 2010;95(2):79-82.

59. Toce S, Collins MA. The FOOTPRINTS model of pediatric palliative care. J Palliat Med. 2003;6(6):989-1000.

60. Ouchi K, Wu M, Medairos R, et al. Initiating palliative care consults for advanced dementia patients in the emergency department. J Palliat Med. 2014;17(3):346-350.

61. Finlay F, Lewis M, Lenton S, Poon M. Planning for the end of children's lives -the lifetime framework. Child Care Health Dev. 2008;34(4):542-544.

62. Loeffen EAH, Tissing WJE, Schuiling-Otten MA, De Kruiff CC, Kremer LCM, Verhagen AAE. 
Individualised advance care planning in children with life-limiting conditions. Arch Dis Child. 2018;103(5):480-485.

63. CYPACP Collaboration N. Child and Young Person's Advance Care Plan. Published online 2017. http://cypacp.uk/document-downloads/care-plan/ (accessed 15 May 2020)

64. Medical Research Council. A framework for development and RCTs for complex interventions. London Med Res Counc. 2000;(April):1-19.

http://www.mrc.ac.uk/Utilities/Documentrecord/index.htm?d=MRC003372 (accessed 15 May 2020)

65. Craig P, Dieppe P, Macintyre S, Mitchie S, Nazareth I, Petticrew M. Developing and evaluating complex interventions: The new Medical Research Council guidance. BMJ. 2008;337(7676):979-983.

66. Bleijenberg N, de Man-van Ginkel JM, Trappenburg JCA, et al. Increasing value and reducing waste by optimizing the development of complex interventions: Enriching the development phase of the Medical Research Council (MRC) Framework. Int J Nurs Stud. 2018;79(October 2017):86-93. 


\title{
Chapter 2
}

Interventions guiding Advance Care Planning conversations:

A Systematic Review

\author{
Jurrianne C. Fahner \\ Alexandra J.M. Beunders \\ Agnes van der Heide \\ Judith A.C. Rietjens \\ Maaike M. Vanderschuren \\ Johannes J.M. van Delden \\ Marijke C. Kars
}

J Am Med Dir Assoc. 2019 Mar;20(3):227-248 


\begin{abstract}
Background: Advance Care Planning (ACP) is a communicative process of defining preferences for future medical care. Conversation guides support professionals to conduct ACP conversations, yet insight in essential components is limited.

Objectives: To evaluate the content, rationale and empirical evidence on the effect of ACP interventions based on conversation guides.

Methods: Medline, Embase, PsychINFO and CINAHL were searched from January 1, 1998 to February 23, 2018 to identify peer-reviewed articles describing or evaluating ACP interventions based on scripted conversation guides. A thematic analysis of the guides was performed. Data on intervention characteristics, underlying rationale and empirical evidence were extracted by two authors independently using a pre-designed form. Assessment of risk of bias and quality of reporting was performed using COCHRANE tools and COREQ respectively.
\end{abstract}

Results: Eighty-two articles reporting on thirty-four unique interventions met the inclusion criteria. Analysis of the conversation guides revealed a framework for ACP conversations consisting of four phases: preparation, initiation, exploration and action. Exploration of patient's perspectives on illness, living well, end-of-life (EOL) issues and decision making formed the core part of the guides. Their design was often expert-based, without an underlying theoretical background. Empirical evidence on the effect of the interventions was based on heterogeneous outcome measures. Dyad congruence and preference documentation rates increased among intervention subjects in most studies. The studies showed varying effects on knowledge of ACP, decisional conflict, quality of communication and preferences-concordant care. Qualitative research showed that participants appreciate the importance and benefits of ACP conversations, yet perceive them as difficult and emotional.

Conclusion: ACP conversation guides address a diversity of themes regarding illness, EOL and decision making. There is a focus on the exploration of patient's perspectives and preferences. Evidence on the translation of explorative information into specific treatment preferences and consequences for care as provided is limited. 


\section{Introduction}

Especially in long-term care, the exploration of patients' perspectives on their illness and future medical needs is essential to provide high-quality medical care. ${ }^{1}$ Advance Care Planning (ACP) is known as a strategy to communicate about preferences for future medical care. ACP is defined by an international taskforce as follows: 'ACP enables individuals to define goals and preferences for future medical treatment and care, to discuss these goals and preferences with family and healthcare providers, and to record and review these preferences if appropriate. ${ }^{2}$ When an individual's health situation worsens, ACP can become more targeted. ${ }^{2}$ Evidence for the effects of ACP on completion of advance directives, improved patient-family concordance regarding preferences for medical care and increased congruence between preferences for care and actual received care is growing. ${ }^{3-5}$ Unfortunately, barriers such as lack of knowledge about ACP and lack of conversation skills among professionals remain., ${ }^{6,7}$ Several interventions have been developed to support health care professionals to discuss goals and preferences for future medical care in daily practice. These interventions support professionals by providing guidance to the structure and content of ACP conversations by a conversation guide. ${ }^{8}$ To our knowledge, no systematic review has been performed to provide an overview of the content of ACP conversation guides, their rationale and effectiveness so far. Such an overview would be helpful to understand how the concept of ACP is translated into actual conversations and practices and could support health care professionals to conduct ACP conversations themselves. Therefore, this review aims to 1 ) provide a narrative synthesis of the characteristics and theoretical background of interventions which incorporate an ACP conversation guide, 2) provide an analysis of the structure and content of those conversation guides and 3) summarize empirical evidence about the feasibility and effects of the interventions.

\section{Methods}

\section{Data Sources and Searches}

The Preferred Reporting Items for Systematic Reviews and Meta-Analyses (PRISMA) checklist was used to structure the review process. $^{9}$ A structured computerized literature search was performed in four databases: Medline, Embase, PsychINFO and CINAHL. The search strategy 
included terms describing the following domains: 'advance care planning', 'intervention' and 'communication'. (Table 1) Two reviewers (JF, MV) independently screened all abstracts to select relevant papers. Disagreements were resolved by discussion. Reference lists of selected studies were hand-searched for additional relevant papers (JF and KP).

\section{Study Selection}

Studies, published in English in peer-reviewed journals between 1 January 1998 and 23 February 2018 describing a structured approach of ACP conversations by providing a conversation guide with verbal examples for health care professionals were considered eligible. If the content of the conversation guide was not described in detail more information was requested by contacting the corresponding author. Potentially eligible studies were assessed full text independently by two reviewers (JF, MV). Disagreements were resolved by discussion.

\section{Table 1 Search strategy for all databases}

Search strategy for Medline

(exp "advance care planning"/ OR ((advance adj preferences) or (advance* adj3 planning) or (advance* adj2 directive*) or living will* or life-limiting or ("end-of-life" adj (care or plan* or decision*)) or "terminal care" or (future care adj3 planning)).ti,ab,kf.)

AND

(Communication/ or goals/ OR (intervention or conversation* or facilitate or approach or tool or document* or discussion* or goal* or program* or "decision aid" or communication).ti,ab,kf.)

Search strategy for Embase

('living will'/exp OR 'terminal care'/exp OR (advance NEAR/1 preferences):ti,ab, de OR (advance* NEAR/3 planning):ti,ab, de OR (advance* NEAR/2 directive*):ti,ab, de OR (living NEAR/1 will):ti,ab, de OR 'life limiting':ti,ab,de OR ('end-of-life' NEAR/1 (care OR plan* OR decision*)):ti,ab,de OR 'terminal care':ti,ab, de OR ('future care' NEAR/3 planning):ti,ab, de OR ('palliative therapy'/exp)

AND

('patient care planning'/exp) AND ('interpersonal communication'/exp OR 'goal attainment'/exp OR intervention:ti,ab, de OR conversation*:ti,ab, de OR facilitate:ti,ab,de OR approach:ti,ab, de OR tool:ti,ab, de OR document*:ti,ab, de OR discussion*:ti,ab, de OR goal*:ti,ab, de OR program*:ti,ab, de OR 'decision aid':ti,ab,de) NOT ('conference abstract'/it OR 'conference paper'/it OR 'conference review'/it OR 'review'/it) AND [embase]/lim)

Search strategy for PsychINFO

(exp Treatment Planning/ and exp Palliative Care/ or exp Palliative Care/ and exp Decision Making/ or ((advance adj preferences) or (advance* adj3 planning) or (advance* adj2 directive*) or living will* or lifelimiting or ("end-of-life" adj (care or plan* or decision*)) or "terminal care" or (future care adj3 planning)).ti,ab,id. or exp Advance Directives/) AND

(exp COMMUNICATION/ OR exp GOALS/ or (intervention or conversation* or facilitate or approach or 
tool or document* or discussion* or goal* or program or "decision aid" or communication).ti,ab,id.)

Search strategy for CINAHL

(MH "advance care planning" or (TI((advance N1 preferences) or (advance* N3 planning) or (advance* N2 directive $^{\star}$ ) or (living N1 will*) or life-limiting or ("end-of-life" N1 (care or plan*)) or "terminal care" or ("future care" N3 planning))) or (AB((advance N1 preferences) or (advance* N3 planning) or (advance* N2 directive*) or (living N1 will*) or life-limiting or ("end-of-life" N1 (care or plan*)) or "terminal care" or ("future care" N3 planning))))

AND

((MH "Goals and Objectives+") OR (MH "Goal-Setting") OR (MH "Goal Attainment") or AB(intervention or conversation* or facilitate or approach or tool or document* or discussion* or goal or program* or "decision aid" or communication) or TI(intervention or conversation* or facilitate or approach or tool or document* or discussion* or goal or program* or "decision aid" or communication) or $\mathrm{MH}$ "communication+")

Search date 23 February 2018

\section{Data Extraction and Quality Assessment}

Data extraction was performed by two reviewers (JF, AB) using a predesigned form. Characteristics of the interventions were extracted based on the Taxonomy of Schulz. ${ }^{10}$ Any theoretical background and data on feasibility and effectiveness were extracted. Two reviewers (JF, AB) performed a risk of bias assessment on the included quantitative studies. For randomized controlled trials and non-randomized controlled trials the Cochrane Bias Tool was used, evaluating random sequence generation, allocation concealment, blinding of participants, blinding of outcome assessment, incomplete outcome data and selective reporting. A score of 1 was assigned when the criterion had been met, a score of 0 when the criterion had not been met and a question mark when the information for rating the criterion was lacking. The rating resulted in a total score ranging from 0 to 6 . Observational studies were assessed in a similar way with the use of an adapted version of the Cochrane Bias tool (Appendix Table A1), assessing seven categories: selection study population, comparability of study groups, standardization intervention protocol, standardization outcome measurements, missing data, confounders, selective outcome reporting. The criteria were rated as described above and this resulted in a total score ranging from 0 to 7 . The assessment tools do not include a cutoff point for categorizing the studies based on their risk of bias. Therefore median scores with ranges are presented. The quality of reporting was assessed for qualitative studies using the COmprehensive consolidated criteria for REporting Qualitative research (COREQ). ${ }^{11,12}$ The 
checklist evaluates a total of 32 criteria on three categories: 1) research team and reflexivity, 2) study design and 3) analysis and findings. A score of 1 was assigned when the criterion had been properly described, a score of 0 when it was not described and a score of 0.5 when the description was incomplete. The rating resulted in a total score ranging from 0 to 32. Mixedmethods studies were assessed both for risk of bias and quality of reporting. Disagreements were resolved by discussion. In line with the explorative nature of this review, the quality of selected studies did not affect inclusion. ${ }^{13}$

\section{Data Synthesis and Analysis}

We analyzed the data to provide a narrative synthesis of the characteristics, conceptual background and feasibility and effectiveness of the interventions. ${ }^{14}$ The content of the conversation guides was thematically analyzed using NVivo $10 .{ }^{15}$ Open coding of the first five guides and categorization of codes resulted in an initial conceptual framework of the structure, themes and language of the conversation guides. Subsequently, guides were coded using these initial concepts and new concepts were created when deemed necessary (JF and MK). The concepts were clustered into themes. Sample statements were selected from the conversation guides to illustrate the themes.

\section{Results}

The search yielded 15745 unique hits. Eighty-two articles met the inclusion criteria (Figure 1) reporting on 34 unique ACP interventions. Sixty-one articles presented empirical data about 27

interventions. ${ }^{16-76}$ The remaining articles presented a description of the intervention or a study protocol. $^{7,77-96}$ 
Figure 1. PRISMA Flow Diagram of Literature Review Process

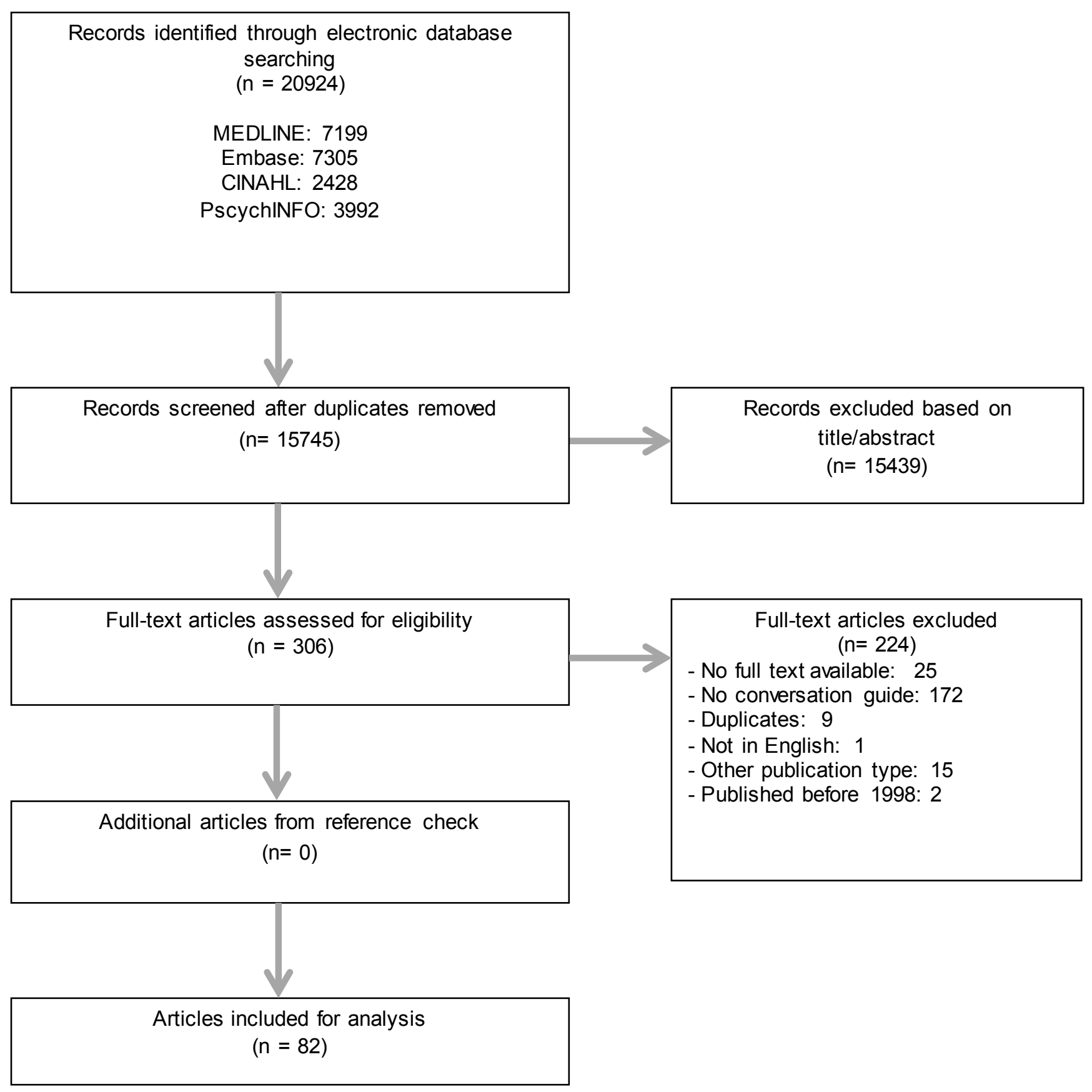




\section{Risk of Bias and Quality of reporting}

A detailed overview of the risk of bias assessment and quality of reporting assessment underlying the total scores is presented in the Appendix Table A2-A6. The total scores for each study are presented in Table 4-6. For RCT's $(n=21)$ and non-randomized controlled trials $(n=3)$ the median total score of sufficiently met criteria was 3 (range 0-4) (Table 4). No trial met the criterion of blinding of participants. For observational studies $(n=13)$ and the quantitative part of mixed-method studies $(n=11)$ ) the median total score of sufficiently met criteria was 3 (range 1-5) (Table 5) and 1 (range 0-3) (Table 6) respectively. The assessment showed a low risk of bias regarding standardization of the $A C P$ intervention ${ }^{20,22,23,28,36,42,49,61-63,74}$ and standardization of outcome measurement in most studies. ${ }^{16,23,28,36,42-44,48,59-62,74,75}$ For qualitative studies $(\mathrm{n}=13)$ an assessment of the quality of reporting showed a median total score of sufficiently met criteria of 16.5 (range 12.5-29). (Appendix Table A7) For mixed-methods studies $(n=11)$ the median total score of sufficiently met criteria was 15 (range 3-18.5).

\section{Intervention characteristics}

The 34 interventions were numbered and their characteristics summarized in Table 2. In general, two different designs of conversation guides were identified. About two-thirds of the interventions provided an exact scripted conversation guide. (Intervention:1,2,4,5,7,9,12,13,14,17,18,21,22,24-31,33) The other one-third provided guidance to the conversation by suggesting topics and prompts, but in a less structured format. (Intervention:3,6,8,10,11,15,16,19,20,23,32,34)

Most identified interventions were developed for or tested in populations with serious illnesses. (Intervention:1-3,6,7,11-16,18,20-23,25-29,32,34) In some interventions involvement of a surrogate decision maker was an essential part of the intervention. (Intervention:2,4,6,13,25,27,29,33) Others left the decision to include a proxy to the patient. The interventionists had a broad range of professions including physicians, nurses, social workers, patient navigators and psychologists. Most interventions provided educational materials for the health care professional, the patient and family or both. In about half of the interventions, some 
form of training of the interventionist was included, ranging from a couple of hours to multiple day courses.

\section{Theoretical background}

Most articles reported on the development of the intervention which could involve a review of literature, expert panels with professionals and patients, and pilot testing. ${ }^{79-22,26,29,38,39,41-47,63,71-}$ $73,79,80,84,91,92,94,95$ A description of a theoretical background was often absent. ${ }^{7,16,19-21,26,38,41,43-}$ $45,63,71,73,79,80,91,95,96$

Basic ethical principles were described by some authors as background for their intervention. Some stated that the ethical principle of patient autonomy played a central role in Advance Care Planning originally, but that principles of communication and relational ethics had been introduced, focusing on a deeper conversation between the patient and healthcare professionals to identify and respect values of the patient and his psychosocial context. ${ }^{17,18,39,78}$ Two authors used the concept of meaning-searching activities and legacy-making in the intervention. ${ }^{40,46}$ Others used the concept of motivational interviewing as a background for the design of the conversation guide. ${ }^{42,72}$

Six interventions (Intervention:6,13,24,25,28,31) were based on the representational approach of patient education. This theory is based on the Leventhal's description of illness along five identities (illness identity, cause, time line, consequences and cure/control) and the conceptual change model. ${ }^{97}$ Based on this theory, exploration of patient's perspectives on ACP-themes and provision of patient-tailored information form the key steps in the conversation, resulting in highly individualized patient-specific processes. 
Table 2. Overview characteristics and available evidence

\begin{tabular}{|c|c|c|c|c|c|c|c|c|}
\hline \multirow{2}{*}{$\begin{array}{l}\text { Intervention } \\
\text { (Country) } \\
\text { Accessibility }\end{array}$} & \multicolumn{5}{|c|}{ Characteristics intervention } & \multicolumn{3}{|c|}{ Included publications } \\
\hline & $\begin{array}{l}\text { Mode, schedule } \\
\text { and setting }\end{array}$ & Target Population & Interventionist & $\begin{array}{l}\text { Scripting and } \\
\text { materials }\end{array}$ & $\begin{array}{l}\text { Treatment } \\
\text { implementation }\end{array}$ & $\begin{array}{l}\text { Description } \\
\text { intervention }\end{array}$ & $\begin{array}{l}\text { Feasibility } \\
\text { outcomes }\end{array}$ & $\begin{array}{l}\text { Effect } \\
\text { outcomes }\end{array}$ \\
\hline $\begin{array}{l}\text { I1. ACP for adults with } \\
\text { congenital/pediatric heart } \\
\text { disease } \\
\text { (USA) } \\
\text { Guide included in article }^{16}\end{array}$ & $\begin{array}{l}\text { Face-to-face } \\
\text { conversation at } \\
\text { heart failure and } \\
\text { transplant clinic }\end{array}$ & $\begin{array}{l}\text { Patients } \geq 18 \text { years } \\
\text { with } \\
\text { congenital/pediatric } \\
\text { heart disease }\end{array}$ & $\begin{array}{l}\text { Transplant and } \\
\text { cardiomyopathy } \\
\text { coordinators }\end{array}$ & $\begin{array}{l}\text { - Exact } \\
\text { scripted } \\
\text { conversation } \\
\text { guide } \\
\text { - Patient } \\
\text { information } \\
\text { folders } \\
\text { - Pre visit } \\
\text { provision of } \\
\text { Voicing My } \\
\text { Choices } \\
\text { - } \\
\text { Documentation } \\
\text { format in EHR }\end{array}$ & $\begin{array}{l}\text { Documented } \\
A D\end{array}$ & & & $\begin{array}{l}\text { Edwards } \\
2018^{16}\end{array}$ \\
\hline $\begin{array}{l}\text { 12. ACP by general } \\
\text { practitioners } \\
\text { (Belgium) } \\
\text { Guide available fromauthor }{ }^{7}\end{array}$ & $\begin{array}{l}\text { Face-to-face } \\
\text { conversation in } \\
\text { general practice }\end{array}$ & $\begin{array}{l}\text { Patients at risk of } \\
\text { deteriorating or } \\
\text { dying }\end{array}$ & $\begin{array}{l}\text { General } \\
\text { practitioner } \\
\text { (2hr training } \\
\text { program) }\end{array}$ & $\begin{array}{l}\text { - Exact } \\
\text { scripted } \\
\text { conversation } \\
\text { guide } \\
\text { - Educational } \\
\text { materials GP's } \\
\text { - Register } \\
\text { eligible } \\
\text { patients } \\
\text { - Educational } \\
\text { booklet } \\
\text { patients } \\
\text { - } \\
\text { Documentation } \\
\text { template }\end{array}$ & $\begin{array}{l}\text { - Template for } \\
\text { documentation } \\
\text { of the } \\
\text { discussion } \\
\text { - GP's } \\
\text { encourage } \\
\text { patient to share } \\
\text { document with } \\
\text { other health } \\
\text { care providers }\end{array}$ & $\begin{array}{l}\text { DeVlemick } \\
2016^{7}\end{array}$ & & \\
\hline $\begin{array}{l}\text { I3. ACP in COPD } \\
\text { (Canada) } \\
\text { Guide as appendix }^{17}\end{array}$ & $\begin{array}{l}\text { Double session } \\
\text { face-to-face } \\
\text { conversation at } \\
\text { home }\end{array}$ & $\begin{array}{l}\text { Patients with } \\
\text { advanced } \\
\text { COPD and their } \\
\text { informal care } \\
\text { givers }\end{array}$ & $\begin{array}{l}\text { Facilitator } \\
\text { (trained) }\end{array}$ & $\begin{array}{l}\text { - Conversation } \\
\text { guide with } \\
\text { question } \\
\text { examples } \\
\text { - Booklet for } \\
\text { patients }\end{array}$ & $\begin{array}{l}\text { Completion of } \\
\text { advance } \\
\text { directive }\end{array}$ & & $\begin{array}{l}\text { Simpson } \\
2011^{17} \\
\text { Simpson } \\
2012^{18}\end{array}$ & $\begin{array}{l}\text { Simpson } \\
2011^{17} \\
\text { Simpson } \\
2012^{18}\end{array}$ \\
\hline
\end{tabular}




\begin{tabular}{|c|c|c|c|c|c|c|c|c|}
\hline $\begin{array}{l}\text { I4. ACP in early dementia } \\
\text { (UK) } \\
\text { Guide as appendix }^{19}\end{array}$ & $\begin{array}{l}\text { Face-to-face } \\
\text { conversation at } \\
\text { Memory service } \\
\text { clinic }\end{array}$ & $\begin{array}{l}\text { Patients with early } \\
\text { (mild) dementia } \\
\text { and their carers }\end{array}$ & $\begin{array}{l}\text { Senior nurse } \\
\text { and clinical } \\
\text { psychologist }\end{array}$ & $\begin{array}{l}\text { - Exact } \\
\text { scripted } \\
\text { conversation } \\
\text { guide, also } \\
\text { used for } \\
\text { documentation } \\
\text { - Training } \\
\text { package for } \\
\text { staff }\end{array}$ & $\begin{array}{l}\text { Authors } \\
\text { emphasize } \\
\text { need to make } \\
\text { ACP- } \\
\text { documentation } \\
\text { available to } \\
\text { other health } \\
\text { care providers }\end{array}$ & & $\begin{array}{l}\text { Poppe } \\
2013^{19}\end{array}$ & $\begin{array}{l}\text { Poppe } \\
2013^{19}\end{array}$ \\
\hline $\begin{array}{l}\text { 15. ACP in geriatric } \\
\text { patients } \\
\text { (Norway) } \\
\text { Guide included in article }\end{array}$ & $\begin{array}{l}\text { Single bedside } \\
\text { face-to-face } \\
\text { conversation } \\
\text { at geriatric ward }\end{array}$ & $\begin{array}{l}\text { Patients admitted } \\
\text { to geriatric } \\
\text { hospital ward }\end{array}$ & $\begin{array}{l}\text { Senior } \\
\text { consultant of } \\
\text { geriatric } \\
\text { department }\end{array}$ & $\begin{array}{l}\text { Exact scripted } \\
\text { conversation } \\
\text { guide }\end{array}$ & NS & & $\begin{array}{l}\text { Friis } \\
2015^{20}\end{array}$ & $\begin{array}{l}\text { Friis } \\
2015^{20}\end{array}$ \\
\hline $\begin{array}{l}\text { I6. ACP in patients with } \\
\text { Chronic Kidney } \\
\text { disease } \\
\text { (Canada) } \\
\text { Guide as appendix }^{77}\end{array}$ & $\begin{array}{l}\text { Face-to-face } \\
\text { conversation } \\
\text { included in } \\
\text { university- } \\
\text { based renal } \\
\text { Program }\end{array}$ & $\begin{array}{l}\text { Adults with End } \\
\text { Stage } \\
\text { Renal Disease and } \\
\text { surrogates }\end{array}$ & $\begin{array}{l}\text { Social workers } \\
\text { and } \\
\text { nephrologists, } \\
\text { preferably } \\
\text { trained }\end{array}$ & $\begin{array}{l}\text { Conversation } \\
\text { guide with } \\
\text { question } \\
\text { examples }\end{array}$ & $\begin{array}{l}\text { Documentation } \\
\text { of ACP- } \\
\text { process } \\
\text { in dialysis } \\
\text { medical record }\end{array}$ & $\begin{array}{l}\text { Davison } \\
2007^{77} \\
\text { Davison } \\
2012^{76}\end{array}$ & & \\
\hline $\begin{array}{l}\text { I7. ACP for patients with } \\
\text { inoperable } \\
\text { lung cancer }^{\text {a }} \\
\text { (UK) } \\
\text { Guide partial available in article }\end{array}$ & $\begin{array}{l}\text { Face-to-face } \\
\text { conversation at } \\
\text { outpatient clinic }\end{array}$ & $\begin{array}{l}\text { Patients with } \\
\text { inoperable } \\
\text { lung cancer }\end{array}$ & $\begin{array}{l}\text { Lung cancer } \\
\text { nurses }\end{array}$ & $\begin{array}{l}\text { - Exact } \\
\text { scripted } \\
\text { conversation } \\
\text { guide } \\
\text { - Letter to } \\
\text { record } \\
\text { discussion } \\
\text { - Checklist to } \\
\text { clarify content } \\
\text { of ACP record } \\
\text { with patients }\end{array}$ & $\begin{array}{l}\text { GP clinic } \\
\text { letter to record } \\
\text { ACP } \\
\text { discussion }\end{array}$ & & $\begin{array}{l}\text { Horne } \\
2006^{21}\end{array}$ & $\begin{array}{l}\text { Horne } \\
2006^{21}\end{array}$ \\
\hline $\begin{array}{l}\text { 18. ACP Group Medical } \\
\text { Visit } \\
\text { (USA) } \\
\text { Guide included in article }^{22}\end{array}$ & $\begin{array}{l}\text { Two group } \\
\text { sessions of } 2 \\
\text { hours each, } 1 \\
\text { month apart at } \\
\text { Senior Clinic }\end{array}$ & $\begin{array}{l}\text { Geriatric patients } \\
(\text { age }>65) \\
\text { receiving care at } \\
\text { primary care clinic }\end{array}$ & $\begin{array}{l}\text { Geriatrician and } \\
\text { social worker }\end{array}$ & $\begin{array}{l}\text { - Conversation } \\
\text { guide with } \\
\text { question } \\
\text { examples } \\
\text { - Educational } \\
\text { materials } \\
\text { (handout, } \\
\text { video, AD } \\
\text { template) }\end{array}$ & $\begin{array}{l}\text { - Update AD or } \\
\text { medical orders } \\
\text { as needed } \\
\text { - } \\
\text { Communication } \\
\text { preferences to } \\
\text { primary care } \\
\text { provider }\end{array}$ & & $\begin{array}{l}\text { Lum } \\
2016^{22} \\
\text { Lum }_{2017^{23}}\end{array}$ & $\begin{array}{l}\text { Lum } \\
2016^{22} \\
\operatorname{Lum}_{2017^{23}}\end{array}$ \\
\hline
\end{tabular}




\begin{tabular}{|c|c|c|c|c|c|c|c|c|}
\hline $\begin{array}{l}\text { 19. Advance Directive in } \\
\text { Two Questions } \\
\text { (USA) } \\
\text { Guide included in article }^{78}\end{array}$ & $\begin{array}{l}\text { Face-to-face } \\
\text { conversation in } \\
\text { any health care } \\
\text { setting }\end{array}$ & Any patient & $\begin{array}{l}\text { Any health care } \\
\text { professional }\end{array}$ & $\begin{array}{l}\text { Two scripted } \\
\text { questions as } \\
\text { base for } \\
\text { discussion }\end{array}$ & $\begin{array}{l}\text { Preferences } \\
\text { described in } \\
\text { short } \\
\text { document, } \\
\text { copies for } \\
\text { patient, chart } \\
\text { and palliative } \\
\text { care team }\end{array}$ & $\begin{array}{l}\text { Mahon } \\
2012^{78}\end{array}$ & & \\
\hline $\begin{array}{l}\text { I10. Communication } \\
\text { about EOL care among } \\
\text { patients with COPD } \\
\text { (USA) } \\
\text { Guide partial available in article } \\
\text { and fromauthor }{ }^{24}\end{array}$ & $\begin{array}{l}\text { Face-to-face } \\
\text { conversation } \\
\text { based on } \\
\text { patient-specific } \\
\text { feedback } \\
\text { form generated } \\
\text { by a patient- } \\
\text { reported } \\
\text { computerized } \\
\text { process at } \\
\text { regular visits at } \\
\text { outpatient clinic }\end{array}$ & $\begin{array}{l}\text { Patients with } \\
\text { COPD }\end{array}$ & Clinicians & $\begin{array}{l}\text { Clinician } \\
\text { Feedback } \\
\text { report with } \\
\text { patient specific } \\
\text { discussion } \\
\text { topics and } \\
\text { suggested } \\
\text { scripts }\end{array}$ & $\begin{array}{l}\text { Feedback form } \\
\text { was send to } \\
\text { clinician and } \\
\text { patient }\end{array}$ & & Au $2012^{<4}$ & $\begin{array}{l}\text { Au } 2012^{24} \\
\text { Reinke } \\
2017^{25}\end{array}$ \\
\hline $\begin{array}{l}\text { I11. Communication in } \\
\text { life-limiting illness } \\
\text { (USA) } \\
\text { Guide included in article }^{80}\end{array}$ & $\begin{array}{l}\text { Single or } \\
\text { multiple face-to- } \\
\text { face } \\
\text { conversation } \\
\text { preferable in } \\
\text { outpatient } \\
\text { setting, } \\
\text { but can be in } \\
\text { hospital as well }\end{array}$ & $\begin{array}{l}\text { Patients with life- } \\
\text { limiting } \\
\text { illness }\end{array}$ & Clinicians & $\begin{array}{l}\text { Conversation } \\
\text { guide with } \\
\text { examples of } \\
\text { questions }\end{array}$ & $\begin{array}{l}\text { Authors } \\
\text { emphasize } \\
\text { need to record } \\
\text { ACP } \\
\text { conversations } \\
\text { in the patient } \\
\text { chart and to } \\
\text { include a copy } \\
\text { of any } \\
\text { completed } \\
\text { documents }\end{array}$ & $\begin{array}{l}\text { Pearce } \\
2016^{80}\end{array}$ & & \\
\hline $\begin{array}{l}\text { I12. End of Life } \\
\text { Preferences Interview } \\
\text { (Italy) } \\
\text { Guide as appendix }^{26}\end{array}$ & $\begin{array}{l}\text { Single or } \\
\text { multiple session } \\
\text { face-to-face } \\
\text { conversation in } \\
\text { palliative } \\
\text { (home) care } \\
\text { centers }\end{array}$ & $\begin{array}{l}\text { Patients in } \\
\text { palliative care (23) } \\
\text { Advanced cancer } \\
\text { patients in } \\
\text { palliative care (24) }\end{array}$ & $\begin{array}{l}\text { Physicians } \\
\text { palliative care } \\
\text { centers } \\
\text { (1 day of } \\
\text { training) (24) }\end{array}$ & $\begin{array}{l}\text { - Exact } \\
\text { scripted } \\
\text { conversation } \\
\text { guide } \\
\text { - Manual for } \\
\text { interventionist }\end{array}$ & $\begin{array}{l}\text { Documentation } \\
\text { based on } \\
\text { interview } \\
\text { format }\end{array}$ & & $\begin{array}{l}\text { Borreani } \\
2008^{26} \\
\text { Borreani } \\
2012^{27}\end{array}$ & \\
\hline
\end{tabular}




\begin{tabular}{|c|c|c|c|c|c|c|c|c|}
\hline $\begin{array}{l}\text { I13. Family/Adolescents - } \\
\text { Centered (FACE) ACP } \\
\text { intervention } \\
\text { (USA) } \\
\text { Copyrighted: guide based on } 125, \\
\text { guide partial available in article }\end{array}$ & $\begin{array}{l}\text { Three session } \\
\text { face-to-face } \\
\text { conversation, } \\
\text { one week apart } \\
\text { at outpatient } \\
\text { clinic }\end{array}$ & $\begin{array}{l}\text { - Adolescents with } \\
\text { cancer and their } \\
\text { surrogate } 27,32,33 \\
\text { - Adolescents with } \\
\text { HIVIAIDS and their } \\
\text { surrogate }^{28,29,30,31,36}\end{array}$ & $\begin{array}{l}\text { A certified } \\
\text { Respecting } \\
\text { Choices } \\
\text { Facilitator }\end{array}$ & $\begin{array}{l}\text { - Exact } \\
\text { scripted } \\
\text { conversation } \\
\text { guide } \\
\text { - Readiness } \\
\text { survey } \\
\text { - AD: Five } \\
\text { Wishes } \\
\text { - Information } \\
\text { brochure about } \\
\text { ACP for } \\
\text { participants }\end{array}$ & $\begin{array}{l}\text { Completion of } \\
A D\end{array}$ & $\begin{array}{l}\text { Dallas } \\
2012^{81, b} \\
\text { Kimmel } \\
2015^{82, b} \\
\text { Curtin } \\
2017^{83, b}\end{array}$ & $\begin{array}{l}\text { Jacobs } \\
2015^{28} \\
\text { Lyon }^{2009^{29}} \\
200{ }^{2} \\
\text { Lyon }_{2013^{33}} \\
\text { Dallas } \\
2016^{37} \\
\text { Lyon }_{2017^{35}} \\
\text { Lyon }_{2017^{36}}\end{array}$ & $\begin{array}{l}\text { Lyon } \\
2009^{29} \\
\text { Lyon } \\
2009^{30} \\
\text { Lyon } \\
2010^{31} \\
\text { Lyon } \\
2011^{32} \\
\text { Lyon } \\
2013^{33} \\
\text { Lyon } \\
2014^{34} \\
\text { Dallas } \\
2016^{37} \\
\text { Lyon } \\
2017^{35} \\
\text { Lyon } \\
2017^{36}\end{array}$ \\
\hline $\begin{array}{l}\text { I14. Goals of Care } \\
\text { Communication Guide } \\
\text { (USA) } \\
\text { Guide included in article }^{38}\end{array}$ & $\begin{array}{l}\text { Face-to-face } \\
\text { conversation } \\
\text { in outpatient } \\
\text { setting or at } \\
\text { home }\end{array}$ & Serious ill patients & $\begin{array}{l}\text { Nurse and } \\
\text { social worker }\end{array}$ & $\begin{array}{l}\text { - Exact } \\
\text { scripted } \\
\text { conversation } \\
\text { guide and } \\
\text { documentation } \\
\text { form }\end{array}$ & $\begin{array}{l}\text { Completion of } \\
\text { written } \\
\text { document }\end{array}$ & & $\begin{array}{l}\text { Bekelman } \\
2017^{38}\end{array}$ & \\
\hline $\begin{array}{l}\text { I15. Heart Failure End of } \\
\text { Life Discussion } \\
\text { intervention } \\
\text { (USA) } \\
\text { Guide included in article } \\
84\end{array}$ & $\begin{array}{l}\text { Face-to-face } \\
\text { conversation }\end{array}$ & $\begin{array}{l}\text { African Americans } \\
\text { with heart failure }\end{array}$ & Nurse & $\begin{array}{l}\text { - Conversation } \\
\text { guide with } \\
\text { question } \\
\text { examples } \\
\text { - Trajectory } \\
\text { graph } \\
\text { - Conversation } \\
\text { Ready } \\
\text { pamphlet } \\
\text { - Preferences } \\
\text { form }\end{array}$ & $\begin{array}{l}\text { Completion of } \\
\text { written } \\
\text { document }\end{array}$ & $\begin{array}{l}\text { Piamiariyakul } \\
2017^{84}\end{array}$ & & \\
\hline
\end{tabular}




\begin{tabular}{|c|c|c|c|c|c|c|c|c|}
\hline $\begin{array}{l}\text { I16. Kitchen Table } \\
\text { Discussion } \\
\text { (USA) } \\
\text { Guide included in article }\end{array}$ & $\begin{array}{l}\text { Single or } \\
\text { multiple session } \\
\text { face-to-face } \\
\text { conversation at } \\
\text { home }\end{array}$ & $\begin{array}{l}\text { - Serious ill } \\
\text { patients } \\
\text { - Patients with life- } \\
\text { limiting illness } \\
\text { receiving home } \\
\text { care }\end{array}$ & $\begin{array}{l}\text { Home care and } \\
\text { hospice } \\
\text { nurses }^{38} \\
\text { Social worker }^{84}\end{array}$ & $\begin{array}{l}\text { - Conversation } \\
\text { guide with } \\
\text { question } \\
\text { examples } \\
\text { - Guide used } \\
\text { as assessment } \\
\text { form for } \\
\text { documentation }\end{array}$ & $\begin{array}{l}\text { Assessment } \\
\text { form in } \\
\text { medical record } \\
\text { and send to } \\
\text { home care } \\
\text { nurse and } \\
\text { attending } \\
\text { physician }\end{array}$ & $\begin{array}{l}\text { Norlander } \\
2000^{85}\end{array}$ & $\begin{array}{l}\text { Ratner } \\
2001^{39}\end{array}$ & $\begin{array}{l}\text { Ratner } \\
2001^{39}\end{array}$ \\
\hline $\begin{array}{l}\text { I17. Let me Talk } \\
\text { (China) } \\
\text { Guide available fromauthor }{ }^{40}\end{array}$ & $\begin{array}{l}\text { Single or } \\
\text { multiple session } \\
\text { face-to-face } \\
\text { conversation } \\
\text { and a family } \\
\text { conference at a } \\
\text { nursing home }\end{array}$ & $\begin{array}{l}\text { Frail but competent } \\
\text { nursing home } \\
\text { residents }\end{array}$ & Nurse facilitator & $\begin{array}{l}\text { - Exact } \\
\text { scripted } \\
\text { conversation } \\
\text { guide } \\
\text { - Information } \\
\text { leaflet for } \\
\text { residents } \\
\text { - Template for } \\
\text { personal } \\
\text { booklet }\end{array}$ & $\begin{array}{l}\text { Personal } \\
\text { booklet } \\
\text { summarizing } \\
\text { life stories and } \\
\text { preferences for } \\
\text { care }\end{array}$ & & $\begin{array}{l}\text { Chan } \\
2010^{40}\end{array}$ & $\begin{array}{l}\text { Chan } \\
2010^{40}\end{array}$ \\
\hline $\begin{array}{l}\text { l18. Living Well Interview } \\
\text { (USA) } \\
\text { Guide included in article }\end{array}$ & $\begin{array}{l}\text { Single session } \\
\text { face-to-face } \\
\text { conversation at } \\
\text { chemotherapy } \\
\text { ward }\end{array}$ & $\begin{array}{l}\text { Patients with } \\
\text { recent } \\
\text { diagnosis of life- } \\
\text { limiting } \\
\text { disease/terminally } \\
\text { ill patients }\end{array}$ & $\begin{array}{l}\text { Oncology nurse } \\
\text { (well-trained) }\end{array}$ & $\begin{array}{l}\text { Exact scripted } \\
\text { conversation } \\
\text { guide }\end{array}$ & & & $\begin{array}{l}\text { Schwartz } \\
2003^{41}\end{array}$ & \\
\hline $\begin{array}{l}\text { I19. Motivational Stage- } \\
\text { Tailored Intervention to } \\
\text { ACP } \\
\text { (USA) } \\
\text { Guide available fromauthor }{ }^{42}\end{array}$ & $\begin{array}{l}\text { Single session } \\
\text { face-to-face } \\
\text { conversation at } \\
\text { supportive } \\
\text { housing } \\
\text { facility }\end{array}$ & $\begin{array}{l}\text { Low-income older } \\
\text { adults living in a } \\
\text { supportive housing } \\
\text { facility }\end{array}$ & $\begin{array}{l}\text { Social work } \\
\text { graduate } \\
\text { research } \\
\text { assistant } \\
\text { (45 hours of } \\
\text { training) }\end{array}$ & $\begin{array}{l}\text { - Conversation } \\
\text { guide with } \\
\text { question } \\
\text { examples } \\
\text { - California AD } \\
\text { form } \\
\text { - Training } \\
\text { manual }\end{array}$ & $\begin{array}{l}\text { Completion of } \\
A D \text { form }\end{array}$ & & Ko $2016^{42}$ & Ko $2016^{42}$ \\
\hline $\begin{array}{l}\text { I20. Palliative Care } \\
\text { Program } \\
\text { (China) } \\
\text { Guide as appendix }\end{array}$ & $\begin{array}{l}\text { Weekly face-to- } \\
\text { face } \\
\text { conversations } \\
\text { at home, part of } \\
\text { an eight week } \\
\text { program }\end{array}$ & $\begin{array}{l}\text { Home care } \\
\text { patients with life- } \\
\text { limiting disease }\end{array}$ & $\begin{array}{l}\text { Trained nurse } \\
\text { facilitators/home } \\
\text { care providers } \\
\text { ( } 2 \text { days of } \\
\text { training) }\end{array}$ & $\begin{array}{l}\text { - Conversation } \\
\text { guide with } \\
\text { question } \\
\text { examples } \\
\text { - Educational } \\
\text { materials }\end{array}$ & $\begin{array}{l}\text { Completion of } \\
\text { DNR order }\end{array}$ & & $\begin{array}{l}\text { Chan } \\
2014^{43}\end{array}$ & $\begin{array}{l}\text { Chan } \\
2014^{43}\end{array}$ \\
\hline
\end{tabular}




\begin{tabular}{|c|c|c|c|c|c|c|c|c|}
\hline $\begin{array}{l}\text { I21. Patient Preferences } \\
\text { About Serious IIIness } \\
\text { Instrument (PASI) } \\
\text { (USA) } \\
\text { Guide available fromauthor }{ }^{44}\end{array}$ & $\begin{array}{l}\text { Single or } \\
\text { multiple session } \\
\text { face-to-face } \\
\text { conversation in } \\
\text { hospital, } \\
\text { outpatient } \\
\text { or acute care } \\
\text { setting }\end{array}$ & $\begin{array}{l}\text { Seriously ill } \\
\text { patients }\end{array}$ & $\begin{array}{l}\text { Health care } \\
\text { practitioners }\end{array}$ & $\begin{array}{l}\text { Exact scripted } \\
\text { conversation } \\
\text { guide }\end{array}$ & $\begin{array}{l}\text { The interview } \\
\text { instrument } \\
\text { should be used } \\
\text { in conjunction } \\
\text { with an AD }\end{array}$ & & $\begin{array}{l}\text { Whitehead } \\
2016^{44}\end{array}$ & \\
\hline $\begin{array}{l}\text { I22. Patient Navigator } \\
\text { Intervention to improve } \\
\text { palliative care } \\
\text { (USA) } \\
\text { Guide available fromauthor }{ }^{45}\end{array}$ & $\begin{array}{l}\text { Five or more (if } \\
\text { needed) } \\
\text { session face-to- } \\
\text { face } \\
\text { conversation in } \\
\text { setting as } \\
\text { preferred by } \\
\text { patient (home, } \\
\text { outpatient clinic } \\
\text { or during } \\
\text { hospitalization) }\end{array}$ & $\begin{array}{l}\text { Latino adults with } \\
\text { life-limiting illness }\end{array}$ & $\begin{array}{l}\text { Patient } \\
\text { Navigator } \\
\text { (one month long } \\
\text { intensively } \\
\text { training) }\end{array}$ & $\begin{array}{l}\text { - Exact } \\
\text { scripted } \\
\text { conversation } \\
\text { guide } \\
\text { - Packet of } \\
\text { linguistically } \\
\text { matched } \\
\text { materials on } \\
\text { palliative care } \\
\text { - AD form }\end{array}$ & $\begin{array}{l}\text { - Completion of } \\
\text { AD - } \\
\text { Documentation } \\
\text { of pain } \\
\text { management }\end{array}$ & & $\begin{array}{l}\text { Fischer } \\
2015^{45}\end{array}$ & $\begin{array}{l}\text { Fischer } \\
2015^{45}\end{array}$ \\
\hline $\begin{array}{l}\text { I23. Physician's Guide to } \\
\text { Talking About } \\
\text { End-of-Life Care } \\
\text { (USA) } \\
\text { Guide included in article }^{95}\end{array}$ & $\begin{array}{l}\text { Face-to-face } \\
\text { conversation, } \\
\text { preferable in } \\
\text { more than one } \\
\text { session }\end{array}$ & Serious ill patients & Physician & $\begin{array}{l}\text { - Conversation } \\
\text { guide with } \\
\text { question } \\
\text { examples }\end{array}$ & & $\begin{array}{l}\text { Balaban } \\
2000^{96}\end{array}$ & & \\
\hline $\begin{array}{l}\text { I24. Preserving Identity } \\
\text { and Planning for Advance } \\
\text { Care (PIPAC) } \\
\text { (USA) } \\
\text { Guide available fromauthor }{ }^{46}\end{array}$ & $\begin{array}{l}\text { Four session, } \\
\text { one week apart, } \\
\text { face-to-face } \\
\text { conversation } \\
\text { at home } \\
\text { (including } \\
\text { assisted living } \\
\text { facilities and } \\
\text { nursing homes) }\end{array}$ & $\begin{array}{l}\text { Individuals with } \\
\text { early or } \\
\text { mild stage } \\
\text { dementia }\end{array}$ & $\begin{array}{l}\text { Trained } \\
\text { assessors with } \\
\text { social worker or } \\
\text { psychology } \\
\text { background }\end{array}$ & $\begin{array}{l}\text { - Exact } \\
\text { scripted } \\
\text { conversation } \\
\text { guide } \\
\text { - Participant } \\
\text { notebook } \\
\text { - Checklist } \\
\text { - Document } \\
\text { contributions } \\
\text { participants } \\
\text { - Materials for } \\
\text { a reminiscence } \\
\text { product }\end{array}$ & $\begin{array}{l}\text { - A tangible } \\
\text { reminiscence } \\
\text { product } \\
\text { - Consideration } \\
\text { of completing a } \\
\text { legal document }\end{array}$ & & $\begin{array}{l}\text { Hilgeman } \\
2014^{46}\end{array}$ & $\begin{array}{l}\text { Hilgeman } \\
2014^{46}\end{array}$ \\
\hline
\end{tabular}




\begin{tabular}{|c|c|c|c|c|c|c|c|c|}
\hline $\begin{array}{l}\text { I25. Respecting } \text { Choices }^{\text {a }} \\
\text { (USA) } \\
\text { Copyrighted: guide partial } \\
\text { available in article } \\
\text { Guide available fromauthor }^{89}\end{array}$ & $\begin{array}{l}\text { Single session } \\
\text { face-to-face } \\
\text { conversation } \\
\text { at diverse } \\
\text { settings, mostly } \\
\text { outpatient } \\
\text { facilities }\end{array}$ & 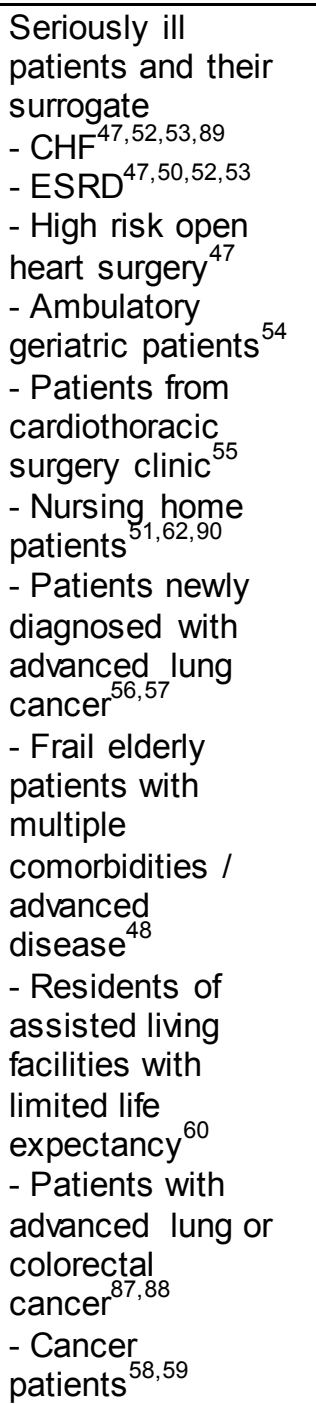 & $\begin{array}{l}\text { Trained } \\
\text { facilitator } \\
\text { (Respecting } \\
\text { Choices } \\
\text { training) }\end{array}$ & $\begin{array}{l}\text { - Exact } \\
\text { scripted } \\
\text { conversation } \\
\text { guide } \\
\text { - Training } \\
\text { program for } \\
\text { facilitators } \\
\text { - Information } \\
\text { for patients } \\
\text { - Checklist for } \\
\text { interview }\end{array}$ & $\begin{array}{l}\text { Completion of } \\
A D\end{array}$ & $\begin{array}{l}\text { Briggs } \\
2004^{86} \\
\text { Korfhage } \\
2015^{87, b} \\
\text { Rietjens } \\
2016^{87, b} \\
\text { Malhotra } \\
2016^{89, b} \\
\text { In der } \\
\text { Schmitten } \\
2011^{90, b}\end{array}$ & $\begin{array}{l}\text { Briggs } \\
2004^{47} \\
\text { Boettcher } \\
2014^{48} \\
\text { Hall }_{2014^{49}} \\
\text { Song }^{50} \\
2010^{50} \\
\text { In der } \\
\text { Schmitten } \\
2014^{51} \\
\text { Kirchhoff } \\
2010^{52} \\
\text { Schwartz } \\
2002^{54} \\
\text { Song } \\
2005^{55} \\
\text { Robinson } \\
2011^{56} \\
\text { Robinson } \\
2012^{57} \\
\text { Niranjan } \\
2018^{58} \\
\text { Rocque } \\
2017^{59}\end{array}$ & $\begin{array}{l}\text { Boettcher } \\
2014^{48} \\
\text { Hall } \\
2014^{49} \\
\text { Hammes } \\
2010^{60} \\
\text { Pecanac } \\
2016^{61} \\
\text { Song } \\
2010^{50} \\
\text { In der } \\
\text { Schmitten } \\
2014^{51} \\
\text { Kirchhoff } \\
2010^{52} \\
\text { Kirchhoff } \\
2012^{53} \\
\text { Schwartz } \\
2002^{54} \\
\text { Song } \\
2005^{55} \\
\text { Briggs } \\
2004^{47} \\
\text { Robinson } \\
2011^{56} \\
\text { Rocque } \\
2017^{59} \\
\text { Hickman } \\
2016^{62}\end{array}$ \\
\hline $\begin{array}{l}\text { I26. Scripted Nurse pre- } \\
\text { VAD Visits } \\
\text { (USA) } \\
\text { Guide included in article }^{63}\end{array}$ & $\begin{array}{l}\text { Face-to-face } \\
\text { conversation } \\
\text { in outpatient or } \\
\text { inpatient setting }\end{array}$ & $\begin{array}{l}\text { Patients at } \\
\text { evaluation for VAD } \\
\text { placement }\end{array}$ & $\begin{array}{l}\text { Palliative Care } \\
\text { nurse }\end{array}$ & $\begin{array}{l}\text { Exact scripted } \\
\text { conversation } \\
\text { guide }\end{array}$ & $\begin{array}{l}\text { - Document in } \\
\text { EHR } \\
\text { - Full palliative } \\
\text { care consult if } \\
\text { needed }\end{array}$ & & $\begin{array}{l}\text { O'Connor } \\
2016^{63}\end{array}$ & \\
\hline
\end{tabular}




\begin{tabular}{|c|c|c|c|c|c|c|c|c|}
\hline $\begin{array}{l}\text { I27. Serious IIIness } \\
\text { Conversation Guide } \\
\text { (USA) } \\
\text { Guide available from: } \\
\text { https://www.ariadnelabs.org/areas- } \\
\text { of-work/serious-illness-care/ }\end{array}$ & $\begin{array}{l}\text { Single or } \\
\text { multiple session } \\
\text { face-to-face } \\
\text { conversation at } \\
\text { oncology care } \\
\text { clinics }\end{array}$ & $\begin{array}{l}\text { Seriously ill } \\
\text { patients } \\
\text { - patients with } \\
\text { advanced } \\
\text { incurable cancer } \\
\text { and surrogates }\end{array}$ & $\begin{array}{l}\text { Clinicians } \\
(2,5 \text { hour } \\
\text { training } \\
\text { program })\end{array}$ & $\begin{array}{l}\text { - Exact } \\
\text { scripted } \\
\text { conversation } \\
\text { guide } \\
\text { - Patient pre- } \\
\text { visit-letter and } \\
\text { guide } \\
\text { - Clinician } \\
\text { reference } \\
\text { guide }\end{array}$ & $\begin{array}{l}\text { Structured } \\
\text { documentation } \\
\text { in } \\
\text { Electronic } \\
\text { Health Record }\end{array}$ & $\begin{array}{l}\text { Bernacki } \\
2015^{91, b}\end{array}$ & $\begin{array}{l}\text { Lakin } \\
2017^{64}\end{array}$ & $\begin{array}{l}\text { Lakin } \\
2017^{64}\end{array}$ \\
\hline $\begin{array}{l}\text { I28. Sharing Patient's } \\
\text { IIIness } \\
\text { Representations to } \\
\text { Increase Trust (SPIRIT) } \\
\text { (USA) } \\
\text { Guide included in article }\end{array}$ & $\begin{array}{l}\text { Single or double } \\
\text { session face-to- } \\
\text { face } \\
\text { conversation at } \\
\text { outpatient clinic } \\
\text { or home }\end{array}$ & $\begin{array}{l}\text { Seriously ill } \\
\text { patients } \\
\text { Adapted for: } \\
\text {-ESRD } \\
\text {-Heart failure with } \\
\text {-HVAD } \\
\text { LVA,66 }^{67,68}\end{array}$ & $\begin{array}{l}\text { Trained nurse } \\
\text { facilitator } \\
\text { ( } 3.5 \text { days of } \\
\text { training) }\end{array}$ & $\begin{array}{l}\text { - Exact } \\
\text { scripted } \\
\text { conversation } \\
\text { guide } \\
\text { - Goals of } \\
\text { Care } \\
\text { document } \\
\text { - Information } \\
\text { about AD }\end{array}$ & $\begin{array}{l}\text { Placement of } \\
\text { Goals of Care } \\
\text { document in } \\
\text { medical record }\end{array}$ & $\begin{array}{l}\text { Song } 2015^{y z} \\
\text { Song } \\
2018^{93, b}\end{array}$ & $\begin{array}{l}\text { Metzger } \\
2016^{65} \\
\text { Metzger } \\
2016^{66} \\
\text { Song } \\
2009^{67} \\
\text { Song } \\
2015^{68} \\
\text { Song }_{26} \\
2016^{76}\end{array}$ & $\begin{array}{l}\text { Metzger } \\
2016^{65} \\
\text { Metzger } \\
2016^{66} \\
\text { Song } \\
2009^{67} \\
\text { Song } \\
2015^{68} \\
\text { Song } \\
2016^{76} \\
\text { Song }_{2017^{69}}\end{array}$ \\
\hline $\begin{array}{l}\text { I29. Structured } \\
\text { intervention to facilitate } \\
\text { EOL DM } \\
\text { (Australia) } \\
\text { Guide available fromauthor }{ }^{70}\end{array}$ & $\begin{array}{l}\text { Face-to-face } \\
\text { conversation }\end{array}$ & $\begin{array}{l}\text { Patients with } \\
\text { metastatic } \\
\text { cancer and their } \\
\text { caregivers }\end{array}$ & Psychologist & $\begin{array}{l}\text { Exact scripted } \\
\text { conversation } \\
\text { guide }\end{array}$ & $\begin{array}{l}\text { DNR order as } \\
\text { preferable } \\
\text { documentation }\end{array}$ & & $\begin{array}{l}\text { Stein } \\
2013^{70}\end{array}$ & $\begin{array}{l}\text { Stein } \\
2013^{70}\end{array}$ \\
\hline 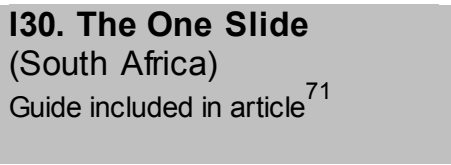 & $\begin{array}{l}\text { Face-to-face } \\
\text { conversation }\end{array}$ & NS & $\begin{array}{l}\text { Health care } \\
\text { professionals, } \\
\text { pastors, } \\
\text { teachers }\end{array}$ & $\begin{array}{l}\text { - Exact } \\
\text { scripted } \\
\text { conversation } \\
\text { guide }\end{array}$ & NS & & $\begin{array}{l}\text { Stanford } \\
2013^{71}\end{array}$ & \\
\hline
\end{tabular}




\begin{tabular}{|c|c|c|c|c|c|c|c|c|}
\hline $\begin{array}{l}\text { I31. Thinking Ahead } \\
\text { Project (TAP) } \\
\text { (USA) } \\
\text { Copyrighted: guide based on } 125 \text {, } \\
\text { partial available fromauthor }\end{array}$ & $\begin{array}{l}\text { Single session } \\
\text { face-to-face } \\
\text { conversation } \\
\text { combining MI } \\
\text { with an adapted } \\
\text { ACP-interview } \\
\text { at university } \\
\text { medical } \\
\text { Center }\end{array}$ & $\begin{array}{l}\text { Community- } \\
\text { dwelling African } \\
\text { Americans }\end{array}$ & $\begin{array}{l}\text { A certified } \\
\text { Respecting } \\
\text { Choices } \\
\text { Facilitator } \\
\text { (additional } 4 \\
\text { hour Ml- } \\
\text { training) }\end{array}$ & $\begin{array}{l}\text { - Exact } \\
\text { scripted } \\
\text { conversation } \\
\text { guide } \\
\text { - Package of } \\
\text { ACP } \\
\text { educational } \\
\text { material with } \\
\text { both the } \\
\text { standard and } \\
\text { health literacy } \\
\text { adapted AD }\end{array}$ & $\begin{array}{l}\text { - Completion of } \\
\text { AD }\end{array}$ & & $\begin{array}{l}\text { Huang } \\
2016^{72}\end{array}$ & $\begin{array}{l}\text { Huang } \\
2016^{72}\end{array}$ \\
\hline $\begin{array}{l}\text { I32. Values-Based History } \\
\text { (USA) } \\
\text { Guide included in article }\end{array}$ & $\begin{array}{l}\text { Face-to-face } \\
\text { conversation } \\
\text { with follow-up } \\
\text { sessions }\end{array}$ & $\begin{array}{l}\text { Patients with } \\
\text { serious illness }\end{array}$ & $\begin{array}{l}\text { Health care } \\
\text { providers }\end{array}$ & $\begin{array}{l}\text { Conversation } \\
\text { guide with } \\
\text { question } \\
\text { examples }\end{array}$ & $\begin{array}{l}\text { Author states } \\
\text { goal is to } \\
\text { establish a } \\
\text { concrete plan }\end{array}$ & $\begin{array}{l}\text { Prommer } \\
2010^{94}\end{array}$ & & \\
\hline $\begin{array}{l}\text { I33. Value Discussion } \\
\text { Guide } \\
\text { (USA) } \\
\text { Guide as appendix }^{73}\end{array}$ & $\begin{array}{l}\text { Facilitated face- } \\
\text { to-face } \\
\text { conversation } \\
\text { after self-guided } \\
\text { discussion at } \\
\text { medical center } \\
\text { or at home }\end{array}$ & $\begin{array}{l}\text { Male veterans with } \\
\text { AD } \\
\text { and their surrogate }\end{array}$ & Psychologist & $\begin{array}{l}\text { Exact scripted } \\
\text { conversation } \\
\text { guide }\end{array}$ & NS & & $\begin{array}{l}\text { Karel } \\
2004^{73}\end{array}$ & $\begin{array}{l}\text { Karel } \\
2004^{73}\end{array}$ \\
\hline $\begin{array}{l}\text { I34. Voicing My Choices } \\
\text { (USA) } \\
\text { Guide included in article } \\
\text { https://fivewishes.org/docs/default- } \\
\text { source/Samples/vmc- } \\
\text { sample.pdf?sfvrsn=4 }\end{array}$ & $\begin{array}{l}\text { Face-to-face } \\
\text { conversation }\end{array}$ & $\begin{array}{l}\text { Adolescents and } \\
\text { young } \\
\text { adults with life- } \\
\text { threatening } \\
\text { conditions }\end{array}$ & $\begin{array}{l}\text { Health care } \\
\text { professionals }\end{array}$ & $\begin{array}{l}\text { - Conversation } \\
\text { guide with } \\
\text { question } \\
\text { examples } \\
\text { - Guide } \\
\text { functions as } \\
\text { planning guide } \\
\text { to document } \\
\text { wishes }\end{array}$ & $\begin{array}{l}\text { - Guide can be } \\
\text { used } \\
\text { as a patient- } \\
\text { held document } \\
\text { to record the } \\
\text { conversation }\end{array}$ & $\begin{array}{l}\text { Zadeh } \\
2015^{95}\end{array}$ & $\begin{array}{l}\text { Smith } \\
2017^{74} \\
\text { Kazmerski } \\
2016^{75}\end{array}$ & \\
\hline \multicolumn{9}{|c|}{ 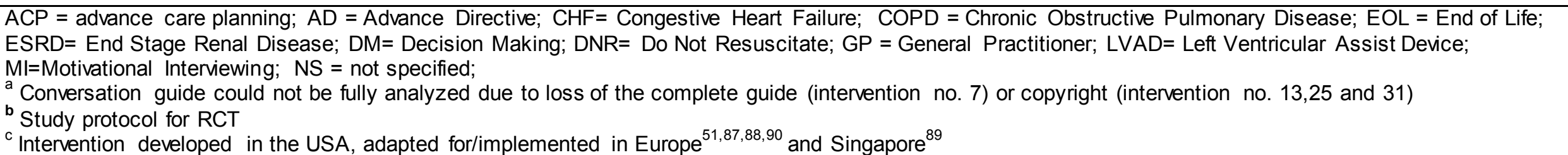 } \\
\hline
\end{tabular}




\section{Content of the conversation guides}

We synthesized a summarizing framework of the structure and content of ACP conversation guides. (Table 3) The main structural elements of the conversations guides consisted of four phases: preparation, initiation, exploration and action. Sample statements, extracted from the conversation guides, are given in Table 3 to illustrate the content. The exploration phase contained the most elaborate statement samples.

\section{Preparation and initiation}

The preparation phase consists of pre-conversational steps, including the identification of eligible patients and practical arrangements. The initiation phase is the start of the actual conversation in most interventions, containing different strategies to introduce $A C P$, to clarify the goal of the conversation and to establish a trustful relationship between patient and interventionist.

\section{Exploration}

In most conversation guides, the exploration of patient's views on multiple themes is the core part of the conversation. Illness understanding and views on living with illness are explored (Intervention:2,3,6,7,11,13-17,20-29,32) as well as views on living well. (Intervention:3,4,7,11,13,16,17,21,22,24-26,29,32) Another key theme in the exploration phase is death and dying, covering both conceptual discussions about death and discussions about practical issues regarding the end of life. (Intervention:3,6,8,12,13,16,17,19,20,22,23,24,25,28,29,34) Themes related to the psychosocial wellbeing of the patient are addressed as well. Fears and worries are discussed (Intervention:2,3,6,7,8,11,12,14,16-18,20,22,24-28,32) and hopes are explored (Intervention:2,3,6,17,24,25,32) as well as sources of strength. (Intervention:12,13,17,18,24,25,29,33,34)

Planning and goal setting form a bridge between the exploration of personal values and the determination of preferences for future medical care. Personal views on planning and decisionmaking are explored. (Intervention:2,3,4,6,8,10,11,19,22,28,33,34) Patients' locus of control 
(Intervention:1-6,11,12,26,27,29,34) and the desired involvement of family and professionals in care and decision-making are discussed. (Intervention:1,4-8,11-13,17,19,21,22,24-27,29,30,32-34)

Goals of care (Intervention:2,6,7,11,14,16,23,25,26,27,28,32) and trade-offs are defined to identify what the participant perceives as tolerable to achieve certain goals (Intervention:3,6,8,11,12,20,23,27-28,32,33) Most interventions address treatment preferences. (Intervention:1,2,5,6,8-17,19,20,21,23-26,29,30,32,34) Some interventions use scenarios or mentioned specific therapies; others evaluate treatment preferences more in general. Some interventions evaluate whether the patient has or would like to have preferences documented in a (legal) document. (Interventions:3,5,11,19,20,25,29,30)

\section{Action}

The last phase of the conversation guide could include a summary. (Intervention:2,3,4,10,11,14,19,22,23,25,27,28,32) Only few interventions make patient-specific recommendations based on the prior explorative phase. (Intervention:10,11,23,25,27,32) Most interventions propose designation of a surrogate decision maker as a concrete action at the end of the conversation. (Intervention:1-4,6,8,9,11,13,17,20,22-26,28-30,32-34) Documentation forms range from notes in the patients' medical record to written documents like Advance Directives, Do-Not-Resuscitate-orders or living wills. (Intervention:1,2,8,14-16,19,20,22,23,24,25,32) One intervention is based on a patient-held document and left the dissemination to the patient. (Intervention: 34) Additional steps could consist of planning follow-up conversations to discuss strategies to share the content of the conversation with family and other health care providers.

Other content of the conversation guide

Some guides provide examples of 'guidance-on-the-job' by the professional as a longitudinal element throughout the conversations. (Intervention:2,10,16,19,22,23,24,25,27,28,34) These are parts of the conversation in which the professional gives information to clarify certain topics or procedures. This includes information about the illness (current state and prognosis), the concept of ACP and surrogate decision makers, specific treatment options, expected patientspecific outcomes, options for documentation and legal issues. 
Table 3. Synthesis of framework for structure and content of conversation guides

\section{GENERAL STRUCTURE OF THE CONVERSATION GUIDES}

\begin{tabular}{|c|c|c|c|}
\hline $\begin{array}{l}\text { Preparation } \\
\text { Initiation } \\
\text { Exploration } \\
\text { Action } \\
\end{array}$ & & & $\begin{array}{l}\text { Identification of eligible patients and creation of appropriate circumstances } \\
\text { Setting up the conversation } \\
\text { Eliciting patient's perspectives on relevant topics } \\
\text { Translate content conversation into concrete steps }\end{array}$ \\
\hline \multicolumn{4}{|l|}{ INITIATION } \\
\hline $\begin{array}{l}\text { Content of } \\
\text { element }\end{array}$ & $\begin{array}{l}\text { Themes in } \\
\text { conversation guides }\end{array}$ & $\begin{array}{l}\text { Covered } \\
\text { in guides } \\
\mathrm{n}(\%)\end{array}$ & Sample statements (Intervention no.) \\
\hline \multirow[t]{3}{*}{$\begin{array}{l}\text { Readiness } \\
\text { patient }\end{array}$} & $\begin{array}{l}\text { Address current } \\
\text { health state }\end{array}$ & $4(12 \%)$ & $\begin{array}{l}\text { 'A few months ago we spoke about what kind of care you would want if you were to become very } \\
\text { ill. We're now facing that situation.' }(23) \\
\text { 'I brought up these issues early so that you would have time to think about what's important to } \\
\text { you. I'm not worried that anything will happen in the next weeks.' (27) }\end{array}$ \\
\hline & $\begin{array}{l}\text { Attitudes to thinking } \\
\text { about the future }\end{array}$ & $\begin{array}{c}11 \\
(32 \%)\end{array}$ & $\begin{array}{l}\text { 'Do you spend time thinking about your health and your future?' (6) } \\
\text { 'Do you think much about the future? What worries you when you think about the future? What } \\
\text { are your hopes for the future?' (3) }\end{array}$ \\
\hline & $\begin{array}{l}\text { Ask permission for } \\
\text { having the } \\
\text { conversation }\end{array}$ & $6(18 \%)$ & $\begin{array}{l}\text { 'To adapt our therapy model to your personal needs, we need to know your preferences } \\
\text { concerning some aspects that characterize our assistance. Do you wish to talk about them at this } \\
\text { time?'(12) } \\
\text { 'Would you like to talk more about the kind of care you would want to have if you were no longer } \\
\text { able to express your own wishes?' (22) }\end{array}$ \\
\hline $\begin{array}{l}\text { Rapport } \\
\text { building }\end{array}$ & $\begin{array}{c}\text { Establish relationship } \\
\text { and trust }\end{array}$ & $5(15 \%)$ & $\begin{array}{l}\text { 'While I can't cure you, there are still many things I can do for you. I want you to be able to speak } \\
\text { openly with me, so I can best help you. No matter what happens, I can be here for you-you are } \\
\text { not alone.' ( } 23 \text { ) } \\
\text { 'As your doctor, I want to make sure we are always doing the things that might help you, and that } \\
\text { we never do anything that either can't help you, or you wouldn't want.' (23) }\end{array}$ \\
\hline \multirow[t]{2}{*}{ Introduction } & $\begin{array}{l}\text { Concept of ACP and } \\
\text { potential benefits }\end{array}$ & $\begin{array}{c}16 \\
(47 \%)\end{array}$ & $\begin{array}{l}\text { 'One thing I like to do with all my patients is to discuss advance care planning. Do you know what } \\
\text { this means?' (10) } \\
\text { 'We want to help you stay in control of decisions about your care, and to ease things in case your } \\
\text { family has to make difficult decisions on your behalf.' (27) }\end{array}$ \\
\hline & $\begin{array}{l}\text { Framing future } \\
\text { situation }\end{array}$ & $5(15 \%)$ & $\begin{array}{l}\text { 'These questions are pertaining to a situation in which you are either no longer able to express } \\
\text { your wishes, or are in an unsound mental state for making rational decisions-that is, a situation } \\
\text { when someone else will have to make medical decisions for you.' (30) }\end{array}$ \\
\hline
\end{tabular}




\begin{tabular}{|c|c|c|c|}
\hline $\begin{array}{l}\text { Content of } \\
\text { element }\end{array}$ & $\begin{array}{l}\text { Themes in } \\
\text { conversation guides }\end{array}$ & $\begin{array}{l}\text { Covered } \\
\text { in guides } \\
\mathrm{n}(\%)\end{array}$ & Sample statements (Intervention no.) \\
\hline & $\begin{array}{c}\text { Clarifying } \\
\text { conversation goals }\end{array}$ & $\begin{array}{c}11 \\
(32 \%)\end{array}$ & $\begin{array}{l}\text { 'I know this is hard to talk about, but l'd like to see if we can clarify a couple things about what } \\
\text { your worries are about the future.' ( } 27 \text { ) } \\
\text { 'We've talked about some of the key issues that are important as you get sicker, and I think it } \\
\text { would be helpful to get a bit more specific about the types of treatments that do and don't make } \\
\text { sense in your situation.' (27) }\end{array}$ \\
\hline & $\begin{array}{l}\text { Consider invitation } \\
\text { others }\end{array}$ & $2(6 \%)$ & 'Is there someone you would like to be present with you for these conversations?' (11) \\
\hline \multicolumn{4}{|c|}{ EXPLORATION } \\
\hline \multirow[t]{2}{*}{ Illness views } & $\begin{array}{c}\text { Illness } \\
\text { understanding }\end{array}$ & $17(50 \%)$ & $\begin{array}{l}\text { 'What do you understand about your illness or what's happening to you?' (11) } \\
\text { 'What is your understanding of your treatment options; your prognosis?' (16) }\end{array}$ \\
\hline & Living with illness & $13(38 \%)$ & $\begin{array}{l}\text { 'How have you been feeling since you were given your diagnosis?' (4) } \\
\text { 'Tell me about living with COPD day-to-day?' (3) }\end{array}$ \\
\hline Live views & Living well & $19(56 \%)$ & $\begin{array}{l}\text { 'What makes life worth living?' (3) } \\
\text { 'What activities or experiences are most important for you to live well?' (25) }\end{array}$ \\
\hline \multirow[t]{2}{*}{$\begin{array}{l}\text { Views on } \\
\text { death and } \\
\text { dying }\end{array}$} & Prior experiences & $7(20 \%)$ & $\begin{array}{l}\text { 'How have you dealt with loss/death in the past? What do you wish had been different? What } \\
\text { was OK for them, but would not be OK for you?' (6) } \\
\text { 'Have you or someone close to you had experiences with serious illness or death?' (8) }\end{array}$ \\
\hline & $\begin{array}{l}\text { Vision on end-of- } \\
\quad \text { life }\end{array}$ & $13(38 \%)$ & $\begin{array}{l}\text { 'We cannot predict exactly what medical treatment you might need at the end of your life. But it's } \\
\text { important for me to know your thoughts about what type of medical care you would like to } \\
\text { receive. How do you imagine spending your last days, weeks, and months?' (23) } \\
\text { 'Have you thought about dying (if they have not named this specifically)? Can you tell me more } \\
\text { about these things?' (16) }\end{array}$ \\
\hline \multirow[t]{3}{*}{$\begin{array}{l}\text { Psycho- } \\
\text { social } \\
\text { wellbeing }\end{array}$} & Coping & $8(24 \%)$ & $\begin{array}{l}\text { 'When people get to this stage, some people feel like they want to keep fighting, and other } \\
\text { people feel like they just want to be comfortable and let things happen as they may. How are you } \\
\text { feeling now?' (23) } \\
\text { 'How are you coping with all of this?' (16) }\end{array}$ \\
\hline & Fears and worries & $19(56 \%)$ & 'What worries you most? What is your greatest fear? What helps with this worry and fear?' (3) \\
\hline & Hope & $7(20 \%)$ & 'As you think about how things are going with the illness, what are you hoping for?' (3) \\
\hline
\end{tabular}




\begin{tabular}{|c|c|c|c|}
\hline $\begin{array}{l}\text { Content of } \\
\text { element }\end{array}$ & $\begin{array}{l}\text { Themes in } \\
\text { conversation guides }\end{array}$ & $\begin{array}{l}\text { Covered } \\
\text { in guides } \\
\mathrm{n}(\%)\end{array}$ & Sample statements (Intervention no.) \\
\hline & $\begin{array}{l}\text { Religion and } \\
\text { spirituality }\end{array}$ & $10(29 \%)$ & $\begin{array}{l}\text { 'Do you have any religious or spiritual beliefs that help you deal with difficult times? If so, tell } \\
\text { about them. '(24) }\end{array}$ \\
\hline \multirow[t]{8}{*}{$\begin{array}{l}\text { Planning and } \\
\text { decision } \\
\text { making }\end{array}$} & Prior experiences & $12(35 \%)$ & $\begin{array}{l}\text { 'Have you had any thoughts, discussions with your family or friends about what you would like to } \\
\text { happen, if you become very ill and needed more support and care?' (4) } \\
\text { 'What experience do you have in making health-related choices (for self or others)?' }\end{array}$ \\
\hline & Locus of control & $11(32 \%)$ & $\begin{array}{l}\text { 'If there are any major decisions, do you prefer: for the doctors to make the decisions / for the } \\
\text { doctors to give you all the information and help you make the decision / for you and your family } \\
\text { to discuss and decide together / for you alone to make the decision / other?' (5) } \\
\text { 'What would you like to know about your care and treatment, how much information do you } \\
\text { normally like to have? Are you the sort of person that likes to have all of the information, or would } \\
\text { you prefer not to know too much?' (4) }\end{array}$ \\
\hline & Goal setting & $12(35 \%)$ & 'If your health situation worsens, what are your most important goals?' (27) \\
\hline & Trade offs & $12(35 \%)$ & 'How much are you willing to go through for the possibility of gaining more time?' (27) \\
\hline & $\begin{array}{l}\text { Treatment } \\
\text { preferences }\end{array}$ & $32(94 \%)$ & $\begin{array}{l}\text { 'The staff here will always try and advise what is in your best interests, and will discuss this with } \\
\text { you whenever possible. It is helpful, however, to know if you have any particular preferences for } \\
\text { or against specific treatments?' (6) } \\
\text { 'Are there certain treatments that you think you would never want? Why?' (5) }\end{array}$ \\
\hline & Other preferences & $11(32 \%)$ & $\begin{array}{l}\text { 'If you could choose, would you prefer to die at home, in hospice, in residential care, or in } \\
\text { hospital?' (11) }\end{array}$ \\
\hline & & & $\begin{array}{l}\text { 'Do you have any specific religious or spiritual needs which you would like to be adhered to } \\
\text { wherever you are cared for, such as attending a local church, or meeting place?' (12) } \\
\text { 'Do you have other preferences that we did not address?' (21) }\end{array}$ \\
\hline & Documentation & $7(21 \%)$ & 'Have you ever written down your wishes about future care or treatment?' (5) \\
\hline $\begin{array}{l}\text { Involvement } \\
\text { of others }\end{array}$ & Family & $21(62 \%)$ & $\begin{array}{l}\text { 'Have you talked with your family about your health?' (16) } \\
\text { 'If they ask us, may we talk to your family about your illness? Is there anyone in your family } \\
\text { whom you would prefer us not to give information to? Do you prefer anyone particular to be with } \\
\text { you to hear results or to discuss and make important decisions about your care and treatments?' } \\
\text { (5) }\end{array}$ \\
\hline
\end{tabular}




\begin{tabular}{|c|c|c|c|}
\hline $\begin{array}{l}\text { Content of } \\
\text { element }\end{array}$ & $\begin{array}{l}\text { Themes in } \\
\text { conversation guides }\end{array}$ & $\begin{array}{c}\text { Covered } \\
\text { in guides } \\
\mathrm{n}(\%)\end{array}$ & Sample statements (Intervention no.) \\
\hline & Professionals & $8(24 \%)$ & $\begin{array}{l}\text { 'How much does your primary care provider know about what's important to you? What } \\
\text { questions do you need to ask him or her?' (8) } \\
\text { 'What do you expect of your health care providers: availability? Information? Participation in } \\
\text { decision making?' (6) }\end{array}$ \\
\hline
\end{tabular}

\begin{tabular}{|c|c|c|c|}
\hline \multicolumn{4}{|r|}{ ( } \\
\hline \multirow[t]{3}{*}{ Summarize } & $\begin{array}{c}\text { Check } \\
\text { understanding }\end{array}$ & $8(24 \%)$ & $\begin{array}{l}\text { 'You have previously said to me that when your time comes, we will let nature take its course. I } \\
\text { will make sure that you are comfortable at all times, and that ultimately, you are able to die } \\
\text { comfortably. We will not plan to use cardiopulmonary resuscitation or breathing machines or an } \\
\text { intensive care unit. Am I correctly stating your preferences?' (23) }\end{array}$ \\
\hline & $\begin{array}{l}\text { Looking back on } \\
\text { discussion }\end{array}$ & $5(15 \%)$ & $\begin{array}{l}\text { 'What was your goal regarding advance care planning or having a conversation, and how did it } \\
\text { go?' (8) }\end{array}$ \\
\hline & Recommendations & $6(18 \%)$ & $\begin{array}{l}\text { 'It sounds like...... is very important to you. Given your goals and priorities and what we know } \\
\text { about your illness at this stage, I recommend...' (27) } \\
\text { 'Based on the wide spread of your cancer, the fact that we have no more treatments to stop the } \\
\text { growth of the cancer, and the fact that CPR doesn't work for patients with metastatic cancer, I } \\
\text { recommend that we focus intensively on your comfort, on helping you have as much time as } \\
\text { possible with your family, and on getting you home.' (27) }\end{array}$ \\
\hline \multirow[t]{2}{*}{ Agreements } & $\begin{array}{l}\text { Surrogate-decision } \\
\text { maker }\end{array}$ & $\begin{array}{c}22 \\
(65 \%)\end{array}$ & $\begin{array}{l}\text { 'If you cannot, or choose not to participate in health care decisions, with whom should we } \\
\text { speak?' (9) } \\
\text { 'Have you thought about who you might want to make decisions for you? If so, who?' (24) }\end{array}$ \\
\hline & Documentation & $\begin{array}{c}17 \\
(50 \%)\end{array}$ & $\begin{array}{l}\text { 'Would you like any help with writing down your wishes and appointing the right person or people } \\
\text { to act for you?' (30) }\end{array}$ \\
\hline Follow-up & Next steps & $\begin{array}{c}12 \\
(35 \%)\end{array}$ & 'What are your next steps regarding advance care planning?' (8) \\
\hline
\end{tabular}




\section{Feasibility and Effectiveness}

Empirical data on the interventions were very heterogeneous because of varying study designs and outcome measures. Inclusion of patients in the studies seemed to be challenging, as reflected by a wide range of eligibility rates and a participant refusal rate of more than $50 \%$ in multiple studies. ${ }^{22-24,45,48,51,54,55,73}$ Reported reasons for refusal were: already having an AD or being engaged in an ACP-discussion, lack of interest and logistic problems (too busy and traveling issues). ${ }^{22,23,45,55}$ After inclusion, the completion rate of the interventions was $>75 \%$ in most studies. $22-24,29,30,35-37,40,42,43,46,47,49,51,63$ Two studies reported much lower completion rates. In one study, evaluating a two-step interview, only $33 \%$ of the participants completed the full interview, including the second part concerning death and dying. ${ }^{26}$ Another study evaluated a program with five visits from a patient navigator. ${ }^{45}$ Only $31 \%$ of the participants received all visits.

Eleven interventions were evaluated in a randomized ${ }^{24,25,29-35,37,40,45-47,50-55,64,68,70,76}$ or nonrandomized controlled trial $\left.\right|^{40,51,64}$ (Table 4) The main body of evidence concerns three interventions: Respecting Choices ( $n=$ six trials described in seven articles) ${ }^{47,50-55}$, SPIRIT ( $n=$ four trials, described in six articles) ${ }^{65-69,76}$ and FACE $(n=\text { three trials, described in ten articles })^{28-37}$.

Measurements in RCT's focused on process measures such as knowledge about ACP, documentation rates, discussion rates, quality of communication, decisional conflict and dyad congruence on treatment preferences. (Table 4) Dyad congruence and documentation rates improved due to the interventions. ${ }^{29,33-35,45,47,51,52,54,55,64,68,76}$ For the remaining process measures results were mixed. Measurements of quality of life, psychosocial wellbeing, hospice use and concordance of preferences and received care were used less often and the results were mixed as well.

Twelve observational studies and nine mixed-method studies showed similar results, reporting a positive trend towards sharing of information with surrogates 22,23,35,42,65,67 and improved documentation rates. ${ }^{16,23,42,43,48,49,60,61}$ (Table 5 and Table 6) Studies evaluating patient's perspectives on ACP conversations, reported a perceived positive experience. ${ }^{20,22,28,42,67,72,75}$ 
Qualitative data showed that participation in ACP conversations was experienced as positive and beneficial by participants on the one hand.(Appendix Table A7) ${ }^{17-19,21,22,43,56,65-67,69,72}$ On the other hand the conversations were also described as difficult and emotional. ${ }^{17,56,57,66,67,73}$ ACP conversations had a positive influence on relationships with relatives and surrogate decision makers. ${ }^{18,19,56,66,67,69,73}$ 
Table 4. Evidence from trials

\begin{tabular}{|c|c|c|c|c|c|c|}
\hline $\begin{array}{l}\text { Author, year, } \\
\text { country }\end{array}$ & Methods & $\begin{array}{l}\text { Population } \\
\text { no. }\end{array}$ & $\begin{array}{l}\text { Outcomes } \\
\text { Decreased } \\
\text { (use of) }\end{array}$ & $\begin{array}{l}\text { Increased } \\
\text { (use of) }\end{array}$ & $\begin{array}{l}\text { No difference } \\
\text { (in use of) }\end{array}$ & $\begin{array}{l}\text { Risk of } \\
\text { Bias } \\
\text { Total score }\end{array}$ \\
\hline \multicolumn{7}{|c|}{ 110. Communication about EOL care among patients with COPD } \\
\hline $\begin{array}{l}\text { Au } 2012^{24} \\
\text { USA }\end{array}$ & $\begin{array}{l}\text { RCT } \\
\text { Patient-specific } \\
\text { feedback form } \\
\text { vs standard } \\
\text { form }\end{array}$ & $\begin{array}{l}\text { Patients with } \\
\text { COPD } \\
n=376 \text { (I: } 194 \mathrm{C:} \\
182 \text { ) }\end{array}$ & & $\begin{array}{l}\text { Quality of } \\
\text { communication } \\
\text { Discussions with } \\
\text { surrogates } \\
\text { Discussions with } \\
\text { clinicians }\end{array}$ & & 2 of 6 \\
\hline $\begin{array}{l}\text { Reinke } 2017^{25} \\
\text { USA }\end{array}$ & $\begin{array}{l}\text { Subanalysis } \\
\text { RCT } \\
\text { Patient-specific } \\
\text { feedback form } \\
\text { vs standard } \\
\text { form }\end{array}$ & $\begin{array}{l}\text { Patients with } \\
\text { COPD who died } \\
\text { after study } \\
\text { completion } \\
n=157\end{array}$ & & & $\begin{array}{l}\text { Documentation of } \\
\text { EOL care discussions } \\
\text { Completion of AD's } \\
\text { Hospice referrals }\end{array}$ & 2 of 6 \\
\hline $\begin{array}{l}\text { I13. Family/Ac } \\
\text { Lyon } 2009^{2 y} \\
\text { USA }\end{array}$ & $\begin{array}{l}\text { escents - Cente } \\
\text { RCT } \\
\text { FACE vs } \\
\text { Adolescent } \\
\text { Health Control } \\
\text { Condition }\end{array}$ & $\begin{array}{l}\text { d (FACE) ACP inter } \\
\text { Adolescents with } \\
\text { HIV/ AIDS } \\
n=38 \text { dyads (I: } 20 \\
\text { C:18) }\end{array}$ & $\begin{array}{l}\text { ention } \\
\text { Decisional conflict }\end{array}$ & $\begin{array}{l}\text { Quality of } \\
\text { communication } \\
\text { Completion of } A D\end{array}$ & Dyad congruence & 3 of 6 \\
\hline $\begin{array}{l}\text { Lyon } 2009^{30} \\
\text { USA }\end{array}$ & “ & “ & & $\begin{array}{l}\text { Satisfaction with } \\
\text { intervention }\end{array}$ & & 4 of 6 \\
\hline $\begin{array}{l}\text { Lyon } 2010^{31} \\
\text { USA }\end{array}$ & “ & “ & & & $\begin{array}{l}\text { Depression } \\
\text { Anxiety } \\
\text { Quality of life } \\
\text { Likelihood to } \\
\text { discontinue treatment }\end{array}$ & 4 of 6 \\
\hline $\begin{array}{l}\text { Lyon } 2011^{32} \\
\text { USA }\end{array}$ & “ & “ & & & Spirituality & 3 of 6 \\
\hline
\end{tabular}




\begin{tabular}{|c|c|c|c|c|c|c|}
\hline $\begin{array}{l}\text { Author, year, } \\
\text { country }\end{array}$ & Methods & $\begin{array}{l}\text { Population } \\
\text { no. }\end{array}$ & $\begin{array}{l}\text { Outcomes } \\
\text { Decreased } \\
\text { (use of) } \\
\end{array}$ & $\begin{array}{l}\text { Increased } \\
\text { (use of) }\end{array}$ & $\begin{array}{l}\text { No difference } \\
\text { (in use of) }\end{array}$ & $\begin{array}{c}\text { Risk of } \\
\text { Bias } \\
\text { Total score }\end{array}$ \\
\hline $\begin{array}{l}\text { Lyon } 2013^{J 5} \\
\text { USA }\end{array}$ & $\begin{array}{l}\text { RCT } \\
\text { FACE vs usual } \\
\text { care }\end{array}$ & $\begin{array}{l}\text { Adolescents with } \\
\text { cancer } \\
\mathrm{n}=30 \text { dyads } \\
(\mathrm{l}: 17 \mathrm{C}: 13)\end{array}$ & Decisional conflict & $\begin{array}{l}\text { Dyad congruence } \\
\text { Likelihood to } \\
\text { discontinue treatment }\end{array}$ & $\begin{array}{l}\text { Quality of } \\
\text { communication }\end{array}$ & 3 of 6 \\
\hline $\begin{array}{l}\text { Lyon } 2014^{34} \\
\text { USA }\end{array}$ & “ & " & & Completion of AD & $\begin{array}{l}\text { Anxiety } \\
\text { Depression } \\
\text { Quality of life } \\
\text { Spiritual well-being }\end{array}$ & 3 of 6 \\
\hline $\begin{array}{l}\text { Dallas, } 2016^{3 \prime} \\
\text { USA }\end{array}$ & $\begin{array}{l}\text { RCT } \\
\text { FACE vs } \\
\text { Adolescent } \\
\text { Health Control } \\
\text { Condition }\end{array}$ & $\begin{array}{l}\text { Adolescents with } \\
\text { HIV and surrogate } \\
n=97 \text { dyads (l:48 } \\
\text { C:49) }\end{array}$ & & $\begin{array}{l}\text { Self-report of both } \\
\text { positive and negative } \\
\text { emotions based on } \\
\text { Satisfaction } \\
\text { Questionnaire }\end{array}$ & & 4 of 6 \\
\hline $\begin{array}{l}\text { Lyon } 2017^{30} \\
\text { USA }\end{array}$ & “ & “ & & $\begin{array}{l}\text { Dyad congruence } \\
\text { Likelihood of } \\
\text { treatment limitations }\end{array}$ & $\begin{array}{l}\text { Leeway of surrogate } \\
\text { regarding EOL } \\
\text { decisions }\end{array}$ & 4 of 6 \\
\hline $\begin{array}{l}\text { I17. Let me Talk } \\
\text { Chan } 2010^{4 U} \\
\text { China }\end{array}$ & $\begin{array}{l}\text { Pre-post- } \\
\text { controlled trial } \\
\text { Let me Talk vs } \\
\text { usual care }\end{array}$ & $\begin{array}{l}\text { Frail but } \\
\text { competent nursing } \\
\text { home residents } \\
\mathrm{n}=121 \text { (I: } 59 \mathrm{C:} \\
62 \text { ) }\end{array}$ & & $\begin{array}{l}\text { Concordance on LST- } \\
\text { preferences over time } \\
\text { Quality of life } \\
\text { Discussions with } \\
\text { family or HCP }\end{array}$ & & 1 of 6 \\
\hline $\begin{array}{l}\text { I22. Patient Navic } \\
\text { Fischer, } 2015^{45} \\
\text { USA }\end{array}$ & $\begin{array}{l}\text { gator Interventic } \\
\text { RCT } \\
\text { patient } \\
\text { navigator } \\
\text { intervention vs } \\
\text { information } \\
\text { packet }\end{array}$ & $\begin{array}{l}\text { to improve palliati } \\
\text { Latino adults with } \\
\text { life-limiting illness } \\
n=64 \text { (l: } 32 \text { C: } 32 \text { ) } \\
\text { Decedents after } 12 \\
\text { months } \\
n=18 \text { (l: } 10 \text { C: } 8)\end{array}$ & & $\begin{array}{l}\text { Completion AD } \\
\text { Documentation pain } \\
\text { management }\end{array}$ & $\begin{array}{l}\text { Outpatient pain } \\
\text { medication order } \\
\text { Hospice use }\end{array}$ & 3 of 6 \\
\hline
\end{tabular}




\begin{tabular}{|c|c|c|c|c|c|c|}
\hline $\begin{array}{l}\text { Author, year, } \\
\text { country }\end{array}$ & Methods & $\begin{array}{l}\text { Population } \\
\text { no. }\end{array}$ & $\begin{array}{l}\text { Outcomes } \\
\text { Decreased } \\
\text { (use of) }\end{array}$ & $\begin{array}{l}\text { Increased } \\
\text { (use of) }\end{array}$ & $\begin{array}{l}\text { No difference } \\
\text { (in use of) }\end{array}$ & $\begin{array}{c}\text { Risk of } \\
\text { Bias } \\
\text { Total score }\end{array}$ \\
\hline \multicolumn{7}{|c|}{ 124. Preserving Identity and Planning for Advance Care (PIPAC) } \\
\hline $\begin{array}{l}\text { Hilgeman } \\
2014^{46} \\
\text { USA }\end{array}$ & $\begin{array}{l}\text { RCT } \\
\text { PIPAC vs } \\
\text { minimal } \\
\text { support phone } \\
\text { contact }\end{array}$ & $\begin{array}{l}\text { Individuals with } \\
\text { early dementia } \\
\mathrm{n}=18 \text { dyads (I: } 11 \\
\mathrm{C}: 8 \text { ) }\end{array}$ & $\begin{array}{l}\text { Scale for Depression } \\
\text { in Dementia } \\
\text { Self-reported mobility } \\
\text { dependence } \\
\text { Decisional conflict }\end{array}$ & $\begin{array}{l}\text { Subjective quality of } \\
\text { life in Dementia } \\
\text { Coping strategies }\end{array}$ & $\begin{array}{l}\text { Anxiety } \\
\text { Quality of life in } \\
\text { Alzheimer's Disease } \\
\text { Meaning in life Scale } \\
\text { Social Engagement } \\
\text { Emotional and } \\
\text { anticipated support } \\
\text { scale }\end{array}$ & 3 of 6 \\
\hline \multicolumn{7}{|c|}{ 125. Respecting Choices (RC) } \\
\hline $\begin{array}{l}\text { Schwartz } 2002^{54} \\
\text { USA }\end{array}$ & $\begin{array}{l}R C T \\
R C \text { vs local } \\
\text { proxy form }\end{array}$ & $\begin{array}{l}\text { Ambulatory } \\
\text { geriatric } \\
\text { patients } \\
\mathrm{n}=61 \text { (I: } 31 \text { C:30) }\end{array}$ & & $\begin{array}{l}\text { ACP knowledge } \\
\text { Dyad congruence } \\
\text { Comfort proxy as } \\
\text { decision maker }\end{array}$ & $\begin{array}{l}\text { VAS pain, anxiety } \\
\text { alertness }\end{array}$ & 3 of 6 \\
\hline $\begin{array}{l}\text { Briggs, } 2004^{4 \prime} \\
\text { USA }\end{array}$ & $\begin{array}{l}R C T \\
R C \text { vs usual } \\
\text { care }\end{array}$ & $\begin{array}{l}\text { Patients with } \\
\text { ESRD, ESHF, HR- } \\
\text { heart surgery } \\
n=27 \text { dyads (l:13 } \\
\text { C: } 14)\end{array}$ & Decisional conflict & $\begin{array}{l}\text { Quality of } \\
\text { communication } \\
\text { Dyad congruence }\end{array}$ & ACP knowledge & 1 of 6 \\
\hline $\begin{array}{l}\text { Song } 2005^{55} \\
\text { USA }\end{array}$ & $\begin{array}{l}\text { RCT } \\
\text { RC vs usual } \\
\text { care }\end{array}$ & $\begin{array}{l}\text { Patients at } \\
\text { cardiothoracic } \\
\text { surgery clinic } \\
n=32 \text { dyads (I: } \\
16 \text { C:16) }\end{array}$ & Decisional conflict & Dyad congruence & $\begin{array}{l}\text { Anxiety } \\
\text { ACP knowledge }\end{array}$ & 1 of 6 \\
\hline $\begin{array}{l}\text { Song } 2010^{50} \\
\text { USA }\end{array}$ & $\begin{array}{l}\text { RCT } \\
\text { RC vs usual } \\
\text { care }\end{array}$ & $\begin{array}{l}\text { African Americans } \\
\text { with stage } 5 \text { CKD } \\
n=17 \text { dyads (l: } 10 \\
\text { C: } 7 \text { ) }\end{array}$ & & $\begin{array}{l}\text { Quality of } \\
\text { communication } \\
\text { Dyad congruence } \\
\text { Preference for LST }\end{array}$ & $\begin{array}{l}\text { Decisional Conflict } \\
\text { Self-perception and } \\
\text { relationship } \\
\text { Patient clinician } \\
\text { interaction } \\
\text { Cultural sensitivity } \\
\text { clinician }\end{array}$ & 4 of 6 \\
\hline
\end{tabular}




\begin{tabular}{|c|c|c|c|c|c|c|}
\hline $\begin{array}{l}\text { Author, year, } \\
\text { country }\end{array}$ & Methods & $\begin{array}{l}\text { Population } \\
\text { no. }\end{array}$ & $\begin{array}{l}\text { Outcomes } \\
\text { Decreased } \\
\text { (use of) }\end{array}$ & $\begin{array}{l}\text { Increased } \\
\text { (use of) }\end{array}$ & $\begin{array}{l}\text { No difference } \\
\text { (in use of) }\end{array}$ & $\begin{array}{c}\text { Risk of } \\
\text { Bias } \\
\text { Total score }\end{array}$ \\
\hline $\begin{array}{l}\text { Kirchhoff } 2010^{52} \\
\text { USA }\end{array}$ & $\begin{array}{l}\mathrm{RCT} \\
\mathrm{RC} \text { vs usual } \\
\text { care }\end{array}$ & $\begin{array}{l}\text { Patients with CHF } \\
\text { or ESRD } \\
n=313 \text { dyads } \\
\text { (I: } 160 \text { C: } 153)\end{array}$ & & $\begin{array}{l}\text { ACP knowledge } \\
\text { Dyad congruence }\end{array}$ & & 2 of 6 \\
\hline $\begin{array}{l}\text { Kirchhoff } 2012^{53} \\
\text { USA }\end{array}$ & $\begin{array}{l}\text { RCT } \\
\text { RC vs usual } \\
\text { care }\end{array}$ & $\begin{array}{l}\text { Deceased patients } \\
\text { with CHF or ESRD } \\
n=110 \text { deaths } \\
\text { (l: } 62 \text { C: } 48 \text { ) }\end{array}$ & & & $\begin{array}{l}\text { Concordance } \\
\text { preferences/EOL care }\end{array}$ & 3 of 6 \\
\hline $\begin{array}{l}\text { In der Schmitten } \\
2014^{51} \\
\text { Germany }\end{array}$ & $\begin{array}{l}\text { Non- } \\
\text { randomized } \\
\text { controlled trial } \\
\text { Beizeiten } \\
\text { Begleiten vs } \\
\text { usual care }\end{array}$ & $\begin{array}{l}\text { Nursing home } \\
\text { patients } \\
n=575 \text { (l: } 136 \mathrm{C:} \\
439)\end{array}$ & & Completion AD & & 0 of 6 \\
\hline \multicolumn{7}{|c|}{ I27. Serious IIIness Conversation Guide (SICG) } \\
\hline $\begin{array}{l}\text { Lakin } 2017^{64} \\
\text { USA }\end{array}$ & $\begin{array}{l}\text { Prospective } \\
\text { implementation } \\
\text { trial } \\
\text { Clinics with } \\
\text { SICG vs control } \\
\text { clinics }\end{array}$ & $\begin{array}{l}\text { Deceased patients } \\
\text { in primary care } \\
\text { clinic } \\
n=178 \text { (I: } 101 \\
\text { C: } 77)\end{array}$ & & $\begin{array}{l}\text { Documentation of } \\
\text { conversations } \\
\text { Comprehensiveness } \\
\text { conversations }\end{array}$ & $\begin{array}{l}\text { Discussion of } \\
\text { prognosis, code } \\
\text { status/LST or EOL } \\
\text { planning } \\
\text { Hospice use }\end{array}$ & 2 of 6 \\
\hline \multicolumn{7}{|c|}{ I28. Sharing Patient's IIIness Representations to Increase Trust (SPIRIT) } \\
\hline $\begin{array}{l}\text { Song } 2015^{\mathrm{b}} \\
\text { USA }\end{array}$ & $\begin{array}{l}\text { RCT, pre- } \\
\text { posttest, } \\
\text { SPIRIT vs } \\
\text { usual care }\end{array}$ & $\begin{array}{l}\text { Patients on } \\
\text { dialysis therapy } \\
\mathrm{n}=210 \text { dyads } \\
\text { (I: } 109 \text { C: } 101) \\
n=45 \text { bereaved } \\
\text { surrogates } \\
\text { (l: } 28 \text { C: } 17)\end{array}$ & $\begin{array}{l}\text { Anxiety, depression } \\
\text { and PTSS symptoms } \\
\text { in surrogate after } \\
\text { patient's death }\end{array}$ & $\begin{array}{l}\text { Dyad congruence } \\
\text { Decision making } \\
\text { confidence surrogate }\end{array}$ & Decisional conflict & 4 of 6 \\
\hline
\end{tabular}




\begin{tabular}{|c|c|c|c|c|c|c|}
\hline $\begin{array}{l}\text { Author, year, } \\
\text { country }\end{array}$ & Methods & $\begin{array}{l}\text { Population } \\
\text { no. }\end{array}$ & $\begin{array}{l}\text { Outcomes } \\
\text { Decreased } \\
\text { (use of) }\end{array}$ & $\begin{array}{l}\text { Increased } \\
\text { (use of) }\end{array}$ & $\begin{array}{l}\text { No difference } \\
\text { (in use of) }\end{array}$ & $\begin{array}{c}\text { Risk of } \\
\text { Bias } \\
\text { Total score }\end{array}$ \\
\hline $\begin{array}{l}\text { Song, } 2016^{16} \\
\text { USA }\end{array}$ & $\begin{array}{l}\text { RCT, pre- } \\
\text { posttest, } \\
\text { SPIRIT vs } \\
\text { usual care }\end{array}$ & $\begin{array}{l}\text { Patients on } \\
\text { dialysis therapy: } \\
\mathrm{n}=69 \text { whites } \\
\text { (I: } 37 \text { C: } 32 \text { ) } \\
\mathrm{n}=141 \text { African } \\
\text { Americans (I: } 72 \\
\text { C: } 69 \text { ) }\end{array}$ & $\begin{array}{l}\text { Decisional conflict } \\
\text { Bereavement } \\
\text { depressive symptoms } \\
\text { surrogates }\end{array}$ & $\begin{array}{l}\text { Dyad congruence } \\
\text { Decision making } \\
\text { confidence surrogates }\end{array}$ & & 4 of 6 \\
\hline \multicolumn{7}{|c|}{ 129. Structured intervention to facilitate End-of-Life decision making } \\
\hline $\begin{array}{l}\text { Stein } 2013^{\prime U} \\
\text { Australia }\end{array}$ & $\begin{array}{l}\text { RCT, } \\
\text { intervention vs } \\
\text { usual care }\end{array}$ & $\begin{array}{l}\text { Patients with } \\
\text { metastatic cancer } \\
\text { and carers } \\
\mathrm{n}=120 \text { patients (I: } \\
55 \text { (45 carers) C: } \\
65 \text { (52 carers) }\end{array}$ & & Knowledge CPR & $\begin{array}{l}\text { Anxiety } \\
\text { Depression } \\
\text { Caregivers reaction } \\
\text { assessment } \\
\text { DNR } \\
\text { Hospital deaths }\end{array}$ & 3 of 6 \\
\hline \multicolumn{7}{|c|}{$\begin{array}{l}\text { ACP = advance care planning; AD = Advance Directive; AIDS = Acquired Immune Deficiency Syndrome; CHF= Congestive Heart Failure; CKD } \\
\text { = Chronic Kidney Disease; COPD = Chronic Obstructive Pulmonary Disease; EOL = End of Life; ESHF = End Stage Heart Failure; ESRD= End } \\
\text { Stage Renal Disease; HCP = Health Care Practitioner; HIV = Human Immunodeficiency Virus; HR = High Risk; LST = Life Sustaining Treatment; } \\
\text { PTSS = Post Traumatic Stress Syndrome; RCT = Randomized Controlled Trial; VAS = Visual Analog Scale; }\end{array}$} \\
\hline
\end{tabular}


Table 5. Evidence from observational studies

\begin{tabular}{|c|c|c|c|c|}
\hline $\begin{array}{l}\text { Author, year, } \\
\text { country }\end{array}$ & $\begin{array}{l}\text { Aim and } \\
\text { methods }\end{array}$ & $\begin{array}{l}\text { Population } \\
\text { no. }\end{array}$ & Outcomes & $\begin{array}{l}\text { Risk of Bias } \\
\text { Total score }\end{array}$ \\
\hline \multicolumn{5}{|c|}{ 11. ACP for adults with congenital/pediatric heart disease } \\
\hline $\begin{array}{l}\text { Edwards } 2017^{16} \\
\text { USA }\end{array}$ & $\begin{array}{l}\text { * To report } \\
\text { results of } \\
\text { quality } \\
\text { improvement } \\
\text { project for } A C P \\
{ }^{*} \text { Chart review }\end{array}$ & $\begin{array}{l}\text { Patients } \geq 18 \text { years } \\
\text { at Heart Failure } \\
\text { and Transplant } \\
\text { Clinic } \\
\mathrm{n}=58\end{array}$ & $\begin{array}{l}\text { * At baseline no documented ACP discussions or AD, after one year } \\
75 \% \text { of adult encounters had a documented ACP discussion and } 42 \% \\
\text { had a documented } A D\end{array}$ & 2 of 7 \\
\hline \multicolumn{5}{|c|}{ 15. ACP in geriatric patients } \\
\hline $\begin{array}{l}\text { Friis } 2015^{20} \\
\text { USA }\end{array}$ & $\begin{array}{l}\text { * To test } \\
\text { feasibility of } \\
\text { systematic } \\
\text { ACP } \\
\text { discussions } \\
{ }^{*} \text { Categorized } \\
\text { patient reports }\end{array}$ & $\begin{array}{l}\text { Patients admitted } \\
\text { to Geriatric ward of } \\
\text { hospital } \\
n=58\end{array}$ & $\begin{array}{l}\text { - Discussions were rated as: a positive experience in } 72 \% \text {, a } \\
\text { reasonable experience in } 26 \% \text { and a stressful experience in } 2 \% \\
\text { - "One half" formulated wishes for future treatment during the } \\
\text { discussion }\end{array}$ & 1 of 7 \\
\hline \multicolumn{5}{|c|}{ I13. Family/Adolescents - Centered (FACE) ACP intervention } \\
\hline $\begin{array}{l}\text { Jacobs } 2016^{28} \\
\text { USA, }\end{array}$ & $\begin{array}{l}\text { * To report } \\
\text { perspectives } \\
\text { regarding EOL } \\
\text { care } \\
{ }^{*} \text { Survey study } \\
\text { from } \\
\text { intervention } \\
\text { arm RCT }\end{array}$ & $\begin{array}{l}\text { Adolescents with } \\
\text { cancer } \\
n=17 \text { dyads } \\
n=30 \text { clinicians }\end{array}$ & $\begin{array}{l}\text { * Adolescent preferred EOL-discussions in } 75 \% \text { not only 'if dying' and } \\
\text { felt comfortable about talking about death in } 54 \% .12 \% \text { felt not at all } \\
\text { comfortable } \\
\text { * Providers felt in } 83 \% \text { their patients' participation in the study was } \\
\text { helpful to the patients and } 78 \% \text { felt it was helpful to them as providers. } \\
\text { No one thought it was harmful for patients. } 77 \% \text { would refer patients to } \\
\text { an ACP-team }\end{array}$ & 5 of 7 \\
\hline $\begin{array}{l}\text { Lyon } 2017^{35} \\
\text { USA }\end{array}$ & $\begin{array}{l}{ }^{*} \text { To identify } \\
\text { ACP needs } \\
\text { and related } \\
\text { dyad } \\
\text { congruence } \\
\text { * Survey study } \\
\text { from } \\
\text { intervention } \\
\text { arm RCT }\end{array}$ & $\begin{array}{l}\text { Adolescents with } \\
\text { HIV and } \\
\text { surrogates } \\
n=48 \text { dyads }\end{array}$ & $\begin{array}{l}\text { * Adolescent and family concordance: substantial congruence in that } \\
\text { being free from pain and understanding your treatment choices were } \\
\text { very important or important. There was discordance about being off } \\
\text { machines that extend life and when is the best time to bring up EOL } \\
\text { decisions }\end{array}$ & 5 of 7 \\
\hline
\end{tabular}




\begin{tabular}{|c|c|c|c|c|}
\hline $\begin{array}{l}\text { Author, year, } \\
\text { country }\end{array}$ & $\begin{array}{l}\text { Aim and } \\
\text { methods }\end{array}$ & $\begin{array}{l}\text { Population } \\
\text { no. }\end{array}$ & Outcomes & $\begin{array}{c}\text { Risk of Bias } \\
\text { Total score }\end{array}$ \\
\hline \multicolumn{5}{|c|}{ I16. Kitchen Table Discussion } \\
\hline $\begin{array}{l}\text { Ratner } 2001^{3 y} \\
\text { USA } \\
\text { 19 Motivationa }\end{array}$ & $\begin{array}{l}\text { * To determine } \\
\text { effect op ACP } \\
\text { intervention on } \\
\text { home death } \\
\text { * Case series } \\
\text { Stage-Tailored }\end{array}$ & $\begin{array}{l}\text { Patients receiving } \\
\text { home care } \\
\text { services } \\
n=84\end{array}$ & $\begin{array}{l}\text { * } 99 \% \text { agreed to discuss EOL-issues with social worker } \\
\text { * } 64 \% \text { expressed location for EOL-care, which was home in } 85 \% \\
\text { * } 70 \% \text { of the deceased patients dead at home }\end{array}$ & 2 of 7 \\
\hline $\begin{array}{l}\text { Ko } 2016^{42} \\
\text { USA }\end{array}$ & $\begin{array}{l}\text { * To test } \\
\text { feasibility of } \\
\text { the } \\
\text { intervention } \\
\text { * Pre-posttest } \\
\text { structured } \\
\text { questionnaire } \\
\text { study }\end{array}$ & $\begin{array}{l}\text { Low income adults } \\
\text { aged }>60 \text { years } \\
\text { from a supportive } \\
\text { housing facility } \\
n=30\end{array}$ & $\begin{array}{l}\text { * Engagement in EOL discussions: } 33 \% \text { pre-intervention vs. } 47 \% \text { post- } \\
\text { intervention } \\
\text { * Change in behavioral change stages: pre-intervention: } 10 \% \text { planning } \\
\text { stage, } 0 \% \text { active stage. Post-intervention: } 47 \% \text { planning stage, } 23 \% \\
\text { active stage } \\
\text { * Increase of ACP knowledge and positive attitudes towards ACP } \\
\text { (perceived importance and self-efficacy). No differences in negative } \\
\text { attitudes towards ACP } \\
\text { * } 20 \% \text { appointed a DPA and } 83 \% \text { of them had an EOL discussion with } \\
\text { that DPA } \\
\text { * } 23 \% \text { completed an AD post-intervention of which } 86 \% \text { were unsigned } \\
\text { * Most participants were receptive toward the intervention and } \\
\text { considered it beneficial }\end{array}$ & 3 of 7 \\
\hline $\begin{array}{l}\text { 125. Respecting } \\
\text { Hammes } 2010^{60} \\
\text { USA }\end{array}$ & $\begin{array}{l}\text { Choices (RC) } \\
\text { * To determine } \\
\text { outcome } \\
\text { change over } \\
\text { time for RC } \\
\text { * Retrospective } \\
\text { review EHR } \\
\text { and death } \\
\text { certificate data } \\
\text { pre/post } \\
\text { implementation }\end{array}$ & $\begin{array}{l}\text { All adult deaths in } \\
\text { specific region in } \\
\text { two time periods } \\
n=940(T 1 \mathrm{n}= \\
540, \text { T2 } \mathrm{n}=400)\end{array}$ & $\begin{array}{l}\text { * Increased prevalence, availability and specificity of advance care } \\
\text { plans after implementation of RC } \\
{ }^{*} \text { After implementation of RC increase of time period between } \\
\text { completion of AD and death } \\
\text { * Increased consistency between patient preferences and treatment } \\
\text { provided after implementation of RC }\end{array}$ & 3 of 7 \\
\hline
\end{tabular}




\begin{tabular}{|c|c|c|c|c|}
\hline $\begin{array}{l}\text { Author, year, } \\
\text { country }\end{array}$ & $\begin{array}{l}\text { Aim and } \\
\text { methods }\end{array}$ & $\begin{array}{l}\text { Population } \\
\text { no. }\end{array}$ & Outcomes & $\begin{array}{l}\text { Risk of Bias } \\
\text { Total score }\end{array}$ \\
\hline $\begin{array}{l}\text { Boettcher } \\
2014^{48} \\
\text { USA }\end{array}$ & $\begin{array}{l}\text { * To test } \\
\text { feasibility of } \\
\text { telephonic } \\
\text { ACP } \\
{ }^{*} \text { Prospective } \\
\text { descriptive } \\
\text { study data }\end{array}$ & $\begin{array}{l}\text { Frail elderly } \\
\text { patients } \\
\text { with multiple } \\
\text { comorbidities / } \\
\text { advanced disease } \\
\mathrm{n}=576 \\
\text { Facilitators } \\
\mathrm{n}=16\end{array}$ & $\begin{array}{l}\text { * Telephonic ACP resulted in advance directive: in } 55 / 56 \text { discussions } \\
\text { * Increased motivation, confidence and feeling prepared and skilled } \\
\text { among facilitators } 3 \text { months post-intervention. This decreased after } 6 \\
\text { six months }\end{array}$ & 1 of 7 \\
\hline $\begin{array}{l}\text { Hall } 2014^{4 y} \\
\text { USA }\end{array}$ & $\begin{array}{l}\text { * To evaluate } \\
\text { implementation } \\
\text { of RC } \\
\text { * Review EHR } \\
\text { and } \\
\text { questionnaire } \\
\text { study }\end{array}$ & $\begin{array}{l}\text { Residents of } \\
\text { assisted } \\
\text { living facilities with } \\
\text { limited life } \\
\text { expectancy }+ \text { their } \\
\text { health care agents } \\
\text { ( } \mathrm{n}=10 \text { dyads) }\end{array}$ & $\begin{array}{l}\text { * Overall quality of patient-clinician interaction rated as excellent in } \\
90 \% \text {. All residents and } 88 \% \text { of surrogates were sure the clinician knew } \\
\text { their treatment preferences, cared about them as a person, listened to } \\
\text { what they said and gave enough attention } \\
\text { * Number and type of orders in POLST-documents: all residents had a } \\
\text { CPR order and orders on specific medical treatments (intubation, } \\
\text { artificially administered nutrition and hydration, antibiotic use) }\end{array}$ & 3 of 7 \\
\hline $\begin{array}{l}\text { Pecanac } 2016^{\mathrm{b}} \\
\text { USA }\end{array}$ & $\begin{array}{l}{ }^{*} \text { To determine } \\
\text { effect RC on } \\
\text { AD prevalence } \\
\text { an utilization } \\
{ }^{*} \text { Retrospective } \\
\text { review EHR } \\
\text { pre/post } \\
\text { implementation }\end{array}$ & $\begin{array}{l}\text { Medical records of } \\
\text { all decedents from } \\
2005 \text { to } 2010 \text { in a } \\
300 \text {-bed } \\
\text { Midwestern } \\
\text { metropolitan } \\
\text { hospital } \\
(\mathrm{n}=732)\end{array}$ & $\begin{array}{l}\text { * Increased prevalence of AD's in racial or ethnic minorities after } \\
\text { implementation of RC. In whites no difference. } \\
{ }^{*} \text { Consistency of wishes with treatment received was high for all orders, } \\
\text { no difference after implementation of RC. No racial/ethnic differences. }\end{array}$ & 5 of 7 \\
\hline $\begin{array}{l}\text { Hickman } 2016^{y /} \\
\text { USA }\end{array}$ & $\begin{array}{l}\text { * To describe } \\
\text { processes and } \\
\text { preliminary } \\
\text { outcomes } \\
\text { from } \\
\text { implementation } \\
\text { RC-based } \\
\text { ACP } \\
\text { intervention } \\
\text { * Descriptive } \\
\text { study data and } \\
\text { review EHR }\end{array}$ & $\begin{array}{l}\text { Long-stay nursing } \\
\text { home residents } \\
\mathrm{n}=2709\end{array}$ & $\begin{array}{l}\text { * Engagement in ACP discussion: } 27 \% \\
\text { * Change in documented preferences in } 69 \% \text { after ACP discussion(s) } \\
\text { * Review EHR: documentation about ACP conversation present in } 42 \% \text {. } \\
\text { Key reasons for absence of ACP conversations: 'not gotten to the } \\
\text { resident yet' }(57.6 \%) \text {, resident qualified as ineligible }(20.9 \%) \text {, difficulty } \\
\text { scheduling }(9.8 \%)\end{array}$ & 3 of 7 \\
\hline
\end{tabular}




\begin{tabular}{|c|c|c|c|c|}
\hline $\begin{array}{l}\text { Author, year, } \\
\text { country }\end{array}$ & $\begin{array}{l}\text { Aim and } \\
\text { methods }\end{array}$ & $\begin{array}{l}\text { Population } \\
\text { no. }\end{array}$ & Outcomes & $\begin{array}{l}\text { Risk of Bias } \\
\text { Total score }\end{array}$ \\
\hline \multicolumn{5}{|c|}{ I34. Voicing My Choices (VMC) } \\
\hline $\begin{array}{l}\text { Smith } 2017^{74} \\
\text { USA }\end{array}$ & $\begin{array}{l}\text { * To evaluate } \\
\text { the use of } \\
\text { VMC in a } \\
\text { simulated } \\
\text { setting } \\
\text { * Pre-post test } \\
\text { questionnaire } \\
\text { study }\end{array}$ & $\begin{array}{l}\text { Nurse providers } \\
\mathrm{n}=18\end{array}$ & $\begin{array}{l}\text { * Simulation exercise with VMC guide increased self-confidence } \\
\text { regarding initiation of ACP and ability/skills to discuss ACP }\end{array}$ & 3 of 7 \\
\hline $\begin{array}{l}\text { Kazmerski } \\
2016^{75} \\
\text { USA }\end{array}$ & $\begin{array}{l}\text { * To assess } \\
\text { patient and } \\
\text { provider } \\
\text { attitudes and } \\
\text { preferences } \\
\text { regarding VCM }\end{array}$ & $\begin{array}{l}\text { Patients } \leq 22 \text { years } \\
\text { with advanced CF } \\
\mathrm{n}=12 \\
\text { providers } \mathrm{n}=7\end{array}$ & $\begin{array}{l}\text { * Patients felt sessions helpful in } 83 \% \text { and } 58 \% \text { were satisfied with the } \\
\text { session } \\
{ }^{*} \text { One patient felt angry, afraid or overwhelmed during the session, no } \\
\text { one felt ACP was harmful } \\
{ }^{*} \text { Patients felt the VCM guide easy to understand and appropriate for } \\
\text { CF in } 90 \% \\
\text { * Providers felt the guide helpful and easy to understand, easy to use in } \\
\text { leading an ACP discussion and all providers felt it appropriate for } \\
\text { someone with CF }\end{array}$ & 2 of 7 \\
\hline \multicolumn{5}{|c|}{$\begin{array}{l}\text { ACP = advance care planning; AD = Advance Directive; CF = Cystic Fibrosis; DPA = Durable Power of Attorney; EHR = Electronic Health } \\
\text { Record; EOL = End of Life; HIV = Human Immunodeficiency Virus; POLST = Physician Orders for Life Sustaining Treatment; RCT = } \\
\text { Randomized Controlled Trial; }\end{array}$} \\
\hline
\end{tabular}


Table 6. Evidence from mixed-method studies

\begin{tabular}{|c|c|c|c|c|c|c|}
\hline \multirow{2}{*}{$\begin{array}{l}\text { Author, year, } \\
\text { country }\end{array}$} & \multirow{2}{*}{$\begin{array}{l}\text { Aim and } \\
\text { methods }\end{array}$} & \multirow{2}{*}{$\begin{array}{l}\text { Population } \\
\text { no. }\end{array}$} & \multicolumn{2}{|l|}{ Outcomes } & \multirow{2}{*}{$\begin{array}{l}\text { Risk of } \\
\text { Bias } \\
\text { Total } \\
\text { score }\end{array}$} & \multirow{2}{*}{$\begin{array}{c}\text { Quality of } \\
\text { reporting } \\
\text { Total } \\
\text { score }\end{array}$} \\
\hline & & & Quantitative data & Qualitative data & & \\
\hline \multicolumn{7}{|c|}{ I8. ACP Group Medical Visit } \\
\hline $\begin{array}{l}\text { Lum } 2016^{\angle L} \\
\text { USA }\end{array}$ & $\begin{array}{l}\text { * To report } \\
\text { feasibility of } \\
\text { Group Medical } \\
\text { Visits } \\
\text { * Electronic } \\
\text { patients } \\
\text { reports and } \\
\text { content } \\
\text { analysis group } \\
\text { visits }\end{array}$ & $\begin{array}{l}\text { Geriatric patients } \\
\text { receiving primary } \\
\text { care } \\
n=32\end{array}$ & $\begin{array}{l}{ }^{*} \text { Post-intervention } 75 \% \text { had } \\
\text { an ACP conversation with } \\
\text { surrogate and } 41 \% \text { felt } \\
\text { confident loved ones know } \\
\text { their wishes } \\
\text { * Groups Visits were rated } \\
\text { better for ACP talk than usual } \\
\text { visits and gave useful } \\
\text { information } \\
\text { * } 80 \% \text { felt comfortable about } \\
\text { ACP-talk in groups and } 70 \% \\
\text { stated talking with others } \\
\text { about ACP was helpful }\end{array}$ & $\begin{array}{l}\text { * Patients shared personal } \\
\text { values and challenges } \\
\text { related to ACP } \\
\text { * Patients initiated group } \\
\text { discussions of a broad } \\
\text { range of ACP topics } \\
\text { beyond topics raised by } \\
\text { facilitators }\end{array}$ & 1 of 7 & $\begin{array}{c}18.5 \text { of } \\
32\end{array}$ \\
\hline $\begin{array}{l}\text { Lum } 2017^{23} \\
\text { USA }\end{array}$ & $\begin{array}{l}\text { * To report } \\
\text { feasibility of } \\
\text { Group Medical } \\
\text { Visits } \\
\text { * Chart review } \\
\text { and content } \\
\text { analysis group } \\
\text { visits }\end{array}$ & $\begin{array}{l}\text { Patients } \geq 65 \\
\text { years in primary } \\
\text { care } \\
n=118\end{array}$ & $\begin{array}{l}\text { * } 82 \% \text { completed both } \\
\text { intervention sessions } \\
\text { * Increased documentation of } \\
\text { surrogate decision maker in } \\
\text { EHR over study period } \\
\text { * Increased amount of ACP } \\
\text { documents in EHR over study } \\
\text { period }\end{array}$ & $\begin{array}{l}\text { * Key reasons for } \\
\text { participating: recognition need } \\
\text { for } \mathrm{ACP} \text {, recommendation by } \\
\text { primary care providers, } \\
\text { curiosity about the topic }\end{array}$ & 3 of 7 & $\begin{array}{c}14.5 \text { of } \\
32\end{array}$ \\
\hline
\end{tabular}




\begin{tabular}{|c|c|c|c|c|c|c|}
\hline \multirow{2}{*}{$\begin{array}{l}\text { Author, year, } \\
\text { country }\end{array}$} & \multirow{2}{*}{$\begin{array}{l}\text { Aim and } \\
\text { methods }\end{array}$} & \multirow{2}{*}{$\begin{array}{l}\text { Population } \\
\text { no. }\end{array}$} & \multicolumn{2}{|l|}{ Outcomes } & \multirow{2}{*}{$\begin{array}{c}\text { Risk of } \\
\text { Bias } \\
\text { Total score }\end{array}$} & \multirow{2}{*}{$\begin{array}{c}\text { Quality of } \\
\text { reporting } \\
\text { Total } \\
\text { score }\end{array}$} \\
\hline & & & Quantitative data & Qualitative data & & \\
\hline \multicolumn{7}{|c|}{ 112. End of Life Preferences Interview (ELPI) } \\
\hline $\begin{array}{l}\text { Borreani } 2008^{26} \\
\text { Italy }\end{array}$ & $\begin{array}{l}{ }^{*} \text { To pretest } \\
\text { feasibility of } \\
\text { ELPI } \\
{ }^{*} \text { Descriptive } \\
\text { study data and } \\
\text { semi } \\
\text { structured } \\
\text { interviews } \\
\text { physicians }\end{array}$ & $\begin{array}{l}\text { Palliative care } \\
\text { patients } \\
n=12 \\
\text { Physicians } \\
n=3\end{array}$ & $\begin{array}{l}{ }^{*} \text { Physicians proposed } \mathrm{ACP} \\
\text { in } 27 \% \text { of eligible patients. } \\
\text { Reasons refusal to } \\
\text { propose: finding right time } \\
\text { and moment } \\
{ }^{*} \text { Completion of first part } \\
\text { intervention: } 67 \% \text {, } \\
\text { completion of full } \\
\text { intervention: } 33 \%\end{array}$ & $\begin{array}{l}\text { Physicians pointed out that } \\
\text { the condition necessary to } \\
\text { propose the interview to the } \\
\text { patient is his/her awareness } \\
\text { about the prognosis. } \\
\text { Physicians were comfortable } \\
\text { about confronting proposed } \\
\text { themes, but fear of triggering } \\
\text { intense emotions exists. } \\
\text { ELPI is stimulus for } \\
\text { conversation but somewhat } \\
\text { direct with limited possibilities } \\
\text { for adaptation }\end{array}$ & 0 of 7 & 8.5 of 32 \\
\hline $\begin{array}{l}\text { Borreani } 2012^{2 \prime} \\
\text { Italy, }\end{array}$ & $\begin{array}{l}\text { * To test } \\
\text { feasibility of } \\
\text { ELPI } \\
{ }^{*} \text { Descriptive } \\
\text { study data and } \\
\text { open-response } \\
\text { questionnaire }\end{array}$ & $\begin{array}{l}\text { Advance cancer } \\
\text { patients in } \\
\text { palliative care } \\
\text { setting } \\
\mathrm{n}=91 \\
\text { Physicians } \\
\mathrm{n}=23\end{array}$ & $\begin{array}{l}\text { * Physicians proposed ACP } \\
\text { in } 58 \% \text { of eligible patients. } \\
\text { Reasons refusal to } \\
\text { propose: logistic- } \\
\text { organizational reasons, } \\
\text { poor physical condition of } \\
\text { patient, other reasons } \\
\text { * Completion of full } \\
\text { intervention: } 42 \%\end{array}$ & $\begin{array}{l}{ }^{*} \text { Factors influencing } \\
\text { communication: patient and } \\
\text { family readiness, physician } \\
\text { willingness, skills and team } \\
\text { support, sufficient time and } \\
\text { adequate timing }\end{array}$ & 0 of 7 & 12 of 32 \\
\hline
\end{tabular}




\begin{tabular}{|c|c|c|c|c|c|c|}
\hline \multirow{2}{*}{$\begin{array}{l}\text { Author, year, } \\
\text { country }\end{array}$} & \multirow{2}{*}{$\begin{array}{l}\text { Aim and } \\
\text { methods }\end{array}$} & \multirow{2}{*}{$\begin{array}{l}\text { Population } \\
\text { no. }\end{array}$} & \multicolumn{2}{|l|}{ Outcomes } & \multirow{2}{*}{$\begin{array}{c}\text { Risk of } \\
\text { Bias } \\
\text { Total score }\end{array}$} & \multirow{2}{*}{$\begin{array}{c}\text { Quality of } \\
\text { reporting } \\
\text { Total } \\
\text { score }\end{array}$} \\
\hline & & & Quantitative data & Qualitative data & & \\
\hline \multicolumn{7}{|c|}{ I20. Palliative Care Program (PCP) } \\
\hline $\begin{array}{l}\text { Chan } 2014^{43} \\
\text { China }\end{array}$ & $\begin{array}{l}\text { * To report } \\
\text { effectiveness } \\
\text { of PCP } \\
\text { * Pre-posttest } \\
\text { questionnaire } \\
\text { study and } \\
\text { semi- } \\
\text { structured } \\
\text { interview study }\end{array}$ & $\begin{array}{l}\text { Home care } \\
\text { patients with life- } \\
\text { limiting disease } \\
n=108 \\
\text { (quantitative } \\
\text { outcomes) } \\
n=14 \text { (qualitative } \\
\text { outcomes) }\end{array}$ & $\begin{array}{l}\text { * Improved physical quality } \\
\text { of life and decreased need } \\
\text { for social support } \\
\text { * Improved understanding } \\
\text { treatment and goals } \\
\text { * Family satisfaction tended } \\
\text { to improve } \\
{ }^{*} \text { Initial decrease in hospital } \\
\text { use, reduced effect after } \\
\text { three months } \\
\text { * Initial increase in } \\
\text { completion AD/living } \\
\text { will/DNR-order, reduced } \\
\text { effect after } 3 \text { months }\end{array}$ & $\begin{array}{l}\text { * Improved communication of } \\
\text { treatment plans and after- } \\
\text { death arrangement } \\
{ }^{*} \text { Relief of fear } \\
\text { * Improvement in emotional } \\
\text { support } \\
\text { * Improvement of symptom } \\
\text { management by home care } \\
\text { nurses }\end{array}$ & 1 of 7 & 15 of 32 \\
\hline \multicolumn{7}{|c|}{ I21. Patient Preferences About Serious IIIness Instrument (PASI) } \\
\hline $\begin{array}{l}\text { Whitehead } \\
2016^{44} \\
\text { USA }\end{array}$ & $\begin{array}{l}{ }^{*} \text { To } \\
\text { understand } \\
\text { effectiveness } \\
\text { of PASI and } \\
\text { report on } \\
\text { experiences in } \\
\text { EOL } \\
\text { conversations } \\
\text { * Survey study } \\
\text { and } \\
\text { focusgroup }\end{array}$ & $\begin{array}{l}\text { Nurse practitioners } \\
\mathrm{n}=47 \\
\text { (quantitative } \\
\text { outcomes) } \\
\mathrm{n}=13\end{array}$ & $\begin{array}{l}\text { * } 68 \% \text { were currently having } \\
\text { conversations about EOL } \\
\text { preferences with patients. } \\
32 \% \text { did not, but was } \\
\text { interested in having them } \\
{ }^{*} 89 \% \text { agreed to be } \\
\text { comfortable having EOL } \\
\text { conversations with patients }\end{array}$ & $\begin{array}{l}\text { * Formal training to conduct } \\
\text { EOL conversations needed } \\
\text { * PASI could improve care, is } \\
\text { useful and can identify a } \\
\text { patient's primary concern }\end{array}$ & 1 of 7 & 17 of 32 \\
\hline
\end{tabular}




\begin{tabular}{|c|c|c|c|c|c|c|}
\hline \multirow{2}{*}{$\begin{array}{l}\text { Author, year, } \\
\text { country }\end{array}$} & \multirow{2}{*}{$\begin{array}{l}\text { Aim and } \\
\text { methods }\end{array}$} & \multirow{2}{*}{$\begin{array}{l}\text { Population } \\
\text { no. }\end{array}$} & \multicolumn{2}{|l|}{ Outcomes } & \multirow{2}{*}{$\begin{array}{c}\text { Risk of } \\
\text { Bias } \\
\text { Total score }\end{array}$} & \multirow{2}{*}{$\begin{array}{l}\text { Quality of } \\
\text { reporting } \\
\text { Total } \\
\text { score }\end{array}$} \\
\hline & & & Quantitative data & Qualitative data & & \\
\hline \multicolumn{7}{|c|}{ I25. Respecting Choices (RC) } \\
\hline $\begin{array}{l}\text { Rocque } 2017^{5 y} \\
\text { USA }\end{array}$ & $\begin{array}{l}\text { * To evaluate } \\
\text { implementation } \\
\text { of lay } \\
\text { navigator-led } \\
\text { RC-based } \\
\text { ACP } \\
\text { * Review EHR, } \\
\text { claims data, } \\
\text { questionnaire } \\
\text { and semi } \\
\text { structured } \\
\text { interviews }\end{array}$ & $\begin{array}{l}\text { Lay patient } \\
\text { navigators } n=26 \\
\text { Patients from } 12 \\
\text { cancer centers } n= \\
8704\end{array}$ & $\begin{array}{l}\text { * ACP conversations were } \\
\text { initiated in } 15 \% \text { of patients } \\
\text { and } 36 \% \text { completed the } \\
\text { conversation } \\
\text { * Navigators self-efficacy } \\
\text { increased during the study } \\
\text { * Lower hospitalization } \\
\text { rates in patient engaged in } \\
\text { ACP discussions }\end{array}$ & $\begin{array}{l}\text { * Navigator-reported } \\
\text { facilitators for implantation } \\
\text { included physician buy-in, } \\
\text { patient readiness, and prior } \\
\text { ACP experience; barriers } \\
\text { included space limitations, } \\
\text { identifying the "right" time to } \\
\text { start conversations, and } \\
\text { personal discomfort } \\
\text { discussing EOL }\end{array}$ & 1 of 7 & 15 of 32 \\
\hline \multicolumn{7}{|c|}{ I26. Scripted Nurse pre-Ventricular Assisted Device Visits } \\
\hline $\begin{array}{l}\text { O'Connor } \\
2016^{63} \\
\text { USA }\end{array}$ & $\begin{array}{l}\text { * To evaluate } \\
\text { ACP program } \\
\text { * Prospective } \\
\text { descriptive } \\
\text { study data and } \\
\text { interviews }\end{array}$ & $\begin{array}{l}\text { Patients for VAD- } \\
\text { evaluation } \\
n=37 \\
\text { VAD team } \\
\text { members } \\
n=4\end{array}$ & $\begin{array}{l}\text { * All eligible patients agreed } \\
\text { to the visit and completed } \\
\text { the entire scripted visit }\end{array}$ & $\begin{array}{l}\text { *VAD team uniformly positive, } \\
\text { declared visits as 'valuable' }\end{array}$ & 2 of 7 & 3 of 32 \\
\hline \multicolumn{7}{|c|}{ I28. Sharing Patient's IIIness Representations to Increase Trust (SPIRIT) } \\
\hline $\begin{array}{l}\text { Song } 2009^{\circ /} \\
\text { USA }\end{array}$ & $\begin{array}{l}\text { * To determine } \\
\text { feasibility, } \\
\text { acceptability } \\
\text { and effects of } \\
\text { SPIRIT vs } \\
\text { usual care } \\
\text { * RCT, pretest- } \\
\text { posttest, } \\
\text { questionnaires } \\
\text { and semi- } \\
\text { structured } \\
\text { interviews }\end{array}$ & $\begin{array}{l}\text { African Americans } \\
\text { with ESRD } \\
\mathrm{n}=58 \text { dyads } \\
\text { (l: } 29 \text { C: } 29) \\
\text { Bereaved } \\
\text { surrogates } \\
\mathrm{n}=4 \text { (I: } 4 \text { C: } 0 \text { ) }\end{array}$ & $\begin{array}{l}\text { * Increase in quality of } \\
\text { communication and dyad } \\
\text { congruence } \\
{ }^{*} \text { No difference in decisional } \\
\text { conflict, psychosocial and } \\
\text { spiritual wellbeing and } \\
\text { surrogate's decision making } \\
\text { confidence }\end{array}$ & $\begin{array}{l}\text { * ACP made it easy to open } \\
\text { up and share feelings. ACP } \\
\text { was emotional but profitable } \\
\text { * SPIRIT increased } \\
\text { knowledge and insight in } \\
\text { values, LST and family } \\
\text { dynamics. Patient-family } \\
\text { relation was strengthened } \\
\text { * Three bereaved surrogates } \\
\text { made EOL decisions for a } \\
\text { patient, they were well } \\
\text { prepared, and SPIRIT helped } \\
\text { in decision-making. }\end{array}$ & 3 of 7 & 17 of 32 \\
\hline
\end{tabular}




\begin{tabular}{|c|c|c|c|c|c|c|}
\hline \multirow{2}{*}{$\begin{array}{l}\text { Author, year, } \\
\text { country }\end{array}$} & \multirow{2}{*}{$\begin{array}{l}\text { Aim and } \\
\text { methods }\end{array}$} & \multirow{2}{*}{$\begin{array}{l}\text { Population } \\
\text { no. }\end{array}$} & \multicolumn{2}{|l|}{ Outcomes } & \multirow{2}{*}{$\begin{array}{c}\text { Risk of } \\
\text { Bias } \\
\text { Total score }\end{array}$} & \multirow{2}{*}{$\begin{array}{l}\text { Quality of } \\
\text { reporting } \\
\text { Total } \\
\text { score }\end{array}$} \\
\hline & & & Quantitative data & Qualitative data & & \\
\hline $\begin{array}{l}\text { Metzger } 2016^{65} \\
\text { USA }\end{array}$ & $\begin{array}{l}\text { * To examine } \\
\text { feasibility, } \\
\text { acceptability } \\
\text { and } \\
\text { preliminary } \\
\text { effects of } \\
\text { SPIRIT-HF vs } \\
\text { usual care } \\
\text { * RCT, } \\
\text { descriptive } \\
\text { study data, } \\
\text { questionnaires } \\
\text { and semi } \\
\text { structured } \\
\text { interviews }\end{array}$ & $\begin{array}{l}\text { Heart failure } \\
\text { patients with LVAD } \\
n=29 \text { dyads (I: } 14 \\
\text { C: } 15 \text { ) }\end{array}$ & $\begin{array}{l}\text { * } 21 \% \text { of eligible patients } \\
\text { declined } \\
{ }^{*} \text { Increase in dyad } \\
\text { congruence } \\
\text { * No difference in decisional } \\
\text { conflict and surrogate DM } \\
\text { confidence }\end{array}$ & $\begin{array}{l}\text { * Twenty-five participants had } \\
\text { a positive experience, } 3 \\
\text { mixed } \\
\text { * All participants declared } \\
\text { conversations like SPIRIT-HF } \\
\text { very important } \\
\text { * Nearly all declared these } \\
\text { conversations should be part } \\
\text { of patient care } \\
\text { * Benefits: being able to } \\
\text { express preferences for EOL- } \\
\text { care; learning about EOL- } \\
\text { scenario's and DM; being } \\
\text { prepared for 'what ifs' } \\
\text { * Most common barriers: } \\
\text { timing and scheduling }\end{array}$ & 3 of 7 & 14.5 of 32 \\
\hline \multicolumn{7}{|c|}{ I31. Thinking Ahead Project (TAP) } \\
\hline $\begin{array}{l}\text { Huang } 2016^{\prime 2} \\
\text { USA }\end{array}$ & $\begin{array}{l}\text { * To examine } \\
\text { the feasibility } \\
\text { of TAP vs } \\
\text { provision of } \\
\text { education } \\
\text { materials } \\
\text { * RCT, } \\
\text { descriptive } \\
\text { study data, } \\
\text { questionnaires } \\
\text { and semi } \\
\text { structured } \\
\text { interviews }\end{array}$ & $\begin{array}{l}\text { Community- } \\
\text { dwelling African } \\
\text { Americans } \\
\mathrm{n}=30 \text { (I: } 15 \text { C: } 15 \text { ) } \\
\text { Waitlist controls } \\
\text { received } \\
\text { intervention after } \\
\text { waiting time } \\
\mathrm{n}=12\end{array}$ & $\begin{array}{l}\text { * Increased knowledge of } \\
\text { AD's in intervention group } \\
\text { * No difference in } \\
\text { satisfaction with } \\
\text { intervention or intention to } \\
\text { complete AD }\end{array}$ & $\begin{array}{l}\text { * Participants noted that the } \\
\text { TAP intervention was "very } \\
\text { well covered" and "helped to } \\
\text { make ACP simpler to } \\
\text { understand." } \\
\text { * Low engagement in ACP } \\
\text { among African Americans } \\
\text { due to lack of information and } \\
\text { patient education resources } \\
\text { * Participants expressed a } \\
\text { strong desire to learn more } \\
\text { about ACP and have } \\
\text { education or information } \\
\text { delivered to the local } \\
\text { community to meet their } \\
\text { health literacy needs }\end{array}$ & 1 of 7 & 15 of 32 \\
\hline $\begin{array}{l}\mathrm{ACP}=\mathrm{Advanc} \\
\text { Disease; } \mathrm{DM}=\end{array}$ & $\begin{array}{l}\text { re Planning; } A \\
\text { ision Making; } \\
\text { sisted Device }\end{array}$ & $\begin{array}{l}\text { Advance Directiv } \\
=\text { Do-Not-Resus }\end{array}$ & $\begin{array}{l}\mathrm{AR}=\text { Electronic Health } \\
; \quad \text { LST = Life Sustaini }\end{array}$ & $\begin{array}{l}\mathrm{d} ; \mathrm{EOL}=\mathrm{End} \text { of Life; ESRD = } \\
\text { tment; RCT = Randomized Cor }\end{array}$ & $\begin{array}{l}\text { Stage Re } \\
\text { lled Trial; }\end{array}$ & \\
\hline
\end{tabular}




\section{Discussion}

\section{Findings}

To the best of our knowledge, this is the first systematic review evaluating the content, feasibility and effectiveness of interventions based on a conversation guide to support health care professionals in ACP conversations. Thirty-four unique interventions were identified. Most interventions lacked a comprehensive theoretical underpinning. A thematic analysis of identified conversation guides revealed four subsequent phases of ACP-conversations: preparation, initiation, exploration and action. The explorative phase formed the core part of the conversation guides discussing illness views, views on living well, views on death and dying, psychosocial wellbeing, treatment preferences and views on involvement of others in care and decision making. The connection between the distinct phases of the conversation was less well described in most interventions. How prior phases inform the action phase and subsequent steps in the ACP process remains unclear. Although guided ACP conversations seem to increase dyad congruence and ACP documentation rates the evidence for effects on future medical care and preferences-concordant care is limited.

High-quality research answering underlying key questions about the process and effectiveness of ACP is still in its infancy. The evidence identified in this review is concentrated around a few interventions and does not enable comparison between individual interventions or conversation guides. It remains unclear which conversation themes are most helpful in ACP.

Several factors complicate research about ACP interventions. First, these interventions are often complex interventions, consisting of multiple interacting components, which makes their evaluation more challenging. ${ }^{98}$ In our review, this was reflected by the heterogeneity of intervention descriptions, study designs, outcome measures and study quality. Besides that, the absence of details about the intervention in manuscripts is a generally acknowledged phenomenon. ${ }^{99}$ More transparency about the content of interventions is a first step towards more insight in ACP interventions.

Second, the evaluation of ACP interventions is mainly based on process measures like knowledge about $\mathrm{ACP}$, documentation rates, discussion rates, quality of communication and 
dyad congruence. Although these parameters might influence the effectiveness of ACP interventions, improvement of process factors does not ensure achievement of the final goal of ACP, which is 'to help ensure that people receive medical care that is consistent with their values, goals and preferences during serious and chronic illness' ${ }^{100}$.

Third, an underlying rationale for the characteristics of the interventions and content of the guides was often lacking. The practice-based design of ACP conversation guides complicates the understanding of the communicative process and illustrates the need for research to reveal underlying communicative, relational and behavioral principles. ${ }^{101,102}$

Our review shows there is a large body of existing interventions. The growing interest in ACP should therefore not result in the development of more new interventions, but in deeper evaluation of current strategies to understand which (components of) ACP interventions are effective and why.

The key question remains how exploration of patient's perspectives can be used to inform future medical decision making and care. The translation of preferences and values into goals of care and treatment decisions requires further identification of essential content of the conversation and the role, attitude and position of the conversation partners. The professional might have a predominantly initiating, facilitating and explorative role, but providing guidance to the patient based on the patient's values and preferences on the one side and medical expertise on the other side might be another task of the health care professional. ${ }^{6,80,94}$ This 'skilled companionship' might be essential to strengthen the translation of values, life goals and preferences into corresponding medical care in different stages of life and illness. Content analysis of ACP conversations and thorough, longitudinal evaluation of patient's perspectives on the value of ACP might help in understanding this complex, individualized process.

\section{Strengths and Limitations}

This systematic review provides a thorough overview of the body of knowledge regarding multiple dimensions of ACP interventions based on conversation guides. Instead of a focus on 
outcome data, it evaluates the characteristics of the interventions and the content of the conversation guides as well.

Our review has some limitations. First, although 34 interventions were retrieved, the identification of articles describing scripted conversation guides might not be complete. Although corresponding authors were contacted in order to obtain more details on the intervention characteristics, studies might have been excluded inaccurately because of lack of insight into the conversation guide. Second, non-profit organizations, patient organizations and governmental initiatives respond to the growing attention for ACP with the development of ACP-tools. These tools are often only described in grey literature and were not covered by our search, but might play a role in daily medical care

Third, our review did not include interventions based on websites, patient-held workbooks, patient-question-prompt-lists and games. ${ }^{103-105}$ These interventions may result in similar ACP conversations compared to interventions based on a scripted conversation guide. The choice not to evaluate other approaches limits the evaluation of the added value of a scripted conversation guide.

\section{Conclusions}

Scripted ACP conversation guides structure ACP discussions in four phases: preparation, initiation, exploration and action. Exploration of patient's views on illness, living well, EOL-issues and decision making form the core part of ACP conversation guides. This exploration might support the professional to align medical care with patients' preferences. Research evaluating the relation between guided ACP conversations and preferences-concordant care is limited. Further research needs to reveal underlying theoretical and communicative principles to determine which elements are essential to connect exploration of values and preferences with future medical care. 


\section{References}

1. IOM. Dying in America: Improving Quality and Honoring Individual Preferences Near the End of Life. Washington, DC: National Academies Press; 2015.

2. Rietjens JAC, Sudore PRL, Connolly M, et al. Review Definition and recommendations for advance care planning: an international consensus supported by the European Association for Palliative Care. Lancet Oncol. 2017;18(9):e543-e551.

3. Brinkman-Stoppelenburg A, Rietjens JAC, van der Heide A. The effects of advance care planning on end-of-life care: A systematic review. Palliat Med. 2014;28(8):1000-1025.

4. Detering $K M$, Hancock $A D$, Reade $M C$, Silvester $W$. The impact of advance care planning on end of life care in elderly patients: randomised controlled trial. BMJ. 2010;340:c1345.

5. Houben CHM, Spruit MA, Groenen MTJ, Wouters EFM, Janssen DJA. Efficacy of Advance Care Planning: A Systematic Review and Meta-Analysis. J Am Med Dir Assoc. 2014;15(7):477-489.

6. Bernacki RE, Block SD. Communication About Serious Illness Care Goals A Review and Synthesis of Best Practices. Jama Intern Med. 2014;174(12):1994-2003.

7. De Vleminck A, Houttekier D, Deliens L, Vander Stichele R, Pardon K. Development of a complex intervention to support the initiation of advance care planning by general practitioners in patients at risk of deteriorating or dying: a phase 0-1 study. BMC Palliat Care. 2016;15(1):17.

8. Gilissen J, Pivodic L, Smets T, et al. International Journal of Nursing Studies Preconditions for successful advance care planning in nursing homes: A systematic review. Int J Nurs Stud. 2017;66:47-59.

9. Moher D, Liberati A, Tetzlaff J, Altman DG, Group TP. Preferred Reporting Items for Systematic Reviews and Meta-Analyses: The PRISMA Statement. 2009;6(7).

10. Schulz R, Czaja SJ, McKay JR, Ory MG BS. Intervention Taxonomy (ITAX): Describing Essential Features of Interventions. Am J Heal Behav. 2010;34(6):811-821.

11. Higgins J, Green S. Cochrane Handbook for Systematic Reviews of Interventions. Version 5. The Cochrane Collaboration; 2011. Publisher location: London, United Kingdom.

http://handbook.cochrane.org. (accessed: 1 May 2017)

12. Tong A, Sainsbury P, Craig J. Consolidated criteria for reporting qualitative research ( COREQ ): a 32-item checklist for interviews and focus groups. Int J Qual Heal Care. 2007;19(6):349-357.

13. Dixon-Woods M, Shaw RL, Agarwal S, Smith JA. The problem of appraising qualitative research. Qual Saf Heal Care. 2004;13(3):223-225.

14. Popay J, Roberts H, Sowden A, et al. Guidance on the Conduct of Narrative Synthesis in Systematic Reviews A Product from the ESRC Methods Programme.; Institute for Health Research London, United Kingdom; 2006. 
15. Thomas J, Harden A. Methods for the thematic synthesis of qualitative research in systematic reviews. BMC Med Res Methodol. 2008;10:1-10.

16. Edwards LA, Jarrell JA, Bui C, Cabrera AG. Improving outpatient advance care planning for adults with congenital or pediatric heart disease followed in a pediatric heart failure and transplant clinic. Congenit Heart Dis. 2018;(December 2017):1-7.

17. Simpson AC. An opportunity to care? preliminary insights from a qualitative study on advance care planning in advanced COPD. Prog Palliat Care. 2011;19(5):243-253.

18. Simpson C. Advance care planning in COPD: Care versus "code status." Chron Respir Dis. 2012;9(3):193-204.

19. Poppe M, Burleigh S, Banerjee S. Qualitative Evaluation of Advanced Care Planning in Early Dementia (ACP-ED). PLoS One. 2013;8(4).

20. Friis P, Forde R. Advance care planning discussions with geriatric patients. Tidsskr Den Nor Laegeforening. 2015;135(3):233-235.

21. Horne G, Seymour J, Shepherd K. Advance care planning for patients with inoperable lung cancer. Int J Palliat Nurs. 2006;12(4):172-178.

22. Lum HD, Jones J, Matlock DD, et al. Advance Care Planning Meets Group Medical Visits: The Feasibility of Promoting Conversations. Ann Fam Med. 2016;14(2):125-132.

23. Lum HD, Sudore RL, Matlock DD, et al. A Group Visit Initiative Improves Advance Care Planning Documentation among Older Adults in Primary Care. J Am Board Fam Med. 2017;30(4):480-490.

24. Au DH, Udris EM, Engelberg RA, et al. A Randomized Trial to Improve Communication About Endof-Life Care Among Patients With COPD. Chest. 2012;141(3):726-735.

25. Reinke LF, Feemster LC, McDowell J, et al. The long term impact of an end-of-life communication intervention among veterans with COPD. Hear Lung J Acute Crit Care. 2017;46(1):30-34.

26. Borreani C, Brunelli C, Miccinesi G, et al. Eliciting Individual Preferences About Death: Development of the End-of-Life Preferences Interview. J Pain Symptom Manage. 2008;36(4):335-350.

27. Borreani C, Brunelli C, Bianchi E, Piva L, Moro C, Miccinesi G. Talking about end-of-life preferences with advanced cancer patients: Factors influencing feasibility. J Pain Symptom Manage. 2012;43(4):739-746.

28. Jacobs S, Perez J, Cheng YI, Sill A, Wang J, Lyon ME. Adolescent end of life preferences and congruence with their parents' preferences: Results of a survey of adolescents with cancer. Pediatr Blood Cancer. 2015;62(4):710-714.

29. Lyon ME, Garvie P a, Briggs L, He J, McCarter R, D'Angelo L. Development, feasibility, and acceptability of the Family/Adolescent-Centered (FACE) Advance Care Planning intervention for adolescents with HIV. J Palliat Med. 2009;12(4):363-372. 
30. Lyon ME, Garvie P a, McCarter R, Briggs L, He J, D'Angelo L. Who Will Speak for Me? Improving End-of-Life Decision-Making for Adolescents With HIV and Their Families. Pediatrics. 2009;123(2):e199-e206.

31. Lyon ME, Garvie PA, Briggs L, et al. Is it safe? Talking to teens with HIV/AIDS about death and dying: a 3-month evaluation of Family Centered Advance Care (FACE) planning - anxiety, depression, quality of life. HIV/AIDS Res Palliat Care. 2010;2:27-37.

32. Lyon ME, Garvie PA, Kao E, et al. Spirituality in HIV-infected adolescents and their families: FAmily CEntered (FACE) advance care planning and medication adherence. J Adolesc Heal. 2011;48(6):633636.

33. Lyon ME, Jacobs S, Briggs L, Cheng YI, Wang J. Family-centered advance care planning for teens with cancer. JAMA Pediatr. 2013;167(5):460-467.

34. Lyon ME, Jacobs S, Briggs L, Cheng YI, Wang J. A longitudinal, randomized, controlled trial of advance care planning for teens with cancer: anxiety, depression, quality of life, advance directives, spirituality. J Adolesc Heal. 2014;54(6):710-717.

35. Lyon $\mathrm{ME}$, $\mathrm{D}^{\prime}$ Angelo $\amalg$, Dallas $\mathrm{RH}$, et al. A randomized clinical trial of adolescents with HIV/AIDS: pediatric advance care planning. AIDS Care - Psychol Socio-Medical Asp AIDS/HIV. 2017;29(10):1287-1296.

36. Lyon ME, Dallas RH, Garvie PA, et al. Paediatric advance care planning survey: a cross-sectional examination of congruence and discordance between adolescents with HIV/AIDS and their families. BMJ Support Palliat Care. 2017;(2):bmjspcare-2016-001224.

37. Dallas $\mathrm{RH}$, Kimmel A, Wilkins $\mathrm{ML}$, et al. Acceptability of Family-Centered Advanced Care Planning for Adolescents With HIV. Pediatrics. 2016;138(6):e20161854-e20161854.

38. Bekelman DB, Johnson-Koenke R, Ahluwalia SC, Walling AM, Peterson J, Sudore RL. Development and Feasibility of a Structured Goals of Care Communication Guide. J Palliat Med. 2017;20(9):jpm.2016.0383.

39. Ratner E, Norlander L, McSteen K. Death at home following a targeted advance-care planning process at home: the kitchen table discussion. J Am Geriatr Soc. 2001;49(6):778-781.

40. Chan HYL, Pang SMC. Let me talk - an advance care planning programme for frail nursing home residents. J Clin Nurs. 2010;19(21-22):3073-3084.

41. Schwartz C, Lennes I, Hammes B, Lapham C, Bottner W, Ma Y. Honing an advance care planning intervention using qualitative analysis: the Living Well interview. J Palliat Med. 2003;6(4):593-603.

42. Ko E, Hohman M, Lee J, Ngo A-N, Woodruff SI. Feasibility and Acceptability of a Brief Motivational Stage-Tailored Intervention to Advance Care Planning. Am J Hosp Palliat Med. 2016;33(9):834-842.

43. Chan $\mathrm{CWH}$, Chui YY, Chair SY, et al. The evaluation of a palliative care programme for people suffering from life-limiting diseases. J Clin Nurs. 2014;23(1-2):113-123. 
44. Whitehead PB, Ramalingam N, Carter KF, Katz K, Harden S. Nurse Practitioners' Perspectives on the Patient Preferences About Serious Illness Instrument. J Hosp Palliat Nurs. 2016;18(4):332-341.

45. Fischer SM, Cervantes L, Fink RM, Kutner JS. Apoyo con Carino: a pilot randomized controlled trial of a patient navigator intervention to improve palliative care outcomes for Latinos with serious illness. J Pain Symptom Manag. 2015;49(4):657-665.

46. Hilgeman MM, Allen RS, Snow AL, Durkin DW, Decoster J, Burgio L. Preserving Identity and Planning for Advance Care (PIPAC): Preliminary outcomes from a patient-centered intervention for individuals with mild dementia. Aging Ment Heal. 2014;18(4):411-424.

47. Briggs La., Kirchhoff KT, Hammes BJ, Song MK, Colvin ER. Patient-centered advance care planning in special patient populations: A pilot study. J Prof Nurs. 2004;20(1):47-58.

48. Boettcher I, Turner R, Briggs L. Telephonic advance care planning facilitated by health plan case managers. Palliat Support Care. 2015;13(3):795-800.

49. Hall NA, Jenson CE. Implementation of a Facilitated Advance Care Planning Process in an Assisted Living Facility. J Hosp Palliat Nurs. 2014;16(2):113-119.

50. Song MK, Donovan HS, Piraino BM, et al. Effects of an intervention to improve communication about end-of-life care among African Americans with chronic kidney disease. Appl Nurs Res. 2010;23(2):65-72.

51. Der Schmitten JI, Lex K, Mellert C, RothÄrmel S, Wegscheider K, Marckmann G. Implementing an advance care planning program in german nursing homes. Dtsch Arztebl Int. 2014;111(4):50-57.

52. Kirchhoff KT, Hammes BJ, Kehl KA, Briggs LA, Brown RL. Effect of a Disease-Specific Planning Intervention on Surrogate Understanding of Patient Goals for Future Medical Treatment. J Am Geriatr Soc. 2010;58(7):1233-1240.

53. Kirchhoff KT, Hammes BJ, Kehl K a., Briggs L a., Brown RL. Effect of a disease-specific advance care planning intervention on end-of-life care. J Am Geriatr Soc. 2012;60(5):946-950.

54. Schwartz $\mathrm{CE}$, Wheeler HB, Hammes $\mathrm{B}$, et al. Early intervention in planning end-of-life care with ambulatory geriatric patients: results of a pilot trial. Arch Intern Med. 2002;162(14):1611-1618.

55. Song MK, Kirchhoff KT, Douglas J, Ward S, Hammes B. A randomized, controlled trial to improve advance care planning among patients undergoing cardiac surgery. Med Care. 2005;43(10):10491053.

56. Robinson $\mathrm{C}$ a. Advance care planning: Re-visioning our ethical approach. Can J Nurs Res. 2011;43(2):18-37.

57. Robinson CA. "Our best hope is a cure." Hope in the context of advance care planning. Palliat Support Care. 2012;10(2):75-82. 
58. Niranjan SJ, Huang CHS, Dionne-Odom JN, et al. Lay Patient Navigators' Perspectives of Barriers, Facilitators and Training Needs in Initiating Advance Care Planning Conversations With Older Patients With Cancer. J Palliat Care. 2018;XX(X):1-9.

59. Rocque GB, Dionne-Odom JN, Sylvia Huang $\mathrm{CH}$, et al. Implementation and Impact of Patient Lay Navigator-Led Advance Care Planning Conversations. J Pain Symptom Manage. 2017;53(4):682-692.

60. Hammes BJ, Rooney BL, Gundrum JD. A Comparative, Retrospective, Observational Study of the Prevalence, Availability, and Specificity of Advance Care Plans in a County that Implemented an Advance Care Planning Microsystem. J Am Geriatr Soc. 2010;58(7):1249-1255.

61. Pecanac KE, Repenshek MF, Tennenbaum D, Hammes BJ. Respecting Choices and advance directives in a diverse community. J Palliat Med. 2014;17(3):282-287.

62. Hickman SE, Unroe KT, Ersek MT, Buente B, Nazir A, Sachs GA. An Interim Analysis of an Advance Care Planning Intervention in the Nursing Home Setting. J Am Geriatr Soc. 2016;64(11):2385-2392.

63. O'Connor NR, Moyer ME, Kirkpatrick JN. Scripted Nurse Visits: A Resource-Efficient Palliative Care Model for Ventricular Assist Devices. J Palliat Med. 2016;19(12):1312-1315.

64. Lakin JR, Koritsanszky LA, Cunningham R, et al. A Systematic Intervention To Improve Serious Illness Communication In Primary Care. Health Aff (Millwood). 2017;36(7):1258-1264.

65. Metzger M, Song M-K, Ward S, Chang PP-Y, Hanson LC, Lin F-C. A randomized controlled pilot trial to improve advance care planning for LVAD patients and their surrogates. Heart Lung. 2016;45(3):186-192.

66. Metzger M, Song MK, Devane-Johnson S. LVAD patients' and surrogates' perspectives on SPIRITHF: An advance care planning discussion. Hear Lung. 2016;45(4):305-310.

67. Song M-K, Ward SE, Happ MB, et al. Randomized controlled trial of SPIRT: An effective approach to preparing African American dialysis patients and families for end of life. Res Nurs Health. 2009;32(3):260-273.

68. Song MK, Ward SE, Fine JP, et al. Advance Care Planning and End-of-Life Decision Making in Dialysis: A Randomized Controlled Trial Targeting Patients and Their Surrogates. Am J Kidney Dis. 2015;66(5):813-822.

69. Song MK, Metzger M, Ward SE. Process and impact of an advance care planning intervention evaluated by bereaved surrogate decision-makers of dialysis patients. Palliat Med. 2017;31(3):267274.

70. Stein RA, Sharpe L, Bell ML, Boyle FM, Dunn SM, Clarke SJ. Randomized Controlled Trial of a Structured Intervention to Facilitate End-of-Life Decision Making in Patients With Advanced Cancer. J Clin Oncol. 2013;31(27):3403-3410. 
71. Stanford J, Sandberg DM, Gwyther L, Harding R. Conversations Worth Having: The Perceived Relevance of Advance Care Planning among Teachers, Hospice Staff, and Pastors in Knysna, South Africa. J Palliat Med. 2013;16(7):762-767.

72. Huang $\mathrm{C}-\mathrm{HS}$, Crowther $\mathrm{M}$, Allen RS, et al. A pilot feasibility intervention to increase advance care planning among African Americans in the deep south. J Palliat Med. 2016;19(2):164-173.

73. Karel MJ, Powell J, Cantor MD. Using a Values Discussion Guide to facilitate communication in advance care planning. Patient Educ Couns. 2004;55(1):22-31.

74. Smith SL. Advance Care Planning Communication for Young Adults: A Role for Simulated Learning. J Hosp Palliat Nurs. 2017;19(5):460-467.

75. Kazmerski T, Weiner D, Schachner D, Matisko J, Maurer S. Advance Care Planning in Pediatric Cf Patients: A Quality Improvement Project. Pediatr Pulmonol. 2015;50:446.

76. Song MK, Ward SE, Lin FC, et al. Racial Differences in Outcomes of an Advance Care Planning Intervention for Dialysis Patients and Their Surrogates. J Palliat Med. 2016;19(2):134-142.

77. Davison SN. Advance Care Planning in Patients With Chronic Kidney Disease. Semin Dial. 2012;25(6):657-663.

78. Davison SN, Torgunrud C. The Creation of an Advance Care Planning Process for Patients With ESRD. Am J Kidney Dis. 2007;49(1):27-36.

79. Mahon MM. An Advance Directive in Two Questions. J Pain Symptom Manage. 2011;41(4):801-807.

80. Pearce J, Ridley J. Communication in life-limiting illness: A practical guide for physicians. B C Med J. 2016;58(5):262-267.

81. Dallas RH, Wilkins ML, Wang J, Garcia A, Lyon ME. Longitudinal Pediatric Palliative Care: Quality of Life \& Spiritual Struggle (FACE): Design and methods. Contemp Clin Trials. 2012;33(5):1033-1043.

82. Kimmel AL, Wang J, Scott RK, Briggs L, Lyon ME. FAmily CEntered (FACE) advance care planning: Study design and methods for a patient-centered communication and decision-making intervention for patients with HIV/AIDS and their surrogate decision-makers. Contemp Clin Trials. 2015;43:172-178.

83. Curtin $\mathrm{KB}$, Watson $\mathrm{AE}$, Wang J, Okonkwo OC, Lyon ME. Pediatric advance care planning (pACP) for teens with cancer and their families: Design of a dyadic, longitudinal RCCT. Contemp Clin Trials. 2017;62(May):121-129.

84. Piamjariyakul U, Myers S, Werkowitch M, Smith CE. End-of-life preferences and presence of advance directives among ethnic populations with severe chronic cardiovascular illnesses. Eur J Cardiovasc Nurs. 2014;13(2):185-189.

85. Norlander L, McSteen K. The Kitchen Table Discussion: a creative way to discuss end-of-life issues. Home Healthc Nurse. 2000;18(8):532-540. 
86. Briggs L. Shifting the Focus of Advance Care Planning: Using an In-depth Interview to Build and Strengthen Relationships. J Palliat Med. 2004;7(2):341-349.

87. Korfage $\mathrm{I}$, Rietjens JAC, Overbeek $\mathrm{A}$, et al. A cluster randomized controlled trial on the effects and costs of advance care planning in elderly care: study protocol. BMC Geriatr. 2015;15.

88. Rietjens JA, Korfage $\mathrm{I}$, Dunleavy $\mathrm{L}$, et al. Advance care planning--a multi-centre cluster randomised clinical trial: the research protocol of the ACTION study. BMC Cancer. 2016;16:264.

89. Malhotra C, Sim DKL, Jaufeerally F, et al. Impact of advance care planning on the care of patients with heart failure: study protocol for a randomized controlled trial. Trials. 2016;17.

90. der Schmitten J, Rotharmel S, Mellert C, et al. A complex regional intervention to implement advance care planning in one town's nursing homes: Protocol of a controlled inter-regional study. BMC Health Serv Res. 2011;11:14.

91. Bernacki R, Hutchings M, Vick J, et al. Development of the Serious Illness Care Program: a randomised controlled trial of a palliative care communication intervention. BMJ Open. 2015;5(10):e009032.

92. Song MK, Ward SE. Making Visible a Theory-Guided Advance Care Planning Intervention. J Nurs Scholarsh. 2015;47(5):389-396.

93. Song MK, Unruh ML, Manatunga A, et al. SPIRIT trial: A phase III pragmatic trial of an advance care planning intervention in ESRD. Contemp Clin Trials. 2018;64(July 2017):188-194.

94. Prommer EE. Using the values-based history to fine-tune advance care planning for oncology patients. J Cancer Educ. 2010;25(1):66-69.

95. Zadeh S, Pao M, Wiener L. Opening end-of-life discussions: how to introduce Voicing My CHOiCES $^{\mathrm{TM}}$, an advance care planning guide for adolescents and young adults. Palliat Support Care. 2015;13(3):591-599.

96. Balaban RB. A physician's guide to talking about end-of-life care. J Gen Intern Med. 2000;15(3):195200.

97. Donovan HS, Ward SE, Song MK, Heidrich SM, Gunnarsdottir S, Phillips CM. An update on the representational approach to patient education. J Nurs Scholarsh. 2007;39(3):259-265.

98. Lewin S, Hendry M, Chandler J, et al. Assessing the complexity of interventions within systematic reviews : development, content and use of a new tool ( iCAT_SR ). 2017:1-13.

99. Hoffmann TC, Oxman AD, Ioannidis JPA, et al. Enhancing the usability of systematic reviews by improving the consideration and description of interventions. BMJ.2017:1-8.

100. Sudore RL, Lum HD, You JJ, et al. Defining Advance Care Planning for Adults: A Consensus Definition From a Multidisciplinary Delphi Panel. J Pain Symptom Manage. 2017;53(5):821-832.e1. 
101. Tulsky JA, Beach MC, Butow PN, et al. A Research Agenda for Communication Between Health Care Professionals and Patients Living With Serious Illness. JAMA Intern Med. 2017;177(9):1361-1366.

102. Scherrens A-L, Beernaert $\mathrm{K}$, Robijn $\mathrm{L}$, et al. The use of behavioural theories in end-of-life care research: A systematic review. Palliat Med. 2018:26921631875821.

103. Sudore RL, Knight SJ, McMahan RD, et al. A novel website to prepare diverse older adults for decision making and advance care planning: A pilot study. $J$ Pain Symptom Manage. 2014;47(4):674-686.

104. Masters S, Gordon J, Whitehead C, Davies O, Giles LC, Ratcliffe J. Coaching older adults and carers to have their preferences heard $(\mathrm{COACH})$ : A randomised controlled trial in an intermediate care setting (study protocol). Australas Med J. 2012;5(8):444-454.

105. Green MJ, Levi BH. Development of an interactive computer program for advance care planning. Heal Expect. 2009;12(1):60-69.

\section{Appendices}

\section{Additional tables Systematic Review}

Table A1. Adapted tool quality assessment observational studies

Table A2. Risk of Bias Assessment Trials

Table A3. Risk of Bias Assessment Observational studies

Table A4. Risk of bias Assessment Mixed-method studies, quantitative part

Table A5. Assessment of quality of reporting Mixed-method studies, qualitative part

Table A6. Assessment of quality of reporting, Qualitative studies

Table A7. Evidence from qualitative studies 


\title{
Chapter 3
}

Anticipating the future in pediatric palliative care; a qualitative study into the perspectives of parents and healthcare professionals

\author{
Lisa M. Verberne \\ Jurrianne C. Fahner \\ Stephanie F.V. Sondaal \\ Antoinette Y.N. Schouten - van Meeteren \\ Chris C. de Kruiff \\ Johannes J.M. van Delden \\ Marijke C. Kars
}

Submitted 


\section{Abstract}

Objective: To explore how parents and healthcare professionals anticipate the future in pediatric palliative care.

Study Design: A qualitative interview study using thematic analysis was performed. Single and repeated semi-structured interviews were undertaken with parents $(n=42)$ and healthcare professionals $(n=35)$ of 24 children, receiving palliative care.

Results: Initiatives to share future perspectives were aimed at ensuring the child's quality of life and comfort, also during the end of life. Anticipating the future was seen in three forms: goal-directed conversations, anticipated care and guidance on the job. Goal-directed conversations were initiated by either parents or healthcare professionals to ensure others could align with their point of view regarding future care and treatment. Anticipated care meant healthcare professionals or parents organized practical care arrangements for future scenarios with or without informing each other. Guidance on the job, was a form of short-term anticipation, whereby healthcare professionals guide parents ad hoc through difficult situations.

Conclusions: Anticipating the future in pediatric palliative care is mainly focused on achievement of individual care goals of both families and healthcare professionals, practical arrangements in advance and short term anticipation when a child deteriorates. A more open approach early in disease trajectories exploring perspectives on the future could allow parents to anticipate more gradually and to integrate their values and preferences into the care and treatment of their child. 


\section{Introduction}

In the Netherlands, 4000 to 6700 children with life-limiting conditions can be considered for pediatric palliative care (PPC). ${ }^{1}$ Annually, 1000 of these children die, of whom $30-79 \%$ die at home with their parents as primary care givers. ${ }^{2-4}$ This number is increasing as current medical treatment options allow critically ill children to live longer, ${ }^{1,5,6}$ being dependent on high-complex care for a longer period of time and expanding care facilities at home. ${ }^{7}$ During different disease trajectories, preparing for future scenarios is perceived as complex and challenging by both families and healthcare professionals (HCPs). ${ }^{8-11}$ For parents, facing the future is emotionally challenging as it confronts them with the possible loss of their child. ${ }^{11,12}$ By discussing the future with families, HCPs fear to take away hope and disturb the families' way of coping with the serious illness of their child. ${ }^{9,10}$ These factors may result in refraining from facing the future leading to a delayed initiation of PPC and insufficient attention to the child's quality of life (QoL), especially at the end-of-life. ${ }^{13}$ However, growing evidence shows that both families and HCPs value strategies to explore future scenarios in advance. ${ }^{12,14-17}$ In recent literature, there is growing interest in the concept of advance care planning (ACP) as a strategy to identify goals and preferences for future care and treatment, to share these thoughts between families and HCPs and document any preferences if considered appropriate. ${ }^{18}$ Yet, it is known that ACP in pediatrics occurs infrequently and often too late due to barriers on the level of families, HCPs and healthcare organizations. ${ }^{8-10,15}$ Limited research is done on current strategies of facing the future as used by HCPs and families when caring for a seriously ill child. We hypothesize that different ways of anticipating the future may occur. Insight in current approaches of anticipating the future in PPC is needed. Based on these insights, strategies can be further developed to elicit individual family's values and preferences for future care and treatment in order to support high quality family-centered care from diagnosis of a life-limiting condition until the end-of-life. Therefore, this study aims to explore how parents and HCPs currently anticipate and discuss future care and treatment in PPC. 


\section{Methods}

\section{Study design}

As part of a larger study exploring the lived experience of families receiving PPC and their HCPs involved, an explorative qualitative study was conducted using inductive thematic analysis to elucidate approaches of anticipating the future among parents and HCPs. The research ethics committee of the Academic Medical Centre Amsterdam approved the study (June 12, 2013; Reference number:W13_120\#13.17.0153). All participants gave written informed consent.

\section{Sample}

Parents of children with a life-limiting condition, receiving care from the pediatric palliative care team (PPCT) of the Emma Children's Hospital, were purposefully selected. Maximum variation was sought with respect to the child's diagnosis, age and disease trajectory, including end-oflife. ${ }^{19-21}$ Parents could also be included after the child's death to achieve insight in very last period of life. PPCT case managers as well as other HCPs most involved in each selected case were also recruited.

\section{Data collection}

Parents were individually interviewed at home and HCPs at their workplace or by telephone between August 2013 and January 2016. Interviews lasted from 30 minutes to 2 hours. They were conducted by independent researchers (LV, MK, MB) from a university hospital other than where the PPCT was established. A topic list based on literature and expert knowledge guided each interview (Appendix; Topic list 1 and 2). The interviewer explored how and to what extend parents and HCPs anticipated the future in PPC and how they experienced this. Audio recordings of the interviews were anonymously transcribed verbatim.

\section{Data analysis}

The data was analyzed using inductive thematic analysis. ${ }^{22-24}$ Validity was ensured by a rigorous study design and repetitive meetings of the research team (LV, JF, SS and MK). An audit trail recording methodological choices and substantive ideas and concepts related to the 
interpretation of the data was used to further ensure validity and provide transparency of the results.

The analysis yielded four steps. First, transcripts of five cases were (re)read to gain an overall understanding of the study objectives in context of the interviews. Meaningful fragments were identified in all five interviews. These fragments were coded in a data-driven manner (LV, SS and MK). ${ }^{22}$ Second, of each interview, a narrative report was made to summarize strategies to approach future care. Fragments, initial codes and summaries were compared and discussed aimed at reaching consensus in interpretation. The initial codes were combined, recoded and adapted towards a code tree with themes and concepts at a more abstract and conceptual level. Third, all interviews were coded using NVivo $10 .{ }^{25}$ After coding each case, the coding tree was evaluated and, if indicated, revisited. Fourth, based on the code tree potential themes were identified. These were consistently verified, reviewed and refined on coherency by constant comparison of the data per theme and of the whole thematic map in relation to all the data. ${ }^{23}$ Saturation was reached at a conceptual level. ${ }^{26}$ The Consolidated Criteria for Reporting Qualitative Research was used to structure the report. ${ }^{27}$

\section{Results}

Of the 35 cases eligible for participation, 24 were included, resulting in the participation of 42 parents (24 mothers and 18 fathers) and 35 HCPs. Reasons for non-participation were parental refusal $(n=5)$ and HPCs considering a case too vulnerable to participate $(n=6)$. Three cases were included after the child's death (parents, $n=6 ; \mathrm{HCPs}, n=10$ ) and in three other cases, a repeated interview with the parents $(n=5)$ and with HCPs $(n=7)$ was done after the child's death. Several HCPs were involved in multiple cases and, thus, interviewed several times. In total, 105 semi-structured interviews were conducted (parents, $n=47 ; \mathrm{HCPs}, n=58$ ). For participant characteristics see Table 1 and 2. 
Table 1. Characteristics of the parents $(n=42)$ and their ill child $(n=24)$

\begin{tabular}{|c|c|c|}
\hline Characteristics & Number $(N)$ & Percentages (\%) \\
\hline $\begin{array}{c}\text { Gender parent } \\
\text { Male } \\
\text { Female }\end{array}$ & $\begin{array}{l}18 \\
24\end{array}$ & $\begin{array}{l}43 \\
57\end{array}$ \\
\hline $\begin{array}{l}\text { Age parent }^{\mathrm{a}} \\
\quad<30 \\
30-40 \\
>40\end{array}$ & $\begin{array}{c}2 \\
29 \\
9\end{array}$ & $\begin{array}{c}5 \\
73 \\
23\end{array}$ \\
\hline $\begin{array}{l}\text { Marital stage } \\
\text { Married/cohabiting } \\
\text { Divorced/not cohabiting }\end{array}$ & $\begin{array}{c}38 \\
4\end{array}$ & $\begin{array}{l}90 \\
10\end{array}$ \\
\hline $\begin{array}{l}\text { Education } \\
\text { Low }^{\mathrm{D}} \\
\text { Middle }^{\mathrm{c}} \\
\text { High }^{\mathrm{a}} \\
\end{array}$ & $\begin{array}{c}5 \\
15 \\
22 \\
\end{array}$ & $\begin{array}{l}12 \\
36 \\
52 \\
\end{array}$ \\
\hline $\begin{array}{l}\text { Age child (at first interview) (years) } \\
0-1 \\
1-5 \\
5-12 \\
12-16 \\
\geq 16\end{array}$ & $\begin{array}{l}1^{\mathrm{e}} \\
13^{\mathrm{T}} \\
7 \\
2 \\
1\end{array}$ & $\begin{array}{c}4^{\mathrm{e}} \\
54^{\top} \\
29 \\
8 \\
4\end{array}$ \\
\hline $\begin{array}{l}\text { Child gender } \\
\text { Male } \\
\text { Female }\end{array}$ & $\begin{array}{l}12 \\
12\end{array}$ & $\begin{array}{l}50 \\
50\end{array}$ \\
\hline $\begin{array}{l}\text { Child diagnosis } \\
\text { Non-malignant disease (total) } \\
\text { Congenital anomalies } \\
\text { Neurodegenerative disease } \\
\text { Metabolic disease } \\
\text { Malignant disease (total) } \\
\text { Central nervous system tumor } \\
\text { Bone/soft tissue sarcoma } \\
\text { Neuroblastoma } \\
\text { Leukemia }\end{array}$ & $\begin{array}{c}15 \\
11 \\
2 \\
2 \\
9 \\
5 \\
2 \\
1 \\
1\end{array}$ & $\begin{array}{c}63 \\
46 \\
8 \\
8 \\
38 \\
21 \\
8 \\
4 \\
4\end{array}$ \\
\hline $\begin{array}{l}\text { Time since diagnosis } \\
\begin{array}{l}0-6 \text { months } \\
6-12 \text { months } \\
1-2 \text { years } \\
2-5 \text { years } \\
>5 \text { years }\end{array}\end{array}$ & $\begin{array}{l}2 \\
3 \\
7 \\
8 \\
4\end{array}$ & $\begin{array}{c}8 \\
13 \\
29 \\
33 \\
17\end{array}$ \\
\hline $\begin{array}{l}\text { Palliative phase at first interview } \\
\text { Diagnostic phase } \\
\text { Phase of loss of normality } \\
\text { Phase of decline } \\
\text { Dying phase }\end{array}$ & $\begin{array}{c}0 \\
15 \\
6 \\
3\end{array}$ & $\begin{array}{c}0 \\
63 \\
25 \\
13\end{array}$ \\
\hline
\end{tabular}

Percentages may not equal 100 due to rounding.

a Age of tw o parents is missing.

b Low : primary school, low er secondary general education, low er vocational education.

${ }^{c}$ Middle: higher secondary general education, intermediate vocational education.

${ }^{\mathrm{d}}$ High: higher vocational education, university.

e In one case, the interview took place after the child's death.

${ }^{f}$ In tw o cases, the interview took place after the child's death. 
Table 2. Characteristics of the healthcare professionals $(\mathrm{HCP})(\mathrm{n}=35)$

\begin{tabular}{|c|c|c|c|}
\hline \multicolumn{2}{|l|}{ Characteristics } & \multirow{2}{*}{$\frac{\text { Number }(\mathbf{N})}{14}$} & \multirow{2}{*}{$\frac{\text { Percentages (\%) }}{40}$} \\
\hline Vocation HCP & Pediatrician $^{a}$ & & \\
\hline & Pediatric revalidation specialist & 1 & 3 \\
\hline & General practitioner & 5 & 14 \\
\hline & Case managers (PPCT nurse) & 6 & 17 \\
\hline & Homecare nurse & 7 & 20 \\
\hline & Other $^{\mathrm{D}}$ & 2 & 6 \\
\hline \multirow{4}{*}{$\begin{array}{l}\text { Years of working } \\
\text { experience in } \\
\text { palliative care? }\end{array}$} & $0-5$ years & 5 & 14 \\
\hline & $6-15$ years & 9 & 26 \\
\hline & $>15$ years & 19 & 54 \\
\hline & Unknown & 2 & 6 \\
\hline
\end{tabular}

Anticipating the future

Many parents and HCPs experienced anticipation of the future as difficult because of uncertainties due to the unpredictability of the disease course. Moreover, it required acknowledgement of disease progression and facing the child's inevitable death. Despite these difficulties, parents as well as HCPs were seen to anticipate future care. Initiatives to share perspective were predominantly aimed at ensuring the child's quality of life and comfort, also during the end-of-life. However, individual perspectives regarding the future were not shared between parents and HCPs to a large extent. Three forms of future anticipation were revealed: goal-directed conversations (GDC), anticipated care (AC) and guidance on the job (GOTJ). For illustrating quotes see Table 3. 


\section{Table 3. Illustrative quotes of goal-directed conversations, anticipated care and}

\section{guidance on the job taken from the interviews}

\begin{tabular}{|c|c|}
\hline \multicolumn{2}{|c|}{ Aspects of goal-directed conversations } \\
\hline \multicolumn{2}{|c|}{ Goals } \\
\hline Parents & $\begin{array}{l}\text { MD, case } 23 \text {, father: For me, he (son) does not have to suffer pain. In the end that is not } \\
\text { what we want. [...] We have indicated to the oncologist that in case something happens } \\
\text { and he has to be resuscitated, that we do not want that because he will not survive it } \\
\text { well. [...] We really chose quality of life. }\end{array}$ \\
\hline HCPs & $\begin{array}{l}\text { MD, case } 20 \text {, pediatrician: I discussed in the beginning, whether she would go to an ICU, } \\
\text { [have] a DNR order. Parents were both very clear about it, which made it easier for me, } \\
\text { no resuscitation and aiming for comfort. }\end{array}$ \\
\hline \multicolumn{2}{|r|}{ Parents' varying strategies to cope with anticipated loss } \\
\hline Parents & $\begin{array}{l}\text { NMD, case } 7 \text {, mother: Now that is he in such an advanced stage of the disease, and } \\
\text { possibly because of my own character, I need to know [what I can expect in the future]. I } \\
\text { don't live in the future, but I need to know, I need to understand. I somehow need to } \\
\text { prepare myself, because for me it is also important to touch [the future] and see how that } \\
\text { feels, because I have the feeling that if I don't do this, I won't survive the blow that is } \\
\text { coming. }\end{array}$ \\
\hline HCPs & $\begin{array}{l}\text { MD, case } 13 \text {, pediatrician: The father's character is one of 'what if, what if'. And the } \\
\text { mother is much more the one who says 'yes, yes', and who gives me the feeling that she } \\
\text { sometimes would rather not talk about it. They are two different people in this respect. It } \\
\text { happens that father addresses me separately, he does a literature search [...] and refers } \\
\text { back to parts of the talks we have had before. }\end{array}$ \\
\hline \multirow[t]{2}{*}{$\begin{array}{l}\text { Framing } \\
\text { HCPs }\end{array}$} & MD, case 5, pediatric oncologist (after marking end of curative phase): What I usually try \\
\hline & $\begin{array}{l}\text { to do is a sort of looking ahead. The emphasis will often lie on the first weeks, but [...] we } \\
\text { always [try] to make a sketch of later phases. [...] And later we go into those more } \\
\text { deeply, when they are ready for it, but it is good to know that that phase will come, that } \\
\text { we sometimes already have to take measures for that now. But talking about this also } \\
\text { helps, [...] to already prepare them for it. The next time we meet, I've noticed parents } \\
\text { come back with a lot of questions. And in such a way you color in the drawings more and } \\
\text { more, the closer it gets. }\end{array}$ \\
\hline \multicolumn{2}{|r|}{ Revisiting discussions on future treatment } \\
\hline & $\begin{array}{l}\text { NMD, case } 8, \text { mother: I feel that Pim [son] is doing better than [the doctors] ever } \\
\text { expected. So, then I believe it [decisions] should be adjusted, not regarding not } \\
\text { resuscitating, [...] if the heart would stop, it stops and then you might create more } \\
\text { damage [if you would resuscitate]. But for example, with intense pneumonia, and you } \\
\text { think he just needs help a little longer, then I would like him to be given supportive } \\
\text { respiration. }\end{array}$ \\
\hline \multicolumn{2}{|c|}{ Anticipated Care } \\
\hline \multicolumn{2}{|r|}{ 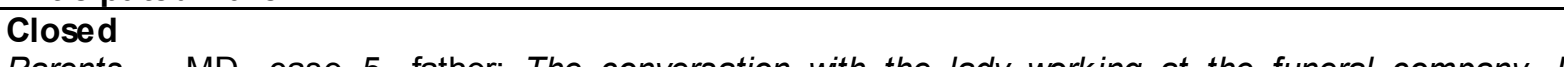 } \\
\hline Parents & $\begin{array}{l}\text { MD, case } 5 \text {, father: The conversation with the lady working at the funeral company, I } \\
\text { initiated it myself because I found it important to start with that on time. So, I looked for } \\
\text { contacts in the neighborhood and it [meeting] was organized in a flash. And she [funeral } \\
\text { organizer] found it very valuable, despite that it was a very unclear trajectory, [...because] } \\
\text { they could think ahead already now, or Pieter [son] can indicate for himself what he likes. }\end{array}$ \\
\hline HCPs & $\begin{array}{l}\text { NMD, case 18, PPCT nurse: At some point, he [child] will be able to do so little that he will } \\
\text { give up. [...] And I think that when certain things are no longer possible at some point, he } \\
\text { will quit. I hope that that will still take some time, but it is not for him to get into a } \\
\text { vegetative state [...] My goal with him is, maybe a bit weird, [but] prepare him for death. I } \\
\text { would want and [organize] someone [to] get into contact with him about the nearing end } \\
\text { and the process of losing all that he could do. }\end{array}$ \\
\hline
\end{tabular}




\begin{abstract}
Open
Parents NMD, case 21, mother: During the last admission, [...] I said then [that] I just do not dare take her home before I learn how to do deeper suction and how to resuscitate. Because when something happens to her [daughter], I want to be able to do something. [...] That was a difficult topic, because the pediatrician was thinking [...] how am I sending a parent home, with so many worries. But what is sometimes not understood is that you would send a parent home with even more worries when they are not able to resuscitate.

HCPs NMD, case 12, pediatrician: Then we thought with the PPCT, what if he has pain, what if he becomes dyspneic, what if he gets a seizure, how will we treat that medically, who will we involve with the care for this patient. [...] Then we wrote a palliative protocol together and [...] visited the two family doctors [...and] made agreements on who would do what. [...] And only when you have that clear, you discuss those steps with parents.

\begin{tabular}{ll}
\hline Guidance on the job \\
\hline Parents & MD, case 22, mother (about the further deterioration of her child): I find it comforting that \\
those thoughts occur in steps and that the emotions also surface in steps. You are being \\
taken by the hand [by the specialized nurse of the PPCT] a bit to look at the situation \\
more from a meta level and to think about and make decisions together, for things that \\
will come but not just yet. [...] I think that that is good because [...] now you can do it in a \\
well thought-out manner. \\
MD, case 5, homecare nurse (when child becomes increasingly dyspneic): He [child] of \\
course did not want anything, he preferred to wait [what would come]. Then I discussed, \\
yCPs [child] are now so uncomfortable, this is not pleasant'. And the parents also said: this \\
is also not what we want. [...] We have discussed it, there are many possibilities to make \\
you [child] calmer. So, I am very open and discuss why I want to do it [start with \\
morphine]. But I have also said that he will not die from the morphine plaster. [...] Then \\
we gave him extra medication because he [child] was very uncomfortable and told them \\
that we would start the pump tomorrow and possibly tonight if things do not improve.
\end{tabular}
\end{abstract}

Goal-directed conversations

Initial conversations, both initiated by HCPs or parents, on future care as a way of sharing each other's perspectives appeared not to occur naturally. Rather, these conversations regarding future scenarios had a conscious and goal-directed intention. In order to align the perspective on future care and treatment, both HCPs and parents shared their views on care and treatment in the future to the other party in the conversation. Initiation of such a conversation and mutual alignment of these care goals proved essential to influence the other party's willingness to adapt their perspective and actions.

HCPs

Usually HCPs took the initiative to start a conversation regarding future care or treatment. HCPs mentioned to initiate a conversation about future care and treatment driven by ethical reasons, such as to prevent medically futile treatments or to ask consent for advance directives. They mentioned practical conversation goals as well, such as to have clarity about the preferred place 
of death. Although HCPs mentioned to explore the parents' perspective in the conversation, they reported to have clear ideas about future care and treatment in advance. These care goals from the HCP's perspective were mostly based on their own perspectives or on discussions within the medical team.

Besides their aim for getting parental consent on future care options, HCPs mentioned talking about the future was also aimed at preparing parents for difficult decision making to be expected in the future. Some HCPs mentioned to initiate a conversation about the future, when they felt the parent had an unrealistic and too positive view on their child's condition.

HCPs used two strategies in goal-directed conversations in order to create a shared perspective on the child's condition. The first strategy was 'marking'. This strategy was used to clearly indicate that the child had entered a new stage in the disease trajectory. This required from parents to reconsider their views on future care. HCPs either marked actual situations in the moment or prepared parents to expect marking moments in the future. Examples were a shift from disease-directed treatment towards symptom-directed treatment or a hospital admission due to deterioration of the child, indicating the child's increased vulnerability. The second strategy was 'framing'. This strategy entailed discussing the child's condition in relation to different disease trajectories and possible options for care and treatment, in order to clarify consequences for the child. For example, this entailed framing the high likelihood of a pediatric intensive care unit admission when continuing treatment or the negative consequences of resuscitating children given their condition.

Parents

Parents took the initiative to start a conversation about the future in order to achieve a good life for their child with the least amount of suffering as possible. Another reason to discuss their future with HCPs could be parental goals of continuing regular family life and to receive clues around the prognosis of their child based on the HCPs' expertise. Parents needed the knowledge and insights of the HCP to be able to arrange the care for their child for a longer period of time and to be able to develop their perspectives on family planning. Parents also needed the HCP's formal approval to get access to care arrangements, such as modifications to 
their homes. Above mentioned goals were mainly reported by parents with a focus on prolonging the child's life as well as by parents with a perceived longer life expectancy of their child.

Those parents who had a focus on comfort care without striving for prolonging life, initiated conversations about their child's future to be able to cope with their own ongoing loss. Some parents reported to start a conversation about future care in order to prevent their child's suffering and unnecessary prolongation of life. These parents sought HCPs' expertise, guidance and agreement on limitation of life-sustaining treatments and options to allow a natural death. Parents who perceived their HCP as easily approachable, felt more openness to ask questions about delicate issues, such as when to stop tube feeding and what could occur during the dying phase of the child. Some parents reported that HCPs had not been open for exploring the future or answering their questions, mainly by referring to prognostic uncertainty.

Few parents reported to initiate a conversation about the future aimed at reconsidering prior treatment limitations written down in an advance directive. These parents had observed a clear, yet unexpected improvement in the child's condition, which in their opinion justified revisiting treatment limitations. Some parents used the strategy of 'framing' similar to HCPs, especially when they feared difficulties at the HCPs side to align to the parents' perspective. Parents felt a need to place the child's condition in relation to a broader context of disease course and treatment options in order to convince HCPs to align to their perspective and goal setting as a parent with expertise on their child's condition.

Overall, the parents' way of coping with the future loss of their child influenced their ability to discuss future care and treatment. Parents, who tend to focus on the 'here-and-now' to be able to cope with feelings of loss and the daily burden of care, experienced difficulties or refused to discussed future care and treatment with HCPs.

\section{Anticipated care}

AC involved being prepared for future scenarios by shaping and organizing care arrangements in advance, in response to anticipated future needs of the child or family. AC was mostly 
initiated by HCPs and sometimes by parents. It either had a 'closed' or 'open' character depending on whether HCPs or parents informed each other about the care arrangements made. Disclosure of 'closed' AC occurred when a need arose among either HCPs or parents to inform each other about the preparations.

HCPs

AC was mainly conducted by HCPs experienced in PPC, such as PPCT members or pediatric homecare nurses, and often discussed amongst HCPs preparing for future care without informing the parents at the time. Examples included ordering medications and equipment for the home setting, creating a contact plan for parents, and involving other important HCPs, such as the PPCT, general practitioner, psychologist or child-life specialist. HCPs often started with 'closed' AC, mainly to prevent unnecessary burden to the parents or to prevent disruption of the parental coping strategy. Disclosure of 'closed' AC occurred when parents were perceived as ready for the intended care arrangements or when the HCPs perceived the child's or the parents' interest as threatened when withholding the planned care. The tuning and timing when to provide insight in 'closed' AC arrangements was experienced as a delicate task, preventing that care would be provided too late or started too early.

Parents

Only a few parents seemed to prepare for the future by organizing care arrangements in advance. Parents also used 'closed' or 'open' AC. Parents only informed HCPs when HCPs invited them to do so or when parents needed help from HCPs to arrange the care they aimed for. An example of 'closed' AC performed by parents is organizing their child's funeral in advance without mentioning this to their HCP. An illustration of 'open' AC was a mother requesting a resuscitation course from the pediatrician to become able to take care of her daughter at home during an emergency.

\section{Guidance on the job}

GOTJ was discerned as a form of short-term anticipation on scenarios or symptoms to be expected in the near future. This form of anticipating the future was only conducted by HCPs. 
GOTJ entailed guiding parents through situations they felt not prepared for but had to face in the nearby future due to the course of the child's disease. HCPs guided parents by explicitly framing the child's current situation and short-term expectations thereof, indicating the necessity why certain actions or approaches were required. In addition, they guided parents by informing them on how to act in the expected situation.

Most examples of GOTJ were related to moments of acute deterioration of the child or situations where death was imminent. HCPs used GOTJ to help parents to provide care aligned to the child's altered needs. It was done in situations where parents seemed to be at risk to overlook new care needs of the child or felt unable to adequately respond to them. This could either be a result of inexperience or of difficulties in coping with the child's end-of-life. This included for example being afraid to hasten the child's death by starting morphine of withdrawal of feeding. GOTJ was both child-focused, aimed at improving the child's comfort, as well as parent-focused, aimed at coaching and supporting parents to 'be there' for their child and to act in the best interest of their child in situations that were difficult to predict or hardly bearable.

Parents indicated appreciation of GOTJ. It made them feel supported and helped them to cope with uncertain future scenarios. It prepared and enabled them to go through difficult steps in the disease trajectory of their child. Some parents felt relieved that HCPs took the lead to proceed in the end-of-life process, not wanting the final responsibility for decisions regarding the child's end-of-life, such as treatment limitations, start of palliative sedation or to end feeding.

\section{Discussion}

Parents and HCPs faced the future to various extends when caring for a child receiving palliative care. Parents and HCPs anticipated the future in order to safeguard the child's quality of life, comfort and quality of death, and to maintain family balance. Three forms of anticipating the future were identified: goal-directed conversations, anticipated care and guidance on the job. The parents' coping with the anticipated loss of their child and the expertise of HCPs to support parents in facing the future largely influenced the occurrence of goal-directed conversations and the need for anticipated care and guidance on the job. 
Many cases in this study showed moments where thoughts about future care and treatment were shared to some extent. However, this study also showed that currently parents and HCPs shared future perspectives mainly when they considered it necessary to safeguard care goals or because the involvement of the other was indispensable. Consequently, these moments of sharing future perspectives rather had a directional than an open, explorative character. Given the current family-centered ideal of providing $\mathrm{PPC}^{28,29}$, anticipating the future might need strategies to explore families' values and preferences for future care, in addition to a goaldirected approach as conducted currently by HCPs in conversations. ${ }^{15,18}$

All parents, even parents who coped with distress by living day-by-day in the present, regularly had thoughts about their child's anticipated early death. This knowledge should stimulate HCPs to explore these perspectives and open up a conversation about what is important to families facing the child's possible death. An open and explorative approach could facilitate shared decision-making and allow for an earlier and more gradual integration of conversations about future care and treatment, as is aimed for in ACP. It is known that parents value ACP, yet they might hesitate to share their values and preferences for their child's care and treatment by themselves. ${ }^{11,30,31}$ As such, it might be helpful when ACP tools support HCPs and parents to find ways to achieve an open and explorative approach when anticipating the future in conversations.

Besides GDC, we also identified AC and GOTJ as forms to anticipate future care and treatment. Although AC was based on the HCPs' or parents' own perspective mainly, values, goals and preferences, as shared in discussions about the future, could inform AC more adequately and align to the families' needs. GOTJ could consecutively build on earlier discussions as well and benefit from well-organized AC. In cases with little or no GDC or AC, occurrence of GOTJ was more prominent and required HCPs to keep track of the child's situation more actively to identify any changes in time. If GOTJ was not performed actively, adequate childcare could be addressed too late, again emphasizing the importance of timely initiation of ACP. ${ }^{30,31}$ Moreover, GDC, AC and GOTJ ideally co-exist and will be used aligned to prior discussions and to the 
child's and family's actual needs. As such, PPC becomes tailored to the individual needs of families.

A barrier to anticipating the future for both parents and HCPs, also found in previous studies, is uncertainty due to the unpredictable course of the disease. ${ }^{8,10,11,20}$ However, predicted survival time is often known to be unreliable ${ }^{32}$ and many parents lag behind in accepting the reality of their child's impending death compared to HCPs. ${ }^{20,33,34}$ As such, Kimbell et al. ${ }^{30}$ argue that uncertainty should not be a barrier but a trigger for conversations about future care, because these conversations could otherwise be addressed too late. Timely initiation of these conversations would allow parents a well-timed transition from an attitude of preserving their child at all costs towards letting go when time has come. ${ }^{31}$

Kimbell et al. and other studies ${ }^{10,30}$ also highlighted the importance of a continuing process in $A C P$, with regular reviewing preferences and goals of care. In this study, parents initiated revisions of previously made agreements, such as advance directives, when they saw their child's condition improved. HCPs regularly discussed the child's current state with parents but whether they monitored changes in parents' perspectives on future care and treatment was less clear. Research for future ACP interventions can investigate how to incorporate regular monitoring and, if needed, revisions of preferences for care and treatment.

This study had some strengths and limitations. Being a one-center study, the generalizability of our results might be limited. Nevertheless purposeful sampling facilitated a wide variation regarding diagnosis, age and phase of palliative trajectory. In addition, this research offers a broad and diverse perspective on data from 24 cases crossing different age groups and including insights of both parents and HCPs. Some HCPs regarded few eligible parents to be too burdened to participate, preventing or delaying their inclusion. This is known as gatekeeping and often seen in palliative care research. ${ }^{35}$ This aspect might have resulted in an overestimation of the occurrence of GDC, AC and GOTJ and an underestimation of parents who have difficulties to anticipate future care. We did not capture differences in cultural and religious aspects, which is a limitation because there are cultural differences in decision-making and communication styles. ${ }^{36}$ Our findings might be limited by not analyzing recordings of the actual conversations 
between parents and $\mathrm{HCPs}$, however the interviews were believed to give valuable insights into perspectives regarding anticipation of the future. Future research could focus on the implementation of ACP to anticipate the future in a more comprehensive way, while exploring values and preferences for future care and treatment without any need for achieving goals, decision-making or arranging care at that moment. Perspectives shared in ACP can function as a foundation for the content of GDC, AC and GOTJ, which might remain necessary in certain situations, even when adequate ACP occurred in advance.

\section{Conclusion}

This study showed that parents and HCPs anticipate the future in PPC mainly by goal-directed conversations, anticipated care and guidance on the job. Sharing of future perspectives often occurred with the intention to achieve a self-defined individual goal in the care for the child, by either the HCP or the parent. The extent of sharing future perspectives was influenced by the parents' ability to cope with anticipated loss and the HCPs' perception thereof. In addition to a goal-directed approach, a more open approach exploring mutual perspectives on future care and treatment could improve timely anticipation of future care needs of the child and family and allow parents to anticipate the future more gradually. 


\section{References}

1. Commissie Bekostiging Intensieve Kind Zorg. Rapport Bekostiging Intensieve Zorg (Dutch Publication); 2010.

2. Molenkamp C, Abu-Saad H, Hamers J. Paediatric Palliative Care in the Netherlands (Dutch Publication). Maastricht: Maastricht University; 2012.

3. Pousset G, Bilsen J, Cohen J, et al. Deaths of children occurring at home in six European countries. Child Care Health Dev. 2009;36(3):375-384.

4. Jagt-van Kampen CT, Van de Wetering MD, Schouten-van Meeteren AYN. The timing, duration, and management of symptoms of children with an incurable brain tumor: A retrospective study of the palliative phase. Neuro-Oncology Pract. 2015;2(2):70-77.

5. IOM. Dying in America: Improving Quality and Honoring Individual Preferences Near the End of Life. Washington, DC: National Academies Press; 2015.

6. Mellor C, Heckford E, Frost J. Developments in paediatric palliative care. Paediatr Child Health (Oxford). 2012;22(3):115-120.

7. Feudtner $\mathrm{C}$, Kang TI, Hexem KR, et al. Pediatric palliative care patients: a prospective multicenter cohort study. Pediatrics. 2011;127(6):1094-1101.

8. Durall A, Zurakowski D, Wolfe J. Barriers to Conducting Advance Care Discussions for Children With Life-Threatening Conditions. Pediatrics. 2012;129(4):e975-e982.

9. Sanderson A, Hall AM, Wolfe J. Advance Care Discussions: Pediatric Clinician Preparedness and Practices. J Pain Symptom Manage. 2016;51(3):520-528.

10. Lotz JD, Jox RJ, Borasio GD, Führer M. Pediatric advance care planning from the perspective of health care professionals: a qualitative interview study. Palliat Med. 2015;29(3):212-222.

11. Lotz JD, Daxer M, Jox RJ, Borasio GD, Führer M. Hope for the best, prepare for the worst: A qualitative interview study on parents' needs and fears in pediatric advance care planning. Palliat Med. 2017;31(8):764-771.

12. Fahner JC, Thölking TW, Rietjens JAC, van der Heide A, van Delden JJM, Kars MC. Towards advance care planning in pediatrics: a qualitative study on envisioning the future as parents of a seriously ill child. Eur J Pediatr. 2020.

13. Davies B, Sehring SA, Partridge JC, et al. Barriers to palliative care for children: perceptions of pediatric health care providers. Pediatrics. 2008;121(2):282-288.

14. DeCourcey DD, Silverman M, Oladunjoye A, Wolfe J. Advance Care Planning and Parent-Reported End-of-Life Outcomes in Children, Adolescents, and Young Adults With Complex Chronic Conditions. Crit Care Med. 2019;47(1):101-108.

15. Fahner JC, Beunders AJM, van der Heide A, et al. Interventions Guiding Advance Care Planning Conversations: A Systematic Review. J Am Med Dir Assoc. 2019;20(3):227-248. 
16. Hein K, Knochel K, Zaimovic V, et al. Identifying key elements for paediatric advance care planning with parents, healthcare providers and stakeholders: A qualitative study. Palliat Med.

2020;34(3):300-308.

17. Orkin J, Beaune L, Moore C, et al. Toward an understanding of advance care planning in children with medical complexity. Pediatrics. 2020;145(3).

18. Rietjens JAC, Sudore RL, Connolly $\mathrm{M}$, et al. Definition and recommendations for advance care planning: an international consensus supported by the European Association for Palliative Care. Lancet Oncol. 2017;18(9):e543-e551.

19. Verberne LM, Kars MC, Schouten-van Meeteren AYN, et al. Aims and tasks in parental caregiving for children receiving palliative care at home: a qualitative study. Eur J Pediatr. 2017;176(3):343354.

20. Kars MC, Grypdonck MHF, van Delden JJM. Being a Parent of a Child With Cancer Throughout the End-of-Life Course. Oncol Nurs Forum. 2011;38(4):E260-E271.

21. Wood F, Simpson S, Barnes E, Hain R. Disease trajectories and ACT/RCPCH categories in paediatric palliative care. Palliat Med. 2010;24(8):796-806.

22. Braun V, Clarke V. Using thematic analysis in psychology. Qual Res Psychol. 2006;3(May 2015):77101.

23. Dierckx de Casterle B, Gastmans C, Bryon E, Denier Y. QUAGOL: A guide for qualitative data analysis. Int J Nurs Stud. 2012;49(3):360-371.

24. Thomas DR. Method Notes A General Inductive Approach for Analyzing Qualitative Evaluation Data. Am J Eval. 2006;27(2):237-246.

25. NVivo qualitative data analysis Software. [Computer Program].Version 10. 2010.

26. Hennink MM, Kaiser BN, Marconi VC. Code Saturation Versus Meaning Saturation: How Many Interviews Are Enough? Qual Health Res. 2017;27(4):591-608.

27. Tong A, Sainsbury P, Craig J. Consolidated criteria for reporting qualitative research (COREQ): A 32item checklist for interviews and focus groups. Int J Qual Heal Care. 2007.

28. ACT. A Guide to the Development of Children's Palliative Care Services. Third Edit. Bristol, UK; 2009.

29. American Academy of Pediatrics. Palliative Care for Children. Pediatrics. 2000;106(2):351-357.

30. Kimbell B, Murray S a, Macpherson S, Boyd K. Embracing inherent uncertainty in advanced illness. BMJ. 2016;354(613):i3802.

31. Rosenberg AR, Wolfe J, Wiener L, Lyon M, Feudtner C. Ethics, Emotions, and the Skills of Talking About Progressing Disease With Terminally Ill Adolescents: A Review. JAMA Pediatr. 2016:1-8.

32. Glare $P$, Sinclair $C$, Downing $M$, Stone $P$, Maltoni $M$, Vigano A. Predicting survival in patients with advanced disease. Eur J Cancer. 2008;44(8):1146-1156. 
33. Wolfe J, Klar N, Grier HE, et al. Understanding of prognosis among parents of children who died of cancer: Impact on treatment goals and integration of palliative care. J Am Med Assoc. 2000;284(19):2469.

34. Kars MC, Grypdonck MHF, De Korte-Verhoef MC, et al. Parental experience at the end-of-life in children with cancer: "Preservation" and "letting go" in relation to loss. Support Care Cancer. 2011;19:27-35.

35. Kars MC, van Thiel GJMW, van der Graaf R, Moors M, de Graeff A, van Delden JJM. A systematic review of reasons for gatekeeping in palliative care research. Palliat Med. 2016;30(6):533-548.

36. Wiener L, McConnell DG, Latella L, Ludi E. Cultural and religious considerations in pediatric palliative care. Palliat Support Care. 2013;11(01):47-67.

\section{Appendices}

Topic lists Anticipating the future 
Chapter 4

Survey of pediatricians caring for children with life-limiting conditions found that they were involved in advance care planning

Jurrianne C. Fahner

Judith A.C. Rietjens

Agnes van der Heide

Johannes J.M. van Delden

Marijke C. Kars

Acta Paediatr. 2020 May;109(5):1011-1018 


\section{Abstract}

Aim: Advance care planning (ACP) is a strategy to align future care and treatment with preferences of patients and families. This study assesses the experiences of ACP among pediatricians caring for children with life-limiting conditions.

Methods: Pediatricians from five Dutch university hospitals and the national oncology center completed a survey during May to September 2017 which investigated experiences with ACP in their most recent case of a deceased child and with ACP in general.

Results: A total of 207 pediatricians responded (36\%). After exclusion of responses with insufficient data $(n=39), 168$ were analyzed (29\%). These included experiences with an individual case in $86 \%$. ACP themes were discussed with parents in all cases. Topics common to many cases were diagnosis, life expectancy, care goals, the parent's fears, and code status. ACP conversations occurred with children in $23 \%$ of cases. The joy in living was the most frequent topic. The frequency of ACP conversations was insufficient according to $49 \%$ of the respondents. In $60 \%$ it was stated that ACP has to result in a documented code status.

Conclusion: Pediatricians reported having ACP conversations mainly with parents focusing on medical issues. There was limited insight into the child's preferences for care and treatment. 


\section{Introduction}

Medical and technological advances have increased the chances of survival among seriously ill children, resulting in a growing population of children living with life-limiting conditions. ${ }^{1}$ These children and their families receive complex chronic and palliative care. As such, they often need support in communicating with the medical team and in medical decision-making. ${ }^{2}$ Parents feel that adequate medical decision-making, designed to serve the best interest of their child is a central element of their parenting role. ${ }^{3}$ Clinicians in pediatrics need to identify individual parental wishes and needs in order to be able to support parents in caring for their child until the end of life. ${ }^{4}$ Medical associations emphasize the importance of anticipating future care and care decisions for children with life-limiting conditions., ${ }^{5,6}$ In 2017, an international panel of experts in palliative care defined advance care planning (ACP) a supportive strategy to identify, discuss and document preferences and goals for future treatment and care in collaboration with family and healthcare providers. ${ }^{7}$ Although research on pediatric ACP is still in its infancy, growing evidence suggests that healthcare providers and families value the concept of ACP. ${ }^{8,9}$ In adult medicine, a growing body of evidence suggests that ACP improves the quality of end of life care and contributes to preferences-concordant care in various patient populations and countries. ${ }^{10}$ Physicians in adult medicine recognize the importance of $A C P$, but encounter barriers such as a lack of knowledge and the discontinuity of care. ${ }^{11} \mathrm{~A}$ single center pediatric study from the United States showed that pediatricians in intensive care medicine and oncology felt prepared to conduct ACP discussions. They perceived parental factors, such as, unrealistic expectations, understanding of the prognosis, and readiness to have the conversation, as the most significant barriers. ${ }^{12,13}$ It is largely unknown whether these results can be generally applied to European countries, because specific healthcare contexts influence attitudes and medical decision-making. ${ }^{14}$ Besides that, it is unknown whether general pediatricians and other subspecialties have similar experiences and skills. In the Netherlands, the concept of ACP is not well known among pediatricians, although we hypothesized that they integrate elements of ACP in their daily practice. Insight into pediatricians' actual experiences with ACP, or elements of ACP, is essential to inform a systematic development of programs and policies to support further implementation of ACP in pediatrics and to develop strategies to overcome perceived barriers. 
Therefore, we invited university hospital pediatricians, both in general and from all subspecialties, plus those from the Dutch national oncology center, to share their experiences, attitudes and skills regarding ACP. We aimed to identify how pediatricians integrate elements of ACP in their daily practice and how pediatricians envisage the concept of ACP in general.

\section{Methods}

\section{Study population}

From May to September 2017, we performed an observational cross-sectional online survey of pediatricians providing tertiary care for children, under the age of 18 , with a life-limiting or lifethreatening disease. All seven university pediatric care centers in the Netherlands were invited to participate. Two centers refused to participate for reasons unknown. Five participated in the study: the Amalia Children's Hospital, Nijmegen; the Beatrix Children's Hospital, Groningen; the Emma Children's Hospital, Amsterdam; the Sophia Children's Hospital, Rotterdam and the Wilhelmina Children's Hospital, Utrecht. The national oncology center, the Princess Máxima Center for Pediatric Oncology, in Utrecht also took part. All pediatricians, including fellows, in active employment in the centers mentioned above were invited to participate. The Participant

Information Sheet indicated that the study focused on pediatricians who were the primary providers of care of children under 18 years of age with life-limiting or life-threatening diseases. It was up to the participants themselves to decide whether they were eligible for participation or not. Residents in pediatrics were not eligible to participate as they rarely take care of children with life-limiting conditions without the involvement of a supervisor. All procedures performed in this study were in accordance with, the ethical standards of the institutional and national research committees and the Helsinki Declaration and its later amendments. Participants were informed about the study by a separate online page before the survey started. Informed consent was obtained by virtue of completion.

\section{Data collection}

All pediatricians received an invitation by email with a link to the survey via contacts in the centers participating. The survey was conducted using the electronic software NETQ Collector 
Premium, Version: 2015.Q2 (Survalyzer BV, Utrecht, The Netherlands). A reminder email was sent twice at approximate intervals of three weeks to all non-responders.

\section{Survey development}

ACP was defined on the introduction page of the survey, since pediatricians in the Netherlands are not familiar with the concept of ACP in general. ACP was defined for this survey as: 'communication with seriously ill children and their families about the goals and preferences for future medical care and treatment.' We used the theory of planned behavior to identify which determinants might influence experiences and perspectives regarding ACP among pediatricians. ${ }^{15}$ The theory of planned behavior consists of three determinants that influence one's intention to perform certain behavior. These are: perceived behavioral control; attitudes toward the behavior; and subjective norms. In order to address those determinants, we asked respondents how they perceive their own communication skills, relevant in $A C P$, in both their most recent case of a child who subsequently died and in general. In addition questions were asked about what they expect from ACP and what they perceive as subjective norms for the timing, frequency, and content of ACP. The survey was divided into two parts. Part one of the survey

explored the ACP experiences of pediatricians in their most recent case of a child who died. The second part concerned the skills, attitudes, and perspectives regarding ACP in general. The survey consisted of 73 items and was based on an existing questionnaire ${ }^{12,13}$ and items developed from the beginning of the research based on the previous work of the study team.,16 An expert panel of five pediatricians performed pilot surveys which resulted in several linguistic adjustments. (See Appendix for the questionnaire)

\section{Statistical analysis}

Data were analyzed using IBM SPSS Statistics for Windows, Version 25.0 (IBM Corp, Armonk, New York, USA). The descriptive statistics were reported. Data are reported as means with standard deviations or ranges for quantitative variables, and as frequency distributions for categorical data. 


\section{Results}

Of the 572 pediatricians invited to participate, 207 responded (36\%). A total of 39 responses were excluded from further analysis due to incomplete data (< 10/73 items) (19\%). The characteristics of the remaining 168, out of 572 pediatricians, (29\%) are reported in Table 1. A total of $84 \%$ of the participants whose responses were analyzed had practiced for more than ten years. Nearly one-third of these physicians worked in general pediatrics (27\%).

\section{Table 1 Respondent characteristics}

\begin{tabular}{|l|c|}
\hline Characteristics & Respondents \\
\hline $\begin{array}{l}\text { Involved as primary physician until a child's death } \\
(\mathrm{n}=168), \mathrm{n}(\%)\end{array}$ & $145(86)$ \\
Yes & $23(14)$ \\
No & $102(64)$ \\
\hline Gender $(\mathrm{n}=160), \mathrm{n}(\%)$ & $58(36)$ \\
Female & $46.0(+/-8.6)$ \\
Male & $18.3(+/-8.8)$ \\
\hline Mean age $(\mathrm{n}=158)$, years $(\mathrm{SD})$ & \\
\hline Mean working experience $(\mathrm{n}=160)$, years (SD) & $25(16)$ \\
\hline Working experience $(\mathrm{n}=160), \mathrm{n}(\%)$ & $84(53)$ \\
$<10$ years & $51(32)$ \\
10-20 years & \\
>20 years & $43(27)$ \\
& $31(19)$ \\
Subspecialty $(\mathrm{n}=160), \mathrm{n}(\%)$ & $25(16)$ \\
General pediatrics & $19(12)$ \\
Neonatology & $12(8)$ \\
Oncology & $74(46)$ \\
ICU & \\
Neurology & \\
Other & \\
\hline
\end{tabular}

Experiences with a case of a child who died

Among the responses analyzed, 145 pediatricians reported on their most recent case of a child who died after a life-limiting condition (86\%). The case characteristics are presented in Table 2. The majority of cases concerned a child who had died in the past two years (81\%). Cancer (16\%), neurologic disorders (18\%), and conditions originating in the perinatal period (17\%) were the most common diagnoses. The respondents had been involved as the child's primary physician for a mean period of 2.2 years (SD +/-3.8). Some respondents, $(27 \%)$, were involved in all phases of the disease trajectory, from diagnosis to death. In $40 \%$ of the cases, children died 
within their first year of life. In 37\%, children died at an age of 1-12 years, and $23 \%$ died at or older than 12 years of age. A hospital was the place of death in $70 \%$ of the cases. Children were judged by the respondents to be competent during their disease trajectory in $17 \%$ of the cases. These children had a mean age at death of 13.1 years (range 3.9-18.0, SD +/- 4.2). In 42\%, these children were aged under 12 at the time of death. The common reasons for being judged incompetent were their young age (55\%) and developmental disorders (18\%).

\section{Table 2 Case characteristics}

\begin{tabular}{|c|c|}
\hline Characteristics & Children who died \\
\hline Gender ( $n=145), n(\%)$ & \\
\hline Male & $88(61)$ \\
\hline Female & $57(39)$ \\
\hline Year of death $(n=145), n(\%)$ & \\
\hline$<2015$ & $19(13)$ \\
\hline 2015 & $9(6)$ \\
\hline 2016 & $37(26)$ \\
\hline 2017 & $80(55)$ \\
\hline Mean age at death $(n=145)$, years (SD, range) & $6.0(+/-6.2$, range $0.0-18.0)$ \\
\hline Place of death $(n=145), n(\%)$ & \\
\hline Home & $42(29)$ \\
\hline Hospital & $100(69)$ \\
\hline Hospice & $2(1)$ \\
\hline Elsewhere & $1(1)$ \\
\hline Diagnosis $(n=145), n(\%)$ & \\
\hline Neoplasms & $23(16)$ \\
\hline Neurologic disorders & $26(18)$ \\
\hline Congenital anomalies & $14(10)$ \\
\hline Perinatal disorders & $24(17)$ \\
\hline Other & $58(40)$ \\
\hline Competent $(n=145), n(\%)$ & \\
\hline Yes & $24(17)$ \\
\hline No, due to young age & 79 (55) \\
\hline No, due to developmental disorder & $26(18)$ \\
\hline No, due to low consciousness & $12(8)$ \\
\hline No, due to emotional distress & $2(1)$ \\
\hline No, due to other cause & $2(1)$ \\
\hline $\begin{array}{l}\text { Involvement of respondent as primary physician in } \\
\ldots(n=145), N(\%)\end{array}$ & \\
\hline Diagnostic phase & $82(57)$ \\
\hline Stable phase & $79(55)$ \\
\hline Phase of decline & $121(83)$ \\
\hline End of life phase & $118(81)$ \\
\hline $\begin{array}{l}\text { Mean duration of involvement as primary physician } \\
(n=145) \text {, years (SD, range) }\end{array}$ & $2.2(3.8$, range $0.0-17.0)$ \\
\hline
\end{tabular}


An overview of how ACP was addressed in the cases described, is presented in Table 3 . Pediatricians discussed one or more topics related to ACP with parents in all cases. Topics commonly discussed with parents were the child's diagnosis (91\%), life expectancy (90\%), goals of care (87\%), fears and worries (87\%) and code status (86\%). Discussion of ACP themes with children occurred in $23 \%$ of the cases. Of these children, $67 \%$ were judged to be-competent. The children who were not judged as competent, but were still involved in the conversations had a mean age of 8.9 years (range 2.2-12.2) at death. With two competent children, none of the topics, previously listed, were discussed. Common topics discussed with children were: their joy of life (19\%); their diagnosis (17\%); their fears and worries (17\%); the goals of care (15\%); and their hopes (15\%). Location of death (5\%) and code status (5\%) were the least reported as being discussed with the children.

Pediatricians reported that in $92 \%$ of the cases, some goals and preferences for future medical treatment and care had been documented in the medical record. An absence of any documentation of goals and preferences for future medical treatment and care in the medical record was reported in $8 \%$. Discussions about whom to identify as the legal representative of the child occurred in $52 \%$. In $41 \%$ of all cases the legal representative was documented in the medical record, being both parents in $77 \%$, and the mother alone in $18 \%$ of those cases.

The care provided was perceived as in line with the parent's preferences in $86 \%$ of the cases reported. In 5\%, the respondents reported it was unclear to them if the care provided was in line with the parent's preferences. Pediatricians reported that in $25 \%$ of cases, they perceived the care provided as in line with the child's preferences. In 74\%, they reported the degree of agreement was unclear to them. The care provided was reported as in line with prior ACP conversations in 92\%. The pediatricians reported being satisfied with their own role in communicating in $95 \%$ of the cases reported. 
Table 3 Elements of ACP in the reported cases

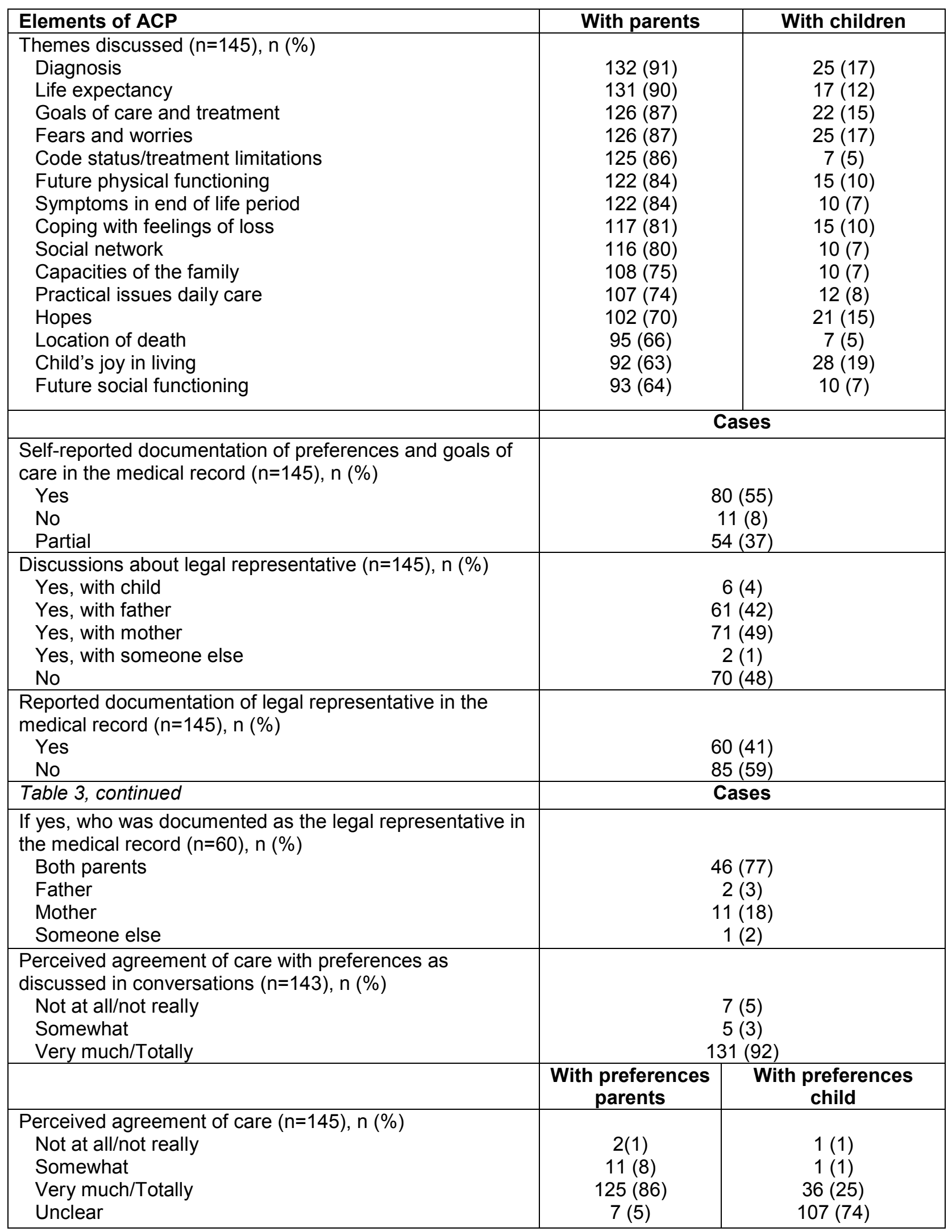




\section{Attitudes regarding ACP}

Attitudes regarding ACP in general are represented in Table 4. Sixty-six percent of the respondents reported that $A C P$ discussions are indicated in all phases of the disease trajectory. The respondents confirmed that ACP can improve the quality of care (97\%) and shared decisionmaking (98\%). They confirmed in $81 \%$ that ACP can contribute to the use of palliative care. Twenty-three percent of the participants indicated that ACP conversations occur often enough. Sixty percent of the pediatricians stated that ACP has to result in the documentation of a code status. One third (37\%) confirmed ACP conversations are mainly intended to inform children and their parents. The majority of physicians (68\%) supported the statement that ACP conversations give children and families more control.

Table 4 Attitudes regarding ACP in general

\begin{tabular}{|l|c|c|c|}
\hline Statement & $\begin{array}{c}\text { Strongly } \\
\text { disagree/disagree }\end{array}$ & Neutral & $\begin{array}{c}\text { Agree/ } \\
\text { Strongly agree }\end{array}$ \\
\hline $\begin{array}{l}\text { In current practice, ACP } \\
\text { conversations occur often enough } \\
(n=160), n(\%)\end{array}$ & $79(49)$ & $44(28)$ & $37(23)$ \\
\hline $\begin{array}{l}\text { ACP conversations improve the } \\
\text { quality of medical care } \\
(n=160), n(\%)\end{array}$ & $1(1)$ & $4(3)$ & $155(97)$ \\
\hline $\begin{array}{l}\text { ACP conversations improve the use } \\
\text { of palliative care } \\
(n=160), n(\%)\end{array}$ & $5(3)$ & $25(16)$ & $130(81)$ \\
\hline $\begin{array}{l}\text { ACP conversations have to result in } \\
\text { a documented code status or } \\
\text { treatment limitations } \\
(n=159), n(\%)\end{array}$ & $26(16)$ & $38(24)$ & $95(60)$ \\
\hline $\begin{array}{l}\text { ACP conversations are intended } \\
\text { mainly to inform child/parents } \\
(n=159), n(\%)\end{array}$ & $58(36)$ & $42(26)$ & $59(37)$ \\
\hline $\begin{array}{l}\text { ACP conversations put parents in } \\
\text { control }(n=160), n(\%)\end{array}$ & $9(6)$ & $42(26)$ & $109(68)$ \\
\hline $\begin{array}{l}\text { ACP conversations improve shared } \\
\text { decision-making } \\
(n=160), n(\%)\end{array}$ & $0(0)$ & $4(3)$ & $156(98)$ \\
\hline
\end{tabular}




\section{Barriers and facilitators}

The respondents were asked to rate previously stated factors, deemed facilitators of, and barriers to ACP. Uncertainty about life expectancy (24\%), the emotional distress of patient and family (24\%), and an inability of the child and family to assess their situation (19\%), were most commonly indicated as barriers. (Figure 1) Most commonly perceived facilitators were continuity of care by the same physician (97\%), the presence of a nurse at ACP conversations (79\%), and prior multidisciplinary consultation (74\%). (Figure 2)

Fig. 1 Frequencies of perceived barriers to ACP

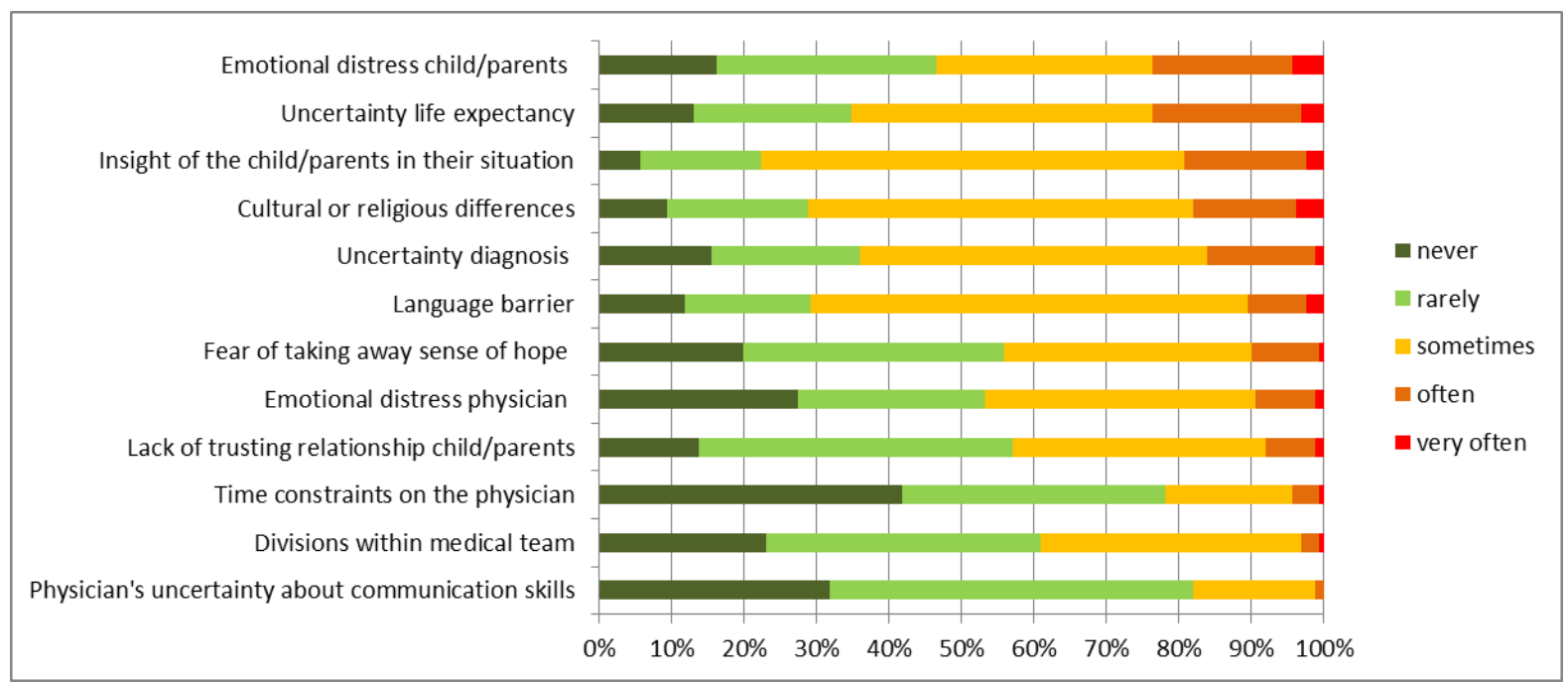

Fig. 2 Frequencies of perceived facilitators of ACP

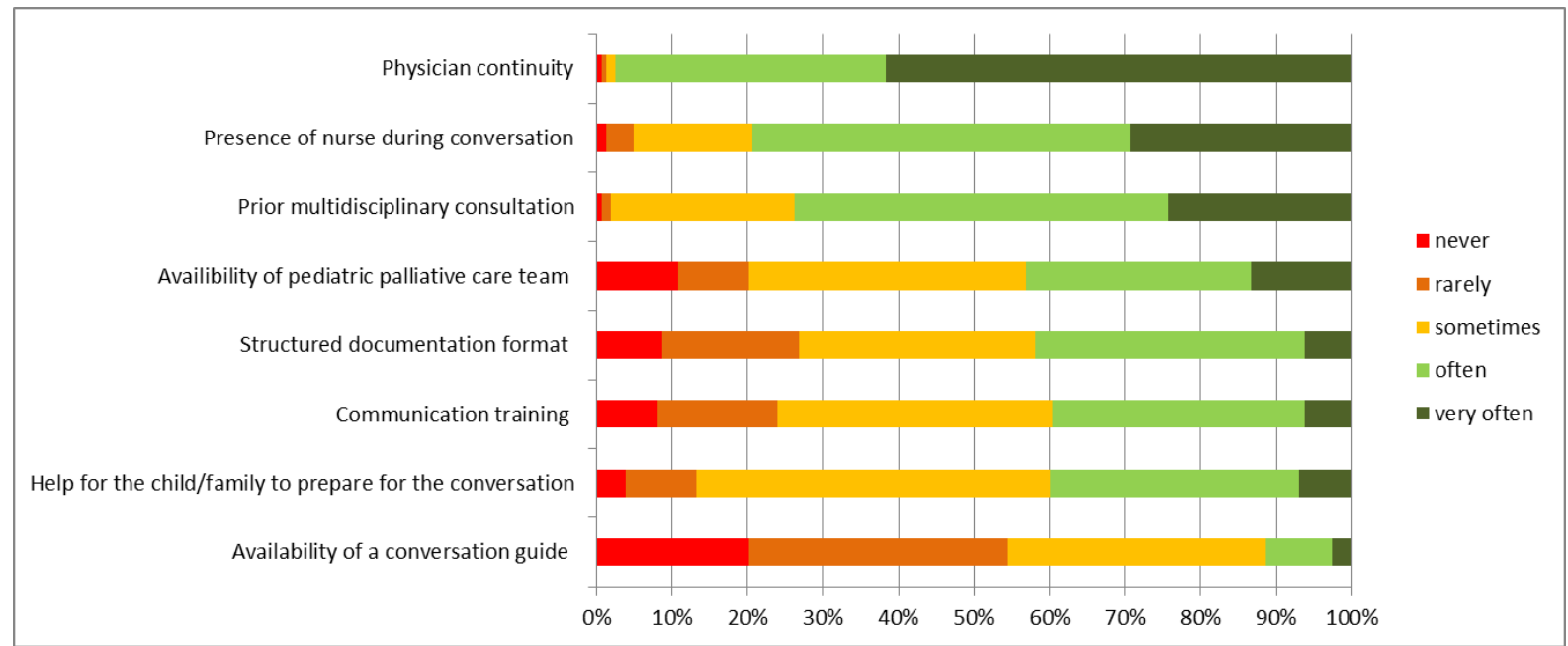




\section{Self-perception of communication skills}

Physicians indicated that they were able to explore, adequately, parent's fears, feelings and expectations in $97 \%$ of the responses, to discuss with parents bad news in $96 \%$ and code status in $91 \%$. They were also able to explore, adequately, children's' fears, feelings, and expectations in $63 \%$, discuss bad news with children in $61 \%$ and discuss a code status with a child in $52 \%$. (Figure 3) Physicians agreed in $94 \%$ that they were also able to check, adequately, the understanding of their conversation partners and to deal with emotions in the conversations in $89 \%$.

\section{Fig.3 Pediatricians' agreements with their ability to demonstrate communication skills}

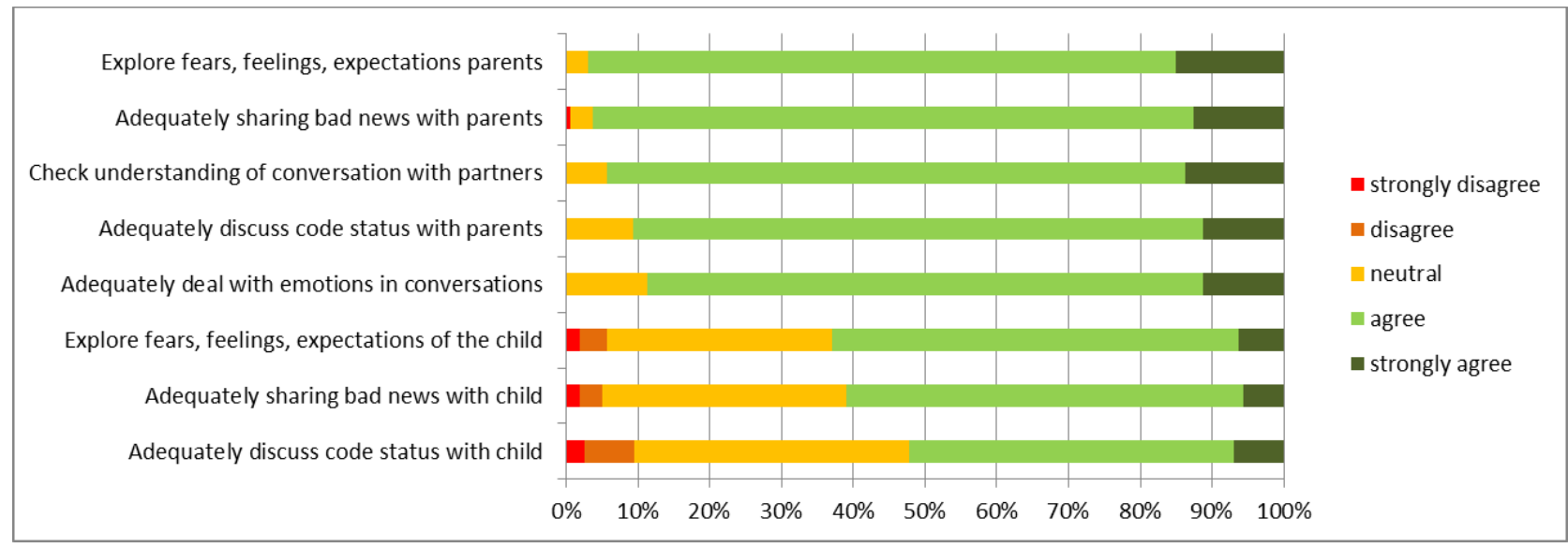

\section{Discussion}

To the best of our knowledge, this was the first survey which evaluated pediatricians' selfreported ACP behavior in actual cases. Our study elicits the following three key issues.

Firstly, although a broad range of ACP topics were reported by the pediatricians as regularly being discussed with parents, their conversations seem to predominantly focus on medical issues. In addition to this, a substantial number of pediatricians believed key elements of ACP were the provision of information and discussion of code status or treatment limitations. This might be a barrier to an early and open exploration of the family's perspective on living with a child's illness and living well. This is including the family's views on physical, psychosocial and spiritual domains. ACP originally focused on the completion of advance directives. But, today, 
there is consensus that the key elements of ACP are the exploration of personal values and preferences regarding living with an illness, now, or in the future, and sharing of these values and preferences with others., ${ }^{7,17}$ It remains unclear whether pediatricians conduct ACP conversations with families in an informative way with a focus on treatment decisions or whether they are able to engage in deeper explorations of the child's and family's underlying individual values and preferences. An analysis of the content of actual ACP conversations might give more insight into their approach.

Secondly, the exploration of the child's perspectives appears to be difficult. In our study, pediatricians reported in the majority of cases to have no insight into whether the child's preferences were in line with the care as provided. ACP conversations with children occurred in a minority of cases. Most children were considered incapable of expressing their wishes due to their young age, or because of developmental issues. However, some children were involved in the conversations about, at least, some topics, even at a very young age and without being considered competent. The involvement of children in ACP and in decision-making in general is challenging. ${ }^{18}$ Evidence about interventions to engage children in decisions related to their health is limited. A systematic review identified only five interventions, including one ACP intervention. ${ }^{19}$ Within the triad of child, parents and healthcare professionals, the perspectives and the best interests of the child need to be identified. It is of pivotal importance to support parents in their role as substitute decision-maker, because the child might be unable to present his or her own perspectives and preferences. ${ }^{4}$ In our sample, the legal representative was explicitly defined in only half of cases and infrequently documented. It seems natural in pediatrics to rely on the parents for decision-making in the best interest of the child. However, it is known that neither parents nor professionals reflect the voice of the child routinely, and even less in stressful times during the end of life phase. ${ }^{20,21}$ Although the vast majority of pediatricians were satisfied with their communications skills with regard to parents, only a small minority of physicians confirmed they had adequate skills to communicate about ACP topics with children. This is supported by findings from literature, where pediatricians felt unprepared to for discussing ACP with adolescents or conducting family conferences. ${ }^{12}$ It is known that parents too feel difficulties in discussing these issues with their children. ${ }^{20}$ 
Thirdly, although pediatricians were satisfied with their approach in the cases reported, in their communication skills in general and in particular on the benefits of ACP, only a small minority confirmed ACP conversations occur often enough. This is in line with a retrospective chart review in the United Kingdom which showed that there was no documentation of any ACP conversation in the medical record of $25 \%$ of the children approaching the end of life. ${ }^{22}$ Other research showed that more than $70 \%$ of pediatric clinicians thought that ACP discussions often occur too late. ${ }^{12,13,23} \mathrm{An}$ improvement in the frequency and timing of ACP conversations might be challenging. In our sample, pediatricians themselves see barriers to ACP mainly in parental factors. This is in line with earlier findings where parent-related factors such as unrealistic expectations, a perceived lack of parental readiness to discuss end of life issues, and not wanting to burden parents, were perceived as key barriers to ACP in paediatrics. ${ }^{8,13}$ Research suggests, however, that parents want to be involved in decision-making and many prefer open, honest and complete information about end of life care. ${ }^{24-26}$ They do not, however, always actively search for it. ${ }^{27}$ Parents consider engagement in ACP important but perceive it as difficult. They need a sensitive, affective, individualized, and gradual approach, with room for patterns of hopeful thinking. ${ }^{9,28}$ The perceived facilitators of ACP were mainly associated with the healthcare professional, with a focus on a team-based approach. This is consistent with earlier research which showed clinicians prefer to discuss end of life decisions within a medical team prior to conversations with parents. ${ }^{29}$

These key issues might indicate that interventions to support ACP in pediatrics need to focus on education about the concept of ACP and about the involvement of the child in ACP. In addition, physicians might need more insight into the background of perceived parental barriers for ACP. These barriers are persistently reported by physicians, even though parents themselves report clear preferences to ACP. The integration of multidisciplinary approaches, such as multidisciplinary consultations prior to ACP conversations, and involving different professions in the conversation itself, might be valued by pediatricians and might support them to engage in ACP more often. 


\section{Strengths and limitations}

The invitation to participate in this survey study was sent to all pediatricians working in the hospitals participating in order to prevent selection bias based on subspecialty. As a result, our study population included a broad range of pediatric subspecialties. Our broad invitation strategy might have led to a lower overall response rate. The focus on children with life-limiting conditions in the introduction of the survey might have held back some readers from participation since not all pediatricians in university care centers serve this population. Nevertheless, this aligns with the idea that response representativeness might be more important than response rate in survey research. ${ }^{30}$ The responders turned out to be a selection of experienced pediatricians with a mean working experience in pediatrics of 18.3 years. This is possibly an adequate reflection of the fact that in pediatric medical practice in the Netherlands, the more experienced professionals take care of the more complex medical cases.

Although the care for seriously ill children in the Netherlands is concentrated in the university medical care centers, these children receive care from other pediatricians and general practitioners as well. Therefore our results might underestimate the full range of ACP activities provided to seriously ill children and their families. The focus on the most recent case of a child who died might have both underestimate or overestimate current ACP activities. It could be that for an individual respondent the most recent case was not a good model for their actual ACP activities. We focused on the most recent case to prevent selection bias by the respondents. However, we could not check whether the respondents really reported on their most recent case. They might have chosen a case which came directly to mind, or a case in which they valued the conversations they have had. This may have biased the results.

In addition, our data collection did not cover any data from non-responders, which complicates comparisons between our sample and the total group of eligible participants. Another limitation of the study is that we do not know at what moment in the disease trajectory elements of ACP were discussed and with what intention. Respondents might have labelled conversations in hindsight as part of a longitudinal ACP process, whereas they, at that actual moment, did not discuss these items intentionally as part of ACP. 


\section{Conclusion}

Dutch pediatricians caring for children living with life-limiting conditions reported mainly having ACP conversations with parents. Conversations with children occur only in a minority of cases. Pediatricians acknowledge the benefits of $A C P$ and report that they are competent in ACP communication. Conversations about code status or treatment limitations are considered key parts of ACP. A minority feel that ACP conversations occur often enough. The barriers to ACP conversations are mainly perceived as related to parents. Education in the explorative nature of $A C P$, the involvement of the child in $A C P$, and parental preferences for $A C P$, might contribute to the further engagement of pediatricians in ACP. 


\section{References}

1. Fraser ALK, Miller M, Hain R, et al. Rising National Prevalence of Life-Limiting Conditions in Children in England. Pediatrics. 2012;129(4):e923-e929.

2. Feudtner C, Tammy I, Hexem KR, et al. Pediatric Palliative Care Patients: A Prospective Multicenter Cohort Study. Pediatrics. 2011;127:1094-1101.

3. Verberne LM, Kars MC, Schouten-van Meeteren AYNS, et al. Aims and tasks in parental caregiving for children receiving palliative care at home : a qualitative study. Eur $\mathrm{J}$ Pediatr. 2017;176(3):343-354.

4. Hinds PS, Oakes LL, Hicks J, et al. "Trying to Be a Good Parent" As Defined By Interviews With Parents Who Made Phase I, Terminal Care, and Resuscitation Decisions for Their Children. J Clin Oncol. 2009;27(35):5979-5985.

5. End of life care for infants, children and young people with life-limiting conditions: planning and management. NICE guideline. [Internet] Published 2016. Accessed January 14, 2019.

6. American Academy of Pediatrics. Pediatric Palliative Care and Hospice Care Commitments, Guidelines, and Recommendations. Pediatrics. 2013;132:966-972.

7. Rietjens JAC, Sudore PRL, Connolly M, et al. Review Definition and recommendations for advance care planning: an international consensus supported by the European Association for Palliative Care. Lancet Oncol. 2017;18(9):e543-e551.

8. Lotz JD, Jox RJ, Borasio GD, Führer M. Pediatric advance care planning from the perspective of health care professionals: a qualitative interview study. Palliat Med. 2015;29(3):212-222.

doi:10.1177/0269216314552091

9. Lotz JD, Daxer M, Jox RJ, Borasio GD, Führer M. " Hope for the best, prepare for the worst ": A qualitative interview study on parents' needs and fears in pediatric advance care planning. Palliat Med. 2016;31(8):764-771.

10. Brinkman-stoppelenburg A, Rietjens JAC, van der Heide A The effects of advance care planning on end-of-life care : A systematic review. Palliat Med. 2016;28(8):1000-1025.

11. de Vleminck A, Houttekier D, Pardon $K$, et al. Barriers and facilitators for general practitioners to engage in advance care planning: A systematic review. Scand J Prim Health Care. 2013;32(October):215-226.

12. Sanderson A, Hall AM, Wolfe J. Advance Care Discussions: Pediatric Clinician Preparedness and Practices. J Pain Symptom Manage. 2016;51(3):520-528.

13. Durall A, Zurakowski D, Wolfe J. Barriers to conducting advance care discussions for children with life-threatening conditions. Pediatrics. 2012;129(4):e975-82.

14. van der steen JT, Kruse RL, Ooms ME, et al. Treatment of Nursing Home Residents with Dementia and Lower Respiratory Tract Infection in the United States and the Netherlands: An ocean apart. JAGS. 2004;52:691-699.

15. Ajzen I. The theory of plannend behavior. Organ Behav Hum Dec. 1991;50:179-211.

16. Kars M, Grypdocnk M, van Delden JJM. Being a Parent of a Child With Cancer Throughout the End-of-Life Course. Oncol Nurs Forum. 2011;38(4):2011. 
17. Fahner JC, Beunders AJM, van der Heide A, et al. Interventions Guiding Advance Care Planning Conversations : A Systematic Review. J Am Med Dir Assoc. 2019;20(3):227-248.

18. Hein IM, Troost PW, Broersma A, de Vries MC, Daams JG, Lindauer RJL. Why is it hard to make progress in assessing children's decision-making competence? BMC Med Ethics. 2015;16(1):1-6.

19. Feenstra B, Boland L, Lawson ML, et al. Interventions to support children's engagement in healthrelated decisions: a systematic review. BMC Pediatr. 2014;14:109.

20. Kars MC, Grypdonck M, de Bock L, van Delden JJM. The parents' ability to attend to the "voice of their child" with incurable cancer during the palliative phase. Heal Psychol. 2015;34(4):446-452.

21. Bluebond-langner M, Belasco JB, Goldman A, Belasco C. Understanding Parents' Approaches to Care and Treatment of Children With Cancer When Standard Therapy Has Failed. $J$ Clin Oncol. 2007;25(17):2414-2419.

22. Heckford E, Beringer AJ. Advance Care Planning: Challenges and Approaches for Pediatricians. $J$ Palliat Med. 2014;17(9):1049-1053.

23. Basu S, Swil K. Paediatric advance care planning: Physician experience and education in initiating difficult discussions. J Pediatr Child Heal. 2017;54(5):510-514.

24. de Vos MA, Bos AP, Plötz FB, van Heerde M, de Graaff BM. Talking With Parents About End-ofLife Decisions for Their Children. Pediatrics. 2015;135(2):e465-e467.

25. Meyer EC, Ritholz MD, Burns JP, Truog RD. Improving the quality of end-of-life care in the pediatric intensive care unit: parents' priorities and recommendations. Pediatrics. 2006;117(3):649-657.

26. Gordon C, Barton E, Meert KL, Eggly S. Accounting for medical communication: Parents' perceptions of communicative roles and responsibilities in the pediatric intensive care unit. Commun Med. 2012;6(2):177-188.

27. Kars MC, Grypdocnk M, de Korte-Verhoef M, et al. Parental experience at the end-of-life in children with cancer: ' preservation ' and 'letting go ' in relation to loss. Support Care Cancer. 2011;19:27-35.

28. Feudtner C, Carroll KW, Hexem, Kari R, Silberman J, Kang TI, Kazak AE. Parental Hopeful Patterns of Thinking, Emotions, and Pediatric Palliative Care Decision Making. Arch Pediatr Adolesc Med. 2010;164(9):831-839.

29. de Vos MA, van der Heide A, Maurice-stam H, et al. The Process of End-of-Life Decision-Making in Pediatrics: A National Survey in the Netherlands. Pediatrics. 2011;127:e1004-e1012.

30. Cook C, Heath F, Thompson RL. A meta-analysis of response rates in web- or Internet-based surveys. Educ Psychol Meas. 2000;60(6):821-836.

\section{Appendices}

Questionnaire survey study 
Chapter 5

Towards advance care planning in pediatrics: a qualitative study on envisioning the future as parents of a seriously ill child

\author{
Jurrianne C. Fahner \\ Thessa W. Thölking \\ Judith A.C. Rietjens \\ Agnes van der Heide \\ Johannes J.M. van Delden \\ Marijke C. Kars
}

Eur J Pediatr. 2020 Mar 19. doi: 10.1007/s00431-020-03627-2. Online ahead of print. 


\section{Abstract}

Advance care planning enables parents to discuss goals and preferences for future care and treatment of their seriously ill child. Although clinicians report parental factors as common barriers for advance care planning, parental views on reflecting on their child's future have had limited exploration. A clear understanding of their perspectives might help clinicians to implement advance care planning tailored to parental needs. This interpretive qualitative study using thematic analysis aims to identify how parents envision the future when caring for their seriously ill child. Single interviews and two focus groups were attended by 20 parents of 17 seriously ill children. Parents reported to focus on the near future of their child. However, their actions and deeper thoughts showed perspectives towards a further future. Future perspectives initial focused on practical, disease-related themes, but more existential elaborations, reflecting underlying life values, were also identified. Parents needed acknowledgement of their challenging situation, care tasks and expertise as a precondition for sharing their deepest thoughts regarding the future of their child.

Conclusion: When envisioning the future of their seriously ill child, parents tend to stay in the near future, whereas they value the opportunity to share further thoughts within a compassionate relationship with clinicians. 


\section{Introduction}

As survival rates have improved in pediatric care due to medical and technological advances, the number of children and young adults living with life-limiting conditions has increased over time. $^{1}$

These children and their families are in need of palliative care, and often need support in decision making about future treatment and care. ${ }^{2}$ However, early integration of palliative care discussions remains challenging. A qualitative interview study from Hungary showed that physicians tend to place palliative care at the end of a disease trajectory, when there are no curative options left. ${ }^{3}$ Advance care planning (ACP) aims to facilitate early planning of future treatment and care, including end-of-life care, through exploration and understanding of individual values, preferences and goals for care and treatment. ${ }^{4}$

Although research on pediatric ACP is still in its infancy, emerging evidence suggests that families and clinicians value the concept of ACP, even earlier in disease trajectories than is customary practice. $^{5-11}$

However, it has also been established that parents, whilst valuing ACP greatly, simultaneously experience ACP as emotional. ${ }^{8}$ Clinicians' receptiveness to parental feelings of unease poses a barrier to initiate ACP conversations with parents. ${ }^{9,12-14}$ Consequently, although both parents and clinicians contemplate future care, a substantial exchange of their perspectives does not seem to occur sufficiently. ${ }^{12,13,15}$ So far, current literature focusses on the experiences of bereaved parents, mainly within the end-of-life phase. ${ }^{8,11}$

To engage parents and medical teams in ACP, clinicians need a profound understanding of parental preferences towards anticipating and discussing the future. Insight into parental experiences and perspectives regarding the future, both early and late in a disease trajectory, is lacking. Therefore, this study aims to elucidate how parents of children with life-limiting conditions, contemplate the future and under which conditions parents share these future perspectives with clinicians caring for their child. 


\section{Methods}

To elucidate parents' perspectives on contemplating the future, we conducted an interpretative qualitative interview study using an inductive thematic analysis. ${ }^{16-18}$ The COmprehensive consolidated criteria for REporting Qualitative research (COREQ) were used to structure the study report. ${ }^{19}$

\section{Sample}

A purposive sample of Dutch-speaking parents of children diagnosed with a life-limiting condition less than 18 years of age was included. To capture a wide range of perspectives, variation was sought with respect to the parent's gender and education, the child's diagnosis, stage of illness, life expectancy and age. Both bereaved and non-bereaved parents were eligible. Bereaved parents were included as they are able to reflect on their thoughts about their child's future in retrospect, while overseeing their child's whole disease trajectory, including end of life. Pediatricians in one university medical center and two peer supporters introduced the study to parents and asked permission for the researchers to contact them.

\section{Data collection}

Parents were offered a choice to participate in a prescheduled focus group interview or an individual face-to-face interview. The interviews took place between June 2018 and March 2019. Individual interviews were scheduled at a location and time as preferred by the parents. The two focus group interviews were moderated by JF (trained qualitative researcher, MD) and MCK (experienced qualitative researcher, RN). JF conducted the individual interviews. The interviews were guided by a topic list, which was based on literature and expert knowledge. The topics included future time frame, future perspectives, sharing of future perspectives, future goal setting and decision making. Interviews were audio recorded and transcribed verbatim. Parent and child demographic variables were collected through an additional questionnaire. The research ethics committee of the University Medical Center Utrecht determined that this study was exempt from the Medical Research Involving Humans Act (September 27, 2017; Reference number: 17-662/C). All participants provided written informed consent. 


\section{Data analysis}

A thematic analysis was performed. ${ }^{16}$ During the entire process, three researchers (JF, TT, MCK) were involved. Researcher triangulation was ensured to improve reliability and validity of the analysis. The thematic analysis consisted of three phases. ${ }^{17,18}$ First, the core researchers (JF, TT, MCK) individually (re)read the transcripts of five individual interviews to get familiar with common aspects and phrases. Two researchers (JF, TT) individually analyzed and coded meaningful fragments in the light of the research question and compared interpretations together. The meaning of the separate text fragments was determined by interpreting them in light of the whole interview. ${ }^{20}$ Initial codes were recoded, resulting in an adapted code list with themes and concepts at a more conceptual level. ${ }^{16}$ During the second phase, new interviews were read and discussed by two researchers (JF, TT). One researcher (JF) coded all transcripts, supported by the software program Nvivo 11. The code tree was evaluated and adjusted. Lastly, the research team (JF, TT, MCK) identified key themes and related subthemes. The researchers went back and forth between the different steps to guarantee constant comparison. Code saturation was reached on a conceptual level. ${ }^{21}$

\section{Results}

In total, 20 parents of 17 children were interviewed. Ten parents attended a focus group interview of five participants each. Individual interviews took place in the hospital $(n=8)$, at home $(n=1)$ and at the parent's workplace $(n=1)$. The interviews lasted from 30 minutes to three hours. For respondent characteristics, see Table 1. 
Table 1. Parent and child characteristics

\begin{tabular}{|c|c|}
\hline & n (\%) \\
\hline \multicolumn{2}{|l|}{ Parent characteristics $(n=20)$} \\
\hline Female & $15(75)$ \\
\hline $\begin{array}{l}\text { Age } \\
\begin{array}{l}30-40 \text { years } \\
40-50 \text { years } \\
>50 \text { years }\end{array}\end{array}$ & $\begin{array}{l}9(45) \\
8(40) \\
3(15)\end{array}$ \\
\hline $\begin{array}{l}\text { Marital stage } \\
\text { Married/cohabiting } \\
\text { Not cohabiting }\end{array}$ & $\begin{array}{c}18(90) \\
2(10)\end{array}$ \\
\hline Caucasian race & $20(100)$ \\
\hline $\begin{array}{l}\text { Level of education } \\
\text { Secondary school } \\
\text { Vocational education } \\
\text { High school } \\
\text { University } \\
\end{array}$ & $\begin{array}{l}1(5) \\
4(20) \\
6(30) \\
9(45) \\
\end{array}$ \\
\hline $\begin{array}{l}\text { Religion } \\
\text { Protestant } \\
\text { None }\end{array}$ & $\begin{array}{c}11(55) \\
9(45)\end{array}$ \\
\hline Child characteristics ( $n=17)$ & \\
\hline Female & $5(30)$ \\
\hline $\begin{array}{c}\text { Deceased } \\
\text { Total }\end{array}$ & $6(35)$ \\
\hline $\begin{array}{l}<2000 \\
2000-2010 \\
>2010\end{array}$ & $\begin{array}{l}1(17) \\
1(17) \\
4(67)\end{array}$ \\
\hline $\begin{array}{l}\text { Age at death/at interview } \\
<1 \text { year } \\
1-5 \text { years } \\
5-12 \text { years } \\
>12 \text { years }\end{array}$ & $\begin{array}{l}3(18) \\
6(35) \\
5(29) \\
3(18)\end{array}$ \\
\hline $\begin{array}{l}\text { Diagnosis } \\
\text { Chromosomal anomaly } \\
\text { Congenital heart disease } \\
\text { CNS tumor } \\
\text { Cystic Fibrosis } \\
\text { Neuromuscular disease } \\
\text { Epilepsy syndrome } \\
\text { Perinatal asphyxia }\end{array}$ & $\begin{array}{l}7(41) \\
4(24) \\
2(12) \\
1(6) \\
1(6) \\
1(6) \\
1(6) \\
\end{array}$ \\
\hline $\begin{array}{l}\text { Age at diagnosis } \\
<1 \text { year } \\
1-5 \text { years } \\
>5 \text { years }\end{array}$ & $\begin{array}{l}12(71) \\
3(18) \\
2(12)\end{array}$ \\
\hline
\end{tabular}




\section{Attitudes towards the future}

All parents expressed some thoughts about the future of their child and family. Several triggers stimulated them to contemplate the future. These were often disease-related triggers, like upcoming medical evaluations, procedures or decision making. Besides that, questions about the child's development in the context of his or her disease, stimulated parents to think about the future. Triggers could also be related to safeguarding the continuity of care. Parents reported external triggers, like changes in laws and financial support, and internal triggers, such as worries about the long-term task of caregiving and related parental burden of care. Lastly, parents mentioned that existential questions stimulated them to think about the future of their child. These questions could arise from prior experiences with illness, death and dying or from their spiritual beliefs. These questions made parents think about their underlying values and influence of these values on future decision making.

Four main themes were identified when parents were asked to envision the future of their child. It was seen that 1 ) there is a focus on the near future; 2 ) future perspectives are intertwined with experiences in the present and the past; 3) future perspectives range from a disease-related orientation to a value-based orientation; and 4) there is 'no sharing without caring'. Representative quotations were chosen to illustrate the identified themes. (Table 2) Perspectives on the future while caring for a seriously ill child as described below were quite similar for both bereaved and non-bereaved parents.

\section{Focus on the near future}

Although many parents said to live one day at a time, they could not neglect future perspectives. As parents expressed thoughts about the future of their child and family, they focused on the near future initially. They felt being withheld from looking further ahead by recurrent episodes of clinical deterioration of their child, prognostic uncertainty, upcoming medical procedures and the actual burden of daily care giving. (Table 2, Quote 1A) Although most parents limited their reflections to the near future initially, they showed contemplation of a further future in actions they reported. These actions showed that parents prepare themselves, at least in a practical way, for a further future where deterioration of their child's condition might 
occur. For example, these were practical arrangements for the child's death (Table 2, Quote 1B) and integration of certain facilities in a rebuilding plan for their homes.

Intertwinement of future perspectives with experiences in the present and the past

When parents shared perspectives about the future in the interviews, it was seen that these perspectives were very intertwined with experiences in the present and the past. First, the content of their future perspectives was influenced by their attitude towards the current situation. Parents who were suffering and struggling in the present, tended to see the future as a black box, while parents with a consistent, balanced view on the actual situation of their child could more easily look forward. This did not seem to be related to an either better or worse prognosis. (Table 2, Quote 2A) Besides that, in case of experiencing more prognostic certainty in the present, either better or worse, parents showed more ability to elaborate on the future. If future scenario's seemed realistic to parents, they were more tempted to reflect on those situations, even though it confronted them with unfavorable outcomes for their child. (Table 2, Quote 2B) Some parents mentioned that feeling at peace with intense end-of-life experiences in the past, made them more open-minded to think and discuss about a future where similar scenarios could occur. (Table 2, Quote 2C) Few parents envisioned the future in relation to decisions made in the past. This made them think about the life they could have had as a family, if only they had made different choices in the past. These elaborations were followed by thoughts about all the good things being a parent of their seriously ill child had brought them. These positive thoughts supported them to face the future. (Table 2, Quote 2D) Some parents experienced a connection between past, present and future based on their life views and spiritual beliefs. They framed their perspectives on the future as part of a continuing life story, influenced by a higher power, like God. (Table 2, Quote 2E)

Future perspectives range from a disease-related orientation to a values-based orientation

Most parents mentioned practical, disease-related perspectives at first, when asked about their views on the future. Common topics were disease progression, next medical evaluations, the child's development, financing the care costs, safe-guarding care at home, maintaining family life and organization of multidisciplinary care. (Table 2, Quote 3A) When asked about their 
thoughts on the future most parents did not talk spontaneously about underlying life views, values, hopes, fears and worries. However, when specifically asked about, they presented all sorts of reflections on more existential themes. Hopes for the future could be concrete, realistic hopes or wishes and dreams that were to be cherished. (Table 2, Quote 3B) Fears and worries regarding the future concerned the loss of their child to death, facing difficult decisions, possible suffering of the child, the ongoing heavy burden of care and achieving a life as normal as possible for their child. Some parents expressed that addressing these fears was emotional and burdensome to them. Recognizing or discussing their fears confronted parents with worst-case scenarios as a reality and disrupted their coping strategy of focusing on the here and now. However, parents demonstrated this made them not unwilling to contemplate the future. It enabled them to prevent or prepare themselves for a feared situation and left them with a greater peace of mind in the present. Some parents mentioned in hindsight they would have valued more attention to their fears, because they felt overwhelmed and unprepared when a worst-case scenario occurred.

When parents were asked about future care goals for their child a distinction between diseaserelated aims and value-based aims was seen as well. Some parents had clear short-term disease-related aims, such as correction of a tracheostomy. These parents could more easily formulate goals of future care. Parents who reported broader, all-encompassing, value-based aims for their child, such as being happy or trying to live an ordinary life, had more difficulties to demonstrate how these aims could guide them to formulate goals of future care. (Table 2, Quote 3C) Some parents mentioned that taking the perspective of their child, like 'what would my child value the most', helped them to define goals of future care and treatment.

Most parents recalled discussions about treatment limitations when thinking about future goals of care. They showed to experience these discussions as touching their underlying values, whereas clinicians framed these discussions more in the context of the child's disease and any medical futility. (Table 2, Quote 3D) Some parents addressed treatment limitations themselves because they considered this an essential part of what they valued as good care for their child. However, parents emphasized they would prefer clinicians to initiate these discussions, because 
the accompanying emotional distress could be a parental barrier to initiate a conversation about treatment limitations.

\section{No sharing without caring}

Although all parents presented elaborate thoughts about the future of their child during the interviews, few said to have discussed the rich content of these thoughts with their clinicians. Several factors were identified that would support sharing of future perspectives with clinicians. First, parents mentioned they need acknowledgment of their challenging context. Parents expressed they felt clinicians have no idea of the impact of caring for a seriously ill child on their daily life. They showed a need for acknowledgement of the burden of care that is on their shoulders. (Table 2, Quote 4A) Second, parents want their growing expertise to be acknowledged and be taken into account when it comes to medical decision making. (Table 2, Quote 4B) Most parents felt a struggle to be treated as the expert of their child. Some parents felt being judged for their perspectives on their child's future and feared unintended consequences for their child's care, without opportunities for reconsideration. Third, parents reported little room to share perspectives outside the medical domain, although they would appreciate it. (Table 2, Quote 4C) Besides that, parents expressed to value clinician's awareness of the child's identity apart from his or her disease. (Table 2, Quote 4D) When their child was seen as an individual person, with an own life story, they felt sharing perspectives on their child's future with clinicians made more sense.

Lastly, parents expressed a need for a consistent approach of clinicians regarding future care and treatment over time and among different disciplines. Parents reported to struggle to get all clinicians on the same page. If parents felt a shared goal within the team and felt part of the team, this positively influenced their openness to share their perspectives. (Table 2, Quote 4E) 
Table 2. Quotes that illustrate parental attitudes towards the future and sharing of future perspectives

\begin{tabular}{|c|c|}
\hline (sub)Theme & Quote \\
\hline \multicolumn{2}{|l|}{ Focus on the near future } \\
\hline $1 \mathrm{~A}$ Initial orientation on the near future & $\begin{array}{l}\text { R20: mother of a girl, } 6 \text { years, MD. "Our live was } \\
\text { really divided into periods until the next MRI. I } \\
\text { could not look further than the next scan, no way. I } \\
\text { got angry or anxious when we got invitations for } \\
\text { events scheduled after that period." }\end{array}$ \\
\hline 1B Preparatory actions show further perspectives & $\begin{array}{l}\text { R3: mother of a boy, } 3 \text { months, NMD. "Not to } \\
\text { prepare everything in detail, but I bought clothes } \\
\text { for him to wear in the coffin, you know?... And then } \\
\text { I put them away in a bag over there." }\end{array}$ \\
\hline \multicolumn{2}{|l|}{$\begin{array}{l}\text { Intertwinement of future perspectives with } \\
\text { experiences from the present and the past }\end{array}$} \\
\hline $\begin{array}{l}\text { 2A Future perspectives are related to the current } \\
\text { situation }\end{array}$ & $\begin{array}{l}\text { R7: father of a boy, } 4 \text { years, NDM. "He already } \\
\text { survived his own prognosis. We are going to help } \\
\text { him stay the longest-living infant with this } \\
\text { syndrome." }\end{array}$ \\
\hline $\begin{array}{l}\text { 2B Prognostic certainty stimulates thinking about } \\
\text { worst-case scenarios further away }\end{array}$ & $\begin{array}{l}\text { R13: mother of a girl, } 1 \text { year, NMD. "The doctors } \\
\text { are just really sad about her future. We distinctly } \\
\text { discussed how we will.... what we will do when she } \\
\text { loses consciousness [during an event at home]. } \\
\text { Shall we call the doctor, or will take her in our } \\
\text { arms, where she will pass away?" }\end{array}$ \\
\hline $\begin{array}{l}\text { 2C Future perspectives are related to experiences } \\
\text { from the past }\end{array}$ & $\begin{array}{l}\text { R6: mother of a boy, } 4 \text { years, NMD. "We proved } \\
\text { with our other child [parents lost another child with } \\
\text { the same diagnosis after withdrawal of life } \\
\text { sustaining treatment], grimly said, that we are } \\
\text { capable of taking a child off the ventilator. That } \\
\text { somehow grants you the confidence that, even } \\
\text { though you never thought you would be capable of } \\
\text { doing that, you might be able to do it again." }\end{array}$ \\
\hline $\begin{array}{l}\text { 2D Prior decision making influences attitude } \\
\text { towards the future }\end{array}$ & $\begin{array}{l}\text { R1: mother of a boy, } 1 \text { year, NMD. "If we [...] } \\
\text { would have known everything, that it would be so } \\
\text { tough, we would have [...] not carried to term. In } \\
\text { hindsight. But at that time you didn't know. But it is } \\
\text { so beautiful to know him. You would not have } \\
\text { known that it could be so beautiful.. So he keeps } \\
\text { you going... there is nothing else to do.. }\end{array}$ \\
\hline 2E Life views connect past, present and future & $\begin{array}{l}\text { R13: mother of a girl, } 1 \text { year, NMD. "This we really } \\
\text { know...that eventually her life is simply in God's } \\
\text { hands and He knows. He knew her beginning and } \\
\text { He knows her end, her life's end. And we hope it } \\
\text { [her life] will not end sometime soon." }\end{array}$ \\
\hline \multicolumn{2}{|l|}{$\begin{array}{l}\text { Future perspectives range from a disease- } \\
\text { related orientation to value-based orientation }\end{array}$} \\
\hline 3A An initial practical, disease-related orientation & $\begin{array}{l}\text { R11: mother of a boy, } 6 \text { years, NDM. "On the one } \\
\text { hand there is this question: 'how long will his future } \\
\text { be?' and on the other hand 'how are we going to } \\
\text { fulfil his care needs?" }\end{array}$ \\
\hline $\begin{array}{l}\text { 3B More existential thoughts emerge in deeper } \\
\text { conversations }\end{array}$ & $\begin{array}{l}\text { R13: mother of a girl, } 1 \text { year, NMD. "Yes, I would } \\
\text { really love to see a little bit of development, just a }\end{array}$ \\
\hline
\end{tabular}




\begin{tabular}{|c|c|}
\hline & $\begin{array}{l}\text { little bit of interaction [with her daughter], but } \\
\text { actually I do not really hope for it anymore, } \\
\text { because I don't believe it will happen. It is more } \\
\text { like a wish." }\end{array}$ \\
\hline 3C Defining future goals of care needs deliberation & $\begin{array}{l}\text { R11: mother of a boy, } 6 \text { years, NDM. "Uhm, well... } \\
\text { Look, in the ideal situation we would prevent big } \\
\text { problems, more big problems, in the future. But if } \\
\text { you are talking about cure [as opposed to care], } \\
\text { this is a difficult thing, because you can't foresee } \\
\text { what will cross your path in the future." }\end{array}$ \\
\hline $\begin{array}{l}\text { 3D Discussing treatment limitations touches } \\
\text { underlying values }\end{array}$ & $\begin{array}{l}\text { R5: mother of a boy, } 3 \text { years, NMD. 'Unjustly, the } \\
\text { question whether it has been enough or whether } \\
\text { we should continue treatment is asked about him } \\
\text { very often...Other children are very ill as well and } \\
\text { sometimes unhappy, but no one dares to ask this } \\
\text { question in their case... While with [her son] it is } \\
\text { asked all the time... That is quite confrontational... } \\
\text { very painful.... (R5) }\end{array}$ \\
\hline \multicolumn{2}{|l|}{ No sharing without caring } \\
\hline $\begin{array}{l}\text { 4A Need for acknowledgment challenging parental } \\
\text { context }\end{array}$ & $\begin{array}{l}\text { R10: father of a girl, } 7 \text { years, NMD. "I am always } \\
\text { feeling ill and on the move, and you can just see } \\
\text { that I won't make it. You can see how my engine is } \\
\text { starting to fail..."(R10) }\end{array}$ \\
\hline $\begin{array}{l}\text { 4B Need for acknowledgment growing parental } \\
\text { expertise }\end{array}$ & $\begin{array}{l}\text { R7: father of a boy, } 4 \text { years, NMD. "When I call the } \\
\text { neurologist to say it is not OK with my son's } \\
\text { epilepsy, than he will take some action. He will not } \\
\text { ask any further questions, but trusts me in my } \\
\text { observation the epilepsy is getting worse and } \\
\text { something has to be done about it. }\end{array}$ \\
\hline $\begin{array}{l}\text { 4C Attention to perspectives outside the medical } \\
\text { domain }\end{array}$ & $\begin{array}{l}\text { R5: mother of a boy, } 3 \text { years, NMD. "I would } \\
\text { appreciate it [to discuss matters out of the medical } \\
\text { domain]. His emotional wellbeing and his } \\
\text { development are part of who he is. }\end{array}$ \\
\hline 4D Awareness of the child's identity & $\begin{array}{l}\text { R5: mother of a boy, } 3 \text { years, NMD. "He is not just } \\
\text { a respiratory infection, he is simply a human } \\
\text { being." }\end{array}$ \\
\hline $\begin{array}{l}\text { 4E Need for consistency towards shared care } \\
\text { goals }\end{array}$ & $\begin{array}{l}\text { R2: mother of a boy, } 3 \text { months, NMD. "I believe } \\
\text { that as long as the shared goal is being put } \\
\text { forward, you are already halfway there. Then you'll } \\
\text { have an understanding of each other [parents and } \\
\text { clinicians], respect each other and appreciate each } \\
\text { other deeply." }\end{array}$ \\
\hline
\end{tabular}

\section{Discussion}

When envisioning the future of their seriously ill child, parents tended to stay close to the here and now. However, parents showed to experience thoughts that go beyond the present, even beyond their child's death, and they reported activities showing preparations for a further future. When sharing future perspectives, parents focused on practical and disease-related 
themes initially. More existential, value-based perspectives were shared less spontaneously, mostly after being specifically asked about. However, parents reported to value opportunities to share their deepest thoughts with clinicians. When parents experienced a relationship of trust and reciprocity with their clinician and felt acknowledged as experts of their child, they shared more elaborate thoughts about the future with their clinician.

Sharing of preferences and goals for future care is a key element of ACP. The main findings of our study provide some insights that might be useful for the further development and implementation of pediatric ACP. First, whereas ACP aims to discuss future situations, parents might need a stepwise approach that begins close to their actual situation. With the current tendency to initiate ACP early in a disease trajectory, ${ }^{4}$ aiming to oversee a future which is further away, it becomes even more important to achieve a shared understanding of the child's illness and the actual situation as a first step in ACP. ${ }^{22-24}$ This need for an initial focus on diseaserelated issues when discussing the future, is in line with earlier research, where the strive for controlled symptoms and controlled disease was the key parental aim. ${ }^{25}$ Another study identified taking control as one out of four coping strategies of parents who take care of their child receiving palliative care and found that taking control reduced emotional distress. ${ }^{26}$ In our study, parents who showed to feel in control over their daily live and care tasks, seemed to be able to overview the future more easily, whereas parents who were struggling in their parenting role had more difficulties to achieve a thorough perspective on the future. Our study suggests that sharing of future perspectives in the context of the actual situation, supports parents to identify what really matters to them and where they should focus on together with the clinical team. Consequently, sharing these thoughts with clinicians showed to support parents in pursuing their goals and meeting their needs. ${ }^{8,11}$

Second, parents in our study reported that they did not naturally share their more existential thoughts with clinicians. Contemplating more sensitive issues regarding the future, like hopes, fears and worries, is a demanding and, sometimes burdensome endeavor to parents. ${ }^{8}$ However, this parental unease does not reflect unwillingness to talk about these issues. Therefore, it should not be seen as a barrier for ACP, although clinicians tend to do so. ${ }^{12}$ Findings from our 
study indicate that parents might not experience sufficient opportunities from clinicians to share their deepest thoughts regarding the future. Whereas ACP includes the physical, psychological, social, and spiritual domain, ${ }^{27}$ parents might not expect clinicians to show interest in all these domains. In that way both parents and clinicians continue to focus on medical issues, leaving other domains undisclosed. This might complicate a shared understanding of future care goals and hinder shared decision making. Conversation guidelines may help clinicians to address existential issues in the context of ACP. ${ }^{24,28}$

Third, in line with earlier research, the results of this study underline the importance of a trustful relationship between parents and clinicians when sharing future perspectives. ${ }^{8,29}$ Our study adds that parents need to feel cared for as a precondition to share future perspectives. This applies in particular to sharing of deeper, personal perspectives. It is known that parents have mixed experiences in their relationships with clinicians. ${ }^{26}$ Parents in our study showed clear factors that influences this relationship positively. Clinicians, who take these factors into account when discussing the future with parents, might create more openness and deeper insight in parental preferences and underlying values. Ongoing research continues to report that key barriers for ACP as perceived by clinicians, are, in their perspective, related to parental factors. ${ }^{30}$ Our study illustrates that those perceived barriers need to be approached from a different point of view. Parents may indeed face challenges when thinking about and sharing future perspectives, but they value attention to their deepest fears and worries, and can reflect on what they need in sharing future perspectives. These insights can be helpful for clinicians to approach parents in an appropriate way, instead of refrain from ACP, based on perceived parent related barriers.

This study had some strengths and limitations. Our study included both non-bereaved and bereaved parents, whereas research in this field is often based on experiences of bereaved parents alone. ${ }^{8,11}$ We considered both perspectives valuable. Non-bereaved parents share their current experiences, while actual facing a challenging future. However, their current coping strategies might influence their perspectives. ${ }^{26}$ Bereaved parents can reflect on their child's endof-life. Despite the influence of recall bias and coping with bereavement, they can reflect on what they wish that could have gone differently. Our study did not focus primarily on 
experiences with ACP itself, as has been studied before, ${ }^{8,11}$ but focused on how parents envision the future when caring for a seriously ill child and on their attitude regarding sharing of future perspectives with others. This knowledge might support further research to develop strategies to implement ACP in pediatrics and align ACP to parental needs. Our findings might be limited by the diversity of interview settings. Some parents were interviewed during admission of their child, which might have influenced their perspectives. A shorter duration of some interviews, due to other appointments of the respondents, might have caused parents to refrain from exposing their vulnerability through complete openness. However, this might be a reflection of daily practice, were all kind of actualities effect conversations about future care. Other limitations were the recruitment of some parents by peer supporters and the predominantly participation of highly-educated mothers, which may have biased the results.

\section{Conclusion}

All parents in our study contemplated the future to varying degrees of extend, with a primary focus on the near future. However, exploration of deeper thoughts and occurrence of preparatory actions revealed a scope to a further future. Future perspectives are intertwined with experiences in the present and the past. Sharing perspectives towards the future within a trustful relationship between parents and clinicians can give deeper insight in family values, preferences and goals for future care. 


\section{References}

1. Fraser ALK, Miller M, Hain R, et al. Rising National Prevalence of Life-Limiting Conditions in Children in England. Pediatrics. 2012;129(4):e923-e929.

2. Feudtner C, Tammy I, Hexem KR, et al. Pediatric Palliative Care Patients: A Prospective Multicenter Cohort Study. Pediatrics. 2011;127:1094-1101.

3. Nyirő J, Zörgő S, Enikő F, Hegedűs K HP. The timing and circumstances of the implementation of pediatric palliative care in Hungarian pediatric oncology. Eur J Pediatr. 2018;177:1173-1179.

4. Rietjens JAC, Sudore PRL, Connolly M, et al. Review Definition and recommendations for advance care planning: an international consensus supported by the European Association for Palliative Care. Lancet Oncol. 2017;18(9):e543-e551.

5. Lyon ME, Dallas RH, Garvie PA, et al. Paediatric advance care planning survey: a cross-sectional examination of congruence and discordance between adolescents with HIV/AIDS and their families. BMJ Support Palliat Care. 2017;(2):bmjspcare-2016-001224.

6. Jacobs S, Perez J, Cheng YI, Sill A, Wang J, Lyon ME. Adolescent end of life preferences and congruence with their parents' preferences: Results of a survey of adolescents with cancer. Pediatr Blood Cancer. 2015;62(4):710-714.

7. Lotz JD, Jox RJ, Borasio GD, Führer M. Pediatric advance care planning: A systematic review. Pediatrics. 2013;131(3):e873-e880.

8. Lotz JD, Daxer M, Jox RJ, Borasio GD, Führer M. " Hope for the best, prepare for the worst ": A qualitative interview study on parents ' needs and fears in pediatric advance care planning. Palliat Med. 2016;31(8):764-771.

9. Lotz JD, Jox RJ, Borasio GD, Fuhrer M. Pediatric advance care planning from the perspective of health care professionals: a qualitative interview study. Palliat Med. 2015;29(3):212-222.

10. Myers J, Cosby R, Gzik D, et al. Provider Tools for Advance Care Planning and Goals of Care Discussion: A Systematic Review. Am J Hosp Palliat Med. 2018;35(8):1123-1132.

11. Decourcey DD, Silverman M, Oladunjoye A, Wolfe J. Advance Care Planning and Parent-Reported End-of-Life Outcomes in Children, Adolescents, and Young Adults With Complex Chronic Conditions. Crit Care Med. 2019 Jan;47(1):101-108.

12. Durall A, Zurakowski D, Wolfe J. Barriers to conducting advance care discussions for children with life-threatening conditions. Pediatrics. 2012;129(4):e975-82.

13. Sanderson A, Hall AM, Wolfe J. Advance Care Discussions: Pediatric Clinician Preparedness and Practices. J Pain Symptom Manage. 2016;51(3):520-528.

14. Bergstraesser $E$, Inglin $S$, Abbruzzese R, Marfurt-Russenberger $K$, Hošek $M$, Hornung R. The needs of professionals in the palliative care of children and adolescents. Eur J Pediatr. 2013;172(1):111118.

15. Heckford E, Beringer AJ. Advance Care Planning: Challenges and Approaches for Pediatricians. J Palliat Med. 2014;17(9):1049-1053. 
16. Braun V, Clarke V. Using thematic analysis in psychology. Qual Res Psychol. 2006;3(2):77-101.

17. Thomas DR. A General Inductive Approach for Analyzing Qualitative Evaluation Data. Am J Eval. 2006;27(2):237-246.

18. Casterle BD De, Gastmans C, Bryon E, Denier Y. QUAGOL: A guide for qualitative data analysis. Int J Nurs Stud. 2012; 49: 360-371.

19. Tong A, Sainsbury P, Craig J. Consolidated criteria for reporting qualitative research ( COREQ ): a 32-item checklist for interviews and focus groups. Int J Qual Heal Care. 2007;19(6):349-357.

20. Kvale S. InterViews: An Introduction to Qualitative Research Interviewing. Thousand Oaks, California: SAGE publications; 1996.

21. Hennink MM, Kaiser BN, Marconi VC. Code Saturation Versus Meaning Saturation: How Many Interviews Are Enough? Qual Health Res 27(4):591-608

22. Donovan HS, Ward SE, Song MK, Heidrich SM, Gunnarsdottir S, Phillips CM. An update on the representational approach to patient education. J Nurs Scholarsh. 2007;39(3):259-265.

23. Briggs L. Shifting the Focus of Advance Care Planning: Using an In-depth Interview to Build and Strengthen Relationships. J Palliat Med. 2004;7(2):341-349.

24. Fahner JC, Beunders AJM, Heide A Van Der, et al. Interventions Guiding Advance Care Planning Conversations: A Systematic Review. J Am Med Dir Assoc. 2019;20(3):227-248.

25. Verberne LM, Kars MC, Schouten-van Meeteren AYN, et al. Aims and tasks in parental caregiving for children receiving palliative care at home: a qualitative study. Eur J Pediatr. 2017;176(3):343354.

26. Verberne LM, Kars MC, Schouten-van Meeteren AYN, et al. Parental experiences and coping strategies when caring for a child receiving paediatric palliative care: a qualitative study. Eur J Pediatr 2019;178:1075-1085

27. Sudore RL, Lum HD, You JJ, et al. Defining Advance Care Planning for Adults: A Consensus Definition From a Multidisciplinary Delphi Panel. J Pain Symptom Manage. 2017;53(5):821-832.e1.

28. Waldman E, Wolfe J. Palliative care for children with cancer. Nat Rev Clin Oncol. 2013;10(2):86-93.

29. Gilissen J, Pivodic L, Smets T, et al. Preconditions for successful advance care planning in nursing homes: A systematic review. Int J Nurs Stud. 2017;66:47-59.

30. Fahner JC, Rietjens JAC, van der Heide A, van Delden JJM, Kars MC. Survey of paediatricians caring for children with life-limiting conditions found that they were involved in advance care planning. Acta Paediatr. 2019;00(July):1-8.

\section{Appendices}

Topic lists Developmental phase 
Chapter 6

Evaluation showed that stakeholders valued the support provided by the Implementing Pediatric Advance Care Planning Toolkit

\author{
Jurrianne C. Fahner \\ Judith A.C. Rietjens \\ Agnes van der Heide \\ Megan M. Milota \\ Johannes J.M. van Delden \\ Marijke C. Kars
}

Acta Paediatr. 2020 May 20. doi: 10.1111/apa.15370. Online ahead of print. 


\section{Abstract}

Aim: This study described the development, and pilot evaluation, of the Implementing Pediatric Advance Care Planning Toolkit (IMPACT).

Methods: Key elements of pediatric advance care planning (ACP) were defined using a systematic review, a survey of 168 pediatricians and qualitative studies of 13 children with life-limiting conditions, 20 parents and 18 pediatricians. Participants were purposively recruited from six Dutch university hospitals during September 2016 and November 2018. Key elements were translated into intervention components guided by theory. The acceptability of the content was evaluated by a qualitative pilot study during February and September 2019. This focused on 27 children with life-limiting conditions from hospitals, a hospice and home care, together with 41 parents, 11 physicians and seven nurses who cared for them.

Results: IMPACT provided a holistic, caring approach to ACP, gave children a voice and cared for their parents. It provided information on ACP for families and clinicians, manuals to structure ACP conversations and training for clinicians in communication skills and supportive attitudes. The 53 pilot study participants felt that IMPACT was appropriate for pediatric ACP.

Conclusion: IMPACT was an appropriate intervention that supported a holistic approach towards pediatric $A C P$, focused on the child's perspective and provided care for their parents. 


\section{Introduction}

The number of children and adolescents living with life-limiting conditions has increased due to medical and technological advances. ${ }^{1}$ These are conditions where there are no curative treatment options left or where a cure might be possible, but could still lead to a premature death. ${ }^{1}$ The importance of communicating with children and their parents about care options is widely acknowledged. Advance care planning (ACP) is a valuable communications strategy that aligns future medical care with individual values and preferences, in a timely manner, before the end of life. ${ }^{2}$

Although medical associations have emphasized the importance of ACP for children with lifelimiting conditions, standard ACP approaches in pediatrics have been scarce., Evidence suggests that families and clinicians value the concept of ACP, even earlier in disease trajectories than is normal practice. 5 However, more than $70 \%$ of pediatric clinicians reported ACP discussions happened infrequently and too late. ${ }^{6,7}$ Barriers to ACP in pediatrics have included the fear of causing emotional distress in families and difficulties identifying the right time to start. ${ }^{6-8}$

A growing number of programs that support the implementation of ACP have been reported in palliative care. ${ }^{4}$ These interventions have mainly focused on adults and might need adjustment for use in pediatrics. This is because of: the stage of the child's development, the involvement of the parents, the diverse disease trajectories and the specific needs of pediatric end-of-life care. In addition, existing ACP programs often consist of complex interventions with multiple, interacting, components. This makes adapting for a pediatric setting difficult. Furthermore, detailed descriptions of these complex interventions are lacking in the literature, hindering their use in other contexts. ${ }^{9}$

The few ACP interventions that have been adapted for use in pediatrics focus mainly on specific patient populations. These include adolescents and young adults with cancer and patients living with acquired immune deficiency syndrome. ${ }^{10-12}$ The focus of these studies, on the patients and their end-of-life preferences, might hinder both their earlier use in disease trajectories and their use with younger children and their parents. In addition to evidence-based approaches, there 
are also practice-based initiatives funded by governments or healthcare institutions. ${ }^{13}$ However, the evidence and rationale for these programs is often unclear, limiting their use in the research and development of ACP. A comprehensive, evidence-based intervention to facilitate ACP for children with life-limiting conditions, and their families, both early and later in disease trajectories, has been lacking. Therefore, the Implementing Pediatric Advance Care Planning Toolkit (IMPACT) research project was initiated to facilitate ACP for children with life-limiting conditions and their families, starting shortly after diagnosis and continuing until the end of life. The aims of this study were to describe the developmental process and content of IMPACT so that users could understand the rationale of the intervention and report first impressions of stakeholders using IMPACT.

\section{Methods}

\section{Study design}

The Framework for the Development and Evaluation of Complex Interventions, which was designed by the Medical Research Council, was used to structure the study design in five steps (Table 1). ${ }^{14}$ These steps integrated evidence from literature, consultation with 28 international experts in pediatric palliative care and the findings from sub-studies performed by the research team within this project. The sub-studies included a systematic review of interventions which guided ACP conversations ${ }^{15}$ and a cross-sectional survey of pediatricians' experiences with ACP. ${ }^{6}$ They also carried out qualitative interviews with parents ${ }^{16}$, children, and clinicians about their perspectives of ACP. The findings from these sub-studies were considered in relation to existing theoretical concepts. This resulted in a tentative model for pediatric ACP and a logic model for the intervention. ${ }^{17}$ This showed how the components of the intervention linked to underlying theories and anticipated outcomes. Subsequently, these insights were translated into the specific content of IMPACT. A prototype consisting of all the intervention materials was discussed with a multidisciplinary team of 12 experts, comprising clinicians, researchers and representatives from patients' associations. The intervention was adjusted by linguistic experts and read by the family of a seriously ill child to make sure it was clear. Lastly, the acceptability of the content of the 
intervention was evaluated with stakeholders as part of a larger qualitative study about the early experiences with IMPACT.

\section{Table 1. Overview of the steps in the developmental and pilot phase}

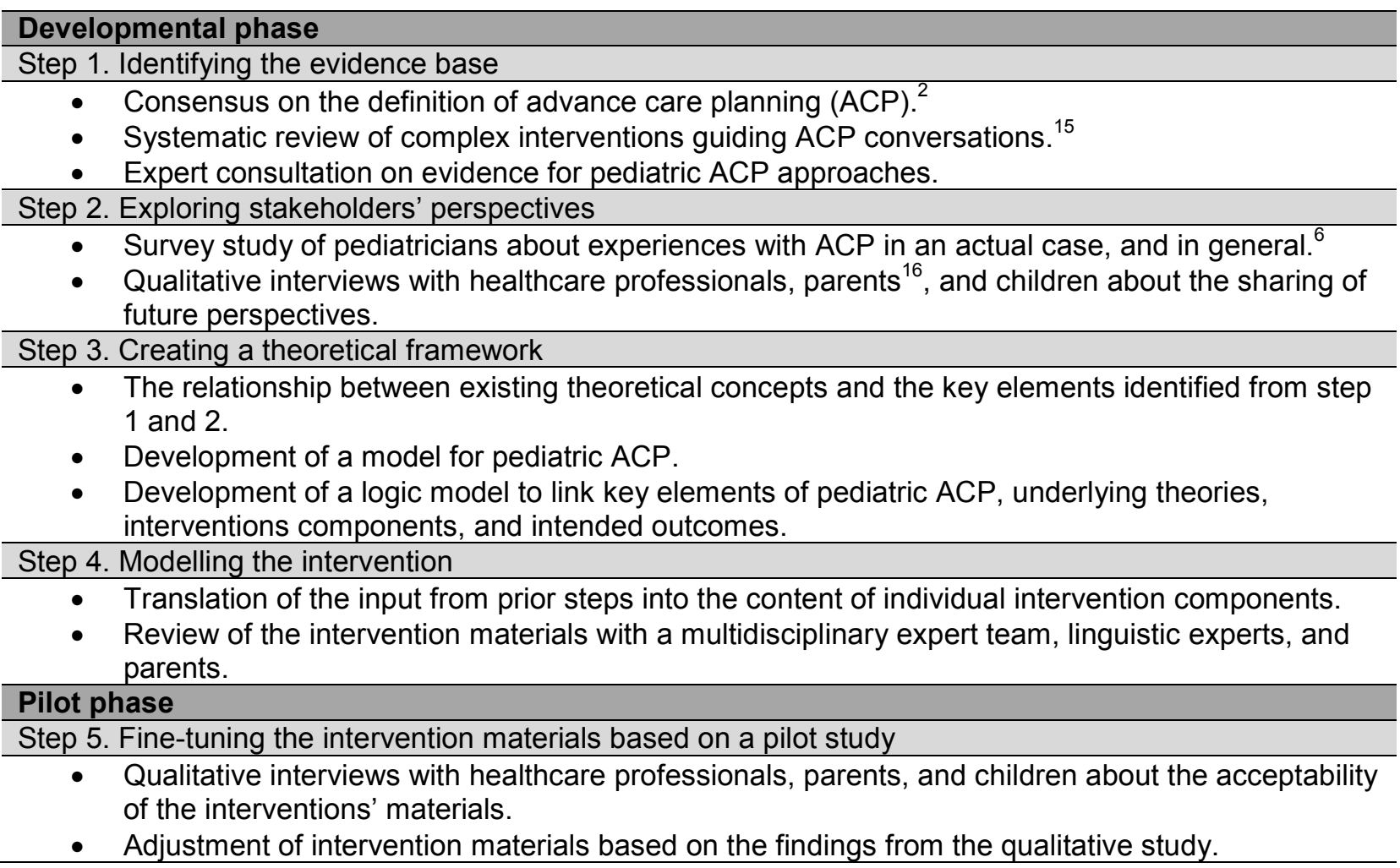

\section{Study population}

This study focused on Dutch-speaking children with life-limiting conditions under the age of 18 , their parents, and clinicians. Participants in the sub-studies of the developmental phase were purposefully recruited from six pediatric university hospitals during September 2016 and November 2018. The survey comprised 168 pediatricians, caring for children with life-limiting conditions. ${ }^{6}$ Individual interviews were conducted with 18 pediatricians caring for children with life-limiting conditions in order to gain a deeper insight into their perspectives of ACP. A qualitative interview study analyzed the perspectives on ACP of 20 parents of children with lifelimiting conditions, including 10 bereaved parents. ${ }^{16}$ The perspectives that IMPACT provided on children living with a life-limiting condition were explored at the start of the pilot study. The 
children had diverse medical backgrounds and were aged 11 to 18 years. Two children were siblings of a child with a life-limiting condition. Of the 13 children, 11 participated in focus group interviews and two children participated in individual interviews. Table 2 provides an overview of the participant characteristics.

The pilot study participants were purposefully recruited from pediatric university hospitals, a hospice and a home care, during February and September 2019. The IMPACT training was attended by 11 physicians and seven nurses, experienced in the care for children with lifelimiting conditions. Subsequently, these clinicians invited the parents of children with lifelimiting conditions to participate in the study. Some of the children were invited to participate, depending on their age and mental state. The study comprised 25 children with life-limiting conditions, aged six months to 18 years and two patients who reached adulthood, but were still receiving pediatric care due to severe cognitive impairment and grow retardation. The pilot study comprised 26 mothers, 15 fathers and five children. Table 3 provides an overview of the participants' characteristics.

The research ethics committee of the University Medical Center Utrecht decided that the qualitative studies in the developmental phase and pilot phase were exempt from review under the Medical Research Involving Humans Act (27 September 2017, reference number 17-662/C, and 14 November 2018, reference number 18-770/C). All participants provided written, informed consent.

\section{Data collection and analysis}

The data collection and analysis yielded several strategies due to the study design, including different sub-studies. The survey study was based on an online questionnaire and descriptive statistics were reported. ${ }^{6}$ The qualitative studies of the development, and the pilot phase, were based on individual or focus group interviews. These interviews were audio recorded and transcribed verbatim. A thematic analysis was performed. The results of the sub-studies were presented as narrative summaries that followed the five steps of the study design (Table 1$){ }^{18}$ 
Table 2. Characteristics of healthcare professionals, parents, and children in the developmental phase.

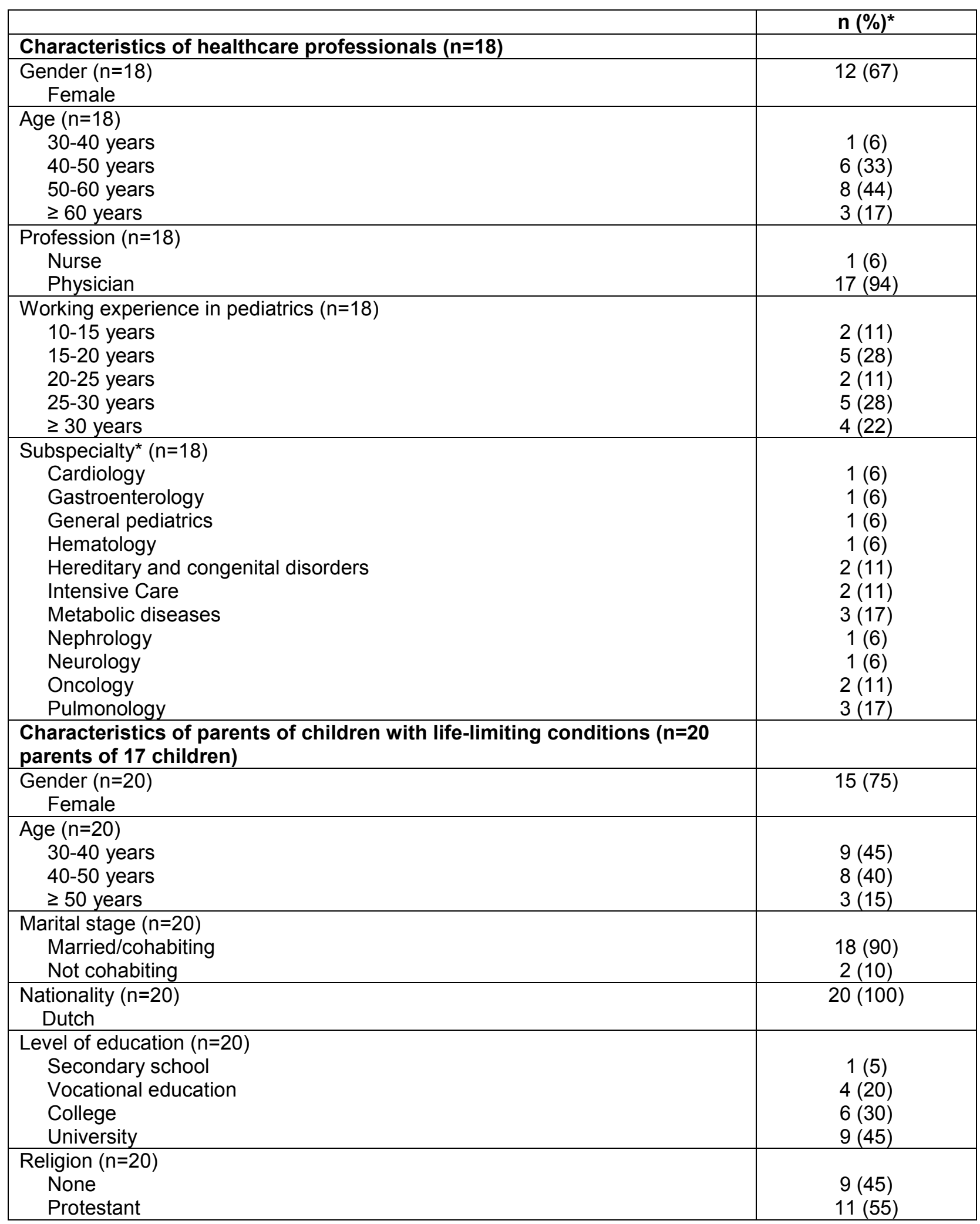




\begin{tabular}{|c|c|}
\hline $\begin{array}{l}\text { Gender of child with life-limiting condition }(n=17) \\
\text { Female }\end{array}$ & $5(29)$ \\
\hline $\begin{array}{l}\text { Children who died due to serious illness }(n=17) \\
\text { Total }\end{array}$ & $6(35)$ \\
\hline $\begin{array}{l}\text { Age of the child at death/at interview }(n=17) \\
<1 \text { year } \\
1-5 \text { years } \\
5-12 \text { years } \\
>12 \text { years }\end{array}$ & $\begin{array}{l}3(18) \\
6(35) \\
5(29) \\
3(18)\end{array}$ \\
\hline $\begin{array}{l}\text { Diagnosis of the child }(n=17) \\
\text { Chromosomal anomaly } \\
\text { Congenital heart disease } \\
\text { CNS tumor } \\
\text { Cystic Fibrosis } \\
\text { Neuromuscular disease } \\
\text { Epilepsy syndrome } \\
\text { Perinatal asphyxia }\end{array}$ & $\begin{array}{l}7(41) \\
4(24) \\
2(12) \\
1(6) \\
1(6) \\
1(6) \\
1(6)\end{array}$ \\
\hline $\begin{array}{l}\text { Child's age at diagnosis }(n=17) \\
<1 \text { year } \\
1-5 \text { years } \\
>5 \text { years }\end{array}$ & $\begin{array}{l}12(71) \\
3(18) \\
2(12)\end{array}$ \\
\hline Characteristics of children with life-limiting cc & \\
\hline $\begin{array}{l}\text { Gender }(n=13) \\
\text { Female }\end{array}$ & $8(62)$ \\
\hline $\begin{array}{l}\text { Age at interview }(n=13) \\
10-12 \text { years } \\
12-14 \text { years } \\
14-16 \text { years } \\
16-18 \text { years } \\
\geq 18 \text { years }\end{array}$ & $\begin{array}{l}1(8) \\
2(15) \\
4(31) \\
3(23) \\
3(23)\end{array}$ \\
\hline $\begin{array}{l}\text { Level of education }(n=13) \\
\text { Primary school } \\
\text { Secondary school } \\
\text { Vocational education } \\
\text { University } \\
\end{array}$ & $\begin{aligned} & 1(8) \\
& 10(77) \\
& 1(8) \\
& 1(8) \\
&\end{aligned}$ \\
\hline $\begin{array}{l}\text { Nationality }(n=13) \\
\text { Dutch }\end{array}$ & $13(100)$ \\
\hline $\begin{array}{l}\text { Religion }(n=13) \\
\text { Protestant } \\
\text { None }\end{array}$ & $\begin{array}{c}2(15) \\
11(85)\end{array}$ \\
\hline $\begin{array}{l}\text { Diagnosis }(\mathrm{n}=11) \\
\text { Auto-immune disorder } \\
\text { Congenital heart disease } \\
\text { Hematologic disease } \\
\text { Metabolic disease } \\
\text { Neuroendocrine disease } \\
\text { Pulmonary disease } \\
\text { Renal disease }\end{array}$ & $\begin{array}{c}1(9) \\
1(9) \\
2(18) \\
1(9) \\
3(27) \\
2(18) \\
1(9)\end{array}$ \\
\hline $\begin{array}{l}\text { Child's age at diagnosis }(n=11) \\
<1 \text { year } \\
1-5 \text { years } \\
\geq 5 \text { years }\end{array}$ & $\begin{array}{l}6(55) \\
1(9) \\
4(36)\end{array}$ \\
\hline
\end{tabular}


Table 3. Characteristics of healthcare professionals, parents, and children in the pilot phase

\begin{tabular}{|c|c|}
\hline \multirow{2}{*}{ Characteristics of healthcare professionals $(n=18)$} & n (\%) \\
\hline & \\
\hline $\begin{array}{l}\text { Gender }(n=18) \\
\quad \text { Female }\end{array}$ & $18(100)$ \\
\hline $\begin{array}{c}\text { Age }(n=18) \\
40-50 \text { years } \\
50-60 \text { years } \\
\geq 60 \text { years }\end{array}$ & $\begin{array}{l}12(67) \\
3(17) \\
3(17)\end{array}$ \\
\hline $\begin{array}{l}\text { Profession }(\mathrm{n}=18) \\
\text { Nurse } \\
\text { Physician }\end{array}$ & $\begin{array}{l}7(39) \\
11(61)\end{array}$ \\
\hline $\begin{array}{l}\text { Working experiences in pediatrics }(n=18) \\
5-10 \text { years } \\
10-15 \text { years } \\
15-20 \text { years } \\
20-25 \text { years } \\
25-30 \text { years } \\
\geq 30 \text { years }\end{array}$ & $\begin{array}{l}2(11) \\
2(11) \\
5(28) \\
3(17) \\
2(11) \\
4(22)\end{array}$ \\
\hline $\begin{array}{l}\text { Subspecialty }(\mathrm{n}=18) \\
\text { General practitioner in pediatric hospice } \\
\text { Home care } \\
\text { Hospice care } \\
\text { Intensive Care } \\
\text { Neurology } \\
\text { Oncology } \\
\text { Palliative Care } \\
\text { Profound Intellectual and multiple disabilities }\end{array}$ & $\begin{array}{l}1(6) \\
2(11) \\
1(6) \\
3(17) \\
2(11) \\
1(6) \\
3(17) \\
1(6)\end{array}$ \\
\hline Characteristics of parents $(n=41)$ & \\
\hline $\begin{array}{l}\text { Parents participating in ACP conversation }(n=41) \\
\text { Female }\end{array}$ & $26(63)$ \\
\hline $\begin{array}{l}\text { Parents interviewed after ACP conversation }(n=32) \\
\quad \text { Female }\end{array}$ & $24(75)$ \\
\hline $\begin{array}{l}\text { Age }(n=32) \\
\quad \leq 29 \text { years } \\
30-40 \text { years } \\
40-50 \text { years } \\
\geq 50 \text { years }\end{array}$ & $\begin{array}{c}4(13) \\
5(16) \\
16(50) \\
7(22)\end{array}$ \\
\hline $\begin{array}{l}\text { Marital stage }(\mathrm{n}=41) \\
\text { Married/cohabiting } \\
\text { Not cohabiting }\end{array}$ & $\begin{array}{c}38(93) \\
3(73)\end{array}$ \\
\hline $\begin{array}{l}\text { Nationality }(n=41) \\
\text { Dutch } \\
\text { Other }\end{array}$ & $\begin{array}{c}40(98) \\
1(2)\end{array}$ \\
\hline $\begin{array}{l}\text { Level of education }(n=32) \\
\text { Secondary school } \\
\text { Vocational education } \\
\text { College } \\
\text { University }\end{array}$ & $\begin{array}{c}10(31) \\
8(25) \\
10(31) \\
4(13) \\
\end{array}$ \\
\hline $\begin{array}{l}\text { Religion }(n=40) \\
\text { None } \\
\text { Roman Catholic }\end{array}$ & $\begin{array}{l}14(35) \\
7(18)\end{array}$ \\
\hline
\end{tabular}




\begin{tabular}{|c|c|}
\hline $\begin{array}{l}\text { Protestant } \\
\text { Islam } \\
\text { Jewish } \\
\text { Other }\end{array}$ & $\begin{array}{l}6(15) \\
4(10) \\
1(3) \\
1(3)\end{array}$ \\
\hline Characteristics of children $(n=27)$ & \\
\hline $\begin{array}{l}\text { Gender }(n=27) \\
\text { Female }\end{array}$ & $16(59)$ \\
\hline $\begin{array}{l}\text { Age at participation pilot study }(\mathrm{n}=27) \\
0-5 \text { years } \\
5-10 \text { years } \\
10-15 \text { years } \\
15-18 \text { years } \\
\geq 18 \text { years }\end{array}$ & $\begin{array}{l}7(26) \\
5(19) \\
6(22) \\
6(22) \\
3(11)\end{array}$ \\
\hline $\begin{array}{l}\text { Diagnosis }(\mathrm{n}=27) \\
\text { Congenital brain disorder } \\
\text { Congenital heart disease } \\
\text { Epilepsy syndrome } \\
\text { Gastrointestinal disorder } \\
\text { Genetic disorder } \\
\text { Metabolic disease } \\
\text { Neuromuscular disease } \\
\text { Oncology } \\
\text { Unknown } \\
\end{array}$ & $\begin{array}{l}2(7) \\
1(4) \\
3(11) \\
1(4) \\
6(22) \\
6(22) \\
6(22) \\
1(4) \\
1(4)\end{array}$ \\
\hline $\begin{array}{l}\text { Child's age at diagnosis }(n=24) \\
<1 \text { year } \\
1-5 \text { years } \\
\geq 5 \text { years }\end{array}$ & $\begin{array}{c}9(38) \\
11(46) \\
4(17)\end{array}$ \\
\hline $\begin{array}{l}\text { Siblings }(n=27) \\
\quad \text { None } \\
1 \\
2 \\
>2 \\
\end{array}$ & $\begin{array}{c}4(15) \\
8(30) \\
12(44) \\
3(11) \\
\end{array}$ \\
\hline $\begin{array}{l}\text { Children participating in... }(\mathrm{n}=27) \\
\text { ACP conversation } \\
\text { Interview after ACP conversation } \\
\text { None of the above }\end{array}$ & $\begin{array}{c}5(19) \\
3(11) \\
22(81) \\
\end{array}$ \\
\hline
\end{tabular}




\section{Results}

Step one: the evidence on key pediatric ACP elements

Since a specific definition of ACP in pediatrics was lacking, the European Association for Palliative Care definition was used to formulate the basic key elements. ${ }^{2}$ It was seen as a communication process to enable patients to define their preferences and goals for care. It also enabled them to discuss these preferences with their families and the healthcare professionals caring for them and to document, and review these, if appropriate. Although this international definition focused on competent adults, the key elements of ACP that was proposed by this definition were applicable in pediatrics as well. The systematic review of interventions to support ACP conversation, revealed four phases: preparation, initiation, exploration and action. ${ }^{15}$ A list of the topics to be addressed in each phase was extracted. These included: living with illness, living a good life, preferences for care and treatment, perspectives on the end of life and attitudes to decision-making. ${ }^{15}$ Topics specific to pediatric ACP were added after consulting experts. These included the child's identity, parenting and family life. ${ }^{19-23}$ Both the findings from the systematic review ${ }^{15}$ and expert consultation emphasized the need for clinician training in communication strategies in order to use any ACP conversation guide adequately. Table 4 illustrates the potential for intervention using elements of pediatric ACP derived from the current evidence. 


\section{Table 4. The key elements identified and the potential intervention building blocks as derived from current evidence and stakeholders' perspectives.}

\begin{tabular}{|c|c|}
\hline Identified key elements & Potential intervention building blocks \\
\hline \multicolumn{2}{|l|}{ Step 1. Identifying the evidence base } \\
\hline $\begin{array}{l}\text { ACP is defined as a process to } \\
\text { discover, discuss and document } \\
\text { preferences and goals for future } \\
\text { care. }^{2}\end{array}$ & $\begin{array}{l}\text { - Materials to support individuals to identify their } \\
\text { preferences, values and goals. } \\
\text { - Materials to help individuals to share preferences and } \\
\text { goals with family and clinicians. } \\
\text { Materials to support documentation of the preferences } \\
\text { and goals to be able to review them over time. }\end{array}$ \\
\hline $\begin{array}{l}\text { A framework for ACP conversations } \\
\text { consists of preparation, initiation, } \\
\text { exploration and action. }\end{array}$ & $\begin{array}{l}\text { Materials to prepare for ACP conversations. } \\
\text { - A conversation guide that structures ACP } \\
\text { conversations according to the framework. }\end{array}$ \\
\hline $\begin{array}{l}\text { In ACP, exploring the perspectives of } \\
\text { the child and family on living with } \\
\text { illness and living a good life is } \\
\text { essential - expert consultation. }{ }^{15}\end{array}$ & $\begin{array}{l}\text { - Conversation guide that stimulates exploring topics } \\
\text { relevant to living with illness and living a good life. }\end{array}$ \\
\hline $\begin{array}{l}\text { Communication training is needed to } \\
\text { implement ACP adequately - expert } \\
\text { consultation. }\end{array}$ & $\begin{array}{l}\text { - Communication training for healthcare professionals } \\
\text { that supports them to conduct ACP adequately. }\end{array}$ \\
\hline \multicolumn{2}{|c|}{ Step 2. Exploring stakeholders' perspectives } \\
\hline $\begin{array}{l}\text { Education on the holistic approach of } \\
\text { ACP is needed. }{ }^{2,16}\end{array}$ & $\begin{array}{l}\text { Materials to educate stakeholders about the concept } \\
\text { of ACP. } \\
\text { - Conversation guide that stimulates exploration of the } \\
\text { medical, psychological, social, and spiritual domain. }\end{array}$ \\
\hline $\begin{array}{l}\text { Attention to the voice of the child is } \\
\text { needed in ACP. } 2,6,16\end{array}$ & $\begin{array}{l}\text { - Separate preparation leaflet for children. } \\
\text { - Separate questions for children in conversation guide. } \\
\text { - Training for healthcare professionals to explore the } \\
\text { voice of the child. }\end{array}$ \\
\hline $\begin{array}{l}\text { An attitude of caring is needed in } \\
\text { ACP. }{ }^{16}\end{array}$ & $\begin{array}{l}\text { The conversation guide stimulates exploring parental } \\
\text { perspectives on the burden of care, parenting role, } \\
\text { their expertise and the child's identity. } \\
\text { Involvement of a healthcare professional in taking } \\
\text { care of the child instead of an external facilitator. } \\
\text { Communication training for healthcare professionals } \\
\text { to respond to emotions, create an attitude of listening } \\
\text { and deliver medical expertise in an appropriate way. }\end{array}$ \\
\hline
\end{tabular}

Step two: key pediatric ACP elements from the stakeholders' perspectives

The survey study evaluated the stakeholders' views of ACP from the perspective of paediatricians. ${ }^{6}$ These, together with the qualitative research of the parents of children with lifelimiting conditions ${ }^{16}$, the children themselves and the clinicians who cared for children with lifelimiting conditions, revealed three additional key elements for pediatric ACP (Table 4). 
Firstly, education is required about the holistic nature of ACP. The sub-studies showed that pediatricians talk about medical themes relating to ACP rather than exploring individual family values. ${ }^{6}$ Parents wanted pediatricians to explore what their lives were like from a psychological, social and spiritual point of view. ${ }^{16}$

Secondly, the pediatricians, parents and children all emphasized the importance of the child's perspective. ${ }^{16}$ However, the pediatricians who took part in the qualitative interviews reported challenging experiences when trying to approach children and communicate adequately with them. Parents saw themselves as the best advocates for their child, yet they struggled to define their child's best interests. ${ }^{16}$ Strategies to elicit the voice of the child are needed, either through direct communication with the child or by trying to understand the child's perspective.

Thirdly, during the qualitative studies, both the pediatricians and parents expressed the need for a caring attitude when sharing future perspectives. Pediatricians needed to feel confident asking families about sensitive themes. Parents needed genuine attention for their challenging situation. They also stated that their pediatrician's acknowledgement of their child as an individual, and their tasks and expertise as parents, would be a precondition for sharing their deepest thoughts regarding their child's future. ${ }^{16}$

\section{Step three: a theoretical framework}

Few of the ACP interventions evaluated by our systematic review relied on a clear theoretical background. ${ }^{15}$ Behavioral theories were most commonly used as underlying concepts. ${ }^{15}$ The representational approach of patient education explains how exploring patients' perspectives, and tailoring information to them, leads to highly patient-specific processes. ${ }^{24}$ This supported the finding that IMPACT should explore the child's and family's experiences and perspectives regarding the future. It should also guide professionals on when, and how, to provide the family with tailored information during a conversation. Behavioral change theory helps us to understand that the attitudes of both families and clinicians regarding ACP can entail different stages of change, which may influence their level of engagement. ${ }^{25}$ 
Steps one and two demonstrated the need for a holistic approach and for attention to be paid to the challenges facing families. Therefore, theories about parental coping when caring for a child with a life-limiting condition were used to give insight into the needs of this specific population. The dual process of coping with bereavement theory shows that elements that focus on both loss and restoration are needed to cope with loss. ${ }^{26,27}$ This theory can be helpful in designing interventions that support a caring attitude and include conversation topics that focus on joy and hopes, as well as on fears, worries and worst case scenarios.

Research into the role of prognostic disclosure indicates that providing such information with sensitivity and realism makes the parent-clinician relationship a source of hope and can help parents endure difficult medical scenarios. ${ }^{28}$ Therefore, intervention components need to encourage parents and clinicians to address expectations for the future and explore perspectives on worst case scenarios.

Concepts about parenting roles provided a theoretical foundation for understanding that parents need to feel acknowledged in their challenging role regarding their seriously ill child. ${ }^{20,23}$ Parents aim to control symptoms and disease, create a life worth living for their child and maintain family balance. These aims may, in turn, inform parents' values and preferences for care and treatment and should therefore be explored in conversations about future care. ${ }^{20}$

The aforementioned theories all relate to the overarching conceptual model of person-centered care. Here, the patient has an active, central role in decision-making and organizing their healthcare with clinicians, and, ultimately, this helps the patient lead a meaningful life. ${ }^{29}$ ACP can support this person-centered care.

These concepts are reflected in a model for pediatric $A C P$, which aims to combine the lived experiences and expertise of children and their families with the expertise of the healthcare team (Figure 1). Through mutual identification and sharing perspectives, shared care goals can be achieved and, when appropriate, treatment decisions aligned to provide high-quality, personcentered care from diagnosis to the end of life. 
The logic model illustrates how the key elements identified in steps one and two are linked to the underlying theories described in step three (Figure 2).

\section{Figure 1. Model of pediatric advance care planning}

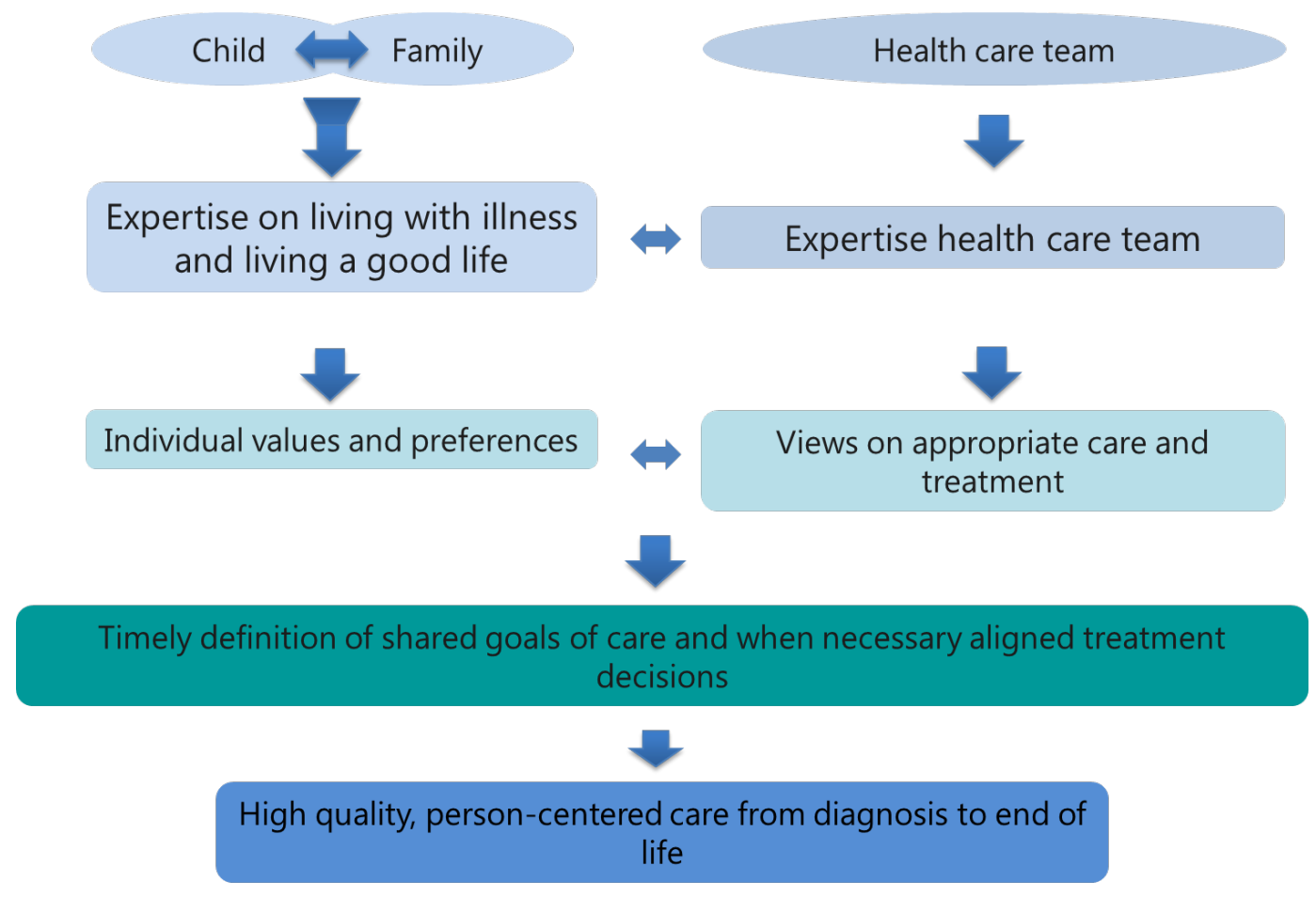


Figure 2. Logic model of IMPACT

\begin{tabular}{|c|c|c|c|c|}
\hline CONTEXT & THEORETICAL BACKGROUND & INTERVENTION & MECHANISM OF ACTION & OUTCOME \\
\hline $\begin{array}{l}\text { Setting: } \\
\text { ACP for children } \\
\text { with life-limiting } \\
\text { conditions and their } \\
\text { families } \\
\text { Concept ACP: } \\
\text { Bringing together } \\
\text { expertise } \\
\text { child/family and } \\
\text { medical expertise } \\
\text { by discovering, } \\
\text { discussing and } \\
\text { documenting } \\
\text { shared goals of } \\
\text { future care and } \\
\text { aligned treatment } \\
\text { decisions } \\
\text { Aim ACP: } \\
\text { Align future medical } \\
\text { care with individual } \\
\text { values and } \\
\text { preferences } \\
\text { Providers: HCPs } \\
\text { involved in the care } \\
\text { for these childeren } \\
\text { Areas of attention: } \\
- \text { Holistic } \\
\text { approach } \\
\text { - Voice of the } \\
\text { child } \\
\text { - Attitude of } \\
\text { caring }\end{array}$ & $\begin{array}{l}\text { Concept of care theories } \\
\text { Person-centered-care: } \\
\text { The patient has a central and active } \\
\text { role as a person in decision making } \\
\text { and organizing health care, aiming } \\
\text { to create a meaningful lifere }\end{array}$ & $\begin{array}{l}\text { 'Discover' } \\
\text {. Leaflet children to } \\
\text { prepare for the ACP } \\
\text { conversation } \\
\text { - Leaflet parents to } \\
\text { prepare for the ACP } \\
\text { conversation } \\
\text { - Brochure HCPs to } \\
\text { educate about the } \\
\text { concept of ACP } \\
\text { - Preparation card HCPs } \\
\text { to structure the } \\
\text { invitation of families } \\
\text { and create } \\
\text { appropriate } \\
\text { circumstances } \\
\\
\text { 'Discuss' } \\
\text { - Conversation guide } \\
\text { for conversations with } \\
\text { parents } \\
\text { - Conversation guide } \\
\text { for conversation with } \\
\text { children and parents } \\
\text { - Training of specific } \\
\text { communication skills: } \\
\text { explore values, } \\
\text { respond to emotions, } \\
\text { respond to stage of } \\
\text { change, provide } \\
\text { information, make } \\
\text { recommendations } \\
\text { - Pocket guide } \\
\text { 'Document' } \\
\text { - Format for reporting } \\
\text { the ACP conversation }\end{array}$ & $\begin{array}{l}\text { Knowledge } \\
\text { - Leaflet for children and } \\
\text { parents helps them to } \\
\text { understand the concept of } \\
\text { ACP and to prepare for the } \\
\text { conversation. They can fill } \\
\text { out their own booklet, bring } \\
\text { it to the conversation and } \\
\text { share their perspective } \\
\text { - Brochure for HCPs educates } \\
\text { them about the concept of } \\
\text { ACP and strategies how to } \\
\text { implement ACP in their } \\
\text { practice } \\
\text { Skills } \\
\text { Communication training } \\
\text { improves communication } \\
\text { skills of HCPs } \\
\text { Verbal examples help HCPs } \\
\text { to use the right words and } \\
\text { reduce their insecurity } \\
\text { Guidance } \\
\text { The preparation card and } \\
\text { conversation guide help } \\
\text { HCPs to pay attention to } \\
\text { domains beyond the } \\
\text { medical domain and the life } \\
\text { world of families. They } \\
\text { stimulate exploration of } \\
\text { family's perspectives and } \\
\text { guide HCPs when to bring } \\
\text { in their medical expertise } \\
\text { A format structures } \\
\text { documentation of the } \\
\text { conversation. It stimulates } \\
\text { reflection afterwards and } \\
\text { initiates follow-up } \\
\text { conversations } \\
\text { - }\end{array}$ & $\begin{array}{l}\text { - Increased prevalence of } \\
\text { discussions about } \\
\text { individual values and } \\
\text { preferences for future } \\
\text { care and treatment } \\
\text { - Increased knowledge } \\
\text { about the holistic } \\
\text { approach of ACP } \\
\text { - Increased attention to } \\
\text { the perspectives of the } \\
\text { child itself } \\
\text { - Increased attention to } \\
\text { the parenting role, way } \\
\text { of coping and situation } \\
\text { of the family } \\
\text { - Increased structured } \\
\text { documentation of ACP } \\
\text { conversations }\end{array}$ \\
\hline
\end{tabular}


Step four: the intervention design

Specific intervention components and their intended outcomes were defined according to the logic model (Figure 2). The intervention components are described in Table $5 .^{30}$ These consist of a toolkit for clinicians and families and training for clinicians. The toolkit includes information leaflets about the concept of ACP in order to prepare clinicians and families for an ACP conversation. Conversation guides support the exploration of the perspectives of the child and family members related to psychological, social and spiritual domains, rather than just the physical one. The topics stimulate a conversation about the perspectives of the child, and parents, on living with illness, living a good life and care and treatment preferences. The preparatory materials and the conversation guide include specific questions for children as a means of involving them in the discussion. Besides the exploration of the inner perspectives of family members, an information booklet for clinicians also provides guidance on how to integrate their expertise into a conversation without undermining the family's perspectives. The conversation guide integrates individual perspectives on the care goals by a process of shared decision-making. The structure of this guide is presented as a single conversation, yet multiple conversations might be needed to discuss all the steps, especially when there are distinctive perspectives within a family or between the family and clinician.

An ACP training session was developed as part of IMPACT in collaboration with communication experts (Wilde Kastanje Training and Education, the Netherlands) (Table 6). The training focused on developing an attitude of open communication. It also taught specific ACP communication skills, such as exploring values, responding to emotions and strategies to achieve a shared point of view on care goals. ${ }^{31}$ 


\section{Table 5. Description of the characteristics of IMPACT*}

\begin{tabular}{|c|c|}
\hline Dimension & Description \\
\hline Mode & Face-to-face advance care planning (ACP) conversations \\
\hline Materials & $\begin{array}{l}\text { - Information leaflets for parents to prepare for ACP conversations. These } \\
\text { leaflets explain the concept of ACP and provide ACP questions they } \\
\text { could think about before the conversation. } \\
\text { - Information leaflet for children to prepare for the conversation. This little } \\
\text { booklet contains fill in the blank line exercises, describing what is } \\
\text { important to the child regarding living a good life, living with illness, } \\
\text { facing the future, decision-making and preferences for care and } \\
\text { treatment. } \\
\text { - Information brochure for clinicians to educate them about the ACP } \\
\text { concept and to provide recommendations for integrating ACP into their } \\
\text { daily practice. } \\
\text { - } \text { Preparation card for clinicians to invite families for an ACP conversation. } \\
\text { - Conversation guide for conversations with the child and parents to guide } \\
\text { - Conversation guide for conversations with parents. } \\
\text { - Documentation format for use by healthcare professionals, children and } \\
\text { parents. } \\
\text { Pocket guide for healthcare professionals summarizing key elements of } \\
\text { IMPACT. }\end{array}$ \\
\hline Location & At home, inpatient or outpatient department. \\
\hline Schedule & $\begin{array}{l}\text { The conversation guide is designed so that it can be used for a one-off } \\
\text { conversation or split up into multiple conversations, depending on the needs of } \\
\text { the child and family. }\end{array}$ \\
\hline Scripting & $\begin{array}{l}\text { The conversation guide structures the conversation and provides verbal } \\
\text { examples for every part of the conversation. Verbal examples need to be } \\
\text { adapted to the child's age and the family's circumstances. }\end{array}$ \\
\hline $\begin{array}{l}\text { Participants' } \\
\text { characteristics }\end{array}$ & Children living with life-limiting conditions, their parents and families. \\
\hline $\begin{array}{l}\text { Sensitivity to } \\
\text { participants' } \\
\text { characteristics }\end{array}$ & $\begin{array}{l}\text { Information leaflets are tailored to children with life-limiting conditions aged } 10 \\
\text { years and above and parents of children with life-limiting conditions of all ages. }\end{array}$ \\
\hline $\begin{array}{l}\text { Interventionist } \\
\text { characteristics }\end{array}$ & $\begin{array}{l}\text { - Healthcare professionals involved in the care of seriously ill children. } \\
\text { - A two-day training program is recommended to optimize the use of the } \\
\text { intervention. }\end{array}$ \\
\hline Adaptability & $\begin{array}{l}\text { - Language used during the conversation can be modified, based on the } \\
\text { suggested script and skills learnt in the training. } \\
\text { - The schedule of the conversation can be modified, depending upon } \\
\text { patient readiness, disease progression or specific family circumstances. }\end{array}$ \\
\hline $\begin{array}{l}\text { Treatment } \\
\text { implementation }\end{array}$ & $\begin{array}{l}\text { - At the end of the conversation, the next steps are defined. } \\
\text { - Healthcare professionals document the conversation in the medical } \\
\text { record. } \\
\text { - Children and parents receive a sheet to document the conversation for } \\
\text { their own records. }\end{array}$ \\
\hline
\end{tabular}




\section{Table 6. Description of IMPACT training}

\begin{tabular}{|c|c|}
\hline Dimension & Description \\
\hline Schedule & Two day training, four to eight weeks apart. \\
\hline Trainers & $\begin{array}{l}\text { Clinicians with expertise in the field of advance } \\
\text { care planning (ACP) and professional } \\
\text { communication trainers/actors. }\end{array}$ \\
\hline Participants & $\begin{array}{l}\text { Pediatricians, nurses, social workers, general } \\
\text { practitioners, children's life therapists. }\end{array}$ \\
\hline Preparation & Reading the materials of IMPACT \\
\hline Content day 1 & $\begin{array}{l}\text { - } \quad \text { Lecture on concept of ACP. } \\
\text { - } \quad \text { Introduction materials from IMPACT. } \\
\text { - Interactive workshop on a communication } \\
\left.\text { - } \quad \text { Roltitude (I-YOU-WE model }{ }^{*}\right) . \\
\text { conversation. } \\
\text { - Role play the exploration of the child's and } \\
\text { family's perspectives. }\end{array}$ \\
\hline Content day 2 & $\begin{array}{l}\text { - Reflection on experiences in daily } \\
\text { practice. } \\
\text { Introduction of supportive communication } \\
\text { skills, developed by VitalTalk, to set up } \\
\text { conversations about the goals of care and } \\
\text { to respond to emotions. } \\
\text { - Role play based on the conversation guide } \\
\text { with the integration of supportive } \\
\text { communication skills. }\end{array}$ \\
\hline
\end{tabular}

${ }^{*}$ The I-You-We model (Wilde Kastanje Training and Education, the Netherlands) is a conversation metaphor that supports clinicians in exploring a family's perspective (You-position), shares the clinician's own expertise (I-position), and works towards a shared goal of care (We-position). By explicitly, both verbally and non-verbally, distinguishing the family's perspectives from the clinician's perspectives, and accepting any differences in insights, it is more likely a shared care goal will be reached in an ongoing conversation (WE-position).

Step five: pilot evaluation

During the interviews with clinicians, parents and children, to evaluate their experiences with IMPACT, all groups reported appreciation of the materials and found them applicable to pediatrics as illustrated by direct quotes (Table 7). Participants perceived that all of the themes mentioned in the IMPACT materials were appropriate for discussions with children and their families. Families valued the attention for their experiences and life views beyond the medical domain. Parents reported that they would recommend the information leaflet to other parents. One mother suggested that a question could be added to the information leaflet for parents about the meaning of the serious illness to the family. Clinicians confirmed that the materials 
were useful in their daily practice, during their conversations with families and when educating their peers. Some clinicians mentioned that the exploratory phase of the conversation guide could be more succinct and these suggestions were adopted in the final version.

During the focus group interviews at the end of the developmental phase, children suggested changing the order of themes in their version of the information leaflet. They felt it inappropriate for them to talk about hopes and dreams after discussing death and dying and the order was changed as a result of their comments. Children stated that they valued questions about their hopes and dreams, even if they knew, based on their prognosis, that those wishes might never become true based on the prognosis of the disease. Therefore, the conversation guide includes questions about wishes for their later life, although clinicians need to adapt these questions to the specific context of the child. Children varied in their perspectives on the relevance of questions about death and dying. Some considered these questions relevant, while others felt that death and dying did not need to be mentioned explicitly in the leaflet. However, the questions were not removed from the leaflet. It turned out that, in the pilot phase, children were able to share their perspectives on death and dying if they wanted to. Reading the topic in the leaflet stimulated children to share their preferences about whether or not they wanted to talk about death and dying during the ACP conversation itself.

All of the final IMPACT materials are available online in Dutch and English at: www.kinderpalliatief.nl/impact 
Table 7. Illustrative quotations of perspectives on IMPACT materials of children with lifelimiting conditions, parents, and clinicians

\begin{tabular}{|c|c|}
\hline & Quotes \\
\hline \multicolumn{2}{|l|}{ Children } \\
\hline \multicolumn{2}{|l|}{ Information leaflet } \\
\hline Appropriateness & $\begin{array}{l}\text { Girl, } 13 \text { years, neuromuscular disorder } \\
\text { Yes, some children would like to know in advance what kinds of questions } \\
\text { they'll be asked so they can think about their answers. I usually come up } \\
\text { with an answer on the spot. I read the information leaflet, and I ran through } \\
\text { the questions with my mom. But ... I don't really need that [the information } \\
\text { leaflet]. } \\
\text { Boy, age } 16 \text { years, neuroendocrine disease } \\
\text { In my opinion, the information leaflet shows an interest in what a person is } \\
\text { like, instead of just the hospital stuff... Like it's more about how you feel } \\
\text { about the situation. For instance, maybe you find out someone is crazy } \\
\text { about sports and that this can cause a dilemma for that person. }\end{array}$ \\
\hline $\begin{array}{l}\text { Ambivalence } \\
\text { discussing death }\end{array}$ & $\begin{array}{l}\text { Girl, age } 15 \text { years, metabolic disease } \\
\text { I think the question [about death and dying] is really intense, but I also think } \\
\text { that if you asked a different question or tried talk around it, I would still prefer } \\
\text { that you ask it straight. I don't just want to talk about the positive stuff, } \\
\text { because I can think of that myself anyway. }\end{array}$ \\
\hline \multicolumn{2}{|l|}{ Parents } \\
\hline \multicolumn{2}{|l|}{ Information leaflet } \\
\hline Appropriateness & $\begin{array}{l}\text { Mother of a boy, age } 3 \text { years, neurologic disorder } \\
\text { I studied the leaflet; for me, these are questions that pop up every day. So } \\
\text { you briefly think about them all the time. Still, these are important topics to } \\
\text { discuss, especially with parents who find it more difficult to think about these } \\
\text { themes, and it's good to think of a strategy to broach these topics. }\end{array}$ \\
\hline Involvement child & $\begin{array}{l}\text { Mother of a girl, age } 17 \text { years, pulmonary disease } \\
\text { Well, she thought the questions were difficult to answer, but that it was okay. } \\
\text { She already prepared for these questions at home [with the leaflet]. That } \\
\text { made the conversation easier for both of us. } \\
\text { Mother of a boy, age } 12 \text { years, genetic disorder } \\
\text { We worked through the information leaflet together and wrote down all kinds } \\
\text { of stuff. When the interview started he was able to run through all the things } \\
\text { we wrote down, so that was nice. Yes, the material is appealing and the } \\
\text { questions were clear, so that was really good. Yes, he liked it, he said: now } \\
\text { l'm really important, too, eh? }\end{array}$ \\
\hline $\begin{array}{l}\text { Ambivalence } \\
\text { discussing death }\end{array}$ & $\begin{array}{l}\text { Mother of a girl, } 10 \text { years, neuromuscular disorder } \\
\text { My daughter really dislikes the topic of dying. But apart from that, I thought it } \\
\text { [the interview] was well designed. And I always tell her: You can get } \\
\text { pneumonia. Your heart can stop... That's just the inconvenient truth. We do } \\
\text { talk about it together, but she'd rather not know anything about it. } \\
\text { Mother of a boy, age } 6 \text { months, congenital heart disease } \\
\text { I thought the leaflet was clear. It makes you think differently about your } \\
\text { child. I usually don't see that I have a seriously ill child. This confronts you } \\
\text { with the facts, with the future, with his life expectancy for instance. Of course } \\
\text { you know this, but you don't... I don't want it occupying my mind at least. }\end{array}$ \\
\hline
\end{tabular}




\begin{tabular}{|c|c|}
\hline $\begin{array}{l}\text { Use of information } \\
\text { leaflet }\end{array}$ & $\begin{array}{l}\text { Mother of a girl, } 4 \text { years, metabolic disorder } \\
\text { The information leaflet structure is nice. The questions help you think about } \\
\text { how you feel about certain topics beforehand. That's why it's nice to have } \\
\text { the booklet beforehand so you know in what direction you may want to take } \\
\text { the discussion. } \\
\text { Father of a boy, age } 16 \text { years, gastro-intestinal disease } \\
\text { It was a relief for us to see there were normal questions in it, too. When } \\
\text { you're nervous about the conversation, it's comforting to see, oh yeah, it's } \\
\text { just going to be about who we are. } \\
\text { Mother of a girl, age } 8 \text { years, epilepsy syndrome } \\
\text { I think the information leaflet is suitable for situations like ours. Personally, I } \\
\text { don't think too much about these things in advance. I prefer to deal with } \\
\text { things when they cross my path. And then on to the next one. }\end{array}$ \\
\hline \multicolumn{2}{|l|}{ Conversation guide } \\
\hline $\begin{array}{l}\text { Guide stimulates to ask } \\
\text { deeper questions }\end{array}$ & $\begin{array}{l}\text { Mother of a boy, age } 6 \text { months, congenital heart disease } \\
\text { The questions worked up gradually to more difficult topics, and that was a } \\
\text { good structure. I think our clinician really needed the guidelines. Otherwise, I } \\
\text { think you could easily get off track, or feel less confident about asking } \\
\text { certain questions. I think everyone knows parents don't want to hear about } \\
\text { worst-case scenarios or life expectancy. Without the guidelines, I think she } \\
\text { might have felt more inclined to avoid certain topics. }\end{array}$ \\
\hline $\begin{array}{l}\text { Use of guide during } \\
\text { conversation }\end{array}$ & $\begin{array}{l}\text { Mother of a girl, age } 4 \text { years, metabolic disorder } \\
\text { I didn't think it was distracting. I can imagine that it's nice to have some } \\
\text { structure to the conversation. So the discussion doesn't go in all directions. I } \\
\text { think it was good for her and it didn't bother me. }\end{array}$ \\
\hline \multicolumn{2}{|r|}{ e } \\
\hline $\begin{array}{l}\text { Guide stimulates to ask } \\
\text { deeper questions }\end{array}$ & $\begin{array}{l}\text { Pediatric neurologist } \\
\text { Questions like: are you worried about the future? These are simple } \\
\text { questions. And not merely questions like: what's your day like as parents, } \\
\text { but also: how does your life look like? And when you are feeling anxious } \\
\text { about something, who do you talk to? That sort of questions we never asked } \\
\text { before. I noticed that they provide valuable information. } \\
\text { Pediatric neurologist } \\
\text { I liked the part about views on life and sources of strength. You know, it's } \\
\text { easy to skip those topics, but it's actually very important to explore them. } \\
\text { Physician pediatric hospice care } \\
\text { The structure of the guide ensures that different topics are brought up. You } \\
\text { talk gradually about death and dying, you talk about the last phase of life, } \\
\text { you discuss whether or not people have thought about these things. And } \\
\text { you talk about what is important to them. The structure of the guideline } \\
\text { helps bring these questions to light. }\end{array}$ \\
\hline $\begin{array}{l}\text { Use of guide during } \\
\text { conversation }\end{array}$ & $\begin{array}{l}\text { General pediatrician } \\
\text { During the training I thought: won't it feel unnatural to use it? But during that } \\
\text { training day I also got the feeling that it wasn't distracting at all. And I don't } \\
\text { think my cases were annoyed by it. In fact, I think they considered it diligent. } \\
\text { Pediatric palliative care nurse } \\
\text { Mostly I use the guideline to prepare myself. I read it carefully beforehand, } \\
\text { and I always bring it with me to the conversation. Like this week, I just had it }\end{array}$ \\
\hline
\end{tabular}




\begin{tabular}{|l|l|}
\hline \multicolumn{1}{|l}{} & $\begin{array}{l}\text { Iying closed in front of me on the table. I didn't need to open it, but it was } \\
\text { reassuring to have it there. } \\
\text { Pediatric palliative care nurse } \\
\text { I have tried to use the model sentences. Ultimately, I think you have to give } \\
\text { them your own twist. But the model sentences are really useful. The } \\
\text { wording is very concrete and it saves you the energy of having to think } \\
\text { about it yourself. Maybe you would pose certain questions yourself anyway, } \\
\text { but I still like the models. Plus, you can select the phrases that work best for } \\
\text { you. }\end{array}$ \\
\hline Use in education & $\begin{array}{l}\text { Physian pediatric intensive care unit } \\
\text { The topics weren't new to me, but it was nice to see them so well-structured. } \\
\text { I recently used the guideline in a course I teach, and when the website went } \\
\text { online I told all my colleagues about it. }\end{array}$ \\
\hline Information leaflet families & $\begin{array}{l}\text { General pediatrician } \\
\text { The families said [the leaflets] reflected their personal circumstances. I had } \\
\text { the impression they were very well informed about what was going to be } \\
\text { discussed. Otherwise, I can imagine that parents will constantly wonder: } \\
\text { what this doctor is getting at? This could be a distraction or could cause } \\
\text { them to feel stressed prior to the conversation, for instance, because they } \\
\text { think my intention is to discuss any treatment limitations, although that might } \\
\text { not be the case at all }\end{array}$ \\
\hline Involvement child & $\begin{array}{l}\text { Physian pediatric palliative care team } \\
\text { The patient [female, age 17] had written down her answers, not in complete } \\
\text { sentences, but with catchwords. And at the start of the conversation she } \\
\text { gave it to us, like you would an assignment. We used it to guide the } \\
\text { conversation and focus on themes that were important to her. }\end{array}$ \\
\hline
\end{tabular}




\section{Discussion}

This study describes the development and evaluation of IMPACT. This pediatric ACP intervention consists of materials to prepare clinicians, children with life-limiting conditions and their parents for advance care conversations. It also helps to guide and document them. The materials incorporate a holistic person-centered approach, stimulate the exploration of the voice of the child, and support a caring attitude during the ACP process. Clinicians and families using IMPACT found the materials helpful, applicable to their lives and practice and successful in addressing appropriate themes. Some adjustments in language and layout were made, based on the pilot study.

Our intervention differs from other pediatric ACP approaches in some aspects. Whereas most interventions are tailored to specific diseases or population age ${ }_{1}^{4}$ our intervention is intended to be used in pediatrics in general. Existing approaches have focused on preferences for end of life, yet the intention of $A C P$, according to current definitions, is to initiate ACP early in a disease trajectory. ${ }^{2}$ IMPACT is not primarily focused on the end of life and can be used at earlier phases of the disease trajectory. A strong focus on the end of life might function as a barrier to clinicians initiating ACP due the fear of distressing families and taking away hope. ${ }^{8}$ Therefore, in line with the philosophy of palliative care, IMPACT invites clinicians and families to address both views on living well in the context of a life-limiting condition, as well as views on what is important to them if death is imminent. This gradual approach leaves space for hope as well as a consideration of the future, with a realistic and appropriate understanding of the disease trajectory.

During the developmental process, we noticed that the clinician-patient relationship plays an important role in ACP, both in creating a caring attitude and guaranteeing that the preferences and care goals identified are taken into account. This might be easier when both a primary responsible clinician and the family are involved in ACP. Therefore, our clinician-based intervention differs from facilitator-based ACP approaches.

The strength of the study was the thorough developmental process. Clinicians, children with lifelimiting conditions and parents, were all involved during the entire process. This encouraged 
researchers to stay close to clinical practice and facilitated further implementation of the intervention. By exploring the perspectives of stakeholders, needs in the field could be addressed, increasing the relevance of the intervention for current daily practice. The intervention components were supported by a rationale for acting in a certain way, based on underlying theoretical concepts. This was meant to help identify essential components of the interventions and to help explain the rationale of the intervention to potential users.

A limitation of the study was that system factors were not integrated into the developmental process or the intervention. The intervention is aimed at individual clinicians and families, instead of healthcare institutions. This means that well-known barriers for ACP, such as lack of time and finances, systematic identification of eligible patients and standardized approaches for filing ACP documents in electronic medical records, were not addressed by the intervention. This might limit the implementation of the intervention in daily practice as it relies on the intrinsic motivation of individual clinicians to use it. However, the toolkit might be a good starting point for healthcare institutions to develop a standardized ACP approach. Other limitations of the study were that the stakeholders involved in the developmental process and the participants of the pilot study were mainly highly educated people with an open attitude towards ACP. This might have positively skewed their perspectives. The children included had varying diseases, prognoses and were in different stages of disease, which might result in different needs. A limitation of the study is that we could not specify the child's disease progression. That means we could not specify whether the perspectives, as presented by families, corresponded with a position early or later in a disease trajectory. We collected data about the time since diagnosis, but this did not reflect the stage of disease, its burden or length of time until end of life. We translated the perspectives of parents and children into a general approach, but it would be valuable to evaluate whether the individual needs of specific groups were sufficiently addressed by this approach or if specific groups need a more tailored approach. Currently, the intervention does not include items for children adjusted for age and development, nor does it include items that are tailored to populations with language barriers or cultural differences. Developing components to serve these populations might positively influence the broader application of the intervention. Another limitation of this study is that the qualitative pilot study, as described 
above, only evaluated experiences with the intervention materials. Ongoing research is needed to identify if the intervention contributes to the intended outcomes in daily practice and if the key elements exert their effect, as was hypothesized in the underlying theoretical concept. ${ }^{14}$

\section{Conclusion}

A theory and evidence-based pediatric ACP intervention was developed and tailored to key elements of practice. It provided support materials and clinician training about the concept of $A C P$, providing strategies on how to address the voice of the child and how to convey to a caring attitude to families throughout their child's illness. A detailed description of the developmental process and open access to all the intervention's materials will support further research and implementation in daily practice. 


\section{References}

1. Fraser ALK, Miller M, Hain R, et al. Rising National Prevalence of Life-Limiting Conditions in Children in England. Pediatrics. 2012;129(4):e923-e929.

2. Rietjens JAC, Sudore PRL, Connolly M, et al. Review Definition and recommendations for advance care planning: an international consensus supported by the European Association for Palliative Care. Lancet Oncol. 2017;18(9):e543-e551.

3. Lotz JD, Jox RJ, Borasio GD, Führer M. Pediatric advance care planning: A systematic review. Pediatrics. 2013;131(3):e873-e880.

4. Myers J, Cosby R, Gzik D, et al. Provider Tools for Advance Care Planning and Goals of Care Discussion: A Systematic Review. Am J Hosp Palliat Med. 2018;35(8):1123-1132.

5. DeCourcey DD, Silverman M, Oladunjoye A, Wolfe J. Advance Care Planning and Parent-Reported End-of-Life Outcomes in Children, Adolescents, and Young Adults With Complex Chronic Conditions. Crit Care Med. 2019;47(1):101-108.

6. Fahner JC, Rietjens JAC, van der Heide A, van Delden JJM, Kars MC. Survey of paediatricians caring for children with life-limiting conditions found that they were involved in advance care planning. Acta Paediatr Int J Paediatr. 2019;00(July):1-8.

7. Durall A, Zurakowski D, Wolfe J. Barriers to conducting advance care discussions for children with life-threatening conditions. Pediatrics. 2012;129(4):e975-e982.

8. Lotz JD, Jox RJ, Borasio GD, Fuhrer M. Pediatric advance care planning from the perspective of health care professionals: A qualitative interview study. Palliat Med. 2015;29(3):212-222.

9. Hoffmann TC, Oxman AD, Ioannidis JPA, et al. Enhancing the usability of systematic reviews by improving the consideration and description of interventions. BMJ. Published online 2017:1-8.

10. Zadeh S, Pao M, Wiener L. Opening end-of-life discussions: how to introduce Voicing My CHOiCES $^{\mathrm{TM}}$, an advance care planning guide for adolescents and young adults. Palliat Support Care. 2015;13(3):591-599. 
11. Lyon ME, Jacobs S, Briggs L, Cheng YI, Wang J. Family-centered advance care planning for teens with cancer. JAMA Pediatr. 2013;167(5):460-467.

12. Lyon ME, D'Angelo $\mathrm{L}$, Dallas $\mathrm{RH}$, et al. A randomized clinical trial of adolescents with HIV/AIDS: pediatric advance care planning. AIDS Care - Psychol Socio-Medical Asp AIDS/HIV. 2017;29(10):1287-1296.

13. CYPACP Collaboration N. Child and Young Person's Advance Care Plan. Published online 2017. http://cypacp.uk/document-downloads/. Accessed on 6 December 2019

14. Craig P, Dieppe P, Macintyre S, Mitchie S, Nazareth I, Petticrew M. Developing and evaluating complex interventions: The new Medical Research Council guidance. BMJ. 2008;337(7676):979-983.

15. Fahner JC, Beunders AJM, Heide A Van Der, et al. Interventions Guiding Advance Care Planning Conversations: A Systematic Review. J Am Med Dir Assoc. 2019;20(3):227-248.

16. Fahner JC, Thölking TW, Rietjens JAC, van der Heide A, van Delden JJM, Kars MC. Towards advance care planning in pediatrics: a qualitative study on envisioning the future as parents of a seriously ill child. Eur J Pediatr. 2020 Mar 19 [Epub ahead of print].

17. Lin CP, Evans CJ, Koffman J, Armes J, Murtagh FEM, Harding R. The conceptual models and mechanisms of action that underpin advance care planning for cancer patients: A systematic review of randomised controlled trials. Palliat Med. 2019;33(1):5-23.

18. Popay J, Roberts H, Sowden A, et al. Guidance on the Conduct of Narrative Synthesis in Systematic Reviews A Product from the ESRC Methods Programme; London, United Kingdom: Institute for Health Research; 2006.

19. Waldman E, Wolfe J. Palliative care for children with cancer. Nat Rev Clin Oncol. 2013;10(2):86-93.

20. Verberne LM, Kars MC, Schouten-van Meeteren AYN, et al. Aims and tasks in parental caregiving for children receiving palliative care at home: a qualitative study. Eur J Pediatr. 2017;176(3):343354.

21. Verberne LM, Kars MC, Schouten-van Meeteren AYN, et al. Parental experiences and coping strategies when caring for a child receiving paediatric palliative care: a qualitative study. Eur J Pediatr. 2019;178:1075-85. 
22. Kars MC, Duijnstee MS, Pool A, Van Delden JJ, Grypdonck MH. Being there: Parenting the child with acute lymphoblastic leukaemia. J Clin Nurs. 2008;17(12):1553-1562.

23. Kars M, Grypdocnk M, Van Delden J. Being a Parent of a Child With Cancer Throughout the Endof-Life Course. Oncol Nurs Forum. 2011;38(4):2011.

24. Donovan HS, Ward S. A Representational Approach to Patient Education. J Nursing Scholarship. $2001 ; 33: 3,211-216$

25. Fried TR, Bullock K, Iannone L, O'Leary JR. Understanding advance care planning as a process of health behavior change. J Am Geriatr Soc. 2009;57(9):1547-1555.

26. Stroebe $\mathrm{M}$, Schut $\mathrm{H}$. The dual process model of coping with bereavement: Rationale and description. Death Stud. 1999;23(3):197-224.

27. Kars M, Grypdocnk M, De Korte-Verhoef $M$, et al. Parental experience at the end-of-life in children with cancer: 'preservation' and 'letting go' in relation to loss. Support Care Cancer. 2011;19:27-35.

28. Mack JW, Wolfe J, Cook EF, Grier HE, Cleary PD, Weeks JC. Hope and prognostic disclosure. J Clin Oncol. 2007;25(35):5636-5642.

29. Håkansson Eklund J, Holmström IK, Kumlin T, et al. "Same same or different?" A review of reviews of person-centered and patient-centered care. Patient Educ Couns. 2019;102(1):3-11.

30. Schulz R, Czaja SJ, McKay JR, Ory MG BS. Intervention Taxonomy (ITAX): Describing Essential Features of Interventions. Am J Heal Behav. 2010;34(6):811-821.

31. Back AL, Fromme EK, Meier DE. Training Clinicians with Communication Skills Needed to Match Medical Treatments to Patient Values. J Am Geriatr Soc. 2019;67(S2):S435-S441.

\section{Appendices}

Topic lists Developmental phase

Topic lists Pilot phase 
Chapter 7

Advance care planning for children with life-limiting conditions: content and characteristics of conversations based on the IMplementing Pediatric Advance Care Planning Toolkit

\author{
Jurrianne C. Fahner \\ Johannes J.M. van Delden \\ A. van der Heide \\ Judith C. Rietjens \\ Marijke C. Kars
}

Submission in progress 


\section{Abstract}

Background: Advance care planning (ACP) is a strategy to explore patient values, goals and preferences for future care and treatment, with attention to the physical, psychological, social and spiritual domains. The IMplementing Pediatric Advance Care Planning Toolkit (IMPACT) aims to support a holistic approach of ACP for children with life-limiting conditions and their families.

Aim: To identify the content and characteristics of ACP conversations and related documentation based On IMPACT.

Methods: Eighteen clinicians caring for children with life-limiting conditions were trained to conduct ACP conversations based on IMPACT. A thematic analysis was performed on the audio record and documentation of an ACP conversation with 26 families of children with life-limiting conditions. In total five children, 26 mothers and 15 fathers participated in an ACP conversation.

Results: ACP conversations based on IMPACT had a family-centered content, giving insight in the families' perspectives on living with illness, quality of life and underlying family values. The conversations provided some insight in the families' aims and wishes regarding their child's and families' future. Goals and preferences for future care and treatment were less specified during the conversations. Communication attitudes of clinicians entailed evasive patterns when it came to sensitive issues, including the child's endof-life.

Conclusion: ACP conversations with families of children with life-limiting conditions using IMPACT led to an insight in families' perspectives regarding living with illness and family values, yet translation of these perspectives into goals and preferences for future care and treatment was seen to a limited extent. Evasive communication patterns might contribute to a less comprehensive approach of ACP. 


\section{Introduction}

Advance care planning (ACP) is increasingly seen as an important strategy to align future care and treatment with individual patient goals and preferences. ${ }^{1}$ ACP involves identification, discussion and documentation of goals and preferences for future care and treatment. ${ }^{1}$ In the care for children with life-limiting conditions, ACP needs a holistic, family-centered approach with attention to the physical, psychological, social and spiritual domains. ${ }^{2}$

Parents are willing to anticipate the future, but they need a gradual approach with a caring attitude from clinicians, including acknowledgment of their challenging context, their expertise as parents and attention to their child as a unique person. ${ }^{3,4}$ Children with capacity to be involved in $A C P$, report to value an active participation, yet they struggle with the impact of their goals and preferences on their families. ${ }^{5,6}$ Clinicians emphasize the added value of ACP in providing care concordant with goals and preferences of children and their families, however they experience barriers as prognostic uncertainty, finding the right time to initiate ACP and the fear of triggering emotional distress within a family. ${ }^{7}$

Few pediatric ACP programs have been developed to overcome these barriers. ${ }^{8,9}$ However, insight in the components of programs and in the ACP process itself when using these programs is often lacking. The more detailed and extensively investigated approaches focus on evaluating end-of-life preferences among adolescents and young adults with specific diseases, such as Acquired Immunodeficiency Syndrome and cancer as an outcome of ACP. ${ }^{10,11}$

Generic ACP interventions for children with life-limiting conditions, aimed at an early introduction of ACP in disease trajectories, are scarce. Therefore, the IMplementing Pediatric Advance Care planning Toolkit (IMPACT) was developed recently. ${ }^{12}$ IMPACT aims to facilitate a holistic approach of ACP by providing guidance to ACP conversations with attention to the physical, psychological, social and spiritual domains. By using IMPACT, children with life-limiting conditions together with their families and clinicians, can explore and share their perspectives on living with illness and living well to achieve a shared understanding of their goals and preferences for future care and treatment. IMPACT supports attention to the voice of the child in ACP and a caring attitude from clinicians to families throughout the ACP process. 
As part of a larger pilot study, children with life-limiting conditions, their families and clinicians used IMPACT to facilitate ACP. The pilot study reveals insight in actual ACP conversations. Current insights in the characteristics of pediatric ACP conversations are mainly based on reported experiences of families and clinicians in hindsight, without knowing what happened in the actual ACP process they participated in. ${ }^{2,13,14}$ Insight in actual ACP conversations is needed to identify to what extent key elements of pediatric ACP are integrated in conversations and to achieve an understanding of communication characteristics that may influence the outcome of ACP as perceived by families and clinicians. Therefore, this study aims to provide insight in the content and characteristics of actual ACP conversations, when guided by a structured intervention as IMPACT.

\section{Methods}

\section{Study design}

This study was designed as a multicenter qualitative study using an inductive thematic analysis to evaluate the characteristics of ACP conversations based on IMPACT. ${ }^{15-17}$ The COmprehensive consolidated criteria for REporting Qualitative research (COREQ) were used to structure the study report. ${ }^{18}$

An overview of the content of IMPACT is presented in Table 1 . The key element of the intervention is a conversation guide to structure ACP conversations. It supports clinicians to explore the child's and parents' perspectives on living with illness, living a good life, values and goals and preferences for future care and treatment. Besides guidance in exploring the families' perspective, it provides prompts to integrate the clinicians' expertise in the conversation. The conversation guide has four steps: clarifying the conversation aim, exploring families' values and preferences, discussing decision making and goals of care and rounding off with a closing summary and defining next steps. The guide is not intended to be used as a checklist or a rigid script, but provides guidance to clinicians when having ACP conversations. Beside the conversation guide, IMPACT provides information leaflets about ACP for clinicians, children and families, a documentation format for ACP conversations and a clinician training in communication attitude and skills relevant in ACP. 
Table 1 Description IMPACT intervention

\begin{tabular}{|c|c|}
\hline IMPACT materials & Aim and description \\
\hline $\begin{array}{l}\text { - Information leaflets for parents and } \\
\text { children }\end{array}$ & $\begin{array}{l}\text { To prepare parents and families for an ACP } \\
\text { conversation by clarifying the concept of ACP } \\
\text { and providing prompt questions to think about } \\
\text { what is important to them when facing the } \\
\text { future. The booklet for children contains "fill in } \\
\text { the blank line" exercises to stimulate the } \\
\text { child's involvement in the ACP process. }\end{array}$ \\
\hline - Information brochure for clinicians & $\begin{array}{l}\text { To educate clinicians about the ACP concept } \\
\text { and to provide recommendations for } \\
\text { integrating ACP into their daily practice. }\end{array}$ \\
\hline $\begin{array}{l}\text { Preparation card for clinicians to invite } \\
\text { families for an ACP conversation. }\end{array}$ & $\begin{array}{l}\text { To support clinicians in inviting children and } \\
\text { parents for an ACP conversation. The card } \\
\text { provides recommendations on how to arrange } \\
\text { an appointment. }\end{array}$ \\
\hline $\begin{array}{l}\text { - Conversation guides for ACP } \\
\text { conversations with children and } \\
\text { parents together and with parents } \\
\text { alone }\end{array}$ & $\begin{array}{l}\text { To support the clinician to structure the } \\
\text { conversation, to pay attention to the voice of } \\
\text { the child, to address difficult topics gradually } \\
\text { and to integrate medical expertise in the } \\
\text { conversation. Conversation topics include the } \\
\text { child's identity, living a good life, living with } \\
\text { illness, the role of the parents, facing the } \\
\text { future, decision-making, and preferences for } \\
\text { care and treatment. }\end{array}$ \\
\hline $\begin{array}{l}\text { Documentation format for use by } \\
\text { HCPs, children, and parents }\end{array}$ & $\begin{array}{l}\text { To report and summarize the content of the } \\
\text { conversation aligned to the structure of the } \\
\text { conversation. This document can be filed in } \\
\text { the medical record and be kept by the family. }\end{array}$ \\
\hline $\begin{array}{l}\text { - Pocket guide summarizing key } \\
\text { elements of IMPACT }\end{array}$ & $\begin{array}{l}\text { To provide clinicians a reminder of key ACP } \\
\text { topics when having conversations. }\end{array}$ \\
\hline IMPACT clinician training & Aim and description \\
\hline - Two-day clinician training & $\begin{array}{l}\text { To educate clinicians on the concept of ACP, } \\
\text { on coping with serious illness and on the } \\
\text { theoretical background of IMPACT. } \\
\text { To practice effective communication attitudes } \\
\text { and skills by role plays with use of } \\
\text { professional actors and communication } \\
\text { trainers. }\end{array}$ \\
\hline
\end{tabular}




\section{Study population}

The study focused on ACP conversations based on IMPACT with children with life-limiting conditions, their parents and clinicians. Life-limiting conditions are conditions where there are no curative treatment options left, and conditions where a cure might be possible, but could still lead to death. ${ }^{19}$

Clinicians were purposively recruited from five pediatric university hospitals, the Dutch national pediatric oncology center, a pediatric hospice and a pediatric home care organization. Contact persons in the participating centers informed the clinicians about the study and invited them to participate. Clinicians were eligible if they (1) were taking care of children with life-limiting conditions as a physician or a specialized nurse, (2) were able to participate in the two-day IMPACT training program and (3) were able to perform ACP conversations in their daily practice as part of the study. Variation was sought with respect to the clinicians' subspecialty, work setting and experience. Clinicians participated in the 2-day IMPACT training and subsequently invited families from their daily practice to participate in an ACP conversation. The training days were planned eight weeks apart to be able to integrate reflections on first experiences from daily practice in the second training day. Clinicians were invited to start inclusion of families after day one.

Families were eligible for study participation if (1) having a child diagnosed with a life-limiting condition, (2) Dutch-speaking and (3) willing to have an ACP conversation about their child as part of the study. The clinicians identified eligible families, informed them about the study and asked for consent to share their contact information with the researchers. One researcher (JF) contacted the families, give more information about the study and asked for consent. The researcher reported the consent to the clinician and the clinician scheduled an ACP conversation as part of the study. Children participated in the ACP conversation and study as was indicated as appropriate by the family.

The research ethics committee of the University Medical Center Utrecht determined that the study was exempt from review under the Medical Research Involving Humans Act (November 14, 2018; Reference number: 18-770/C). All participants provided written informed consent. 


\section{Data collection}

Data consisted of the audio records of ACP conversations, the documentation of the conversations in the medical file and demographic data of the participants. Data were collected from February 2019 to September 2019. Both clinicians and families completed a background questionnaire. All ACP conversations were audio recorded and transcribed verbatim. Documentation of the ACP conversation as added to the medial file, was sent to the research team by the clinician. Families were provided with a format to summarize and document the conversation for their own and were asked to return a copy of the file to the researcher. All personally identifiable information was coded and removed from the data files.

\section{Data analysis}

A thematic analysis was performed to explore the characteristics of the ACP conversations and the related documentation based on IMPACT. Researcher triangulation was ensured to improve reliability and validity of the analysis. The thematic analysis consisted of three phases. ${ }^{15,17}$ Firstly, the core researchers (JF, MCK) individually (re)read the transcripts of five individual ACP conversations and interviews to get familiar with common aspects and phrases. Two researchers (JF, MCK) individually analyzed and coded meaningful fragments in the light of the research question and compared interpretations. The meaning of the separate text fragments was determined by interpreting them in light of the whole conversation. ${ }^{20}$ During the second phase, new interviews were read and discussed by two researchers (JF, MCK). One researcher (JF) coded all transcripts, supported by the software program Nvivo 12. Initial codes were recoded, resulting in an adapted code list with themes and concepts at a more conceptual level. ${ }^{16}$ Lastly, the research team identified key themes and related subthemes. The researchers went back and forth between the different steps to guarantee constant comparison. Code saturation was reached on a conceptual level. ${ }^{21}$

\section{Results}

Eighteen clinicians, 11 physicians and 7 nurses, participated in the study. All clinicians attended the first training day. The second training day was attended by 12 clinicians. Reasons for 
absence were personal circumstances $(n=4)$ and duties at work $(n=2)$. Fourteen clinicians had ACP conversations with families as part of the study. Two of these clinicians had only attended training day one. Reasons mentioned by clinicians for not including any families in the study were personal distress while participating in the study $(n=1)$, personal circumstances $(n=1)$, and no eligible families identified during the study period $(n=2)$. Twenty-seven cases of children with life-limiting conditions, aged 6 months to 29 years, were included in the study. Two children, aged over 18, were still receiving pediatric care due to severe cognitive impairment and grow retardation. Twenty-six mothers and 15 fathers participated in the conversations. The child itself participated in five ACP conversations. Thirteen ACP conversations took place after training day one and 14 after training day two. One audio tape was removed from the recorder accidentally, resulting in 26 audio records of ACP conversations. Seven ACP conversations took place at home. Eight conversations were conducted by two participating clinicians together. In 15 conversations both parents were involved. All participant characteristics are reported in Table 2.

Three key observations were identified from the data. It was observed that ACP conversations based on IMPACT had a family-centered content, that goals of care were often not specified and that communication patterns with an evasive character occurred regarding sensitive topics. 
Table 2 Baseline characteristics participants

\begin{tabular}{|c|c|}
\hline Characteristics of health care professionals $(n=18)$ & n (\%)* \\
\hline $\begin{array}{l}\text { Gender } \\
\text { Female }\end{array}$ & $18(100)$ \\
\hline \multicolumn{2}{|l|}{ Age $(n=18)$} \\
\hline 40-50 years & $12(67)$ \\
\hline $50-60$ years & $3(17)$ \\
\hline$\geq 60$ years & $3(17)$ \\
\hline \multicolumn{2}{|l|}{ Profession } \\
\hline Nurse & $7(39)$ \\
\hline Physician & $11(61)$ \\
\hline \multicolumn{2}{|l|}{ Working experiences in pediatrics } \\
\hline $5-10$ years & $2(11)$ \\
\hline $10-15$ years & $2(11)$ \\
\hline $15-20$ years & $5(28)$ \\
\hline $20-25$ years & $3(17)$ \\
\hline $25-30$ years & $2(11)$ \\
\hline$\geq 30$ years & $4(22)$ \\
\hline \multicolumn{2}{|l|}{ Subspecialty } \\
\hline General practitioner in pediatric hospice & $1(6)$ \\
\hline Home care & $2(11)$ \\
\hline Hospice care & $1(6)$ \\
\hline Intensive Care & $3(17)$ \\
\hline Neurology & $2(11)$ \\
\hline Oncology & $1(6)$ \\
\hline Palliative Care & $3(17)$ \\
\hline Profound Intellectual and multiple disabilities & $1(6)$ \\
\hline \multicolumn{2}{|l|}{ Number of conducted ACP conversations in study per clinician } \\
\hline 0 & $4(22)$ \\
\hline 1 & $3(17)$ \\
\hline 2 & $5(28)$ \\
\hline 3 & $4(22)$ \\
\hline 4 & $1(6)$ \\
\hline 5 & 0 \\
\hline 6 & $1(6)$ \\
\hline \multicolumn{2}{|l|}{ Characteristics of parents $(n=41)$} \\
\hline \multicolumn{2}{|l|}{ Parents participating in ACP conversation } \\
\hline Female & $26(63)$ \\
\hline \multicolumn{2}{|l|}{ Age $(n=32)$} \\
\hline$\leq 29$ years & $4(13)$ \\
\hline $30-40$ years & $5(16)$ \\
\hline $40-50$ years & $16(50)$ \\
\hline$\geq 50$ years & $7(22)$ \\
\hline \multicolumn{2}{|l|}{ Marital stage } \\
\hline Married/cohabiting & $38(93)$ \\
\hline Not cohabiting & $3(73)$ \\
\hline Nationality & \\
\hline
\end{tabular}




\begin{tabular}{|c|c|}
\hline $\begin{array}{l}\text { Dutch } \\
\text { Other }\end{array}$ & $\begin{array}{c}40(98) \\
1(2)\end{array}$ \\
\hline $\begin{array}{l}\text { Level of education }(n=32) \\
\text { Secondary school } \\
\text { Vocational education } \\
\text { High school } \\
\text { University }\end{array}$ & $\begin{array}{c}10(31) \\
8(25) \\
10(31) \\
4(13)\end{array}$ \\
\hline $\begin{array}{l}\text { Religion }(\mathrm{n}=40) \\
\text { None } \\
\text { Roman Catholic } \\
\text { Protestant } \\
\text { Islam } \\
\text { Jewish } \\
\text { Other }\end{array}$ & $\begin{array}{l}14(35) \\
7(18) \\
6(15) \\
4(10) \\
1(3) \\
1(3)\end{array}$ \\
\hline Characteristics of children $(n=$ & \\
\hline $\begin{array}{l}\text { Gender } \\
\text { Female }\end{array}$ & $16(59)$ \\
\hline $\begin{array}{l}\text { Age at participation pilot study } \\
0-5 \text { years } \\
5-10 \text { years } \\
10-15 \text { years } \\
15-18 \text { years } \\
\geq 18 \text { years }\end{array}$ & $\begin{array}{l}7(26) \\
5(19) \\
6(22) \\
6(22) \\
3(11)\end{array}$ \\
\hline $\begin{array}{l}\text { Diagnosis } \\
\text { Congenital brain disorder } \\
\text { Congenital heart disease } \\
\text { Epilepsy syndrome } \\
\text { Gastrointestinal disorder } \\
\text { Genetic disorder } \\
\text { Metabolic disease } \\
\text { Neuromuscular disease } \\
\text { Oncology } \\
\text { Unknown } \\
\end{array}$ & $\begin{array}{l}2(7) \\
1(4) \\
3(11) \\
1(4) \\
6(22) \\
6(22) \\
6(22) \\
1(4) \\
1(4) \\
\end{array}$ \\
\hline $\begin{array}{l}\text { Child's age at diagnosis }(n=24) \\
<1 \text { year } \\
1-5 \text { years } \\
\geq 5 \text { years }\end{array}$ & $\begin{array}{c}9(38) \\
11(46) \\
4(17) \\
\end{array}$ \\
\hline $\begin{array}{l}\text { Siblings } \\
\text { None } \\
1 \\
2 \\
>2 \\
\end{array}$ & $\begin{array}{c}4(15) \\
8(30) \\
12(44) \\
3(11) \\
\end{array}$ \\
\hline $\begin{array}{l}\text { Children participating in... } \\
\text { ACP conversation }\end{array}$ & 5 (19) \\
\hline
\end{tabular}




\section{Characteristics of ACP conversations based on IMPACT}

Most conversations started with a clarification of the goal of the conversation. This was most often framed as a conversation to identify what parents considered most important for their child's future care and treatment. Some clinicians used the study as a reason for having the conversation. Other clinicians labeled the conversation specifically as 'different' from prior conversations, indicating the conversation was not just a regular consultation.

Some clinicians followed the structure of the conversation guide quite strict, whereas others followed their own structure and integrated topics of the conversation guide in the conversation. Within the ACP conversations most topics as provided by the IMPACT conversation guide were addressed. Table 3 provides quotations to illustrate the content of the topics.

In the few conversations where children participated ( $n=5$, age range 10-23 years), the child was the primary conversation partner, with additional perspectives given by the parents. Most children used the information leaflet with the 'fill in the blank lines' exercise they had prepared at home to ask questions or share perspectives they considered important with the clinician. Two out of five children used to booklet to address their concerns regarding death and dying in the conversation themselves.

When the child itself was not involved in the conversation, few parents explicitly discussed perspectives from their child's point of view apart from their own perspectives. This mainly involved how certain treatments or symptoms were experienced by their child in the parents' perception. This was often followed by the parents' view on the quality of life of the child. The parental representation of the child's perspective consisted of examples of what their child had told them about living with illness. If the child was not able to communicate due to their age or developmental state, the conversations showed the child's perspective as perceived by the parents based on observations of their child's behavior or well-being. Although the IMPACT conversation guide provides questions to explore the child's perspective through the parents, few clinicians actively asked for the child's perspective, when the child was not involved in the conversation. 
Table 3 Illustrative quotes of ACP conversation topics as guided by the IMPACT conversation guide

\begin{tabular}{|c|c|}
\hline $\begin{array}{l}\text { Topic IMPACT } \\
\text { conversation guide, } \\
\text { conversations }(\mathbf{n}) \\
\end{array}$ & Illustrative quotes \\
\hline \multicolumn{2}{|l|}{ Step 1: Introduction } \\
\hline $\begin{array}{l}\text { Goal of the } \\
\text { conversation }(n=20)\end{array}$ & $\begin{array}{l}\text { Case } 18 \text { (girl, four years, metabolic disorder): } \\
\text { Clinician: Today we are going to talk about what you think is important for the care of your daughter and about your } \\
\text { perspectives regarding your child's and family's future. By talking about these issues in time, we aim to align the care } \\
\text { provided to your daughter with her best interests and your preferences and goals. }\end{array}$ \\
\hline \multicolumn{2}{|r|}{$\begin{array}{lll} & \end{array}$} \\
\hline Child's identity $(n=22)$ & $\begin{array}{l}\text { Case } 1 \text { (boy, eight years, metabolic disorder) : } \\
\text { Clinician: How would you describe your son? } \\
\text { Mother: He is a very sunny personality. He is somewhat introvert as well, sometimes he will let any issues just pass. He } \\
\text { does not want to hurt anyone, you know. He really has a strong motivation, otherwise he would not have come this far, } \\
\text { he is a fighter. He has been ill a lot, but he is still our sunshine. He really creates a bond within our family. That is very } \\
\text { special. }\end{array}$ \\
\hline $\begin{array}{l}\text { Illness experience } \\
(n=23)\end{array}$ & $\begin{array}{l}\text { Case } 12 \text { (girl, } 13 \text { years, neuromuscular disease): } \\
\text { Clinician: What does your illness mean to you? } \\
\text { Child: Well it means I cannot do all the stuff like other kids. But this does not mean that it is a burden to me, that I } \\
\text { cannot live with it, that is not how I feel it like. }\end{array}$ \\
\hline Quality of life $(n=15)$ & $\begin{array}{l}\text { Case } 23 \text { (boy, } 16 \text { years, neurologic disease): } \\
\text { Mother: For me, her quality of life is the most important. I check out on her, how she... she still has this radiance about } \\
\text { her, she enjoys so many things still. So from my point of view, that balance shows me, yes, there is still a good quality of } \\
\text { life. }\end{array}$ \\
\hline $\begin{array}{l}\text { Expectations for the } \\
\text { future including hopes } \\
(n=24)\end{array}$ & $\begin{array}{l}\text { Case } 15 \text { (boy, three years, neurologic disease): } \\
\text { Clinician: What do you hope for? For your child? For yourself? } \\
\text { Mother: I hope that we will have our son with us for a very long period of time. That he is feeling happy. I think about } \\
\text { this a lot. It is easier said than done, but if he shows us it is enough, I will give up. That sounds weird. I mean, I think I } \\
\text { can have peace with it then. But it is easier said than done. }\end{array}$ \\
\hline
\end{tabular}




\begin{tabular}{|c|c|}
\hline Role of parents $(n=24)$ & $\begin{array}{l}\text { Case } 15 \text { (boy, three years, neurologic disease): } \\
\text { Clinician: What sort of a parent would you like to be to your son? } \\
\text { Mother: I want to be there for him when he needs me, always. I do make fun of it sometimes, I say we are like a } \\
\text { conjoined twin. Where he is, I am. I can feel his feelings. I follow his path, walk with him side by side and support him } \\
\text { always. }\end{array}$ \\
\hline $\begin{array}{l}\text { Views on life and } \\
\text { sources of strength } \\
(\mathrm{n}=20)\end{array}$ & $\begin{array}{l}\text { Case } 14 \text { (girl, three years, genetic disorder): } \\
\text { Clinician: Where do you get support and strength from? } \\
\text { Mother: I think I get my strength from the kids. They do take a lot of energy, but give me so much, this keeps me going } \\
\text { And from my religion as well. I was raised in the faith, this gives me strength. }\end{array}$ \\
\hline $\begin{array}{l}\text { Fears and worries } \\
(\mathrm{n}=21)\end{array}$ & $\begin{array}{l}\text { Case } 1 \text { (boy, eight years, metabolic disorder): } \\
\text { Clinician: What is your greatest fear? } \\
\text { Mother: My greatest fear is that it (his death) will happen here (in the hospice). That I won't be with him, that keeps } \\
\text { going on in my mind. The idea that I might not have seen his last smile, that I did not talk to him anymore. That is my } \\
\text { biggest fear, no one can take it away. When my phone rings, these thoughts come up immediately. }\end{array}$ \\
\hline $\begin{array}{l}\text { Clinician's expertise on } \\
\text { the future }(n=11)\end{array}$ & $\begin{array}{l}\text { Case } 10 \text { (boy, two years, metabolic disorder): } \\
\text { Father: If he would have difficulties breathing, then we will not say: this is it. We do not agree on that. We want every } \\
\text { effort to be made to keep him alive. } \\
\text { Clinician: If you son develops difficulties breathing, and we have the time at that moment to think about different care } \\
\text { options, we both have to know that he has lower chances to recover from a need for respiratory support, compared to } \\
\text { children with a good health. }\end{array}$ \\
\hline $\begin{array}{l}\text { Goals and preferences } \\
\text { for care in general } \\
(\mathrm{n}=23)\end{array}$ & $\begin{array}{l}\text { Case } 18 \text { (girl, four years, metabolic disorder): } \\
\text { Clinician: What do you think is important for the care and treatment of your daughter? } \\
\text { Mother: Uh..., for me it is important to focus on her and her best interest. And that the treatments are manageable and } \\
\text { bearable for her. I do not want to keep going when it becomes uncomfortable to her. }\end{array}$ \\
\hline $\begin{array}{l}\text { Goals and preferences } \\
\text { for care at differing } \\
\text { stages of illness } \\
(n=14)\end{array}$ & $\begin{array}{l}\text { Case 21, boy, } 14 \text { years, metabolic disorder): } \\
\text { Clinician: What would you consider important if your son became acutely ill? } \\
\text { Mother: I know...I think we need to act accordingly. Look, I can imagine when his dystonia and spasms get very worse } \\
\text { and the medications won't help, he might say that it is enough. I will look for help then. His physician said so as well: } \\
\text { then you contact me, and we will make a plan. He does not have to suffer. I do not want that at all. }\end{array}$ \\
\hline
\end{tabular}




\begin{tabular}{|c|c|}
\hline $\begin{array}{l}\text { Summary exploration } \\
(n=16)\end{array}$ & $\begin{array}{l}\text { Case } 4 \text { (girl, } 16 \text { years, metabolic disorder): } \\
\text { Clinician: I will summarize the conversation, please give any additions when needed. Your daughter is basically a very } \\
\text { happy girl, but nowadays you do not see her being happy that often anymore. There are a very few moments left she } \\
\text { enjoys. Mostly when she can cuddle with someone, or go outside in the sunshine, or listen to some music. There are } \\
\text { these worries, about when to say goodbye to her and treat her suffering more intensively. She is suffering. Who decides } \\
\text { when to take the next step? How do we decide? That is complicated. There is also the fear that she will suffer from } \\
\text { shortness of breath. I think this is it more or less? }\end{array}$ \\
\hline \multicolumn{2}{|c|}{ Step 3: Decision-making } \\
\hline $\begin{array}{l}\text { Designation decision- } \\
\text { making roles }(n=21)\end{array}$ & $\begin{array}{l}\text { Case 1, (boy, eight years, metabolic disorder): } \\
\text { Mother: Most decisions are made by the parents. But last time, I said to his physician, where is his voice? His voice } \\
\text { counts too. His clinician pulled away and kept quiet for some time. My son is not cognitively impaired, he knows very } \\
\text { well what his options are. }\end{array}$ \\
\hline $\begin{array}{l}\text { Establish care goals } \\
(n=14)\end{array}$ & $\begin{array}{l}\text { Case } 22 \text { (boy, two years, genetic disorder): } \\
\text { Clinician: We discussed about goals of care, I think most important is that we support him to follow his own course. } \\
\text { Mother: I think so too. } \\
\text { Clinician: That we focus on what he shows to us. } \\
\text { Mother: Yes, that we focus on his needs, and that we leave the things, he seems not to care about. }\end{array}$ \\
\hline $\begin{array}{l}\text { Clinician's expertise on } \\
\text { care goals }(n=14)\end{array}$ & $\begin{array}{l}\text { Case } 10 \text { (boy, two years, metabolic disorder): } \\
\text { Father: We are no physicians, so when he gets sick, we need to go to the hospital. } \\
\text { Clinician: I think so too. As I discussed last time with you, I also prefer him to be examined by a physician, to see what } \\
\text { we can do to make him feel better. And when this does not work out at that moment, when all options have been } \\
\text { considered, that we then... yes... } \\
\text { Mother: We would not want him to be in pain. } \\
\text { Father: No, we want him to get all treatments and opportunities possible, until he shows himself... } \\
\text { Mother: Yes, that he can no longer endure this. } \\
\text { Clinician: And when there are no options left, then we have to make sure he is not in pain, like you say, that he is not } \\
\text { suffering. }\end{array}$ \\
\hline $\begin{array}{l}\text { Preferences for } \\
\text { documentation }\end{array}$ & $\begin{array}{l}\text { Case } 7 \text { (girl, } 11 \text { years, epilepsy syndrome): } \\
\text { Father: I think it is important to write down in her care plan, that we as her parents are very well informed and that we } \\
\text { will address it when... That they know on the ICU how we think about her treatment, that we won't get the question } \\
\text { again after three days of admission, like: do you really want this for your child? Please read her care plan, you know. }\end{array}$ \\
\hline \multicolumn{2}{|l|}{ Step 4: Rounding off } \\
\hline $\begin{array}{l}\text { Summary of the } \\
\text { conversation }(n=15)\end{array}$ & $\begin{array}{l}\text { Case } 24 \text { (boy, congenital brain disorder): } \\
\text { Clinician: To summarize, please correct me if I am wrong, your son has a prominent role in the family, he enjoys many }\end{array}$ \\
\hline
\end{tabular}




\begin{tabular}{|l|l|}
\hline & $\begin{array}{l}\text { things in life, as do you with him and the other children. So that is actually a good situation. You do have your fears and } \\
\text { worries, such as that your son will pass away suddenly. And there are other worries, about the epilepsy in the morning. } \\
\text { We will make a plan for that. Speaking of any treatment preferences, you are quite clear. You want to give him every } \\
\text { chance and we will give him all treatments possible. }\end{array}$ \\
\hline Other topics $(n=18)$ & $\begin{array}{l}\text { Case 6 (girl, six years, metabolic disease): } \\
\text { Clinician: Are there any other topics you would like to discuss at this moment? } \\
\text { Mother: No, I think we have covered everything. }\end{array}$ \\
\hline $\begin{array}{l}\text { Follow-up } \\
\text { conversation }(n=4)\end{array}$ & $\begin{array}{l}\text { Case 23 (girl, 16 years, neurologic disease): } \\
\text { Clinician: How about making a next appointment in December? And earlier if needed, we will give each other a call. } \\
\text { Mother: Yes, we stay in touch. }\end{array}$ \\
\hline
\end{tabular}




\section{A family-centered content of the conversation}

It was observed that the conversations had an explorative, family-oriented character mainly, instead of a disease-oriented content. Table 4 provides quotations to illustrate the findings. In some conversations, actual symptoms or questions regarding current treatment were discussed briefly, yet most conversations had a focus on the families' perspectives on living with illness, the families' coping strategies and on managing daily life. Even when not specifically asked about these topics, parents shared a lot of information about their life as a parent and family caring for a child with a life-limiting condition. The perspectives on living with illness gave insight in the consequences of the illness on the daily life of the child, the impact for siblings and for the parents themselves.

It was observed that a family-centered approach in the conversation, created opportunities to discuss values and preferences of the family regarding the future. When parents spoke about living with illness, the conversation often moved forward to discussing quality of life. This could entail explicitly discussing quality of life as a concept or it resulted in sharing more implicit perspectives regarding life values that gave some insight in the parental perspectives on quality of life. It depended on next questions of the clinician whether implicit perspectives were explored more extensively. Some parents addressed a shift in the quality of life of their child over the years, or looked forward to possible changes in quality of life in the future. This gave some insight in the goals parents had for their child, such as no further decline, no discomfort or to keep the opportunity to participate in normal life.

Children that were involved in the conversation shared their perspectives on living with illness, regarding their current life and their future. This included experiences at school or with friends, dreams for the future and preferences on how to be approached by clinicians.

When talking about the impact of living with illness, parents and children often gave insight in the way they coped with their current life. This occurred spontaneously or was initiated by questions from the clinician about the families' sources of strengths. Some parents tend to normalize the situation of their child. This happened mainly in cases where the child was physically active and participating in daily life. Other parents talked about caring for their child 
as a way to live a meaningful life themselves. They mentioned to see their child as a special gift to care for very cautiously, making the care for their child their life's goal. Others emphasized the life lessons they learned trough caring for their child, such as living day by day, enjoying daily life and keeping a positive attitude. Some parents reported to experience difficulties in coping with their child's illness and future due to the child's suffering they observed or feared for, the fear of loosing their child to death and the impact of the child's illness on their personal development and family life. In some cases, discussing the family's coping strategies revealed insight in underlying life values, such as religious beliefs or adherence to the intrinsic value of life itself. In some cases, these underlying values were related to a wish for active treatment in case a deterioration of the child's condition might occur.

Besides insight in living with illness and ways of coping, many parents talked about how they managed their daily life. This concerned how they organized the practical care for their child day by day and what challenges they experienced. Some parents emphasized the burden of daily care giving. Few parents related the actual burden of care giving to preferences for their child's future. This included no active prolongation of their child's life in order to regain a life for themselves or no initiation of treatments that would make life unmanageable, such as therapies that require recurrent admissions or were provided only in hospitals far away from home.

\section{Difficulties in defining goals of future care and treatment}

Although the family-centered content of the conversations revealed some insight in the families' values and preferences regarding the future, a comprehensive summary of goals and preferences for future care and treatment was rarely observed in the conversations. Following the family's narrative on living with illness and living a good life seemed quite natural for the clinicians. However, structuring and guiding the conversation towards a shared understanding of goals of future care based on the families' values and preferences was observed in a limited number of conversations.

It was often unclear if the rationale of exploring the family's narrative regarding living with illness was understood by the clinician in the context of the conversation aim. Most clinicians did not explicitly summarize family values from their narratives to move forward to more specific 
preferences for care and treatment or to help families to clarify goals of future care and treatment. Only few clinicians provided information and shared their perspectives on the child's illness and future in order to help families to specify their preferences in relation to goals of care. This mostly entailed information about life sustaining treatments or expected benefits or disadvantages of those treatments for the child.

Whereas the view of parents on quality of life for their child was discussed in most conversations, this was not often explored further in relation to goals and preferences for future care and treatment. Without exploring mutual understanding of quality of life in relation to care and treatment, clinicians and families often talked about comfort care in general without understanding each other's perspectives regarding the meaning of this concept for this individual child. For example, it turned out during the conversations, that parents who aimed for comfort care for their child, did not relate this to treatment limitations by definition, while it seemed that clinicians thought certain invasive therapies do not be align with comfort care. In some conversations this led to a more complicated course of the conversation, where it took some time to identify each other's point of view. Some parents took a role themselves in clarifying concepts as quality of life and comfort care in relation to goals of care, when the clinician did not ask any clarifying questions. Other parents stated they preferred all care and treatment options to be used for their child without any limitations, yet the ongoing conversation spontaneously revealed they had limitations in mind, such as no chronic respiratory support at home.

Very few clinicians made recommendations based on the explored values and preferences of the family. Recommendations were more often seen in relation to questions about current therapies, that passed along during the conversations. Very few conversations included a welldefined follow-up plan, indicating the conversations were not embedded in a structured ongoing process of defining and reviewing goals of care over time.

\section{Communication patterns with an evasive nature}


Three communication patterns were identified from the conversations that contribute to a lack of clarity regarding preferences and goals for future care and treatment. These patterns were mixed framing, exploration by assumptions and lack of deeper explorations.

Firstly, clinicians used mixed framing when introducing topics that are generally associated with more intense emotions, such as perspectives regarding a poor prognosis or the end of life of the child. Mixed framing involved mentioning an unfavorable outcome for the child or worst case scenario, followed by mentioning the opposite possibility. By focusing on possible positive scenario's at the end of a statement or a question, when trying to explore more difficult topics, families reacted to the favorable scenario and less information was obtained about what would be important to the family if the child's condition would deteriorate. This limited insights in the family's fears, worries and preferences when talking about the future.

Secondly, exploration by making assumptions regarding the parents' perspectives on ACP topics was another communication pattern that limited insights in the families' perspectives. The clinician made a statement about the family's perspective waiting for their response to this statement. In this way the clinician framed the family's perspective, instead of framing the actual situation and exploring the family's perspective by open-ended questions. This leaded the conversation away from discovering deeper underlying values and emotions.

Thirdly, deeper explorations of the families' perspectives were not actively initiated by clinicians so often. Parents could give a clue regarding their perspectives on the burden of care, the quality of life of their child, end-of-life themes or goals of care and treatment, that were not always responded to by clinicians. Clinicians often used indirect or unclear openings to explore perspectives regarding death and dying, that did not lead to a deeper exploration of the families' perspective. Clinicians who used more concrete questions and kept asking additional questions, received more comprehensive reactions from parents, which made the parents' perspectives more clear. 


\section{Table 4 Key findings regarding the content of ACP conversations based on IMPACT}

\begin{tabular}{|c|c|}
\hline Theme & Quote \\
\hline \multicolumn{2}{|c|}{ Family-centered conversations } \\
\hline $\begin{array}{l}\text { - Impact of living } \\
\text { with illness }\end{array}$ & $\begin{array}{l}\text { Case } 14 \text { (girl, } 3 \text { years, genetic disorder) : } \\
\text { Clinician: What does your child's illness mean to you and your family? } \\
\text { Mother: It is all about her. Our family life is focused on her. That is how it has } \\
\text { developed over the years. I can barely imagine our life before her, a lot has changed. } \\
\text { We stay at home, no holidays anymore, activities with the other kids are limited. Yes, } \\
\text { it is just a lot that has changed, but you do not think about it... }\end{array}$ \\
\hline $\begin{array}{l}\text { - Families coping } \\
\text { strategies }\end{array}$ & $\begin{array}{l}\text { Case } 15 \text { (boy, three years, neurologic disorder): } \\
\text { Clinician: I do not see any resistance in you, like I see sometimes with other parents... } \\
\text { Mother: Well, I do have my moments, I cry a lot then at home, or I talk about it with } \\
\text { my mom or write it down. But it is not my way of coping to dwell on the negative. } \\
\text { That won't get us anywhere. Talking does help me a lot. Luckily, I really do talk } \\
\text { much... }\end{array}$ \\
\hline $\begin{array}{l}\text { - Managing daily } \\
\text { life }\end{array}$ & $\begin{array}{l}\text { Case } 13 \text { (girl, ten years, neuromuscular disease): } \\
\text { Clinician: How do you manage this all? I mean, being awake } 5 \text { to } 6 \text { times per night...? } \\
\text { Mother: The first one to wake up... } \\
\text { Father: She sleeps next to our room with the doors open, she calls us and who hears } \\
\text { her first... } \\
\text { Child: ... comes to me. }\end{array}$ \\
\hline \multicolumn{2}{|c|}{ Difficulties in defining goals of care } \\
\hline $\begin{array}{l}\text { - Lack of } \\
\text { comprehensive } \\
\text { summary }\end{array}$ & $\begin{array}{l}\text { Case } 12 \text { (girl, } 13 \text { years, neuromuscular disease): } \\
\text { Clinician: Yes, okay, we discussed a lot, mainly about your perspectives. I will try to } \\
\text { summarize it. I think, you focus on what is needed in the moment and for the future } \\
\text { you will just see what is going to happen. And if needed, you will make any decisions } \\
\text { in the moment. }\end{array}$ \\
\hline $\begin{array}{l}\text { - Limited } \\
\text { clarification of } \\
\text { concepts }\end{array}$ & $\begin{array}{l}\text { Case } 19 \text { (girl, } 17 \text { years, genetic disorder): } \\
\text { Clinician: Comfort care, you mentioned. Anything else you consider important that we } \\
\text { did not discuss? } \\
\text { Mother: I think we discussed what is most important to us. } \\
\text { Father: Well, you could discuss more extensively, I mean, when you say comfort care, } \\
\text { what do you mean by that? } \\
\text { Clinician: Yes, what do you mean by comfort care... } \\
\text { Father: So you can discuss more about that... (end of discussion about comfort care) }\end{array}$ \\
\hline \multicolumn{2}{|c|}{ Communication patterns with an evasive nature } \\
\hline - Mixed framing & $\begin{array}{l}\text { Case } 20 \text { (girl, one year, brain tumor): } \\
\text { Clinician: The aim of the conversation is to talk about her future. Your daughter has a } \\
\text { life-limiting condition, but she is doing very well. } \\
\text { Father: Yes, she definitely is. That might change, but she is doing extremely well. }\end{array}$ \\
\hline $\begin{array}{l}\text { - Exploration by } \\
\text { assumptions }\end{array}$ & $\begin{array}{l}\text { Case } 3 \text { (girl, } 18 \text { years, genetic disorder) : } \\
\text { Clinician: There are a lot of things you know about her illness of course and there } \\
\text { might be things you are worried about. } \\
\text { Father: I can not say we have any worries at this moment. You are talking about her } \\
\text { illness... } \\
\text { Clinician: Yes, that is my language } \\
\text { Father: In our opinion, she is not ill. She is very happy. She is playing a lot and doing }\end{array}$ \\
\hline
\end{tabular}




\begin{tabular}{|l|l|}
\hline & well. \\
\hline - Lack of deeper & Case 8 (girl, 16 years, neuromuscular disease): \\
& Clinician: What does your illness mean to you, looking towards your future? \\
& Child: I don't know that for sure. I try not to think about the future that much, I get a \\
& little bit upset when thinking about the future. So I do not think about it a lot. I know \\
& my future does not look so bright. \\
& Mother: In some way you think about your future, like thinking about a future job, \\
& getting your drivers license... Your try to stay positive, however there are these \\
& moments... that's sometimes difficult, you know. \\
& Clinician: And how about living by yourself for example? \\
\hline
\end{tabular}

\section{Documentation}

Summaries of all included ACP conversations were documented by the clinician in the medical file of the child. The comprehensiveness of the documentation varied largely among clinicians. Some clinicians documented a nearly literal representation of the conversation, whereas others formulated a comprehensive summary with a conclusion of the conversation related to goals of care. Interestingly, the documentation could contain a more comprehensive summary of the conversation, including a description of goals of care, compared to the audio record of the conversation itself. Some clinicians shared the documentation with the family before adding a final version to the medical file. In some cases this led to an ongoing reflection on the conversation of both clinicians and families and to a more detailed description of discussed goals of care and related treatment limitations. Eight families did return their own completed documentation format to the researchers. This provided a short reflection of their perspectives as discussed in the conversation. Whereas in the conversation many issues were discussed, the family's documentation provided additional insight in what they considered most important regarding their child's life.

\section{Discussion}

This study evaluated the content of actual ACP conversations based on IMPACT. By using IMPACT, ACP conversations had a family-oriented content and provided insight in the family's living with illness, their coping strategies and strategies to manage daily life. This resulted in some insight in their underlying values and preferences regarding their child's future and family life. However, specific preferences for future care and treatment were discussed to a limited 
extent. Family's values and general preferences for the child, were hardly explored in relation to goals of future care and treatment. In many conversations, it remained unclear how the explored perspectives could inform future care and aligned treatment decisions. An indirect way of communicating was seen especially when clinicians and families addressed more sensitive issues, such as the child's end of life. Evasive communication patterns might have led to less specific outcomes of the ACP conversation in terms of insight in the family's perspectives regarding sensitive themes and a shared understanding of goals of future care.

ACP aims to identify, share, document and review goals and preferences of future care and treatment based on individual patient values with attention to the physical, psychological, social and spiritual domain. ${ }^{1}$ We identified that ACP conversations with a holistic approach and a family-centered content, provided insight in the families' perspectives on these different domains. These perspectives can function as a base for further exploration of underlying values and preferences for care and treatment. Mutual understanding of care goals is a key element of high quality care for patients with life-limiting conditions and needed to provide care that is aligned to what is most important to the patient. ${ }^{22}$ To achieve a mutual understanding of goals of future care and treatment and making aligned treatment decisions when appropriate, a holistic insight in the families' perspectives alone is not sufficient. Besides exploring patient values and preferences to a deeper extent, clinicians need to share their expertise in a nonthreatening manner to define goals of care that can inform shared-decision making. Clinicians need to become more skilled in translating family values into goals and preferences of care and treatment, both early and later on in disease trajectories. Clinicians need to frame the patients' situation when necessary, provide prognostic information and explain the pros and cons of different treatment options when appropriate. ${ }^{22,23}$ In our study, it was observed that few clinicians shared their perspectives from their medical expertise. If they did, this mainly concerned perspectives regarding invasive treatments. Pediatricians reported to feel comfortable to discuss treatment limitations in the content of ACP. ${ }^{7,24,25}$ Defining treatment limitations seems still to be seen as an important outcome of ACP. ${ }^{26,27}$ The need for discussing life-sustaining treatment options might be perceived as less relevant for ACP conversations earlier in disease trajectories. As a result, clinicians might feel less confident about the outcomes 
of the ACP conversations earlier in disease trajectories and feel difficulties to integrate content of the ACP conversations, as the families' perspectives on living with illness and living a good life, in the care for the child and family. In cases were goals of care were defined, often general concepts were used such as comfort care. However, the meaning of this concept might not be the same within families and needs further exploration, apart from the clinicians' views on the meaning of comfort care.

This study finds its strengths in the analysis of ACP conversations itself. Studies in pediatric ACP often evaluate experiences with ACP without any insight in the ACP process. Experiences might be positive, but not related to the content of the conversation in terms of key elements of ACP. This study makes visible what occurs when clinicians are trained in ACP and subsequently have conversations with families in their daily practice. The pragmatic study design was closely related to medial practice, revealing how clinicians might use interventions in their practice.

The findings of the study are limited by the sample of participants. The participating clinicians were often already involved in pediatric palliative care and had an interest in ACP. This might have influenced the content of the conversations. Besides this, clinicians were often involved in the included cases for a longer period of time. Prior conversations might have influenced the content of the ACP conversation based on IMPACT, thereby limiting the insight in the role of the intervention itself. The clinicians themselves informed families about the study, which might have led to inclusion of families that were more prone to think about future care. Unfortunately, due to the recruitment procedure the number of families refusing to participate in ACP or the study is lacking. Although IMPACT has the intention to actively involve children in ACP, only few children were included in the study. Involvement of children in ACP is known to be a challenge due to lack of quality of communication with children and complex relationships with families and medical teams. ${ }^{14,28}$ Further research is needed to develop strategies to give the voice of the child a more prominent place in ACP.

This study is a first step in exploring actual ACP conversations based on IMPACT in general pediatrics. Further research is needed on how to stimulate both clinicians and families to achieve a shared understanding of care goals as a result of ACP and to evaluate them over time. 
Ongoing training of clinicians and coaching on the job, as well as empowerment of patients to share their preferences might contribute to further development of ACP. In our study, involvement in ACP was depended of the intrinsic motivation of individual clinicians. Further research needs to identify essential elements to implement ACP in healthcare institutions as standard of care.

\section{Conclusion}

ACP conversations conducted by clinicians using IMPACT in cases of children with life-limiting conditions explore the families' perspectives on living with illness and living a good life. Underlying family values emerged from this conversations. Using the families' perspectives and values to identify and clarify goals and preferences of future care and treatment occurred to a limited extent. Clinicians need to guide the conversations more clearly from the families' perspectives towards defining goals of care in order to make ACP contributable to care aligned to the child's and family's values and preferences.

\section{References}

1. Rietjens JAC, Sudore PRL, Connolly M, et al. Review Definition and recommendations for advance care planning: an international consensus supported by the European Association for Palliative Care. Lancet Oncol. 2017;18(9):e543-e551.

2. Orkin J, Beaune L, Moore $C$, et al. Toward an understanding of advance care planning in children with medical complexity. Pediatrics. 2020;145(3).

3. Fahner JC, Thölking TW, Rietjens JAC, van der Heide A, van Delden JJM, Kars MC. Towards advance care planning in pediatrics: a qualitative study on envisioning the future as parents of a seriously ill child. Eur J Pediatr. 2020 Mar 19. Online ahead of print.

4. Lotz JD, Daxer M, Jox RJ, Borasio GD, Führer M. " Hope for the best, prepare for the worst ": A qualitative interview study on parents ' needs and fears in pediatric advance care planning. Palliat Med. 2016;31(8):764-771.

5. Needle JS, Peden-McAlpine C, Liaschenko J, et al. "Can you tell me why you made that choice?": A qualitative study of the influences on treatment decisions in advance care planning among 
adolescents and young adults undergoing bone marrow transplant. Palliat Med. 2020;34(3):281290.

6. Lyon ME, McCabe MA, Patel KM, D'Angelo L. What do adolescents want? An exploratory study regarding end-of-life decision-making. J Adolesc Heal. 2004;35(6):529.e1-529.e6.

7. Durall A, Zurakowski D, Wolfe J. Barriers to conducting advance care discussions for children with life-threatening conditions. Pediatrics. 2012;129(4):e975-82.

8. Myers J, Cosby R, Gzik D, et al. Provider Tools for Advance Care Planning and Goals of Care Discussion: A Systematic Review. Am J Hosp Palliat Med. 2018;35(8):1123-1132.

9. Lotz JD, Jox RJ, Borasio GD, Führer M. Pediatric advance care planning: A systematic review. Pediatrics. 2013;131(3):e873-e880.

10. Lyon ME, Garvie P a, McCarter R, Briggs L, He J, D'Angelo LJ. Who Will Speak for Me? Improving End-of-Life Decision-Making for Adolescents With HIV and Their Families. Pediatrics. 2009;123(2):e199-e206.

11. Zadeh S, Pao M, Wiener L. Opening end-of-life discussions: how to introduce Voicing My CHOiCESTM, an advance care planning guide for adolescents and young adults. Palliat Support Care. 2015;13(3):591-599.

12. Fahner JC, Rietjens JAC, van der Heide A, Milota MM, van Delden JJM, Kars MC. Evaluation Showed That Stakeholders Valued the Support Provided by the Implementing Pediatric Advance Care Planning Toolkit. Acta Paediatr. 2020 May 20. Online ahead of print.

13. DeCourcey DD, Silverman M, Oladunjoye A, Wolfe J. Advance Care Planning and Parent-Reported End-of-Life Outcomes in Children, Adolescents, and Young Adults With Complex Chronic Conditions. Crit Care Med. 2019;47(1):101-108.

14. Hein K, Knochel K, Zaimovic V, et al. Identifying key elements for paediatric advance care planning with parents, healthcare providers and stakeholders: A qualitative study. Palliat Med. 2020;34(3):300-308.

15. Thomas DR. A General Inductive Approach for Analyzing Qualitative Evaluation Data. Am J Eval. 2006;27(2):237-246. 
16. Braun V, Clarke V. Using thematic analysis in psychology. Qual Res Psychol. 2006;3(2):77-101.

17. Dierckx Casterle BD De, Gastmans C, Bryon E, Denier Y. QUAGOL: A guide for qualitative data analysis. Int J Nurs Stud. 2012; 49: 360-371.

18. Tong A, Sainsbury P, Craig J. Consolidated criteria for reporting qualitative research ( COREQ ): a 32-item checklist for interviews and focus groups. Int J Qual Heal Care. 2007;19(6):349-357.

19. ACT. A Guide to the Development of Children's Palliative Care Services. Third Edit.; 2009.

20. Kvale S. InterViews: An Introduction to Qualitative Research Interviewing. Thousand Oaks, California: SAGE publications; 1996.

21. Hennink MM, Kaiser BN, Marconi VC. Code Saturation Versus Meaning Saturation: How Many Interviews Are Enough? Qual Health Res 27(4):591-608

22. Bernacki RE, Block SD. Communication About Serious Illness Care Goals A Review and Synthesis of Best Practices. Jama Intern Med. 2014;174(12):1994-2003.

23. Childers JW, Back AL, Tulsky JA, Arnold RM. REMAP: A framework for Goals of Care Conversations. J Oncol Pr. 2017;13(10):e844-e850.

24. Sanderson A, Hall AM, Wolfe J. Advance Care Discussions: Pediatric Clinician Preparedness and Practices. J Pain Symptom Manage. 2016;51(3):520-528.

25. Sanderson A, Zurakowski D, Wolfe J. Clinician perspectives regarding the do-not-resuscitate order. JAMA Pediatr. 2013;167(10):954-958.

26. Fahner JC, Rietjens JAC, van der Heide A, van Delden JJM, Kars MC. Survey of paediatricians caring for children with life-limiting conditions found that they were involved in advance care planning. Acta Paediatr. 2019;00(July):1-8.

27. Taylor J, Booth A, Beresford B, Phillips B, Wright K, Fraser L. Specialist paediatric palliative care for children and young people with cancer: A mixed methods systematic review. Palliat Med. 2020 Jun; 34(6): 731-775.

28. Hughes $B, O^{\prime} B$ rien MR, Flynn A, Knighting K. The engagement of young people in their own advance care planning process: A systematic narrative synthesis. Palliat Med. 2018;32(7):1147-1166. 
Appendices

Topic lists Pilot phase 
Chapter 8

Experiences with an advance care planning intervention for children with life-limiting conditions: a qualitative study of families and clinicians using the IMplementing Pediatric Advance Care Planning Toolkit

\author{
Jurrianne C. Fahner \\ Johannes J.M. van Delden \\ Judith C. Rietjens \\ Agnes van der Heide \\ Marijke C. Kars
}

Submission in progress 


\section{Abstract}

Background: Advance care planning is a strategy to explore goals and preferences for future care and treatment aligned to patient values. The IMplementing Pediatric Advance Care Planning Toolkit (IMPACT) provides a strategy to involve clinicians and families of children with life-limiting conditions in ACP from a holistic, family-oriented point of view, starting early in disease trajectories.

Aim: To explore how clinicians, children with life-limiting conditions and their parents experience ACP conversations based on IMPACT.

Methods: A multicenter, qualitative interview study using inductive thematic analysis was conducted. A total of 27 cases of children with life-limiting conditions were included in the study from February 2019 to December 2019. Interviews with 18 clinicians, 24 mothers, 8 fathers and 3 children were conducted.

Results: Clinicians and families of children with life-limiting conditions valued to be involved in ACP conversations based on IMPACT. Although it confronted both parents and clinicians with the impact of caring for a child with a life-limiting condition, sharing the family's narrative resulted in a stronger relation between families and clinicians. This relation was valued as a good foundation to share values and preferences for future care and treatment. However, an added value of the conversation regarding defining goals of future care and treatment was experienced to a limited extent.

Conclusion: ACP conversations based on IMPACT facilitate family-centered conversations, that are valued by families of children with life-limiting conditions and their clinicians. The meaning of the family's narrative in relation to goals and preferences of future care and treatment needs ongoing conversations and coaching on the job of clinicians initiating those conversations. 


\section{Introduction}

Parents of children with life-limiting conditions experience decision-making in the best interest of their child as a challenging, yet central task in the care for their child, while balancing between a focus on disease and symptom control and a focus on creating a life worth living for their child. ${ }^{1}$ Especially, anticipating future medical decision-making and defining preferences and goals for future care and treatment are complicated due to prognostic uncertainty, a focus on the here and now among families and reluctance among clinicians to initiate conversations about sensitive issues such as quality of life of the child and the child's end of life. ${ }^{2,3}$

Advance care planning is increasingly emphasized as a strategy to identify, share, document and review preferences and goals for future care and treatment. ${ }^{4}$ In pediatrics, ACP is often promoted as a valuable strategy to discuss future care and treatment by clinicians, adolescents and parents, yet ACP is perceived as emotional challenging and often postponed, even during the last phase of life. ${ }^{5,6}$ This hinders the exploration of the families' perspectives on future care and treatment earlier in disease trajectories. Initiation of ACP early in disease trajectories creates opportunities to think about values, goals and preferences without the actual need of decisionmaking during those early and ongoing conversations. ${ }^{7}$

Few well-investigated interventions to implement ACP in pediatrics exist, which mostly focus on end-of-life themes in specific disease populations, such as oncology patients, children admitted to the intensive care unit and children living with acquired immune deficiency syndrome. ${ }^{8}$

To facilitate ACP in pediatrics for children with life-limiting conditions in general, starting early in disease trajectories and continuing until the last phase of life, we developed the IMplementing Pediatric Advance Care Planning Toolkit (IMPACT). ${ }^{9,10}$ IMPACT aims to support clinicians and families to participate in ACP from a holistic point of view, with attendance to the voice of the child and with a caring attitude for families that acknowledges their challenging context, during the ACP process. The need for a holistic mind-set in pediatric ACP is increasingly acknowledged. ${ }^{7}$ Therefore, IMPACT focuses on what children with life-limiting conditions and their parents consider important to themselves and as a family when facing their future, instead of a focus on preferences for specific treatment options. This approach involving the physical, 
psychological, social and spiritual domain, intents to support ACP as an individualized, familyoriented process that can overcome clinicians' barriers to initiating ACP conversations, such as perceived parental unreadiness, fears to trigger intense emotions and taking away hope. ${ }^{2,3}$ IMPACT aims to structure ACP conversations by providing topics and verbal examples to stay close to the families' perspectives, whereas at the same time it provides clinicians opportunities to share their expertise regarding the future of the child.

Current research on ACP in pediatrics is often based on the experiences of clinicians and bereaved parents with ACP in general, without knowing what the ACP process itself entailed in detail. ${ }^{11-14}$ This limits current insights in the perspectives of families and clinicians on specific elements of the ACP process. Beside this, bereaved parents may look back on their ACP process with a different perspective after experiencing the actual loss of their child. Therefore, we conducted a qualitative study among children with life-limiting conditions, their parents and clinicians, who were recently involved in ACP using IMPACT, both early and later on in disease trajectories. This study aims to gain insight in the actual experiences of children with life-limiting conditions, their parents and clinicians using IMPACT and in their perceived usefulness of a standardized ACP approach.

\section{Methods}

Design

A multicenter, interpretative qualitative interview study using an inductive thematic analysis was conducted to explore early experiences with IMPACT. ${ }^{15-17}$ The COmprehensive consolidated criteria for REporting Qualitative research (COREQ) were used to structure the study report. ${ }^{18}$

\section{IMPACT intervention}

An overview of the content of IMPACT is presented in Table 1. The intervention provides materials to support the identification, discussion and documentation of values, goals and preference for care and treatment, starting from the families' perspective on living with illness. The key element of the intervention is a conversation guide to structure ACP conversations. It supports clinicians to explore the child's and parents' perspectives on the child's identity, living 
with illness, living a good life, expectations for the future, and preferences for future care and treatment. Besides guidance in exploring the families' perspective, it provides prompts to integrate the clinicians' expertise in the conversation. The conversation guide has four steps: clarifying the conversation aim, exploring families' values and preferences, discussing goals of care and decision making and rounding off with a closing summary and defining next steps. The guide is not intended to be used as a checklist or a rigid script, but to provide guidance to clinicians when having ACP conversations. Besides the conversation guide, IMPACT provides information leaflets about ACP for clinicians, children and families, a documentation format for ACP conversations and a clinician training in communication attitudes and skills relevant in ACP.

\section{Study population}

Clinicians involved in the care for children with life-limiting conditions were purposively recruited from five academic pediatric hospitals, the Dutch pediatric oncology centre, a pediatric hospice and a pediatric home care organization in collaboration with local contact persons. Clinicians were eligible to participate in the study if taking care of children with life-limiting conditions as a physician or a specialized nurse, willing to participate in the two-day IMPACT training and able to perform ACP conversations in their daily practice as part of the study. Lifelimiting conditions were defined as conditions where there are no curative treatment options left, and where a cure might be possible, but could still lead to a premature death. ${ }^{19}$ Variation was sought with respect to the clinicians' subspecialty and experience. After attending the IMPACT training, clinicians invited parents of children with life-limiting conditions for an ACP conversation, as considered appropriate by the clinician. Clinicians informed parents about the study and asked consent to share their contact information with the research team. One researcher (JF) contacted the families, provide more information about the study and asked for consent to participate. The researcher reported the consent to the clinician and the clinician planned an ACP conversation as part of the study. Families were eligible for participation if having a child diagnosed with a life-limiting condition, Dutch-speaking and willing to have a ACP conversation about their child. Children themselves participated in the ACP conversation and study, as was indicated as appropriate by the parents. 
The research ethics committee of the University Medical Center Utrecht determined that the study was exempt from review under the Medical Research Involving Humans Act (November 14, 2018; Reference number: 18-770/C). All participants provided written informed consent.

Table 1 Description IMPACT intervention

\begin{tabular}{|c|c|}
\hline IMPACT materials & Aim and description \\
\hline $\begin{array}{l}\text { - Information leaflets for parents and } \\
\text { children }\end{array}$ & $\begin{array}{l}\text { To prepare parents and families for an ACP } \\
\text { conversation by clarifying the concept of ACP } \\
\text { and providing prompt questions to think about } \\
\text { what is important to them when facing the } \\
\text { future. The booklet for children contains "fill in } \\
\text { the blank line" exercises to stimulate the } \\
\text { child's involvement in the ACP process }\end{array}$ \\
\hline - Information brochure for clinicians & $\begin{array}{l}\text { To educate clinicians about the ACP concept } \\
\text { and to provide recommendations for } \\
\text { integrating ACP into their daily practice. }\end{array}$ \\
\hline $\begin{array}{l}\text { Preparation card for clinicians to invite } \\
\text { families for an ACP conversation. }\end{array}$ & $\begin{array}{l}\text { To support clinicians in inviting children and } \\
\text { parents for an ACP conversation. The card } \\
\text { provides recommendations on how to arrange } \\
\text { an appointment }\end{array}$ \\
\hline $\begin{array}{l}\text { - Conversation guides for ACP } \\
\text { conversations with children and } \\
\text { parents together and with parents } \\
\text { alone }\end{array}$ & $\begin{array}{l}\text { To support the clinician to structure the } \\
\text { conversation, to pay attention to the voice of } \\
\text { the child, to address difficult topics gradually } \\
\text { and to integrate medical expertise in the } \\
\text { conversation. Conversation topics include the } \\
\text { child's identity, living a good life, living with } \\
\text { illness, the role of the parents, facing the } \\
\text { future, decision-making, and preferences for } \\
\text { care and treatment. }\end{array}$ \\
\hline $\begin{array}{l}\text { Documentation format for use by } \\
\text { clinicians, children, and parents }\end{array}$ & $\begin{array}{l}\text { To report and summarize the content of the } \\
\text { conversation aligned to the structure of the } \\
\text { conversation. This document can be filed in } \\
\text { the medical record and be kept by the family }\end{array}$ \\
\hline $\begin{array}{l}\text { - Pocket guide summarising key } \\
\text { elements of IMPACT }\end{array}$ & $\begin{array}{l}\text { To provide clinicians a reminder of key ACP } \\
\text { topics when having conversations }\end{array}$ \\
\hline IMPACT clinician training & Aim and description \\
\hline - Two-day clinician training & $\begin{array}{l}\text { To educate clinicians on the concept of ACP, } \\
\text { on coping with serious illness and on the } \\
\text { theoretical background of IMPACT } \\
\text { To practice effective communication attitudes } \\
\text { and skills by role plays with use of } \\
\text { professional actors and communication } \\
\text { trainers }\end{array}$ \\
\hline
\end{tabular}




\section{Data collection}

Data were collected in face-to-face semi-structured interviews with clinicians, parents and children. Data were collected from February 2019 to December 2019. Both clinicians and families completed a background questionnaire. Parents and children were interviewed by JF about their experiences shortly after the ACP conversation. Clinicians were interviewed at the end of the study by JF. The interviews were audio recorded and transcribed verbatim. Interviews lasted 3090 minutes and were conducted at a location of the participants' preference. An interview guide, based on literature and expertise of the research team, structured the interviews (See Appendix). Topics included perspectives on the aim of ACP, perspectives regarding their experiences with the ACP conversations, experiences with the IMPACT materials and clinician training.

\section{Data analysis}

A thematic analysis was performed to explore the experiences of clinicians, families and children with an ACP conversation based on IMPACT. ${ }^{16}$ Researcher triangulation was ensured to improve reliability and validity of the analysis. The thematic analysis consisted of three phases. ${ }^{15,17}$ First, the researchers (JF, MCK) individually (re)read the transcripts of five individual interviews to get familiar with common aspects and phrases. Two researchers (JF, MCK) individually analysed and coded meaningful fragments in the light of the research question and compared interpretations together. The meaning of the separate text fragments was determined by interpreting them in light of the whole interview. ${ }^{20}$ Initial codes were recoded, resulting in an adapted code list. ${ }^{16}$ During the second phase, new interviews were read and discussed by two researchers (JF, MCK). The code tree was evaluated and adjusted. One researcher (JF) coded all interviews, supported by the software program Nvivo 12. Lastly, the research team identified key themes and related subthemes. The researchers went back and forth between the different steps to guarantee constant comparison. Code saturation was reached on a conceptual level. ${ }^{21}$ 


\section{Results}

Figure 1 gives an overview of the study flow. Eighteen clinicians participated in the IMPACT training. Fourteen of them conducted ACP conversations with a total of 27 families within the study. Twenty-five families participated in the subsequent interviews. The child was involved in the ACP conversation in five cases and in the study interview in three cases. All 18 clinicians were interviewed at the end of the study. Seven ACP conversations took place at home. Eight conversations were conducted jointly by a nurse and a physician. Children were included at different stages of their disease. Participant characteristics are reported in Table 2.

Figure 1 Overview of study flow

\section{Clinicians participating in IMPACT training $(n=18)$ (physicians $n=11$, nurses $n=7$ ) Day 1: 18 clinicians Day 2: 12 clinicians}

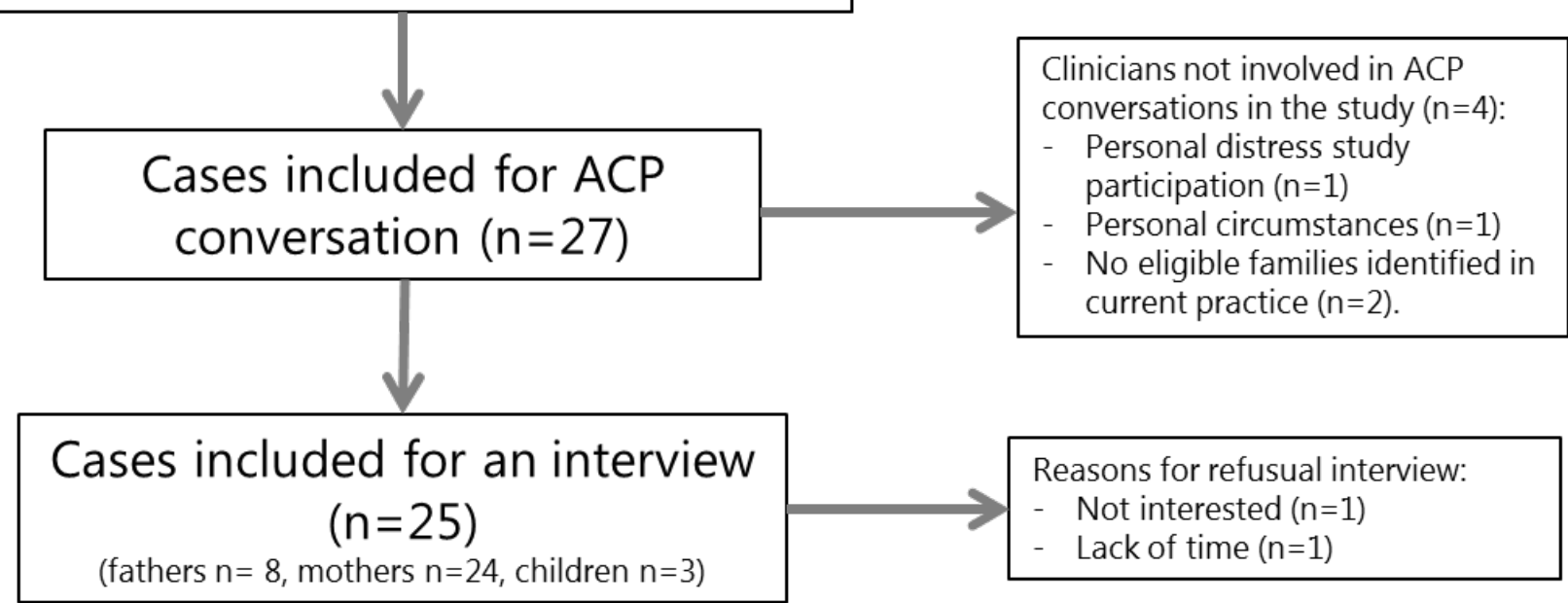

Drop out training day 2:

Personal circumstances $(n=3)$ Difficulties planning $(n=2)$ Personal distress participating in study $(\mathrm{n}=1)$

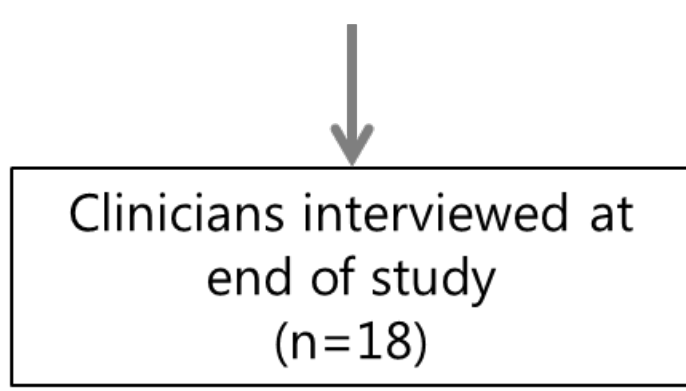


Table 2 Baseline characteristics participants

\begin{tabular}{|c|c|}
\hline & n (\%) ${ }^{*}$ \\
\hline \multicolumn{2}{|l|}{ Characteristics of health care professionals $(n=18)$} \\
\hline $\begin{array}{l}\text { Gender } \\
\quad \text { Female }\end{array}$ & $18(100)$ \\
\hline $\begin{array}{l}\text { Age } \\
\quad 40-50 \text { years } \\
50-60 \text { years } \\
\geq 60 \text { years }\end{array}$ & $\begin{array}{l}12(67) \\
3(17) \\
3(17)\end{array}$ \\
\hline $\begin{array}{l}\text { Profession } \\
\text { Nurse } \\
\text { Physician }\end{array}$ & $\begin{array}{c}7(39) \\
11(61)\end{array}$ \\
\hline $\begin{array}{l}\text { Working experiences in pediatrics } \\
5-10 \text { years } \\
10-15 \text { years } \\
15-20 \text { years } \\
20-25 \text { years } \\
25-30 \text { years } \\
\geq 30 \text { years }\end{array}$ & $\begin{array}{l}2(11) \\
2(11) \\
5(28) \\
3(17) \\
2(11) \\
4(22)\end{array}$ \\
\hline $\begin{array}{l}\text { Subspecialty } \\
\text { General practitioner in pediatric hospice } \\
\text { Home care } \\
\text { Hospice care } \\
\text { Intensive Care } \\
\text { Neurology } \\
\text { Oncology } \\
\text { Palliative Care } \\
\text { Profound Intellectual and multiple disabilities }\end{array}$ & $\begin{array}{l}1(6) \\
2(11) \\
1(6) \\
3(17) \\
2(11) \\
1(6) \\
3(17) \\
1(6)\end{array}$ \\
\hline $\begin{array}{l}\text { Number of conducted ACP conversations in study per clinician } \\
0 \\
1 \\
2 \\
3 \\
4 \\
5 \\
6\end{array}$ & $\begin{array}{l}4(22) \\
3(17) \\
5(28) \\
4(22) \\
1(6) \\
0 \\
1(6)\end{array}$ \\
\hline Characteristics of parents $(n=41)$ & \\
\hline $\begin{array}{l}\text { Parents participating in ACP conversation }(n=41) \\
\text { Female }\end{array}$ & $26(63)$ \\
\hline $\begin{array}{l}\text { Parents interviewed after ACP conversation }(n=32) \\
\text { Female }\end{array}$ & $24(75)$ \\
\hline $\begin{array}{l}\text { Age }(n=32) \\
\quad \leq 29 \text { years } \\
\quad 30-40 \text { years } \\
40-50 \text { years } \\
\quad \geq 50 \text { years }\end{array}$ & $\begin{array}{c}4(13) \\
5(16) \\
16(50) \\
7(22)\end{array}$ \\
\hline $\begin{array}{l}\text { Marital stage }(n=41) \\
\text { Married/cohabiting } \\
\text { Not cohabiting }\end{array}$ & $\begin{array}{l}38(93) \\
3(73)\end{array}$ \\
\hline
\end{tabular}




\begin{tabular}{|c|c|}
\hline $\begin{array}{l}\text { Nationality }(n=41) \\
\text { Dutch } \\
\text { Other }\end{array}$ & $\begin{array}{c}40(98) \\
1(2)\end{array}$ \\
\hline $\begin{array}{l}\text { Level of education }(n=32) \\
\text { Secondary school } \\
\text { Vocational education } \\
\text { High school } \\
\text { University }\end{array}$ & $\begin{array}{l}10(31) \\
8(25) \\
10(31) \\
4(13)\end{array}$ \\
\hline $\begin{array}{l}\text { Religion }(\mathrm{n}=40) \\
\text { None } \\
\text { Roman Catholic } \\
\text { Protestant } \\
\text { Islam } \\
\text { Jewish } \\
\text { Other }\end{array}$ & $\begin{array}{l}14(35) \\
7(18) \\
6(15) \\
4(10) \\
1(3) \\
1(3)\end{array}$ \\
\hline Characteristics of children $(n=27)$ & \\
\hline $\begin{array}{l}\text { Gender }(n=27) \\
\text { Female }\end{array}$ & $16(59)$ \\
\hline $\begin{array}{l}\text { Age at participation pilot study }(n=27) \\
0-5 \text { years } \\
5-10 \text { years } \\
10-15 \text { years } \\
15-18 \text { years } \\
\geq 18 \text { years }\end{array}$ & $\begin{array}{l}7(26) \\
5(19) \\
6(22) \\
6(22) \\
3(11)\end{array}$ \\
\hline $\begin{array}{l}\text { Diagnosis }(\mathrm{n}=27) \\
\text { Congenital brain disorder } \\
\text { Congenital heart disease } \\
\text { Epilepsy syndrome } \\
\text { Gastrointestinal disorder } \\
\text { Genetic disorder } \\
\text { Metabolic disease } \\
\text { Neuromuscular disease } \\
\text { Oncology } \\
\text { Unknown }\end{array}$ & $\begin{array}{c}2(7) \\
1(4) \\
3(11) \\
1(4) \\
6(22) \\
6(22) \\
6(22) \\
1(4) \\
1(4)\end{array}$ \\
\hline $\begin{array}{l}\text { Child's age at diagnosis }(n=24) \\
<1 \text { year } \\
1-5 \text { years } \\
\geq 5 \text { years }\end{array}$ & $\begin{array}{l}9(38) \\
11(46) \\
4(17)\end{array}$ \\
\hline $\begin{array}{l}\text { Siblings }(n=27) \\
\text { None } \\
1 \\
2 \\
>2\end{array}$ & $\begin{array}{l}4(15) \\
8(30) \\
12(44) \\
3(11)\end{array}$ \\
\hline $\begin{array}{l}\text { Children participating in... }(\mathrm{n}=27) \\
\text { ACP conversation } \\
\text { Interview after ACP conversation } \\
\text { None of the above }\end{array}$ & $\begin{array}{c}5(19) \\
3(11) \\
22(81)\end{array}$ \\
\hline
\end{tabular}


Five main perceptions were identified from the experiences of clinicians and parents involved in ACP conversations based on IMPACT. It was observed that: 1) Clinicians value a structured, yet open exploration of the families' perspectives, 2) Parents value attention to their challenging situation, even though this triggers an emotional response, 3) ACP conversations stimulate a stronger relation between families and clinicians, 4) ACP conversations are experienced as part of an ongoing process throughout the child's disease trajectories, and 5) An added value of ACP conversations regarding future care and treatment is experienced to a limited extent. Table 3 provides quotes to illustrate the findings.

Clinicians value a structured, yet open exploration of the families' perspectives in ACP

Clinicians experienced ACP as a helpful strategy to explore the perspectives of the child and family regarding their values, goals and preferences of future care and treatment on the physical, psychological, social and spiritual domain. IMPACT helped them to explore these domains in a structured way. This revealed comprehensive insights in the family's perspectives on living with illness and the meaning of living with illness for the child and the family. Clinicians reported these deeper insights in the family's life provided them a background for better understanding the families' preferences for care and treatment. They mentioned discussing the families' concerns and hopes, could help clinicians to support families in future decision making.

Clinicians emphasized the added value of the IMPACT training to feel confident in using IMPACT in their practice. Although most clinicians said the materials of IMPACT could be used without any training, they experienced the IMPACT training helped them to become familiar with the ACP topics of IMPACT. They valued the opportunity to practice verbal phrases they did not use in their regular consultations with patients. Besides this, the training helped them to respond to emotions in an adequate way and to get used to an open, explorative attitude instead of mainly informing patients during a conversation. Practicing role play before using IMPACT in their daily practice was perceived as very helpful due to the realistic scenarios and opportunities to practice with different reactions of parents when addressing sensitive issues. Clinicians mentioned this reduced their personal barriers to invite families for ACP in their practice. The training was experienced as safe, yet some clinicians mentioned the training confronted them 
with the intensity of their own emotions, when they observed an explorative approach could trigger intense emotions of parents and children in the role play. Besides this, some clinicians experienced insecurity when they were triggered to approach conversations about future care in a different way compared to what they were used to as experienced clinicians, being focused on providing information and making treatment decisions.

Clinicians experienced their role in the conversation mainly as an explorative listener. They preferred to have the conversation during a stable phase in the child's disease trajectory, without the need for any decision making at the moment. This gave them more space to openly explore the families' perspectives.

Some clinicians used the IMPACT conversation guide as a hand-held booklet during the conversations. They preferred to follow the structure of the guide closely and to have the backup phrases in front of them in case they would not know what to say during a conversation. Others were reluctant to have the guide visible on the table, being afraid families would interpret this as a lack of skills. However, clinicians agreed this had more to do with their own perception, than with the families' opinions. Families reported to experience the use of a guide during the conversation as diligent and accurate.

Four clinicians did not have any formal ACP conversations within the study. (Figure 1) However, they reported to integrate elements of IMPACT in their practice, such as questions about the meaning of living with illness and hopes for the future.

Some clinicians mentioned being involved in ACP confronted them with their own role in their profession. Both physicians and nurses perceived being involved in ACP as an important part of their professional duties. However, especially some nurses mentioned to struggle with their role in ACP due to limited decision-making power. Nurses participating in a pediatric palliative care team felt more confident regarding ACP, since the explorative character of ACP fitted their tasks within the multidisciplinary team. Besides that they felt more autonomy being involved in families as case managers. They used the ACP conversations to put forward the families' perspectives during meetings of the medical team. 
Parents value attention to their challenging context in $A C P$, even though emotions are triggered

Parents were very positive about their experiences with the ACP conversation based on IMPACT in general. They felt being known and heard during the conversations and valued the attention to their child and family beyond the medical domain. Even when the content of the conversations did not reveal new insights for both the parents and clinicians, parents appreciated the time invested to share their narratives in a structured way without constraints of time and without the need for decision-making at that moment. None of the parents experienced the conversation topics as inappropriate or too confrontational. Most parents did not have specific expectations of the conversation in advance. Although they appreciated the information leaflet to prepare themselves for the conversation, and stated the conversation fitted their expectations, most parents had difficulties to specify their expectations. They reflected on the aim of ACP in a generalized manner. Most parents mentioned to see ACP as a strategy to think about good care for their child.

Most parents mentioned the ACP conversation triggered thoughts about ongoing losses due to the child's life-limiting condition. During the ACP conversation, parents had feelings of loss when talking about prior experiences regarding the child's care and treatment or when looking back to periods where the child had been in a better condition. This confronted them with beautiful moments that had passed by and with difficult situations they had experienced as a family already. Confrontation with ongoing losses continued when facing the future during the ACP conversation that yielded perspectives regarding disease progression, maintaining care and the child's end-of-life. Many parents mentioned these thoughts had continued after the ACP conversation for a while. As such, participating in ACP was experienced as emotionally intense and energy taking by most parents, yet they valued the attention to their feelings of ongoing loss, that were part of their daily life anyway.

Three children participated in the ACP conversations and subsequent interviews. Those children reported they felt to be in the lead during the conversations and valued the attention to them as a person and in what they considered important for their future. Children did not mention any specific emotions in relation to the conversation. 
ACP conversations stimulate a stronger relation between families and clinicians

Both clinicians and parents mentioned having the ACP conversation had deepened their relationship. Clinicians reported the insight in the families' perspectives on living with illness helped them to understand the challenging context of the family. This provided them some insight in the background of the values families shared during the conversations. At the same time, hearing about the families' dealing with their challenging situation and their expectations for the future, gave rise to many emotions. Clinicians perceived the conversations as energy taking, yet valuable due to the feelings of a stronger connection. They reported this made them feel more satisfied in their job.

For parents, the interest in their personal context and acknowledgement of their challenges in caring for a child with a life-limiting condition, made them feeling heard and being known. This made them more open to share their deeper thoughts, including their hopes, fears and worries regarding the future of their child. Some families mentioned that having the conversation at their home showed so much effort of the clinician towards to the family, that this influenced their ability and willingness to share their perspectives in a positive way. Clinicians who did ACP conversations at home, were very convinced of the added value of having a conversations at the family's place, even when taking the substantial time investment into account. They mentioned parents could talk more openly in their own homes and seeing the living environment of the family gave them more insight in their way of living and increased a sense of connection.

ACP conversations are experienced as part of an ongoing process throughout the child's disease trajectories

During the interviews it appeared that clinicians and families did not regard the ACP conversation as a distinct event, but experienced it as part of an ongoing process throughout the child's disease trajectories. Most clinicians and families knew each other for some time. Therefore some ACP topics had been addressed already along the way, such as perspectives on life-sustaining treatments. However, both parents and clinicians reported to value a separate appointment for an ACP conversation, to be able to discuss topics beyond the medical domain 
and to take a step back from day-to-day issues that need to be discussed during regular consultations. However, in most cases there was no follow-up moment scheduled after the conversation. When clinicians and parents reflected on the ACP conversations during the interviews, some reported to experience some loose ends after the ACP conversation. This included the need for more clarity regarding goals and preferences for future care, more insight in mutual perspectives regarding specific treatment options and information on a follow-up plan. Clinicians and parents stated they felt free to address these issues during next regular consultations.

An added value of ACP conversations regarding future care and treatment is experienced to a limited extent

Although both clinicians and families appreciated the ACP conversations, it was more difficult for them to specify the added value of the conversations regarding future care and treatment. Some parents mentioned to value the explication of preferences for future care and treatment that had been shared before in a less comprehensive way. Others mentioned the conversation confirmed that their expertise as parents regarding goals of care for their child was seen and respected by the clinician. Some parents mentioned to expect from clinicians to take account of the parents' preferences for treatment limitations as expressed in the ACP conversation in case their child's condition might deteriorate. Parents felt they might tend to change their views regarding invasive treatments when facing their child's death. They feared this might not be in their child's best interest and expressed the need for someone to keep them focused on their initial wishes. These parents expected clinicians to be honest about the prognosis of their child and to share any new insights regarding their child's condition with them in relation to their values. Parents expressed the hope their clinician could keep them close to their initial wishes, when the fear of losing their child might drive them towards other perspectives.

Clinicians mainly referred to the gained insights in the families' perspectives on living with illness as an added value in relation to defining goals and preferences of future care and treatment. Few clinicians said the conversation led to clear goals of care and adequate anticipation of 
future scenarios. Most clinicians experienced ongoing conversations are needed to achieve a shared understanding of goals of care.

Table 3 Illustrative quotes of main experiences in ACP conversations based on IMPACT

\begin{tabular}{|c|c|}
\hline Theme & \begin{tabular}{l|l} 
Quote \\
\end{tabular} \\
\hline \multicolumn{2}{|c|}{ ACP conversations stimulate a stronger relation between families and clinicians } \\
\hline $\begin{array}{l}\text { - Insight in living } \\
\text { with illness }\end{array}$ & $\begin{array}{l}\text { Case } 12 \text { (girl, } 13 \text { years, neuromuscular disease): } \\
\text { Mother: It was a pleasant conversation. I appreciate it our clinician knows a } \\
\text { bit more about our daughter as a person, who she is apart from her } \\
\text { disease and ventilator. You know, you will need each other in difficult } \\
\text { times. For me it is important, that she (the clinician) knows the bigger } \\
\text { picture then. }\end{array}$ \\
\hline $\begin{array}{l}\text { - Deeper } \\
\text { emotional } \\
\text { connection }\end{array}$ & $\begin{array}{l}\text { Pediatric palliative care nurse: } \\
\text { During the conversations, there grows a connection, a base for future } \\
\text { decision making. That is much better than meeting in an ad hoc situation. } \\
\text { You have time to acknowledge the child as a person and the parents in } \\
\text { their parenting roles. I think people appreciate it, so does it feel to me, it } \\
\text { stimulates a stronger connection. So yes, for me it is a very good way to } \\
\text { start a conversation with parents in a structured way. That is how I feel } \\
\text { about it. } \\
\text { Case } 15 \text { (boy, three years, neurologic disorder): } \\
\text { Mother: I think if these conversations happen more often, if I had a } \\
\text { conversation like that in the other hospital before my son was admitted to } \\
\text { the intensive care unit, I could have felt some connection with that } \\
\text { physician. I could have felt supported, but now she did just turn her back } \\
\text { on us. }\end{array}$ \\
\hline \multicolumn{2}{|c|}{ ACP conversations are experienced as part of an ongoing process } \\
\hline $\begin{array}{l}\text { - Continued } \\
\text { thinking after } \\
\text { conversation }\end{array}$ & $\begin{array}{l}\text { Case } 1 \text { (male, } 8 \text { years, metabolic disease): } \\
\text { Mother: The questions that were asked kept me thinking. About his code } \\
\text { status for example. These are issues you take home, some homework to } \\
\text { think about. I think it is really important to think about the child's wishes } \\
\text { when he is approaching end of life. Does he have a say? We do not think } \\
\text { enough about that. }\end{array}$ \\
\hline \multicolumn{2}{|c|}{ Added value of the ACP conversation regarding future care and treatment } \\
\hline $\begin{array}{l}\text { - Explication of } \\
\text { more or less } \\
\text { known items }\end{array}$ & $\begin{array}{l}\text { Case } 20 \text { (girl, one year, brain tumor): } \\
\text { Mother: We've been in the hospital a lot and then you've talked to each } \\
\text { other a lot anyway. But I really liked the opportunity to settle down and talk } \\
\text { this through, having the time to ask all questions that are on my mind and } \\
\text { to think about the future together, without being interrupted. }\end{array}$ \\
\hline $\begin{array}{l}\text { - Clinician's' role } \\
\text { in safe guarding } \\
\text { initial goals of } \\
\text { care }\end{array}$ & $\begin{array}{l}\text { Case } 25 \text { (male, } 16 \text { years, gastrointestinal disorder): } \\
\text { Father: I can image that we, or may be every parent, has an instinctive } \\
\text { reaction of 'please, save my child' when it comes to an emergency } \\
\text { situation. But at this moment, when we are not at such a point, I really } \\
\text { appreciate, we can think about worst-case scenarios from another point of } \\
\text { view. So that a clinician can say to us when that moment is there: you } \\
\text { know we talked about this? You know, just to remember us of what we } \\
\text { really want for our child. }\end{array}$ \\
\hline
\end{tabular}




\section{Discussion}

This qualitative interview study assessed the experiences of families of children with life-limiting conditions and their clinicians with ACP conversations based on IMPACT. Families and clinicians reported to appreciate being involved in ACP conversations structured by IMPACT. This was mainly based on the opportunities the conversations provided to share perspectives of the family on living with illness and what they considered important for their child. Although the ACP conversations confronted parents with ongoing losses, resulting in intense emotions, the conversations were experienced as safe and worthwhile as a moment of reflection on their child's care and future. Clinicians experienced the perspectives on living with illness as insightful and helpful to understand family preferences and their attitude in decision making. An added value of the conversations regarding future care and treatment was experienced to a limited extent. Parents and clinicians had difficulties to reflect on how the conversation content could inform goals of care and future decision making.

This study reveals some key lessons about ACP, when using a structured, holistic tool as IMPACT. Whereas research shows that ACP in current practice might still have a disease-oriented approach, including a focus on treatment decisions, ${ }^{22}$ our study shows that providing a structured tool to discuss person-oriented themes, gives valuable insights in the families' perspectives on their child and family life in the context of living with illness. The exploration of life values could entail a comprehensive foundation for defining goals of future care and decision-making. ${ }^{23}$ Parents and clinicians value the family-centered approach in this study, and experienced this as an investment in their relationship. It is known that patient-clinician relationships can function as facilitators in ACP. ${ }^{11,24,25}$ Building on an attitude of caring for each other can be seen as a first step in ACP, that might facilitate ongoing ACP conversations in the future when deterioration of the child might induce the need for complex decision-making. ${ }^{26}$

The findings of this study, that IMPACT contributes to a family-centered approach of ACP and facilitates a stronger relation between families and clinicians, suggest IMPACT can be used as a tool to start ACP early in disease trajectories. ${ }^{7}$ This might be beneficial to further implementation 
of ACP in pediatrics, since research shows integration of ACP early in disease trajectories is perceived as challenging by clinicians. ${ }^{3}$

Although the structure of IMPACT is aimed at defining goals of future care and treatment as key element of $\mathrm{ACP}_{1}^{4}$ this turned out to be difficult to achieve in a single conversation. This is known from literature, where ACP is increasingly seen as an ongoing process and interventions often entail multiple conversations. ${ }^{27}$ However, even when a single conversation mainly includes the exploration and identification of family values, a comprehensive summary might elicit how the content of the conversation could inform next steps in the ACP process, even without defining specific goals of care at that moment. Clinicians need to safeguard that the shared values and preferences are used to inform future goals of care and decision making. Clinicians need to clarify the conversation aim for parents and stimulate further thoughts about the future of their child. Coaching on the job might support clinicians in their communications skills to achieve a comprehensive outcome of the conversation. ${ }^{28}$

This study finds it strengths in a diverse sample of clinicians and families participating, that reflects the usability of the intervention for children with life-limiting conditions in general. Besides this, nearly all families participating in an ACP conversation were willing to participate in the evaluating interview. The findings of the study might be influenced by the selection of participants. Clinicians might have invited families they felt comfortable with, which might have led to a positive experience anyway. Besides this it was observed that parents had difficulties to recall the specific content of the ACP conversation. Therefore their experiences might not reflect experiences with IMPACT alone, but experiences within in a longer relationship, in which repeated discussions about future care and treatment took place. Although clinicians were asked to report how many families they asked to participate in ACP during the study period, clinicians did not report this data back adequately. Therefore, it is unknown if the study sample is a selection of families that might be more willing to participate in ACP compared to others. Some clinicians conducted no or a few ACP conversations within the study. Although they reflected on the use of IMPACT during the interviews, their perspectives might be influenced by a limited use of IMPACT. The design of this study did not include repeated interviews or a longer follow-up of 
the experiences of clinicians and families. It might be interesting to evaluate how the ACP process is continued over time to determine any effects of the intervention on actual care received by the child and family in the end.

\section{Conclusion}

Clinicians and parents of children with life-limiting conditions experienced ACP conversations based on IMPACT as a valuable strategy to share the families' perspectives on living with illness and their values regarding the future of their child. The use of the families' narrative in defining goals of future care and treatment for their child was experienced to a limited extent in most cases and might need a more incisive attitude from clinicians and ongoing ACP conversations.

\section{References}

1. Verberne LM, Kars MC, Meeteren AYNS, et al. Aims and tasks in parental caregiving for children receiving palliative care at home: a qualitative study. Eur J Pediatr. 2017;176(3):343-354.

2. Fahner JC, Rietjens JAC, van der Heide A, van Delden JJM, Kars MC. Survey of paediatricians caring for children with life-limiting conditions found that they were involved in advance care planning. Acta Paediatr Int J Paediatr. 2019;00(July):1-8.

3. Durall A, Zurakowski D, Wolfe J. Barriers to conducting advance care discussions for children with life-threatening conditions. Pediatrics. 2012;129(4):e975-e982.

4. Rietjens JAC, Sudore PRL, Connolly M, et al. Review Definition and recommendations for advance care planning: an international consensus supported by the European Association for Palliative Care. Lancet Oncol. 2017;18(9):e543-e551.

5. Liberman DB, Pham PK, Nager AL. Pediatric Advance Directives: Parents' Knowledge, Experience, and Preferences. Pediatrics. 2014;134(2):E436-E443.

6. Heckford E, Beringer Jane A. Advance Care Planning: Challenges and Approaches for Pediatricians. J Palliat Med. 2014;17(9):1049-1053.

7. Orkin J, Beaune $\mathrm{L}$, Moore $\mathrm{C}$, et al. Toward an understanding of advance care planning in children with medical complexity. Pediatrics. 2020;145(3). 
8. Myers J, Cosby R, Gzik D, et al. Provider Tools for Advance Care Planning and Goals of Care Discussion: A Systematic Review. Am J Hosp Palliat Med. 2018;35(8):1123-1132.

9. Fahner JC, Rietjens JAC, van der Heide A, Milota MM, van Delden JJM, Kars MC. Evaluation showed that stakeholders valued the support provided by the Implementing Pediatric Advance Care Planning Toolkit. Acta Paediatr. 2020 May 20. Online ahead of print.

10. The IMplementing Pediatric Advance Care Planning Toolkit. Published 2019. www.kinderpalliatief.nl/impact/uk

11. Hein $\mathrm{K}$, Knochel $\mathrm{K}$, Zaimovic $\mathrm{V}$, et al. Identifying key elements for paediatric advance care planning with parents, healthcare providers and stakeholders: A qualitative study. Palliat Med. 2020;34(3):300-308.

12. Lotz JD, Jox RJ, Borasio GD, Fuhrer M. Pediatric advance care planning from the perspective of health care professionals: a qualitative interview study. Palliat Med. 2015;29(3):212-222.

13. Lotz JD, Daxer M, Jox RJ, Borasio GD, Führer M. " Hope for the best, prepare for the worst ": A qualitative interview study on parents ' needs and fears in pediatric advance care planning. Palliat Med. 2016;31(8):764-771.

14. Decourcey DD, Silverman M, Oladunjoye A, Wolfe J. Advance Care Planning and Parent-Reported End-of-Life Outcomes in Children, Adolescents, and Young Adults With Complex Chronic Conditions. Crit Care Med. 2019 Jan;47(1):101-108

15. Thomas DR. A General Inductive Approach for Analyzing Qualitative Evaluation Data. Am J Eva 2006;27(2):237-246.

16. Braun V, Clarke V. Using thematic analysis in psychol-ogy. Qual Res Psychol. 2006;3(2):77-101.

17. Dierckx de Casterle B, Gastmans C, Bryon E, Denier Y. QUAGOL: A guide for qualitative data analysis. Int J Nurs Stud. 2012;49(3):360-71

18. Tong A, Sainsbury P, Craig J. Consolidated criteria for reporting qualitative research ( COREQ ): a 32-item checklist for interviews and focus groups. Int J Qual Heal Care. 2007;19(6):349-357.

19. ACT. A Guide to the Development of Children's Palliative Care Services. Third Edit.; 2009. 
20. Kvale S. InterViews: An Introduction to Qualitative Research Interviewing. Thousand Oaks, California: SAGE publications; 1996.

21. Hennink MM, Kaiser BN, Marconi VC. Code Saturation Versus Meaning Saturation: How Many Interviews Are Enough? Qual Health Res 27(4):591-608

22. Taylor J, Booth A, Beresford B, Phillips B, Wright K, Fraser L. Specialist paediatric palliative care for children and young people with cancer: A mixed methods systematic review. Palliat Med. 2020 Jun; 34(6): 731-775.

23. Childers JW, Back AL, Tulsky JA, Arnold RM. REMAP: A framework for Goals of Care Conversations. J Oncol Pr. 2017;13(10):e844-e850.

24. Fahner JC, Thölking TW, Rietjens JAC, van der Heide A, van Delden JJM, Kars MC. Towards advance care planning in pediatrics: a qualitative study on envisioning the future as parents of a seriously ill child. Eur J Pediatr. 2020 Mar 19. [Epub ahead of print]

25. Van Vliet LM, Epstein AS. Current state of the art and science of patient-clinician communication in progressive disease: Patients' need to know and need to feel known. J Clin Oncol. 2014;32(31):3474-3478.

26. Hill DL, Miller V, Walter JK, et al. Regoaling: A conceptual model of how parents of children with serious illness change medical care goals. BMC Palliat Care. 2014;13(1):1-8.

27. Fahner JC, Beunders AJM, Heide A Van Der, et al. Interventions Guiding Advance Care Planning Conversations: A Systematic Review. J Am Med Dir Assoc. 2019;20(3):227-248.

28. Zwakman M, Pollock K, Bulli F, et al. Trained facilitators' experiences with structured advance care planning conversations in oncology: An international focus group study within the ACTION trial. BMC Cancer. 2019;19(1):1-13.

\section{Appendices}

Topic lists Pilot phase 
Chapter 9

General discussion 


\section{Introduction}

In an era with increasing medical technologies, life expectancy increases for children with lifelimiting conditions. ${ }^{1}$ These children and their families might benefit from early integration of palliative care and a person-centered approach to care, to support them in living a meaningful life with care and treatment aligned to their values, preferences and goals. ${ }^{2-4}$

Advance care planning (ACP) is a strategy aimed to promote that the provision of future care and treatment is concordant with preferences of the child and family. ACP is a communicative process that enables patients to define, to discuss and to document and review goals and preferences for future care and treatment, together with healthcare providers and family. ${ }^{5}$ ACP becomes more focused in the context of life-limiting conditions, due to the increased possibility of serious life-threating events and deterioration of the child's condition in the future. ACP involves exploration of individual values of children and families regarding the physical, physiological, spiritual and social domain. ACP might support preference congruence between adolescents and their parents, increase knowledge about care options during the end-of-life phase and provide time for decision-making based on high quality communication with clinicians. ${ }^{6}$ Children with life-limiting conditions and their parents value to be involved in planning of future care and treatment. ${ }^{7-9}$ However, multiple barriers to ACP exist among clinicians and families, such as lack of knowledge, prognostic uncertainty, avoidant coping strategies, lack of communication skills, fear for emotional distress and perceived unreadiness of families to anticipate a future that includes scenarios of losing their child. ${ }^{10-12}$

Interventions to support ACP in pediatrics for children with life-limiting conditions in general are scarce. $^{6,13}$ The few well-described and investigated interventions focus on specific disease populations, such as oncology patients, and end of life issues, thereby limiting the applicability early in disease trajectories for children with life-limiting conditions. ${ }^{14-16}$ Therefore, this thesis was aimed at the development and evaluation of a comprehensive ACP intervention to be used in pediatrics for children with life-limiting conditions and their parents, earlier in disease trajectories and continuing until the end of life to support them in the anticipation of future care and treatment aligned to their values, goals and preferences. The research questions of this 
thesis intended to contribute to three aims: 1) to identify key elements of pediatric ACP, 2) to design a pediatric ACP intervention based on these key elements and 3) to explore first experiences with the intervention. (See Table 1)

\section{Table 1. Study aims and research questions of the thesis}

\section{To identify key elements of pediatric ACP}

1.1 What are the structure, content, theoretical background and empirical evidence of adult and pediatric ACP interventions using a conversation guide? (Chapter 2)

1.2 How do clinicians and parents anticipate the future in pediatric palliative care? (Chapter 3 )

1.3 How do pediatricians envisage the concept of ACP in general and to what extend do they engage in ACP in their daily practice? (Chapter 4)

1.4 How do parents face the future while caring for a child with a life-limiting condition? (Chapter 5)

\section{To design of a pediatric ACP intervention}

2.1 What are components of a pediatric ACP intervention based on current evidence, underlying theories and stakeholders' perspectives? (Chapter 6)

\section{Evaluation first experiences with the ACP intervention IMPACT}

3.1 What are the characteristics of ACP conversations and related documentation conducted by clinicians using IMPACT? (Chapter 7)

3.2 What are the experiences of clinicians and families regarding ACP conversations based on IMPACT? (Chapter 8)

\section{Major findings of the studies}

\section{Structure, content and theoretical background of ACP interventions using a conversation guide}

The systematic review on interventions to support ACP conversations revealed a structure for ACP conversations consisting of four steps: preparation, initiation, exploration and action. (Chapter 2) Relevant topics in ACP conversations included the patient's perspectives on illness, living well, end-of-life themes, expectations for the future and decision making. A few interventions described their rationale, mainly being behavior theories. Empirical evidence on the effect of the interventions was based on heterogeneous outcome measures. Dyad congruence and preference documentation rates increased in most studies. The studies showed varying effects on knowledge of $\mathrm{ACP}$, decisional conflict, quality of communication and preferences-concordant care. Qualitative research showed that participants appreciate the 
importance and benefits of ACP conversations, yet perceive them as difficult and emotional. Evidence on the translation of explorative information into specific treatment preferences and consequences for care as provided is limited.

\section{Anticipating the future in pediatric palliative care}

A secondary analysis of a qualitative interview study on experiences of clinicians and parents in pediatric palliative care, showed clinicians and parents use different strategies to anticipate the future. (Chapter 3) Three forms of anticipating the future were identified: goal-directed conversations, anticipated care and guidance on the job. In goal-directed conversations, clinicians and parents tried to achieve that the other could align with their point of view regarding future care and treatment. Clinicians mainly discussed advance directives and the preferred place of death. Parents initiated goal-directed conversations about the future to achieve a good life for their child and prevent suffering, to think about family planning, to get consent from clinicians for practical arrangements or to discuss about life-sustaining treatments. Anticipated care means that clinicians or parents organize practical care arrangements in advance, with and without informing each other, such as equipment and medication for the home setting or arrangements for the funeral of the child. Guidance on the job is a form of short-term anticipation. Clinicians guide parents ad hoc through difficult scenarios that were about to happen in the nearby future. Clinicians and parents did not report to engage in early conversations about the future with an explorative character about goals and preferences for future care and treatment.

\section{Engagement and attitude of pediatricians in ACP}

Since care for children with life-limiting conditions is provided by both general pediatricians and pediatric sub specialists in the Netherlands, a survey study among all pediatricians working in six hospitals was performed to identify elements of ACP in their practice. (Chapter 4) Pediatricians $(n=145)$ reported to have discussed at least some ACP topics with parents in their latest case of a deceased child. Topics common to many cases were diagnosis, life expectancy, care goals, the parent's fears and code status. ACP conversations occurred with children in $23 \%$ of cases. The frequency of ACP conversations was insufficient according to $49 \%$ of the respondents. 


\section{Facing the future as parents of a child with a life-limiting condition}

Our research project continued with a qualitative interview study of the perspectives of 20 parents of children with life-limiting conditions towards the future. (Chapter 5) Parents reported to focus on the near future of their child. However, their actions and deeper thoughts showed perspectives towards a further future. Future perspectives initially focused on practical, diseaserelated themes, but more existential elaborations, reflecting underlying life values, were also identified. Parents needed acknowledgement of their challenging situation, care tasks, and expertise as a precondition for sharing their deepest thoughts regarding the future of their child.

\section{Key elements of a pediatric ACP intervention}

Based on the results of the prior research questions, that involved the evaluation of current evidence and stakeholders' perspectives regarding ACP, three areas of attention in pediatric ACP were identified. (Chapter 6) A pediatric ACP intervention needs to have a holistic approach of ACP, pay attention to the voice of the child and stimulate a caring attitude of HCPs towards families. These findings were considered in relation to existing theories on concepts of care, behavior change and coping with illness and bereavement. Intervention materials were developed for each element of ACP: identification, discussion and documentation of values,

goals and preferences for future care and treatment. ${ }^{5}$ An overview of the intervention materials is presented in Table 2 . 
Table 2. Overview of the content of IMPACT

\begin{tabular}{|c|c|c|}
\hline $\begin{array}{l}\text { Element of } \\
\text { ACP }\end{array}$ & IMPACT content & Rationale \\
\hline Identification & $\begin{array}{l}\text { - Fill-in booklet for children } \\
\text { to prepare for the ACP } \\
\text { conversation } \\
\text { - Leaflet for parents to } \\
\text { prepare for the ACP } \\
\text { conversation } \\
\text { - Brochure for HCPs to } \\
\text { educate them about the } \\
\text { concept of ACP } \\
\text { - Preparation card for HCPs to } \\
\text { structure the invitation of } \\
\text { families and create } \\
\text { appropriate circumstances }\end{array}$ & $\begin{array}{l}\text { Information about ACP topics and } \\
\text { preparation in advance supports a } \\
\text { holistic approach. The materials } \\
\text { stimulate to think about medical, } \\
\text { psychological, social and spiritual } \\
\text { perspectives regarding the future in a } \\
\text { person-centered way. Separate } \\
\text { questions about the child's perspectives } \\
\text { stimulate attention to the voice of the } \\
\text { child. }\end{array}$ \\
\hline Discussion & $\begin{array}{l}\text { - Conversation guide for } \\
\text { conversations with parents } \\
\text { - Conversation guide for } \\
\text { conversation with children } \\
\text { and parents } \\
\text { - Training of specific } \\
\text { communication skills: } \\
\text { explore values, respond to } \\
\text { emotions, respond to } \\
\text { stage of change, provide } \\
\text { information, rake } \\
\text { recommendations math a } \\
\text { Pocket guide with } \\
\text { summary of the conversation } \\
\text { guide }\end{array}$ & $\begin{array}{l}\text { The conversation guide addresses topics } \\
\text { that give insight in the families' living } \\
\text { with illness, their values and preferences } \\
\text { regarding future care and treatment. } \\
\text { The guide supports clinicians to address } \\
\text { themes beyond the medical domain. It } \\
\text { includes specific attention to the child's } \\
\text { perspective. There is attention to the } \\
\text { parenting role and it creates space for } \\
\text { acknowledgement of their challenging } \\
\text { context. The training stimulates } \\
\text { clinicians to use communication skills } \\
\text { that support the relationship with } \\
\text { families by a caring attitude, including } \\
\text { response to emotions. }\end{array}$ \\
\hline Documentation & $\begin{array}{l}\text { - Format for documenting the } \\
A C P \text { conversation }\end{array}$ & $\begin{array}{l}\text { The format can be completed by the } \\
\text { family or by the clinician. It summarizes } \\
\text { the conversation content on all different } \\
\text { topics of ACP and gives insight in the } \\
\text { family's perspectives regarding the } \\
\text { future. }\end{array}$ \\
\hline
\end{tabular}

Clinicians and families reported to consider the IMPACT materials as appropriate for ACP for children with life-limiting conditions. 


\section{Characteristics of ACP conversations and related documentation based on IMPACT}

A qualitative analysis of 26 ACP conversation based on IMPACT, identified these conversations have a family-centered content, that gives insight in the families' perspectives on living with illness, quality of live and underlying family values. (Chapter 7) Goals and preferences for future care and treatment were less specified during the conversations. Communication attitudes of clinicians entailed evasive patterns, refraining the conversations from a deeper exploration of the families' values and preferences. These attitudes entailed mixed framing regarding the child's condition, exploration by assumptions and lack of deeper exploration of clues given by children or parents. Documentation patterns differed largely. Some consisted of a very concise summary with a clear conclusion, whereas others were more like a representation of the conversation as a whole, without clear conclusions or definition of next steps.

\section{Experiences of clinicians and families with ACP conversations based on IMPACT}

A qualitative interview study using thematic analysis among 18 clinicians, 32 parents and three children, identified they valued being involved in ACP conversations based on IMPACT. They experienced a stronger relation with each other. Clinicians gained deeper insight in the families' values. Families felt heard and seen in domains outside the medical domain. The conversations were seen as part of an continuing process in which family and clinicians came closer to each other, which supported sharing of future perspectives. Although the participants valued the conversations largely, the perceived added value of the conversation regarding future care and treatment remained limited.

\section{Integrating the outcomes}

The concept of $A C P$

During this research project it turned out that there is an interest in ACP in pediatrics. Both clinicians and families of children with life-limiting conditions value anticipating the future and see the benefits of thinking about future scenarios in advance and being prepared for any changes in the child's condition. A model of pediatric ACP was developed, that integrates the child's and families' expertise on living with illness and living a good life with the expertise of 
clinicians on care and treatment. The use of IMPACT in the pilot study showed that a holistic approach that focusses on the voice of the child and a caring attitude to parents, makes ACP a process that creates a bond between the family and the healthcare team. Families feel acknowledged in their challenging context, making them receptive to share their perspectives regarding the future of their child. These first steps in ACP are a base for further exploration of goals and preferences for future care and treatment, depending on the disease trajectory of the child. In this way, IMPACT is useful in initiating ACP early in disease trajectories without a need for decision making in the moment. Whereas ACP is still often perceived as strategy to discuss treatment limitations, discussing goals of care does not include concrete treatment decisions by definition nor does it have to contain end-of-life decision making.

Although literature about the concept of ACP focusses more and more on clarification of values, goals and preferences for care and treatment in a broader context, instead of on end-of-life decision making ${ }^{5,17}$ studies evaluating ACP experiences among children and families often stay close to an end-of-life oriented approach. ${ }^{3,18-20}$ End-of-life care is an import part of anticipating the future in the context of a life-limiting condition. However, when ACP is started early in disease trajectories a broader focus is needed. This includes a focus on supporting families in achieving good care for their child, including attention to the child's development, family balance, being a good parent during different disease trajectories and how to be able to continue and safe-guard optimal care for the child. Discussing these themes early in disease trajectories can stimulate children and parents in further developing their decision-making roles and being able to stay in control, even when it comes to the end of life of their child. When ACP remains focused on the end of life, opportunities to achieve shared goals of care and treatment earlier and in a way that supports the family to live a meaningful live aligned to their values, will be missed.

An holistic approach of ACP is valued, but experienced as confronting

In the studies conducted in the development phase of this research project, it was identified that in current practice, anticipating the future entails mainly a practical and disease-based approach, where clinicians try to guide families throughout the disease trajectories, while providing high 
quality care in the best interest of the child. This aligns with the primary parental aim when caring for a child with a life-limiting condition, that is focused at controlling symptoms and controlling the disease in the here and now. ${ }^{21,22}$ In some of the ACP conversations guided by IMPACT, it was also observed that questions about the actual treatment or symptoms needed to be addressed first, before any conversations about values and preferences for the future could be explored. This is in line with the theory of representational approach of patient education, which states that clinicians and patients need a shared starting point regarding their illness understanding, before a deeper exploration can occur. ${ }^{23}$ Although it seems more natural for clinicians and families to stay close to disease-related themes, the ACP conversations based on IMPACT showed that a holistic approach of the child and family regarding living with illness is valued and considered relevant when discussing future care and treatment. IMPACT contributes to a holistic family-centered view, which aligns with the definition of ACP and has the potential to function as a strategy to achieve a person-centered approach to care.

At the same time, participants reported that a deeper exploration of the families' narrative on the impact of their child's illness is emotionally confronting for both families and clinicians, as is the disclosure of medical expertise about expectations for the child's future. We identified evasive communication styles among clinicians, especially when it came to sensitive issues such as the child's prognosis, quality of life or end-of-life care.

Emotional distress has been repeatedly identified as a barrier for ACP, mainly by clinicians. ${ }^{24}$ However, experiences of parents indicate that emotional distress should not refrain families and clinicians from ACP. ${ }^{8}$ It is known that parental coping strategies influence their attitude towards loss and their ability to face a future where they could lose their child's life. ${ }^{25,26}$ Parents who focus on preservation of a status quo of their child's condition, have more difficulties to face their child's actual situation and care needs. Parents with the ability to face the loss of their child might be able to anticipate the future in a more comprehensive way. ${ }^{22,25,27}$ Attention to and exploration of the position of the family towards loss, might influence their readiness to participate in ACP and endure deeper confrontations with their (future) loss during the ACP process. It is known that clinicians can interpret emotional distress during conversations as a 
sign of unwillingness or unreadiness of families to discusses sensitive issues. In reaction, clinicians refrain from using clear language and an open conversation regarding prognosis and the end of life. ${ }^{28,29}$ Besides this, research shows clinicians can have feelings of failure when facing disease progression in a child they care for. ${ }^{30}$ This might withhold them from exploring feelings of loss in the family.

In pediatric ACP, clinicians need insight in the coping mechanisms of families with loss to understand the meaning of upcoming emotions during ACP and how they can use communication skills within the ACP conversation to respond to emotions in an adequate way. This will support them to achieve a holistic approach of the conversation with deeper exploration of the family's values and preferences, even when it comes to discussions about ongoing losses. ${ }^{31-33}$ The IMPACT training includes sessions on communications skills relevant in ACP. During the pilot study it was observed in the conversations and reported by participants, that even experienced and trained clinicians still feel difficulties in handling emotions in ACP. This illustrates a need for ongoing training and coaching on the job. When there is an adequate response to emotions in $\mathrm{ACP}$, emotional reactions become valuable sources of information instead of perceived barriers leading to withdrawal from deeper explorations in ACP.

\section{Defining goals of future care and treatment remains challenging}

Whereas the holistic approach was observed in the ACP conversations and valued by the participants in the interview studies, the deduction of values and preferences from patient's narratives and translations of these values and preferences into goals of care, seemed more difficult. A comprehensive summary including goals of care was often lacking in the conversations and participants had difficulties to specify the added value of the conversations regarding goals of future care and treatment. Both clinicians and parents perceived the conversations as valuable, mainly due to feelings of a stronger connection and a multidimensional attention the life of the family. Establishing a trustful relationship and having a holistic attention to the life of the child and family are important elements of ACP. However, when the ACP process does not involve defining goals of care, sooner or later, the expected effect of ACP on preferences concordant care might be limited. In our study, only few clinicians 
took the lead in the conversation to support parents to clarify their preferences and goals of care. In the model of pediatric ACP, as developed during the development phase of this project, attention to the expertise of the family on living with illness and living a good life, needs to be integrated with the expertise of the medical team regarding the appropriateness of care and treatment in specific (future) situations to achieve a shared understanding of goals of care, contributing to the quality of care for the child. The IMPACT materials and clinician training focus on the exploration of the families' narrative to stimulate clinicians to convey an attitude of listening and attention to the perspectives of the family. Clinicians normally tend to have a communication attitude of providing information and directing treatment decisions, which can hinder an open evaluation of the families' perspective. In the pilot study, it was observed that the use of IMPACT stimulated clinicians to focus on the families' perspective as intended. However, IMPACT also intends to include the clinician's expertise in the conversations as illustrated in the model of pediatric ACP. More guidance in the materials and training is needed to support clinicians to integrate the family's perspectives regarding their child's future with their own expertise to achieve a shared understanding of goals of care in the best interest of the child as an outcome of ACP.

In literature, outcomes of ACP conversations often include an advance directive, including emergency care plans and appointment of a personal representative. ${ }^{5,6,34,35}$ These outcomes are more specific and more easily trackable, compared to definition of goals of future care in general. When clinicians are used to approach ACP with a focus on end-of-life decision making, establishing goals of care early in disease trajectories contains challenges. Early in disease trajectories, there might be less need to define goals of care in terms of end-of-life care, yet it is known that parents experience multiple other goals for their child and family during the disease trajectories, that reflect their values. ${ }^{21}$ These contain more overarching aims and encompassing goals, such as to prevent suffering, achieve optimal symptom management and disease treatment, maintaining family balance and create a life worth living for their child. ${ }^{21}$ These aims can be translated to goals of care, that can guide future decision making. In this way, ACP becomes a strategy to prepare families for future decision making, based on their values, instead of focusing on end-of-life decisions in ACP. ${ }^{36}$ In adult literature, value-clarification methods are 
used to facilitate discussions about goals of care and treatment decisions. ${ }^{37}$ Some use a visual analogue scale which can help patients to prioritize health outcomes. ${ }^{38}$ Patients are then invited to share why they made a choice for certain healthcare outcomes. This can reveal underlying values, that can inform future decision-making. The Family-Centered Advance Care Planning intervention, tailored to adolescents and young adults, uses a survey to clarify their values regarding $A C P$ and end-of-life treatment, as a first step of the ACP intervention. ${ }^{39}$ The survey is followed by a session with an ACP conversation and a third session in which a living will can be completed. Although this intervention focuses on end-of-life options mainly, such value clarification methods can be used in early pediatric ACP as well. When striving for an early initiation of ACP in pediatrics, defining goals of care needs a broad approach of exploring topics with children and families relevant in living with illness and ongoing re-evaluation with transition to new care goals over time. ${ }^{40}$ Clinicians need to be educated and supported in identifying patient values and to relate these values to goals of care. Discussing or prioritizing examples of goals of care with children and parents, can support both clinicians and families to get a clearer insight in goals of care based on the families' values and preferences.

\section{The position of the child in ACP is complex}

Where defining goals of future care and treatment was identified as a challenging part of ACP, even with parents, this accounts even more for the involvement of the child in ACP in general. During the development phase and the pilot phase of this research project, it was observed that involvement of the child in ACP is complex, both in research and in practice. Although this research project from the start intended to give the child a central position in all steps, a limited number of children was included in the different sub studies. Nevertheless, the children that were involved showed to be able to reflect on ACP in a comprehensive way. During the pilot phase, few ACP conversations were conducted with children. Clinicians reported to feel less skilled to communicate about ACP with children.

This might have influenced which children they invited to participate in the study. Gate-keeping is a well-known phenomenon in pediatric palliative care research. ${ }^{41}$ In the conversations that actively involved a child, IMPACT showed to contribute to a central position of the child in the 
conversation, which was valued by the children themselves, the parents and clinicians. However, it also raised unexpected questions in some cases regarding death and dying for example. Thus active involvement of the child in ACP requires excellent communications skills from clinicians to respond to difficult and unexpected questions. Besides this, parents need to be able to cope with their child's point of view, that might include confrontational perspectives and preferences, that have not been shared before. In our study, we offered the parents at first the choice whether to involve the child in order not to disrupt any coping strategies of the family. In the Netherlands, children aged 12 to 16 years need to be informed and give consent for their care and treatment, as well as their parents. Children, aged 16 and above, decide for themselves. One could argue the opportunity to participate has to be offered to the child itself, both in research and in practice, from 12 years of age on. When analyzing the ACP conversations in this study, it turned out that when the child was not involved in the conversation, either based on the child's incapacity or the families' preference, only a few parents approached ACP topics explicitly from their perceived child's perspective apart from their own perspectives. Some parents were aware of a coping mechanism, that their wish to keep their child alive as long as possible, might interfere with the child's best interest. They expressed the need for support from clinicians, to help them to safeguard goals of care in the best interest of the child. Other parents were very consistent that they were the most capable decision makers for their child, also when confronted with imminent death of their child.

In literature, studies repeatedly report a lack of involvement of children in ACP. ${ }^{19}$ In general, there are few instruments that support involvement of children in decision making. ${ }^{42}$ Even for children near adulthood, having a central role in managing their care and treatment is complex. Therefore, in pediatrics a need for shared management is emphasized in literature. ${ }^{43}$ Research in oncology with a sample where $40 \%$ of the children were above 12 years of age, showed that depending on the nature of the disease, creating space for a child's decision to forgo treatment is not an option. ${ }^{44}$ Children perceived they did not have a real choice and most felt content with their parents as major decision makers. However, children valued to be informed about their disease and to be involved in minor decisions. 
It is known that parents have many reasons to refrain from talking about death and dying with their child, which might function as a barrier for ACP. ${ }^{45}$ These include both child-related factors, such as disabilities and perceived unwillingness to talk, and parent-related factors, such as perceived inability to talk about end-of-life themes and the intention to protect the child against bad news. ${ }^{45}$ It is known that parental coping strategies can interfere with the voice of the child being heard when it comes to the child's end-of-life. ${ }^{46}$ This is mainly related to parental coping with ongoing losses in their child's life, such as a gradual decline of the child's condition and mental and physical functions. ${ }^{25}$

Beside child-related and parental barriers, including their coping strategies, clinician-related barriers may hinder active involvement of the child in ACP. ${ }^{47}$ These are mostly related to the quality of communication. ${ }^{7}$ Open and age-appropriate communication can support the engagement of young people in ACP. Clinicians might need specific education and training to become more skilled in communicating with children about sensitive isues. ${ }^{24}$

In pediatric ACP, a family-centered approach is needed, that supports attention to the voice of the child and at the same time support the family dynamics, including parental coping strategies. The families' strategy to cope with their situation might contribute to the best interest of the child. On the other hand, some family dynamics might interfere with the child's best interests or preferences. Whereas some authors state that family integrity might be prioritized above the child's best interest ${ }^{48}$ the child's perspective deserves a position in ACP, at least by exploring the family dynamics, decision-making roles and coping mechanisms in relation to the child's best interest. Clinicians' awareness regarding the child's perspectives and best interests and a caring attitude for the family as a whole in ACP might create an opportunity for the child to speak for him or herself, even when this has been difficult before.

\section{Strengths and limitations}

This research project that resulted in the development and first evaluation of IMPACT, was closely connected to daily practice in the care for children with life-limiting conditions. Based on the Framework for the Development and Evaluation of Complex Interventions of the Medical Research Council, this project had a robust and straight-forward study design, which is 
considered as one of its strengths. The development phase integrated evidence from literature, actual perspectives from stakeholders and theoretical backgrounds, leading to a comprehensive rationale for the intervention components. The involvement of stakeholders from the start of the project, created a base for collaboration during subsequent research steps in the project. Participants had different backgrounds, which contributed to the generalizability of the study results and the applicability of the intervention in different contexts. The involvement of local pediatric palliative care teams and the national center of expertise on pediatric palliative care supported ongoing development of the intervention and opportunities for implementation in pediatric practice.

A limitation of the study is the limited involvement of children throughout the research project . Although attention to the voice of the child was identified as an important element in pediatric $A C P$, this turned out to be challenging both in the research context and in clinical practice. Selection bias might be another limitation that influenced the results. Since it is known that barriers to ACP are widespread, participants who are interested and willing to get involved in ACP might represent people with a more receptive attitude towards the concept of ACP, influencing the results in favor of any benefits of ACP.

With a main focus on the development phase of the ACP intervention, other factors important to adequate implementation of the intervention have been understudied. These includes system factors such as finances, human resources, and the acceptability of IMPACT for different subpopulations such as people with a different cultural background, language barriers or intellectual disabilities.

The pilot evaluation of the intervention gave initial insights in the experiences of users of the intervention. The effects of IMPACT regarding important ACP outcomes, such as preferences concordant care, still need to be studied.

\section{Implications for practice}

IMPACT provides a comprehensive toolkit and training to support ACP in the care for children with life-limiting conditions. IMPACT can be used as a starting point for healthcare organizations 
to initiate projects to implement ACP in their context. The holistic nature of the intervention aligns with the current attention to pediatric palliative care and person-centered care. Although in this research project clinicians were the initiators of an ACP process, IMPACT can be used by families as well to initiate an ACP conversation themselves. Empowerment of families is needed to bring this field forward. The availability of IMPACT online for free contributes to its use in daily practice by all stakeholders.

\section{Recommendations for further research}

This research project is to be seen as a first step in the exploration of the uncharted territory of pediatric ACP in the Netherlands. Although key elements of pediatric ACP have been identified and further developed in the context of IMPACT, many questions remain. These questions pertain to the position of the child in the first place. More insight is needed in ways to involve children in ACP and in strategies to elicit their perspectives. Besides this, questions concerning the involvement of clinicians remain. ACP is experienced as a valuable but time consuming approach. This leads to legitimate questions, such as whether all clinicians should be trained in ACP or whether primary responsible physicians should work together with a facilitator with expertise in ACP to be able to provide ACP. Since a continuous relationship between clinicians and families is valued in ACP, an external facilitator who is not involved in the care for the child might not be preferred. A multidisciplinary approach, with a nurse as facilitator and the primary physician attending, might be an interesting topic for further research. Facilitators might play a role in the involvement of less motivated clinicians and advocate for the implementation of ACP. These facilitators could play a role in ongoing training and coaching of other clinicians. Regarding the effectiveness of ACP, questions about relevant outcome parameters remain. More insight is needed in what way ACP can influence actual future care and treatment aligned to the goals and preferences of children and their family. An underlying ethical question is whether ACP should be proved to be effective on certain outcome parameters. A different point of view could be that ACP is by principle the right thing to do, to support a person-centered, holistic approach of care for children with life-limiting conditions. Then it may become less relevant to prove the effectiveness of ACP in experimental research studies. 


\section{Conclusion}

Children with a life-limiting condition, their parents and clinicians feel the need to anticipate the future, although this involves a confrontation with ongoing losses. ACP was experienced as a valuable strategy to anticipate the future when it entails a holistic approach, supports attention to the voice of the child and stimulates an attitude of caring for the family. We developed IMPACT, a pediatric ACP toolkit and clinician training that aims to support identification, sharing and documentation of values, goals and preferences for future care and treatment. During conversations based on IMPACT, sharing families' perspectives on living with illness and living a good life strengthened the relation between clinicians and families, which can contribute to future shared decision making. Defining goals of future care and treatment early in disease trajectories, apart from end-of-life decisions, turned out to be challenging. Evasive communication patterns regarding the child's prognosis and condition and a lack of deeper exploration of concepts as comfort care and quality of life contributed to a limited translation of the family's perspectives into goals and preferences of care and treatment. Recommendations for further research include the development of strategies to support clinicians and families to translate values into goals and preferences for future care and treatment early in disease trajectories and to achieve a central position for the child, either by involving children themselves or by actively searching for the child's perspective as deducted from the perspectives of those who stay the closest to the child.

\section{References}

1. Fraser ALK, Miller M, Hain R, et al. Rising National Prevalence of Life-Limiting Conditions in Children in England. Pediatrics. 2012;129(4):e923-e929.

2. Håkansson Eklund J, Holmström IK, Kumlin T, et al. "Same same or different?" A review of reviews of person-centered and patient-centered care. Patient Educ Couns. 2019;102(1):3-11.

3. Taylor J, Booth A, Beresford B, Phillips B, Wright K, Fraser L. Specialist paediatric palliative care for children and young people with cancer: A mixed methods systematic review. Palliat Med. 2020 Jun; 34(6): 731-775. 
4. Liberman DB, Song E, Radbill LM, Pham PK, Derrington SF. Early introduction of palliative care and advanced care planning for children with complex chronic medical conditions: A pilot study. Child Care Health Dev. 2016;42(3):439-449.

5. Rietjens JAC, Sudore PRL, Connolly M, et al. Review Definition and recommendations for advance care planning: an international consensus supported by the European Association for Palliative Care. Lancet Oncol. 2017;18(9):e543-e551.

6. Myers J, Cosby R, Gzik D, et al. Provider Tools for Advance Care Planning and Goals of Care Discussion: A Systematic Review. Am J Hosp Palliat Med. 2018;35(8):1123-1132.

7. Hughes B, O'Brien MR, Flynn A, Knighting K. The engagement of young people in their own advance care planning process: A systematic narrative synthesis. Palliat Med. 2018;32(7):1147-1166.

8. Lotz JD, Daxer M, Jox RJ, Borasio GD, Führer M. " Hope for the best, prepare for the worst ": A qualitative interview study on parents ' needs and fears in pediatric advance care planning. Palliat Med. 2016;31(8):764-771.

9. Needle JS, Peden-McAlpine C, Liaschenko J, et al. "Can you tell me why you made that choice?": A qualitative study of the influences on treatment decisions in advance care planning among adolescents and young adults undergoing bone marrow transplant. Palliat Med. 2020;34(3):281290.

10. Durall A, Zurakowski D, Wolfe J. Barriers to conducting advance care discussions for children with life-threatening conditions. Pediatrics. 2012;129(4):e975-e982.

11. Lotz JD, Jox RJ, Borasio GD, Fuhrer M. Pediatric advance care planning from the perspective of health care professionals: A qualitative interview study. Palliat Med. 2015;29(3):212-222.

12. Liberman DB, Pham PK, Nager AL. Pediatric Advance Directives: Parents' Knowledge, Experience, and Preferences. Pediatrics. 2014;134(2):E436-E443.

13. Lotz JD, Jox RJ, Borasio GD, Führer M. Pediatric advance care planning: A systematic review. Pediatrics. 2013;131(3):e873-e880. 
14. Zadeh S, Pao M, Wiener L. Opening end-of-life discussions: how to introduce Voicing My CHOiCES $^{\mathrm{TM}}$, an advance care planning guide for adolescents and young adults. Palliat Support Care. 2015;13(3):591-599.

15. Lyon ME, Jacobs S, Briggs L, Cheng YI, Wang J. Family-centered advance care planning for teens with cancer. JAMA Pediatr. 2013;167(5):460-467.

16. Lyon ME, D'Angelo L, Dallas $\mathrm{RH}$, et al. A randomized clinical trial of adolescents with HIV/AIDS: pediatric advance care planning. AIDS Care - Psychol Socio-Medical Asp AIDS/HIV. 2017;29(10):1287-1296.

17. Sudore RL, Fried TR. Redefining the "Planning" in Advance Care Planning: Preparing for End-of-Life Decision Making. Ann Intern Med. 2010 Aug 17; 153(4): 256-261.

18. Orkin J, Beaune L, Moore C, et al. Toward an understanding of advance care planning in children with medical complexity. Pediatrics. 2020;145(3):e20192241

19. Hein K, Knochel K, Zaimovic V, et al. Identifying key elements for paediatric advance care planning with parents, healthcare providers and stakeholders: A qualitative study. Palliat Med. 2020;34(3):300-308.

20. DeCourcey DD, Silverman M, Oladunjoye A, Wolfe J. Advance Care Planning and Parent-Reported End-of-Life Outcomes in Children, Adolescents, and Young Adults With Complex Chronic Conditions. Crit Care Med. 2019;47(1):101-108.

21. Verberne LM, Kars MC, Meeteren AYNS, et al. Aims and tasks in parental caregiving for children receiving palliative care at home: a qualitative study. Eur J Pediatr. 2017;176(3):343-354.

22. Verberne LM, Kars MC, Meeteren AYNS, et al. Parental experiences and coping strategies when caring for a child receiving paediatric palliative care: a qualitative study. Published online 2019;178:10751085.

23. Donovan HS, Ward SE, Song MK, Heidrich SM, Gunnarsdottir S, Phillips CM. An update on the representational approach to patient education. J Nurs Scholarsh. 2007;39(3):259-265.

24. Durall A, Zurakowski D, Wolfe J. Barriers to conducting advance care discussions for children with life-threatening conditions. Pediatrics. 2012;129(4):e975-82. 
25. Kars M, Grypdocnk M, De Korte-Verhoef $M$, et al. Parental experience at the end-of-life in children with cancer: 'preservation' and 'letting go' in relation to loss. Support Care Cancer. 2011;19:27-35.

26. Kars MC, Grypdonck MHF, Beishuizen A, Meijer-van Den Bergh EMM, Van Delden JJM. Factors influencing parental readiness to let their child with cancer die. Pediatr Blood Cancer. 2010;54(7):1000-1008.

27. Fahner JC, Thölking TW, Rietjens JAC, van der Heide A, van Delden JJM, Kars MC. Towards advance care planning in pediatrics: a qualitative study on envisioning the future as parents of a seriously ill child. Eur J Pediatr. 2020 Mar 19. Online ahead of print.

28. Marsac ML, Kindler C, Weiss D, Ragsdale L. Let's talk about it: Supporting family communication during end-of-life care of pediatric patients. J Palliat Med. 2018;21(6):862-878.

29. Lee BM, Rosenberg AR. Don't let perfect be the enemy of good: How to improve prognostic communication in pediatric oncology. Cancer. 2017;123(20):3879-3881.

30. Weiner JS, Cole SA. Three Principles to Improve Clinician Communication for Advance Care Planning: Overcoming Emotional, Cognitive, and Skill Barriers. J Palliat Med. 2004;7(6):817-827.

31. Ekberg S, Danby S, Herbert A, Bradford NK, Yates P. Affording opportunities to discuss deterioration in paediatric palliative care consultations: a conversation analytic study. BMJ Support Palliat Care. Published online 2017:bmjspcare-2016-001130.

32. Back AL, Fromme EK, Meier DE. Training Clinicians with Communication Skills Needed to Match Medical Treatments to Patient Values. J Am Geriatr Soc. 2019;67(S2):S435-S441.

33. Van Vliet LM, Epstein AS. Current state of the art and science of patient-clinician communication in progressive disease: Patients' need to know and need to feel known. J Clin Oncol. 2014;32(31):3474-3478.

34. Brinkman-stoppelenburg A, Rietjens JAC, Heide A Van Der. The effects of advance care planning on end-of-life care: A systematic review. Palliat Med. 2016;28(8):1000-1025.

35. Loeffen EAH, Tissing WJE, Schuiling-Otten MA, De Kruiff CC, Kremer LCM, Verhagen AAE. Individualised advance care planning in children with life-limiting conditions. Arch Dis Child. 2018;103(5):480-485. 
36. Sudore RL, Fried TR. Redefining the "Planning" in Advance Care Planning: Preparing for End-of-Life Decision Making. Ann Intern Med. 2010;153(4):256-261.

37. Witteman HO, Scherer LD, Gavaruzzi T, et al. Design Features of Explicit Values Clarification Methods: A Systematic Review. Med Decis Mak. 2015;36(4):453-471.

38. Stegmann ME, Festen S, Brandenbarg D, et al. Using the Outcome Prioritization Tool (OPT) to assess the preferences of older patients in clinical decision-making: A review. Maturitas. 2019;128(July):49-52.

39. Lyon ME, Garvie P a, Briggs L, He J, McCarter R, D'Angelo L. Development, feasibility, and acceptability of the Family/Adolescent-Centered (FACE) Advance Care Planning intervention for adolescents with HIV. J Palliat Med. 2009;12(4):363-372.

40. Hill DL, Miller V, Walter JK, et al. Regoaling: A conceptual model of how parents of children with serious illness change medical care goals. BMC Palliat Care. 2014;13(1):1-8.

41. Kars MC, Van Thiel GJMW, Van Der Graaf R, Moors M, De Graeff A, Van Delden JJM. A systematic review of reasons for gatekeeping in palliative care research. Palliat Med. 2016;30(6):533-548.

42. Feenstra $B$, Boland $L$, Lawson $M L$, et al. Interventions to support children's engagement in healthrelated decisions: a systematic review. BMC Pediatr. 2014;14.

43. Lozano $P$, Houtrow A. Supporting self-management in children and adolescents with complex chronic conditions. Pediatrics. 2018;141(March 2018):S233-S241.

44. Coyne I, Amory A, Kiernan G, Gibson F. Children's participation in shared decision-making: Children, adolescents, parents and healthcare professionals' perspectives and experiences. Eur J Oncol Nurs. 2014;18(3):273-280.

45. van der Geest IMM, van den Heuvel-Eibrink MM, van Vliet LM, et al. Talking about Death with Children with Incurable Cancer: Perspectives from Parents. J Pediatr. 2015;167(6):1320-1326.

46. Kars MC, Grypdonck MH, de Bock LC, van Delden JJ. The parents' ability to attend to the "voice of their child" with incurable cancer during the palliative phase. Heal Psychol. 2015;34(4):446-452. 
47. Yotani N, Kizawa Y, Shintaku H. Differences between Pediatricians and Internists in Advance Care Planning for Adolescents with Cancer. J Pediatr. 2017;182:356-362.

48. Lindemann H. Why families matter. Pediatrics. 2014;134(October):S97-S103. 


\section{Appendices}

Implementing Pediatric Advance Care Planning Toolkit

Additional tables Systematic review (Chapter 2)

Topic lists Anticipating the future (Chapter 3)

Questionnaire Survey study (Chapter 4)

Topic lists Developmental phase (Chapter 5 and 6)

Topic lists Pilot phase (Chapter 6,7 and 8)

List of Publications 


\section{IMplementing Pediatric Advance Care Planning Toolkit}

Information leaflet for professionals

Information leaflet for parents

Information leaflet for children

Preparation card for professionals

Conversation guide for conversations with parents and children

Conversation guide for conversations with parents

Documentation format for children

Documentation format for parents

Pocket guide for professionals 


\section{Information leaflet for professionals}

\section{Advance Care Planning (ACP) in Pediatrics}

Explanations and suggestions for professionals
Introduction

This document provides you with an explanation of what Advance Care Planning (ACP) is and also offers you suggestions for conducting ACP discussions with children and parents. ACP discussions are different fror conducting ACP discussions with children and parents. ons explore how a child and his/her parents approach life and what they consider to be important. The purpose of this exploration is to better align decisions about the child's care and treatment with the values, preferences and needs of the child and family. NB: where the term parents is used, it can also mean parent or guardian(s)

NB: the role of the child depends on hisher age and develop

Summary of key points related to ACP

Key points for Advance Care Planning in Paediatric Medicine:

- ACP is a communicative process that enables children and parents to formulate thei values, goals and preferences for future care and treatment and to discuss these goals and preferences with caregivers and relatives.

- This process can be adjusted according to the child and parents' willingness to talk about the future.

- ACP is relevant for all children with a life-limiting or life-threatening condition and can happen at any time. The need and motivation for ACP increases when the

condition of the child deteriorates or as the end of life approaches.

- The child's primary treating physician is involved in the ACP process

- The fundamental guestion in ACP is what is truly important to this child, to these parents and to this family?

- The next question is: what does care and treatment that is aligned to the values ane preferences of the child and family look like

- During ACP discussions, experiences with illness, values, hopes, fears and worries are explored at medical, psychosocial and spiritual levels.

- ACP discussions explore the child's preferences and aims regarding future care and

treatment, as well as those of the parents and family.

- The health care professional can share his/her perspectives regarding the child's

future as necessary

- The health care professional can provide information about additional care and

treatment options as necessary,

- During an ACP discussion, the health care professional will ask who makes decision: about the care and treatment of the child and how the child is to be involved.

- Preferably, the child participates in conversations in a manner that is appropriate for his/her age and competence.

- If the child is unable to particioate in the discussions, parents and caregivers consciously describe the child's perspective and interests.

- A summary of ACP discussions is documented in the medical record. Specifled

treatment directives are shared with other care professionals involved.

- Aims and preferences for care and treatment may change over time.

ACP discussions can therefore be held repeatedly and care directives can always be amended or revised. 
What is Advance Care Planning? Advance Care Planning (ACP) is a process that enables children and parents to formulate thei values, goals and preferences for future care and treatment and to discuss these goals and preferences with caregivers and relatives. ACP encourages children and parents to reflect on the significance and consequences of a serious illness. ACP deals with the needs of children and parents in physical, psychological, social and spiritual terms.

Care professionals talk to children and parents about their expectations regarding the child's development and the progress of the disease. The caregiver asks what the child and parents see as truly important in the child's care and treatment now and in the future $A C P$ invites children with a seri to discuss any care $p$ efe them and to revise them if necessary. During this process, the child is involved in a way that is appropriate for his/her age and level of development.

Why is ACP important?

Every child and family has his/her own unique needs. Every child goes through their own process of development. For a child with a lifelimiting or life-threatening condition, ongoing development is closely linked to the course of the disease and to the corresponding care and treatment required. Care and treatment should match the needs, values, preferences and aims of the child and family and should contribute to a 'good' life for the child.

In ACP conversations, children and parents are asked how they perceive the future and what they consider to be important in regarding care and treatment. This is assessed by asking them questions about their values, preferences and goals with a view to the future. In this process. the individual child's needs, desires and wishes form the starting-point of the discussions.

These discussions are necessary to reinforce the autonomy of the child and parents and to promote shared decision-making.
Thus, they form the basis for decisions about the child's future care and treatment. By particiess, care professionals de perspectives of the an illness, living a good life and the quality of life.

ACP can contribute to proper alignment of care and treatment with the family's preferences. It also prepares families for situations that may arise in the future and thus reduces uncertainty and fear if a critical situation occurs. $A C P$ can prevent unexpected acute hospitaACP can prevent unexpected acure hospitalizations and invasive procedures. In addition, careful documentation of an ACP conversation provides clarity in acute situations for care professionals who are not familiar with the child.

\section{What are the aims of ACP}

\section{discussions?}

The aim of ACP is to ensure that the child receives care and treatment that corresponds to his/her values, goals and preferences and to those of the family. The following principles form the foundation of an $\mathrm{ACP}$ conversation and help achieve this aim

1.) Exploration of the perspectives of the child with illness and about the future.

1.2) Support for the child and parents in identifying their values and sharing these values with other care professionals.

1.3) Exploration and documentation of the aims of the child and parents for future care an treatment.

behandeling verkennen en documenteren

1.4) Support for the child and parents when translating preferences into goals about future care and treatment.

1.5) Help parents articulate and define their role as parents and decision-makers for the child.

1.6) Keep the child's perspective central, whether this be in direct communication with the child or via the parents or significant others.
For whom is ACP relevant? $A C P$ is relevant for all children with a lifelimiting or life-threatening condition. In principle $A C P$ can be conducted at any age and at any time during the course of an illness. The necessity and focus increase when the condition of the child deteriorates due to his/her illness.

The questions below can assist in identifying children with a serious illness who might be eligible for $A C P$ :

- Would I be surprised if the child were to die from this illness?

- Would I be surprised if the child were to die from this condition before reaching adulthood - Would I be surprised if the child wore to die from this condition within the next twelve months?

If the answer to any one of the above question is 'no' ACP might be relevant for the child, the family and health care professionals involved.

When are ACP discussions held? ACP discussions preferably take place during a stable stage of the disease process and not during a time of crisis. This gives the people involved space to reflect on the conversation and to think about it without immediately needing to make decisions.

Who initiates an ACP discussion? In principle, everyone can initiate an ACP conversation colv on their In practice, children and parents inition the care profesionals to take the initiative. Care professionals involved can be pediatricins, generalprative s, psychologis social workers or child life specialists.

Preferably, the child's primary medical care provider should be involved in the discussion This ensures congruence between the ACP discussions and the child's future care and treatment. The conversation can be led by the primary physician him/herself or by another healthcare provider who is able to effectively facilitate ACP discussions. Involving various disciplines or areas of expertise in the discussions can lead to a broader, more nuanced perspective. For this reason, the child, family or primary physician can consider inviting other relevant healthcare professionals to the discussion.

How does an ACP discussion affect the child, parent and professional? Talking about the future with children who have a serious illness can be difficult. These conversations confront the child, parents
care providers with the child's possible deterioration, and this can be emotionally challenging. However, parents want open and honest information. They want to be involved in the decision-making process regarding their child's care and treatment. After an ACP conversation is initiated, parents often feel more enabled to think about various options and to talk about them. These discussions help families maintain hope and find meaning hurip a child's illness. Healthcare professionals need these conversations so they con harmo these conctir medich the child's and hisher parents. By discovering optimally aligned to the family's needs.

\section{How do I prepare for an ACP} discussion?

An ACP discussion requires preparation.

It is necessary to be well informed about the condition of the child, the care and treatment options, his/her expected prognosis and who is involved in the child's care. It is important to consider the child's current and prospective developmental levels. It is also important to think about the ACP topics prior to the discussion: be well versed in the issues that will be addressed and practice how to discuss these topics. The IMPACT conerstion Eude and topics. The assist in this preparation.

How do I prepare parents for an ACP discussion?

ACP discussions should be a regular aspect of medical care. Given the special nature of these discussions, they should preferably be planned separately from other consultations. Make sure to reserve sufficient time to conduct an ACP conversation. 
Parents and children are not always ready for an ACP conversation. When inviting a child and parents to an $A C P$ conversation, their needs are central If parents or children are reluctent to en in $A C P$ converstion, cluty reasons in order to leave the possbly having the discussion at a later time.

The preparation chart of IMPACT contains instructions and sample phrases for inviting parents to an ACP discussion. The following points form part of preparation:

Ask if the child will be present during the ACP discussion.

- Book a separate appointment for the ACP discussion and set aside enough of time for this meeting (at least 60 minutes)

- Before the appointment, ask the parents if they would like other care professionals (family doctor, nurse, home care professional) or family members to participate as well. - Before the appointment, give the parents a copy of the information letter about the discussion.

\section{How is an ACP discussion}

\section{structured?}

An ACP discussion is primarily an explorative conversation or a listening conversation; during the conversation the child's and parents' perspectives are the central focus. The child and parents have the opportunity to tell about how they live with an illness, what they consider to be important in the child's care and treetment why they consider these things importments well as their hopes and worries. Goals of case and if necessory concrete treas. and, if necessayy concre the determined together with the care profession During the converstion, the care professional may provide additional information about prognosis and different options for care and treatment. This information can pertain to eith the broader process of care and treatment or specific treatment options, such as the insertion of a PEG tube, ventilator support or ICU-admission.

An ACP discussion is structured around four steps. The IMPACT conversation guide lays out the topics for each step with sample phrases.
The IMPACT conversation guide is not meant to be used as a questionnaire Rather it should help support and structure the dirogue. It will aways be necessary to adapt the conversation to the individual children and their parents and to specific situations.

The four steps of an ACP conversation:

\begin{tabular}{|ll|} 
Step I Introduction & $\begin{array}{l}\text { Introduction to the } \\
\text { discussion } \\
\text { Aim of the discussion }\end{array}$ \\
\hline Step 2 Assesment & $\begin{array}{l}\text { Child } \\
\text { Illness } \\
\text { Parenting } \\
\text { Future } \\
\text { Care and treatment }\end{array}$ \\
\hline Step 3 Decision making & $\begin{array}{l}\text { Role of decision makers } \\
\text { Goals of care } \\
\text { Documentation }\end{array}$ \\
\hline Step 4 Conclusion & $\begin{array}{l}\text { Summary } \\
\text { Other issues } \\
\text { Follow-up }\end{array}$ \\
&
\end{tabular}

The discussion should form one coherent whole. It's possible that all the steps cannot be discussed during one meeting because some topics require more elaboration or because th child or parents need more time. If this is the case, the different steps can be divided over several conversations. Not all discussion topics may be relevant for every child. Therefore, agreement with the child and parents should be repeatedly assessed during the conversation.

A subsequent conversation about future care can be arranged at the conclusion of the ACP conversation. It is important for ACP discussions

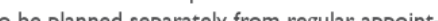
ments in order to undeline their overathing chars in order the und onally dranis for che che why its imp for the child and parents, this is know take place so they can properly prepare.
It takes time to determine the preferences and aims for care and treatment. Preferences and aims can also change over time. As the child's illness or condition changes, the nature of $A C P$ directives can also chase The directives an also chinge The the nassions should be held frequenty: the timing and freof the child's illness.

What is the role of the child in ACP? Ideally, the child will participate in the discussions, depending on his/her age and level of development Before and ACP appointment, the child and parents are asked whether or not the child will be present. In addition, the parents are asked to talk to their child about the planned discussion.

The IMPACT conversation guide provides suggestions for asking the right questions with children and teenagers. Questions used with children should ars be adapted to their and level of development.

If a child is too young or has a developmental disability and cannot express his/her wishes and preferences, the parents can explore the ACP topics with the child's perspective and best interests in mind

\section{How is an ACP discussion}

\section{documented?}

A summary of the ACP conversation is documented in the medical records at the conclusion of the process. The IMPACT documentation form can be used to structure the report it contains a summary of the conversation and describes the care and treatment objectives.

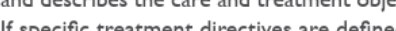
they will also be documented on the included in the dodical records according and the prod the mer the relevant care insto to Care Care and treatment directives must be obvous and clear to all care professionals involved. Discuss with the parents whether external healthcare professionals will also receive a copy of the documentation.

Parents receive a copy of the ACP documentation in the medical record. In addition, they will receive their own form to fill in with their personal summary of the conversation, which they can reflect upon at home.the conversation and to be able to reflect

on this at home.

What communication skills are helpful in ACP discussions?

$A C P$ is a communicative process in which the care provider primarily takes the role of the listener. Questions about what the child and parents consider important are the central focus of the conversation. This requires probing and open questions. Adapt the questions to the child's and parents' responses. Summarise what the child or parents are saying and clarify where necessary. Acknowledge and explore emotions. Name the emotions and do not react to them with factual information.

I can see how this is making you sad/angry/worried. Please tell me more about what is making you feel like this.

Use silence during the conversation; let there be times of silence. Give open and honest information rather than false reassurances. And remember, don't give more information than seems to be needed. Do not use the computer during the discussion. If you want to take notes, please do so on the discussion form. Always maintain eye contact with the child and parents.

If child or parents don't seem to be open to discussing certain topics, explore the reasons for this reluctance.

You don't seem to want to talk about this today. That's okay, you don't need to. Can you help me understand why you prefer not to tolk about this? What do rou think may help rou to think about the?

I know that it is hard to talk to about this, and I would like to see if I can help you to become clearer about what exactly is worrying you about the future. Can you tell me more about that?

When some questions or topics are difficult or emotional for parents, the 'wish/worry/ wonder'-approach may be helpful. 
I also wish that things keep going well for

your child, but l am afraid that we may not

hings turn out to be

different and so, I am wondering if we can

discuss ... together.

To clarify the relevance of looking ahead for the parents, it can be helpful to talk about 'what-if' scenarios.

At the moment, your daughter's airway problem are under control, but what if she gets a serious respiratory tract infection in the coming winter season? What do you think would be important for her then?

If the child is not present during the meeting try to focus on the child's perspective.

How do you think your child feels about this? What is important to him ther ot the moment?

Go through the discussion on your own;

think about what parents may say and how you thould react

How do I apply ACP in my daily activities?

The aim is for ACP to become part of all

standard care. Create an overview of children in

the population you serve who might be eligible for an ACP discussion. Approach the parents

of these children for a special appointment. An unexpected hospitalization, a major operation or an urgent treatment decision may be good reasons to arrange for an $\mathrm{ACP}$ discussion with parents, even if there was no previous need for such a conversation. At the previous need for it is necessery to consider of ACP discussions cis is acssions practice.
Colofon:

IMPACT, $\odot 2019$

Implementing Pediatric Advance Care Planning Toolkit

IMPACT is the result of a collaboration between the UMC Utreche,

the Erasmus MC and the Knowledge Center for Child Palliative Care; it was developed with the cooperation of children, parents, and professionals working in childcare and children's hospitals.

Contact:impact-studie@umcutrecht.nl

The development of this product was financed by The Netherlands Organisation for Health Research and Development.

Design: Design \& producties, UMC Utrecht 


\section{Information leaflet for parents}

\section{$\stackrel{9}{\mathrm{O}} \mathrm{CO}$ \\ Talking together \\ about care \& treatment}

\section{What do you consider important for your child?}

A conversation about your child's care and treatment

O

It can be difficult to look ahead, especially

if it means considering situations where

your child's health may deteriorate. But is important to do this in time. If you have a clear idea about your wishes and preferences, we can take them into account in your child's care and treatment plan. This way, you won't have to think about these preferences and wishes for the first time during moments of acute care. We hope this will put you and your child at ease and give you more control.

What happens during the conversation? During this conversation you can talk with your child's attending doctor or nurse about how you look at your child's future. You can also talk about what you consider important for your child's care and treatment. In this folder you'll find a series of questions to help you prepare for the conversation.

\section{Who will be present during the} conversation?

You child's treating doctor or nurse will be present for the conversation. As parents,

you may invite someone to join you if you want. Is your you can legally make decisions for your child. Your child is welcome to participate in the conversation if he/she wishes and if you think this is alright. Is your child older than 12 but younger than 16 ? According to the law, your child has a right to participate in the conversation and to make decisions about his/her care and treatment together with you.

Is your child 16 or older? Then your child can legally make his/her own decisions and can therefore have the conversation with the attending doctor or nurse either with or without you present.
Your child has a serious illness or condition.

This is why we've invited you for a conversation; we would like to know what you consider to be the best care and treatment options for your child. You can read more about the conversation in this folder as well as how you can prepare for the conversation.

Why is this conversation necessary?

Your child is currently receiving care or treatment for a serious illness or condition. It is important that your child can continue to develop as well as possible. This is why we'd like to hear what you think is important for your child. Not just in the present, but also in the future in case your child's condition deteriorates or improves. This way we can work together to provide the best care for your child.

Are there things that worry you? Is there a chance your child may die from his/her illness? Are there things you absolutely do or do not want for your child? You can talk about these topics during the conversation.

What happens after the conversation?

The attending doctor or nurse will make a summary of the conversation. This summary will be kept in your child's medical file. You will also receive a form to take home; here you can record any agreements you reached during the conversation. Did you write down something that is not in the medical file summary? Then you should make another appointment with the doctor or nurse to ensure that the agreements are clear to you both.

What if your child's situation changes?

What if your child's situation changes? Or what if you change your mind about what you think is good for your child? You can always ask for another conversation with your child's attending doctor or nurse.

How can you prepare for the conversation?

You'll be talking to you child's attending doctor or nurse about what you consider important for your child's care and treatment. The following series of questions can help you prepare for this conversation. 
"What is your child like?"

What does your child like?

What does your child strongly dislike?

What makes your child happy?

What is important to your child?

Is your child afraid of anything? If so, what?

What does your child's illness mean to your child, yourself and your family?"

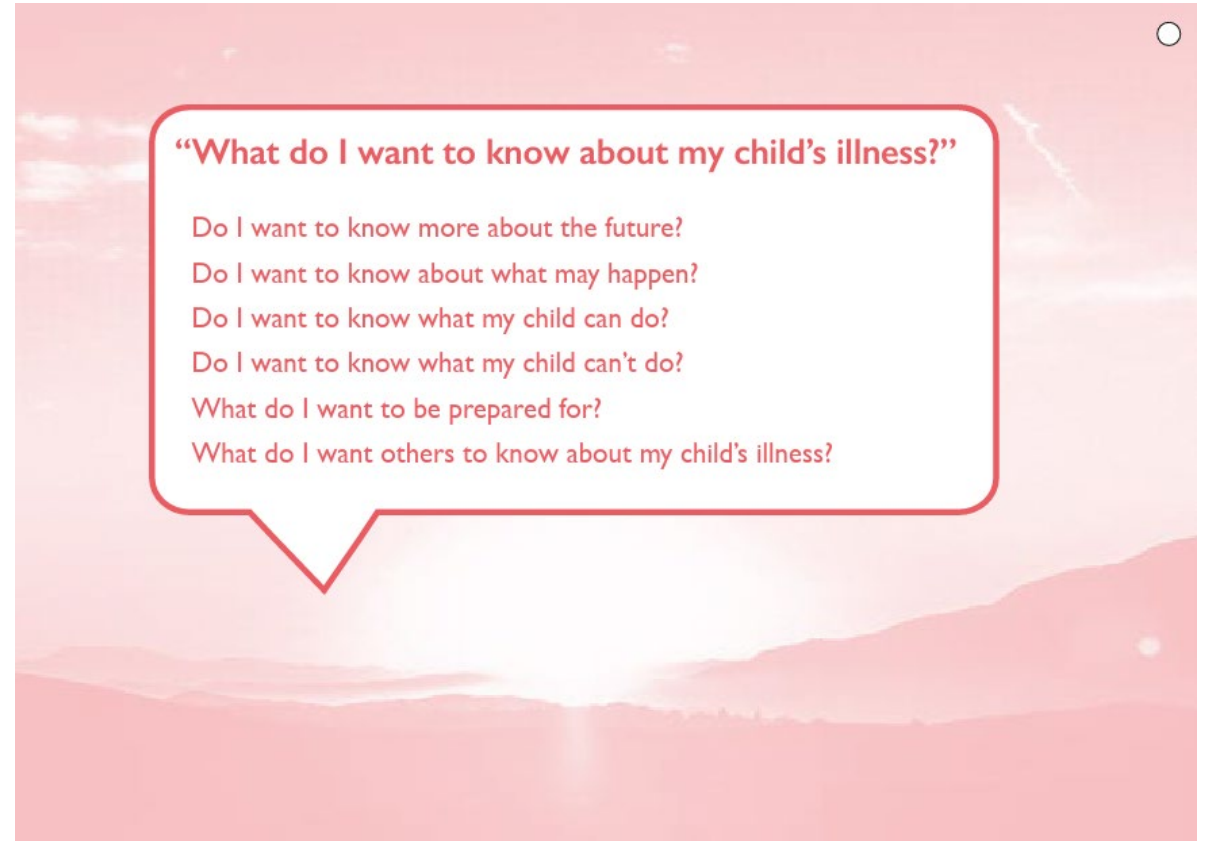

O

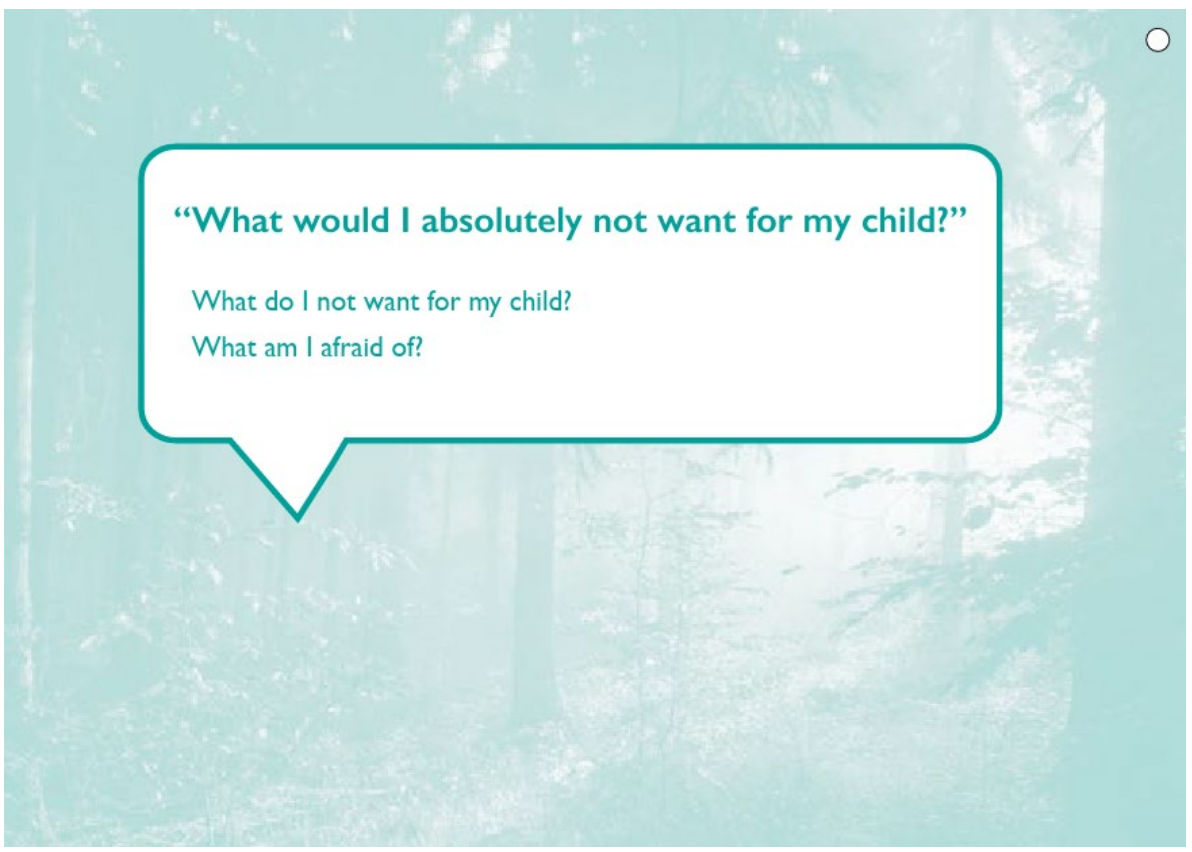

"What do I wish for my child?"

What do I think is a good life for my child?

What do I want to achieve for my child? 
"What sort of parent do I want to be for my child?"

What do I give my child in life?

What do I want to do for my child?
"What do I consider important in the care and treatment of my child?"

What would I like to achieve with the care and treatment of my child?

What do doctors and nurses need to know about the care and treatment of my child?
Colofon

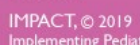

Knowledge Center for Child Palliative Cirecht, the Erasmus MC and the cooperation of chilc.
children's hospitals.
Implementing Pediatic Adrance Care Planning Toolkit IMPACT i s the result
of a collaboration between the UMC Utrecht the Erasmus MC and the

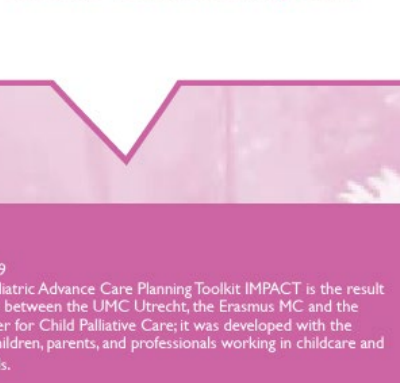

Contact: impact-studie@umcutrecht.nl

The development of this product was financed by The Netherlands Organisotion

Design: Design \& producties, UMC Utrecht 


\section{Information leaflet for children}

○

\section{Irpact \\ Talking together
about care \& treatment}

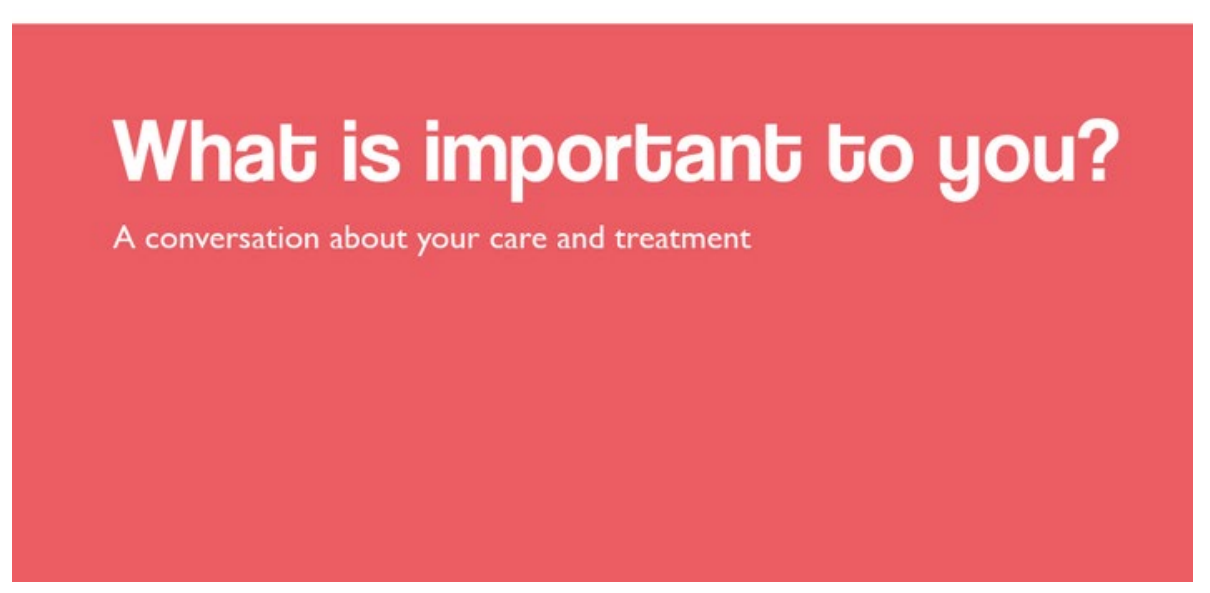

We'd like to invite you for a talk. We want to know what you think is important. So you can receive the care that suits you best.

Why have this talk?

We've invited you to have this conversation because you have a serious illness.

Even though you may not feel really sick. We want to do things that you like, that are right for

you. This is why we want to get to know you better. For instance, what are your hobbies?

What make you happy, and what do you think is silly or stupid? What do you want, both now and in the future? If we know more about these topics, we can take them into account to

makesure that the care and treatment you get is right for you.

Why think about later?

Do you ever ask yourself what your future will be like? Do you wonder if you'll experience pain or feel worn out as a result of your illness? Do you sometimes worry about whether or not you'll be around in the future? You can always discuss these things with your doctor or nurse. They can help you. And they're good listeners. Isn't that great?!

O

Who will you talk to?

If you come for the conversation,

you'll be talking with your own doctor

or nurse. If you'd like, you parents or

caregivers are also welcome to join

the conversation. Would you like to

invite someone else? Someone you

trust? That's fine, too.

And afterwards?

Your doctor or nurse will takes

notes during the conversation. You're

welcome to write things down, too.

For instance, the agreements you make

with your doctor or nurse. We'll keep

all these agreements in your medical

file. So you don't forget them. So we

don't forget them either.
Forget to say something?

Maybe when you're leaving the hospital after the conversation you suddenly think: "I forgot to mention something!" Or perhaps you think of a question or something you'd like to say once you're home. You're welcome to make a new appointment with your doctor or nurse to talk about these topics. You can do this at any time.
Some practice questions

$\sqrt{ }$ (n)

Do you want to practice for the conversation? Feel free to read the following questions and write down your answers. Handy to take with you to your appointment!

What do you like to do, or 'who are you'? What would you like other people to know about you?

What makes you happy?

What do you like to do at the weekend?

Who do you really like? Or, who is really important to you?

What do you really dislike? 
O

"Do you sometimes think about the future?"

$\sqrt{ }$

Are there things you'd really like to do?

Are tra

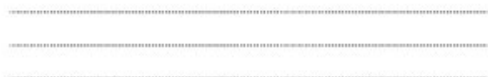

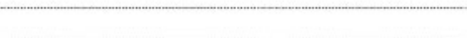

What do you hope for?

What would you like to do later in your life?
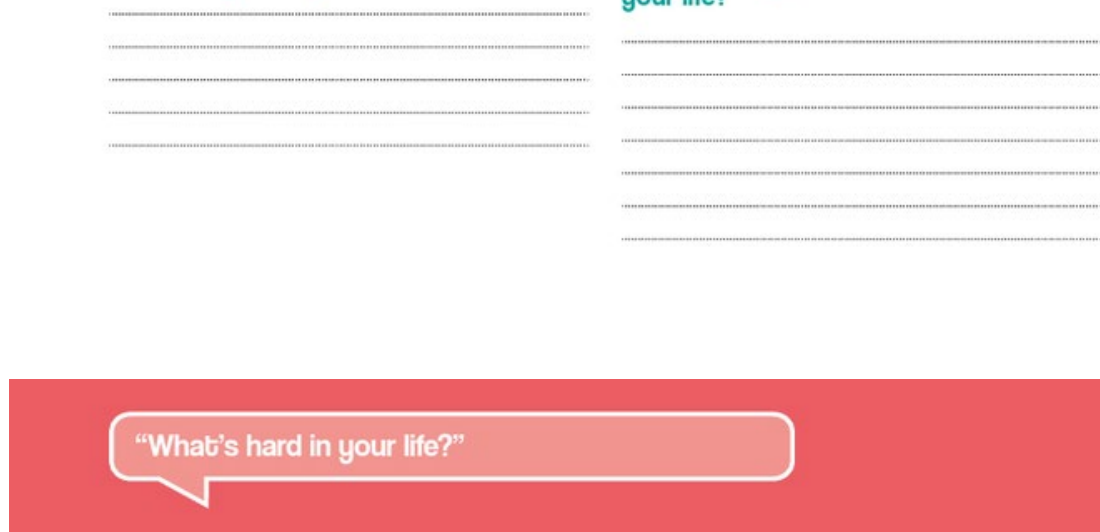

O

What does make things difficult in your life?

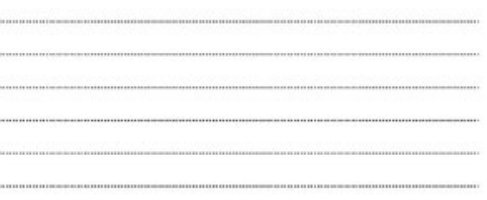

Is there anything that worries you or makes you scared?

Is there anything you really don't want?

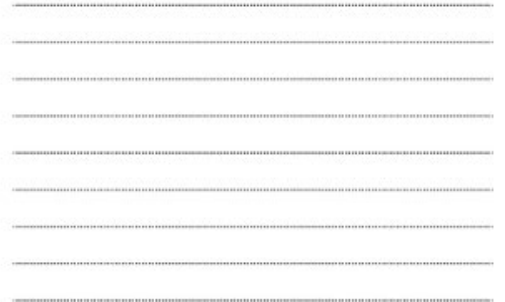

How do you imagine your life will be en you're older?

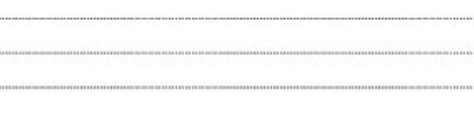

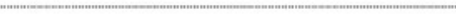
$-0$

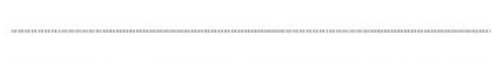

O

"What do you want to know about your illness?"

$\checkmark$

Do you want to know about how your illness may develop?

Do you have any questions about pain or discomfort?

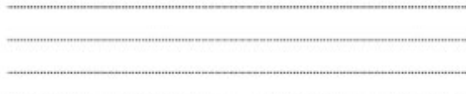

Do you want to know what you may or may not be able to do in the future?

die from your illness?

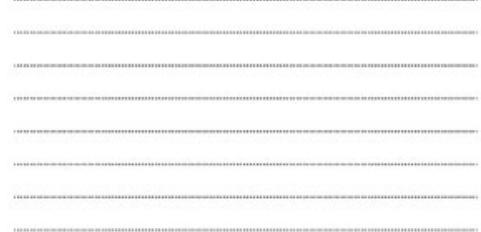

\section{Do you want to know if you can}

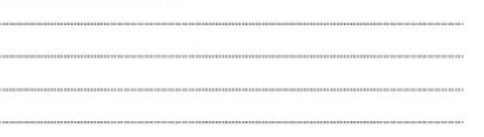

(1)
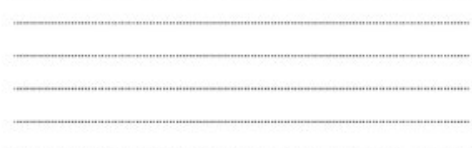

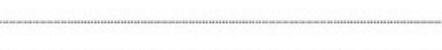

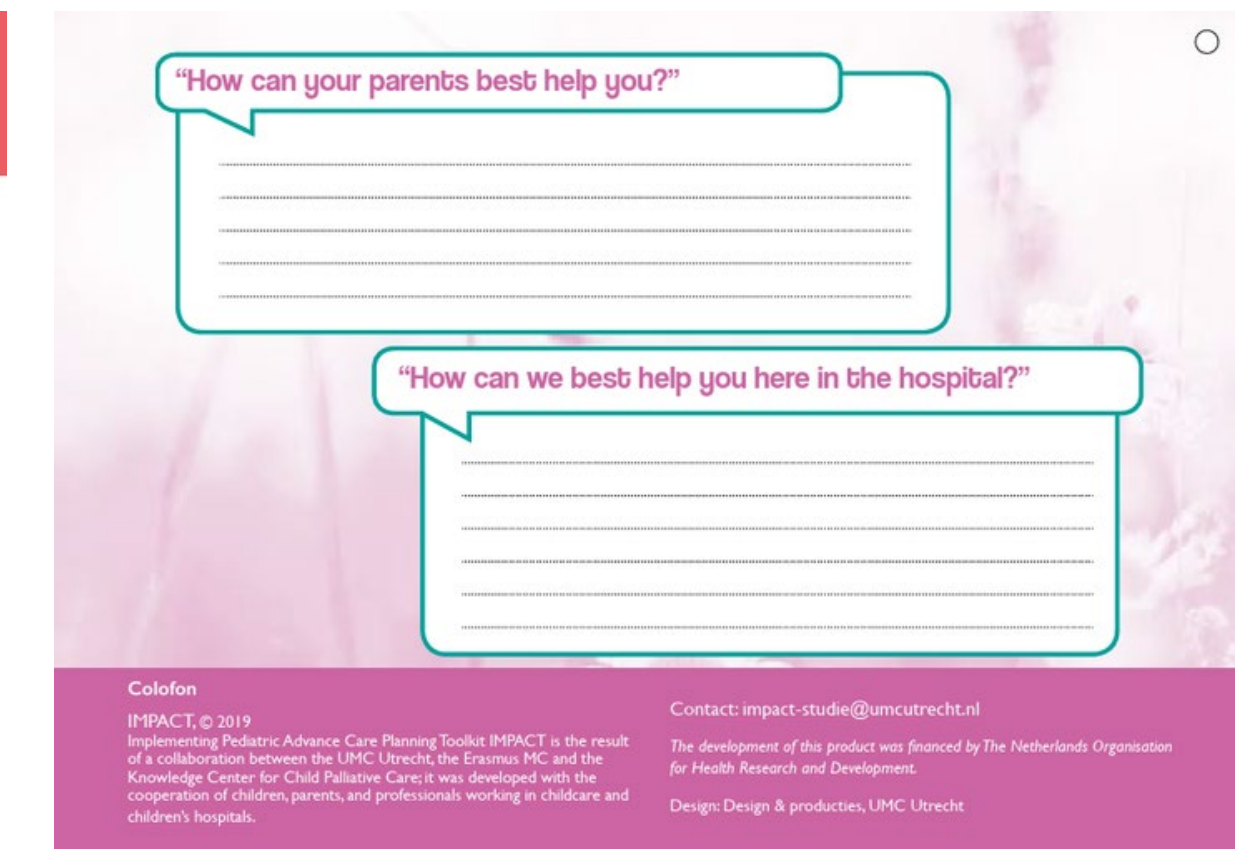




\section{Preparation card professionals}

Preparatory card for professionals:

\section{inviting families for an $\mathrm{ACP}$ conversation}

$$
\begin{aligned}
& \text { Coloton } \\
& \text { IMACACT, } 20 \text { 20 }
\end{aligned}
$$

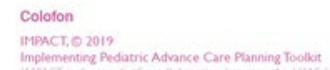

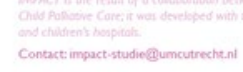

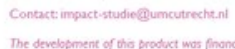

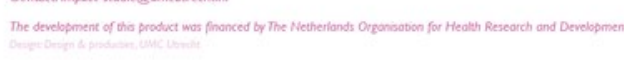

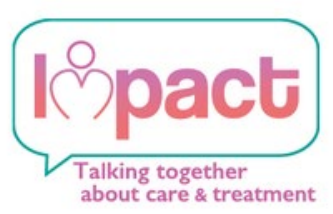

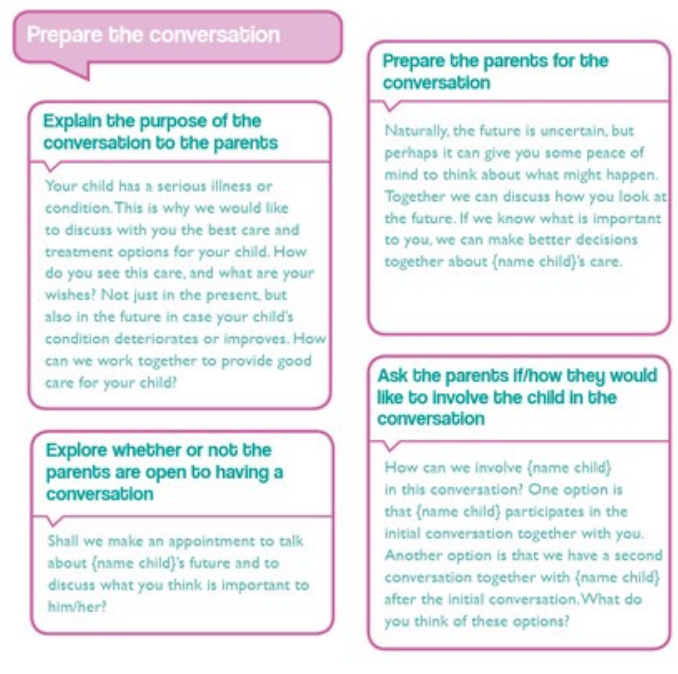

Discuss who will be present during the comversation

Is there anyone elise you would like to

invite te the converation? Perhaps?
crusted family member or friend?

a hestetheare provider who plays an

Suggest that the parents make a separate appointment and that
they reserve enough time (roughty 60 minutes)

Let's plan this converastion separacely

reserve extra time for thit converastion
to we have adequate time to talk about

what you thinki is important in regards to
(name child)s care.

Give the parents the information

letter

In the information letter you can read

more about what you
the conversation. 


\section{Conversation guide children and parents}

Conversation guide for professionals:

\section{conversation with child and parents}
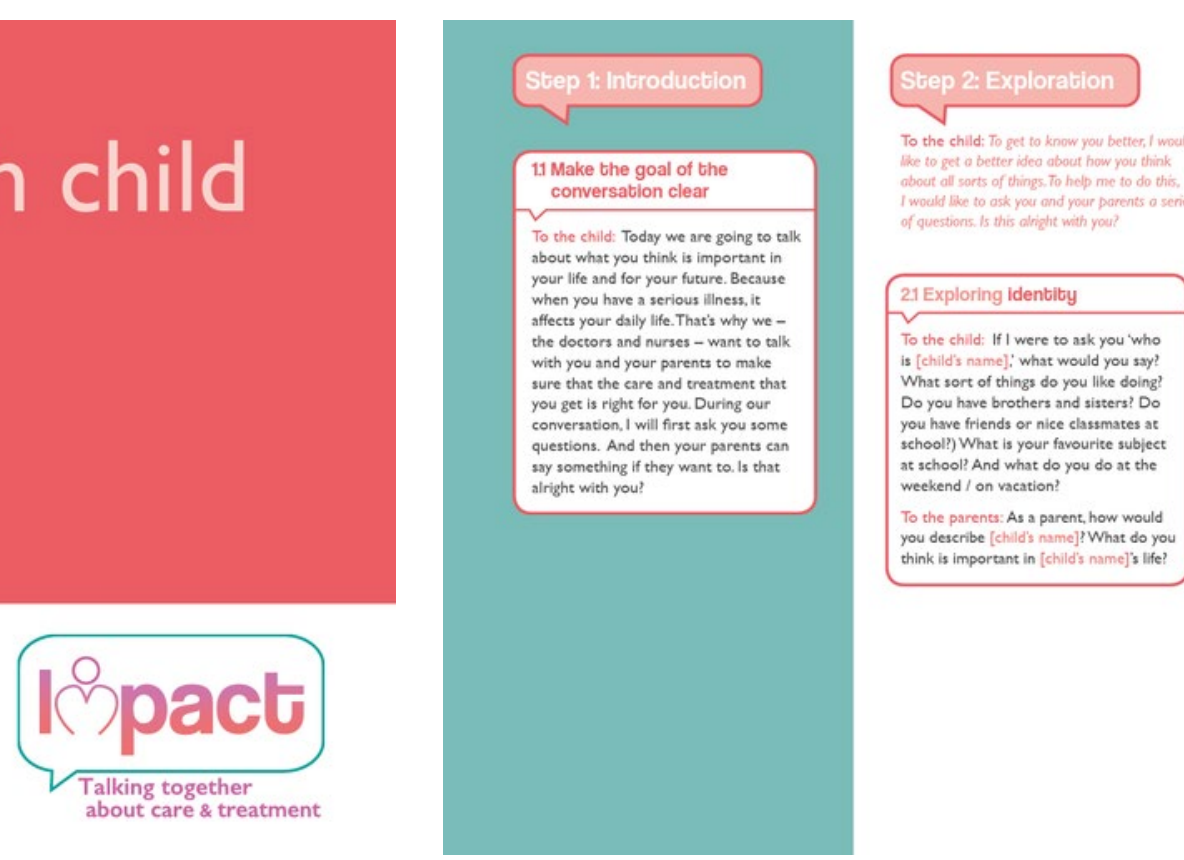

Talking together
about care \& treatment

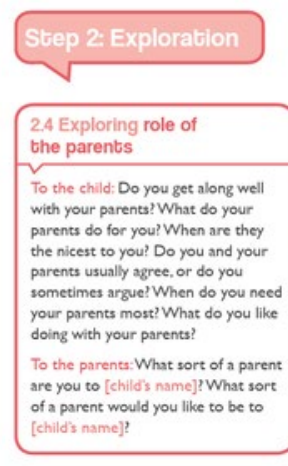

2.5 Exploring views on life To the child: What do you do when
you want to be comforted? Do you speak to someone or go to a spectial ever go to church or to the mosque? Do you like it there

To the parentes: As parenss, do you What makes you feel supported in

\begin{tabular}{|c|}
\hline $\begin{array}{l}2.6 \text { Exploring fears and worries about } \\
\text { the future }\end{array}$ \\
\hline $\begin{array}{l}\text { To the child: Do you worry about things that } \\
\text { could happen in the future' What are you affald } \\
\text { of Do you ever get angry? }\end{array}$ \\
\hline 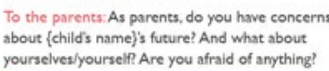 \\
\hline $\begin{array}{l}\text { 2.7 Further information about } \\
\text { expectations for the future } \\
\text { (if necessary) }\end{array}$ \\
\hline 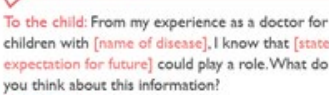 \\
\hline $\begin{array}{l}\text { To the parents: As parents, what are your } \\
\text { thoughts about chis? }\end{array}$ \\
\hline $\begin{array}{l}28 \text { Exploring goals and preferences } \\
\text { for care }\end{array}$ \\
\hline 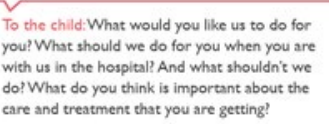 \\
\hline $\begin{array}{l}\text { To the parents in your opinion, as parents. } \\
\text { what is the goal of the care and treatement of } \\
\text { [child's name]? }\end{array}$ \\
\hline
\end{tabular}

\begin{tabular}{|c|}
\hline $\begin{array}{l}\text { Exploring goals and preferences for care } \\
\text { at differing stages of litness (if necessary) }\end{array}$ \\
\hline 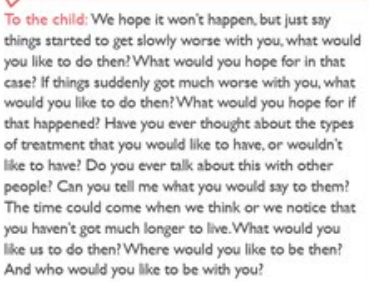 \\
\hline 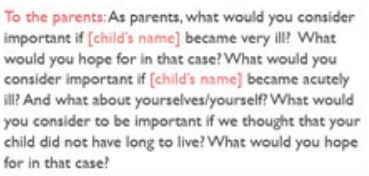 \\
\hline 210 Summary of exploration \\
\hline 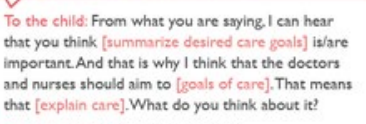 \\
\hline To the parents:And you, as parents? \\
\hline
\end{tabular}
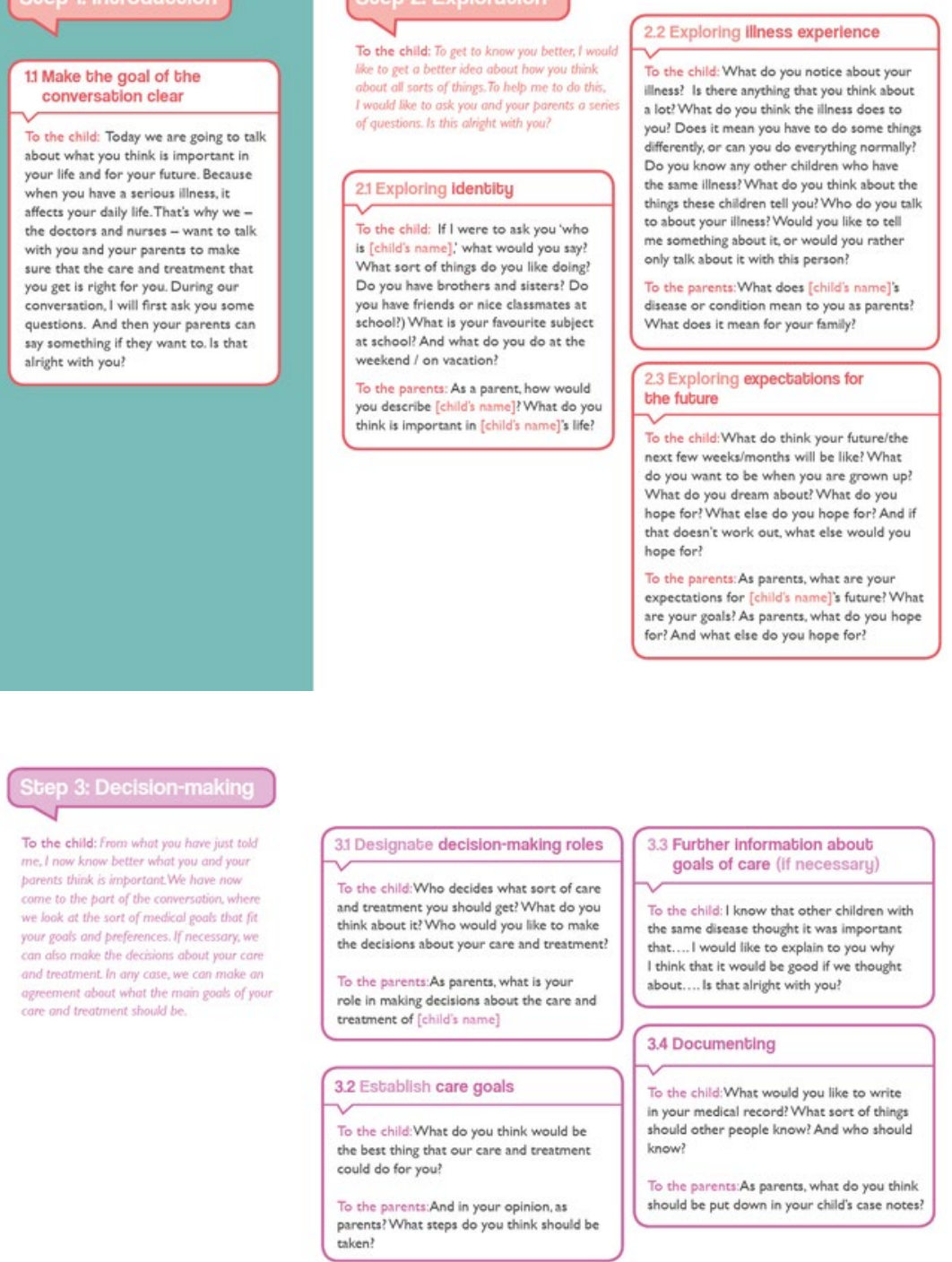


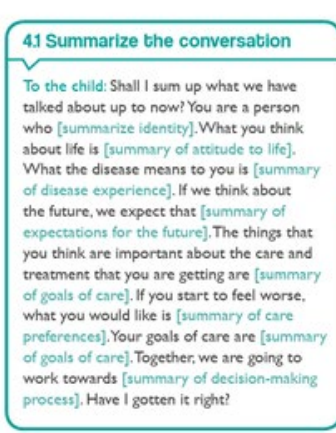

4.2 Enquire about other subjects
To the child: is there anything else you would
like to tell me or to ask me?
To the parensals there anyching else you
would like to discuss?

Notes

Coloton:

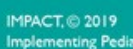

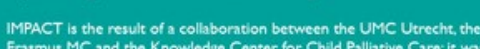

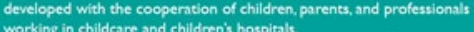
corke

Contact impact-sudule@umcurecechen.

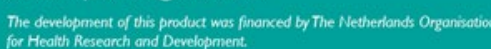

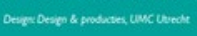




\section{Conversation guide parents}

Conversation guide for professionals:

\section{conversation with parents}
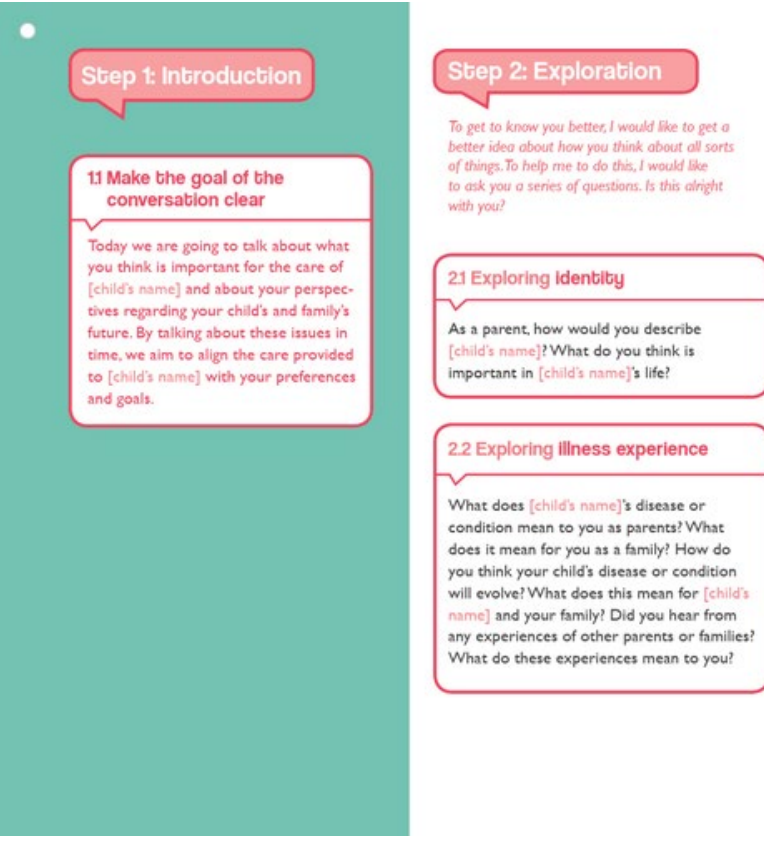

2.3 Exploring quallty of life

How does a good day for [child's name] looks ike? What do you consider importan anyching you do want to achieve for anyching you dof
[childs name]?

\begin{tabular}{|l|}
21 Exploring Identity \\
$\begin{array}{l}\text { As a parenct how would you describe } \\
\text { [childs namele What do you chink is } \\
\text { important in [childs namels slife? }\end{array}$ \\
\hline
\end{tabular}

\section{Exploring illiness experience}

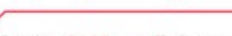

What doest (childs nimme) 's ditease or does it mean for you as a tamily? How do you think your child's disense or condition

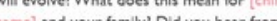
any experiences of other preness or tamilies, What do these experiences mean to you

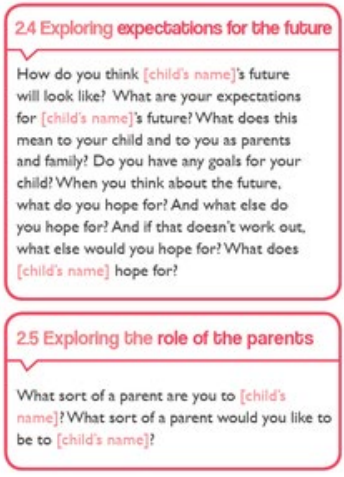

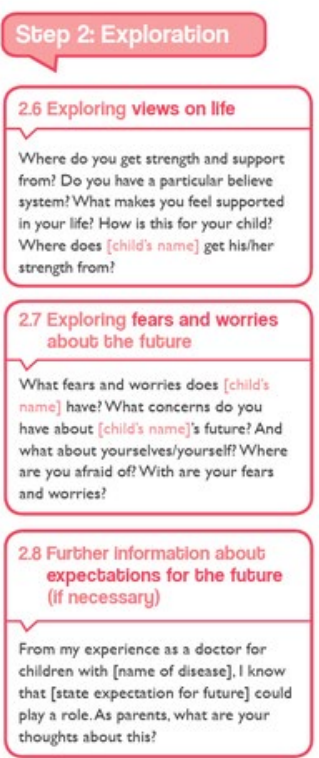

\section{Step 3: Decision-making}

From what you hove just told me, I now know better what you think

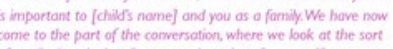

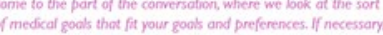

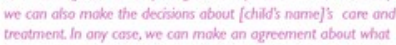
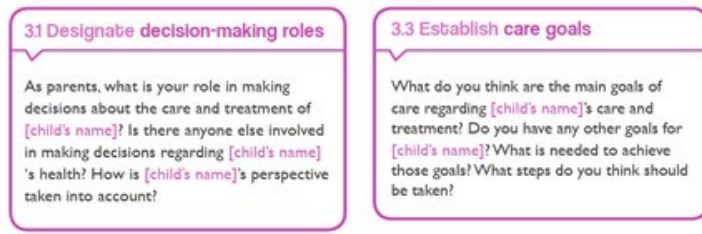

We hope it won't happen, but just tay chings tatred to get slowly worse with [chlld's
namej), what would you hope for? What would you consider important fif childs namej beca. me slowly more ill What would you consider
important if child's namel became acurecy What do you chink abous invasive treastmentes What would you consider to be important if we thought that your child did not have long sol live? What would you hope for in that case Where do you think (chilas names would lite

\section{From what you are saying, can hear chat you}

important for [nasam kind]. And that is why

Tthink that the doctors and nurses shoul

aim to [gools of are]. That means shat
[explain care]. What do you chink about it?

\begin{tabular}{|c|}
\hline $\begin{array}{l}\text { 3.2 Further information about } \\
\text { goals of care (if necessary) }\end{array}$ \\
\hline $\begin{array}{l}\text { I know that other children with the same } \\
\text { disease or their parense thought tit was } \\
\text { important that...I would like to explain to } \\
\text { you why I think that it would be good if we } \\
\text { thought about... Is that alright with you? }\end{array}$ \\
\hline
\end{tabular}




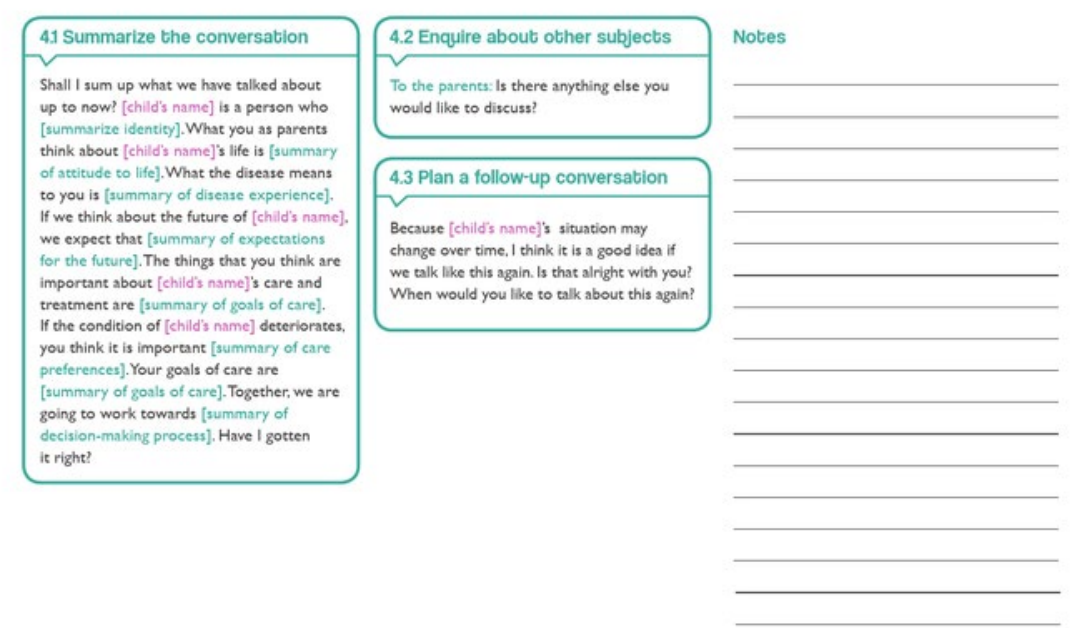




\section{Documentation format children}

Form for care and treatment wishes - child

\section{On _ _ _ We discussed my future and we talked about \\ what is important to me in terms of my health care. The following \\ people were present during the discussion: \\ We talked about:}

Iam someone who...

For my parents and for $m y$

family, this illness means. .

My expectations for the

future are...

For the situation right

now, I think that it is

important that..

The aims of my care and

treatment are. .
If my health gets worse, it

will be important that...

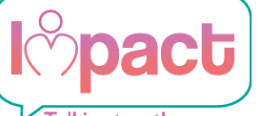

Talking together
about care \& treatment
We agreed to these

specific treatments. .

\begin{tabular}{|l|l|}
\hline specific treatments... & \\
\hline $\begin{array}{l}\text { Our next discussion } \\
\text { meeting will be on... }\end{array}$ & \\
\hline
\end{tabular}

Notes

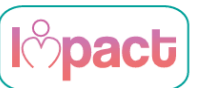

Colofon:

IMPACT, $\odot 2019$
Implementing PediaticA

IMPACT is the result of a collaboration between the UMC Utrecht, the Erasmus MC and the Knowledge Cente-
for Child Palliative Care it was developed with the cooperation of children, parents, and profiessionals working in

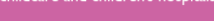

Contact: impact-studie@umcutrecht.ni

The development of this product was financed dy The Netherands Organisation for Heath Research and Development

Design: Design \& producties, unc Uurech 


\section{Documentation format parents}

\section{Form for care and treatment wishes - parents}

What is important to us?

This form is about
On we discussed my our child's future and we
The following people were present during the discussion:
We talked about:

Our child is someone

who..

For our child this illness

means. .

\section{For us as parents and fo \\ the family, this illness}

means...

As parents, our

expectations for the

future are...

For the situation right

now, we think that it is

important that. .

The aims of care and

treatment are.
If our child's health gets

worse, it will be importan

that. .

We agreed to these

specific treatments. ..

\begin{tabular}{l|l}
\hline specific treatments... & \\
\hline $\begin{array}{l}\text { Our next discussion } \\
\text { meeting will be on... }\end{array}$ & \\
\hline
\end{tabular}

Notes

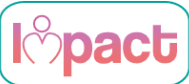

Colofon:

IMPACT, 92019
Implementing Pediatric Advance Care Planning Toolkit

IMPACT is the result of a collaboration between the UMC Utrecht the Errsmus MC and the Knowledge Center
for Child Palliative Care: it was developed with the cooperation of children, parents, and professionals working in

chilcare and children's hospital.

Contact: Impact-studie@umcutrechenl

The development of this product was financed by The Netherands Organisation for Heath Research and Development

Design: Design \& producties, UmC Urrecht 


\section{Pocket Guide}

\section{Irspact \\ Talking together
about care \& treatment}

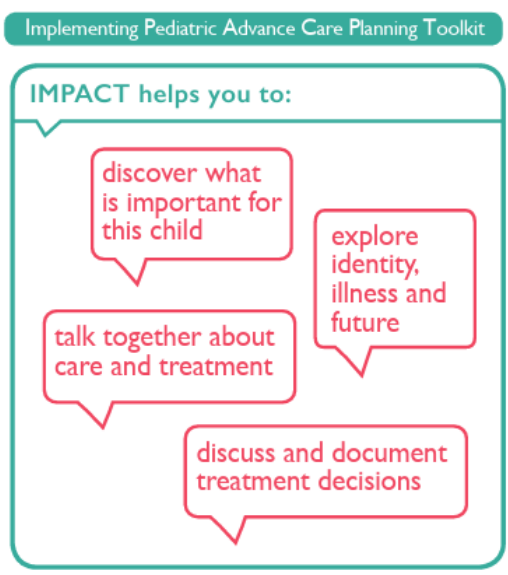

\section{Step t Introduction}

- Discover what is important for this child in regards to

- Are the child and parents ready to talk about this topic?

\section{Gap 2: Exploration}

Identity: Who is this child?

Illness: What does this illness mean for the

child and the family?

Future: What do the child and the parents

expect to happen in the future?

Parenting: How do the parents and child

Parend to support each other?

Belief system: What philosophy of life do the

child and parents have?

Expectations for the future: What do the

child and parents hope for?

Fears and worries. What are the child and

Preferences for care: What do the child and parents consider important in regards to care Petreatment?

Deterioration. What do the child and parents consider important if the child's health should
deteriorate?

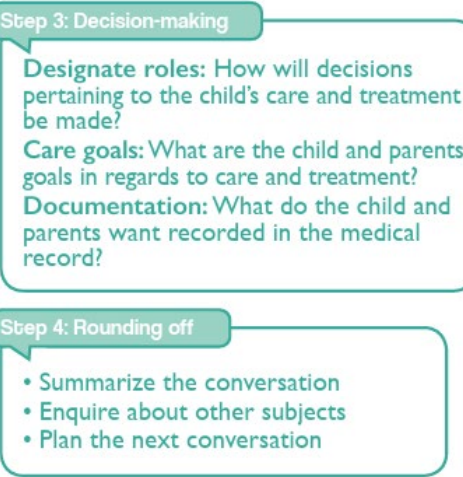

Parallel to step 2 exploration: If necessary, use medical expertise to provide supplennentary information in regards to expectations for the future

Parallel to step 3 decision-making: if necessary, use medical expertise to provide suppicmicitary information about expectations for the future
Colofon

IMPACT, ๑ 2019

Implementing Pediatric Advance Care Planning Toolkit

IMPACT is the result of a collaboration between the

UMC Utrecht, the Erasmus MC and the Knowledge

Center for Child Palliative Care; it was developed with

the cooperation of chidren, parents, and professionals

Contact: impact-studie@umcutrecht.ni

The development of this product was financed by The Netherlands

The development of this product was financed by The
Organisation for Health Research and Development.

Design Design a producties, UMC Utrecht 


\section{Additional tables Systematic review}

Table A1. Adapted risk of bias assessment tool for observational studies

Table A2. Risk of Bias Assessment Trials, Cochrane Risk of Bias Tool

Table A3. Risk of Bias Assessment Observational studies: Adapted risk of bias assessment tool

Table A4. Mixed-method studies, risk of bias assessment quantitative part

Table A5. Mixed-method studies, assessment of quality of reporting qualitative part, COREQ

Table A6. Qualitative studies, assessment of quality of reporting, COREQ

Table A7. Evidence from qualitative studies 


\title{
Table A1. Adapted risk of bias assessment tool for observational studies
}

\author{
Adapted from: The Cochrane Risk of Bias Assessment Tool ${ }^{1}$ \\ High risk: Criteria for low risk not (sufficiently) met for that category \\ Unclear risk: Insufficient information to permit judgment of 'Low risk' or 'High risk'
}

Risk category

Selection process of study population

\section{Comparability of compared groups (controlled studies or in time)}

\section{Criteria for 'low risk'}

-Adequate (representative of the target population), clear, objective definition of inclusion- and exclusion criteria

-The study groups should be clearly defined (exposed versus non-exposed), and at least age and sex should be described in detail.

When two groups are compared:

-both groups are comparable at the start of the study, in particular on variables that are important for the outcome measures (eg. age, sex, health status/ prognosis, education level, religion). If no, these variables are corrected for in the analyses.

-Apart from the intervention, the groups should have been treated similarly throughout the study.

-The determinant (ACP interview) was protocolized, well-defined.

-The determinant should be performed in the same way for all participants -It should be clearly defined when, by whom, and under what circumstances the intervention took place.

-The outcome measures are objective and the criteria well defined. If possible, the tools should be validated and measured according to a standardized protocol.

Any one of the following:

-No missing outcome data;

-Reasons for missing outcome data unlikely to be related to true outcome (for survival data, censoring unlikely to be introducing bias);

-Missing outcome data balanced in numbers across intervention groups, with similar reasons for missing data across groups;

-For dichotomous outcome data, the proportion of missing outcomes compared with observed event risk not enough to have a clinically relevant impact on the intervention effect estimate;

-For continuous outcome data, plausible effect size (difference in means or standardized difference in means) among missing outcomes not enough to have a clinically relevant impact on observed effect size;

-Missing data have been imputed using appropriate methods.

Article states that the confounders most important for the outcome measures were taken into account and define the confounders, eg. time/ health status for pretest-posttest studies

Any of the following:

-The study protocol is available and all of the study's pre-specified (primary and secondary) outcomes that are of interest in the review have been reported in the pre-specified way;

-The study protocol is not available but it is clear that the published reports include all expected outcomes, including those that were pre-specified (convincing text of this nature may be uncommon). 
Table A2. Risk of Bias Assessment Trials, Cochrane Risk of Bias Tool ${ }^{1}$

\begin{tabular}{|c|c|c|c|c|c|c|c|}
\hline & $\begin{array}{c}\text { Random } \\
\text { sequence } \\
\text { generation }\end{array}$ & $\begin{array}{c}\text { Allocation } \\
\text { concealment }\end{array}$ & $\begin{array}{l}\text { Blinding of } \\
\text { participants }\end{array}$ & $\begin{array}{l}\text { Blinding of } \\
\text { outcome } \\
\text { assessment }\end{array}$ & $\begin{array}{l}\text { Incomplete } \\
\text { outcome data }\end{array}$ & $\begin{array}{l}\text { Selective } \\
\text { reporting }\end{array}$ & $\begin{array}{l}\text { Total } \\
\text { score }\end{array}$ \\
\hline $\mathrm{Au} 2012^{2}$ & $?$ & $?$ & - & + & + & - & 2 \\
\hline Briggs $2004^{3}$ & - & - & - & $?$ & + & $?$ & 1 \\
\hline Chan $2010^{4}$ & - & - & - & + & - & - & 1 \\
\hline Dallas $2016^{5}$ & + & $?$ & - & + & + & + & 4 \\
\hline Fischer $2015^{6}$ & + & + & - & + & - & - & 4 \\
\hline Hilgeman $2014^{7}$ & + & $?$ & - & + & + & $?$ & 3 \\
\hline Kirchhoff $2010^{8}$ & + & + & - & $?$ & - & - & 2 \\
\hline Kirchhoff $2012^{9}$ & + & + & - & + & - & - & 3 \\
\hline Lakin $2017^{10}$ & - & - & - & + & $?$ & + & 2 \\
\hline Lyon $2009^{11}$ & + & + & - & - & + & - & 3 \\
\hline Lyon $2009^{12}$ & + & + & - & - & + & + & 4 \\
\hline Lyon $2010^{13}$ & + & + & - & - & + & + & 4 \\
\hline Lyon $2011^{14}$ & + & + & - & - & + & - & 3 \\
\hline Lyon $2013^{15}$ & + & $?$ & - & - & + & + & 3 \\
\hline Lyon $2014^{16}$ & + & $?$ & - & $?$ & + & + & 3 \\
\hline Lyon $2017^{17}$ & + & $?$ & - & + & + & + & 4 \\
\hline Reinke $2017^{18}$ & + & $?$ & - & - & $?$ & + & 2 \\
\hline Schmitten $2014^{19}$ & - & - & - & - & - & - & 0 \\
\hline Schwartz $2002^{20}$ & + & + & - & $?$ & + & $?$ & 3 \\
\hline
\end{tabular}




\begin{tabular}{|c|c|c|c|c|c|c|c|}
\hline Song $2005^{21}$ & $?$ & $?$ & - & - & + & $?$ & 1 \\
\hline Song $2010^{22}$ & + & + & - & + & + & $?$ & 4 \\
\hline Song $2015^{23}$ & + & + & - & + & $?$ & + & 4 \\
\hline Song $2016^{24}$ & + & + & - & + & $?$ & + & 4 \\
\hline Stein $2013^{25}$ & + & + & - & + & - & ? & 3 \\
\hline
\end{tabular}


Table A3. Risk of Bias Assessment Observational studies: Adapted risk of bias assessment tool

\begin{tabular}{|c|c|c|c|c|c|c|c|c|}
\hline & $\begin{array}{c}\text { Selection } \\
\text { process of } \\
\text { study } \\
\text { population }\end{array}$ & $\begin{array}{c}\text { Comparability } \\
\text { of compared } \\
\text { groups }\end{array}$ & $\begin{array}{l}\text { Standardized } \\
\text { protocol for } \\
\text { the ACP } \\
\text { intervention }\end{array}$ & $\begin{array}{l}\text { Standardized } \\
\text { protocol for } \\
\text { measuring the } \\
\text { outcome }\end{array}$ & $\begin{array}{l}\text { Missing data } \\
\text { with regard to } \\
\text { inclusion or } \\
\text { follow-up or } \\
\text { incomplete } \\
\text { outcome data }\end{array}$ & $\begin{array}{l}\text { Adjustment for } \\
\text { confounders }\end{array}$ & $\begin{array}{l}\text { Selective } \\
\text { outcome } \\
\text { reporting }\end{array}$ & $\begin{array}{l}\text { Total } \\
\text { score }\end{array}$ \\
\hline Boettcher $2014^{26}$ & $?$ & NA & - & + & - & NA & $?$ & 1 \\
\hline Edwards $2017^{27}$ & + & NA & - & + & - & NA & NA & 1 \\
\hline Friis $2015^{28}$ & - & NA & + & - & - & NA & NA & 1 \\
\hline Hall $2014^{29}$ & - & NA & + & + & + & - & $?$ & 3 \\
\hline Hammes $2010^{30}$ & - & - & - & + & + & + & $?$ & 3 \\
\hline Hickman $2016^{31}$ & + & NA & + & + & - & NA & NA & 3 \\
\hline Jacobs $2015^{32}$ & + & NA & + & + & + & NA & + & 5 \\
\hline Kazmerski $2016^{33}$ & + & NA & - & + & - & NA & $?$ & 2 \\
\hline Ko $2016^{34}$ & + & NA & + & + & - & - & $?$ & 3 \\
\hline Lyon $2017^{35}$ & + & NA & + & + & - & + & + & 5 \\
\hline Pecanac $2014^{36}$ & + & $?$ & + & + & + & + & $?$ & 5 \\
\hline Ratner $2001^{37}$ & - & NA & - & + & + & NA & $?$ & 2 \\
\hline Smith $2017^{38}$ & + & NA & + & + & - & NA & - & 3 \\
\hline
\end{tabular}




\section{Table A4. Mixed-method studies, risk of bias assessment quantitative part}

\begin{tabular}{|c|c|c|c|c|c|c|c|}
\hline \multicolumn{8}{|c|}{ Risk of Bias Assessment Trials: Cochrane Risk of Bias Tool } \\
\hline & $\begin{array}{c}\text { Random } \\
\text { sequence } \\
\text { generation }\end{array}$ & $\begin{array}{c}\text { Allocation } \\
\text { concealment }\end{array}$ & $\begin{array}{l}\text { Blinding of } \\
\text { participants }\end{array}$ & $\begin{array}{c}\text { Blinding of } \\
\text { outcome } \\
\text { assessment }\end{array}$ & $\begin{array}{c}\text { Incomplete } \\
\text { outcome } \\
\text { data }\end{array}$ & $\begin{array}{l}\text { Selective } \\
\text { reporting }\end{array}$ & Total score \\
\hline Huang $2016^{39}$ & $?$ & $?$ & - & - & + & $?$ & 1 \\
\hline Metzger $2016^{40}$ & + & + & - & $?$ & + & - & 3 \\
\hline Song $2009^{41}$ & + & + & - & $?$ & + & $?$ & 3 \\
\hline
\end{tabular}

Risk of Bias Assessment Observational studies: Adapted risk of bias assessment tool

\begin{tabular}{|c|c|c|c|c|c|c|c|c|}
\hline & $\begin{array}{c}\text { Selection } \\
\text { process of } \\
\text { study } \\
\text { population }\end{array}$ & $\begin{array}{c}\text { Comparability } \\
\text { of compared } \\
\text { groups }\end{array}$ & $\begin{array}{l}\text { Standardized } \\
\text { protocol for } \\
\text { the ACP } \\
\text { intervention }\end{array}$ & $\begin{array}{l}\text { Standardized } \\
\text { protocol for } \\
\text { measuring } \\
\text { the outcome }\end{array}$ & $\begin{array}{l}\text { Missing } \\
\text { data with } \\
\text { regard to } \\
\text { inclusion or } \\
\text { follow-up or } \\
\text { outcomes }\end{array}$ & $\begin{array}{l}\text { Adjustment } \\
\text { for } \\
\text { confounders }\end{array}$ & $\begin{array}{l}\text { Selective } \\
\text { outcome } \\
\text { reporting }\end{array}$ & $\begin{array}{l}\text { Total } \\
\text { score }\end{array}$ \\
\hline Borreani $2008^{42}$ & - & NA & - & NA & - & NA & NA & 0 \\
\hline Borreani $2012^{43}$ & - & - & - & NA & - & - & NA & 0 \\
\hline Chan $2014^{44}$ & $?$ & NA & - & + & - & - & - & 1 \\
\hline O'Connor $2016^{45}$ & - & NA & + & - & + & NA & $?$ & 2 \\
\hline Lum $2016^{46}$ & - & NA & + & - & - & - & $?$ & 1 \\
\hline Lum $2017^{47}$ & + & NA & + & + & - & NA & $?$ & 3 \\
\hline Rocque $2017^{48}$ & - & NA & - & + & - & NA & $?$ & 1 \\
\hline Whitehead $2016^{49}$ & - & NA & NA & + & - & NA & $?$ & 1 \\
\hline
\end{tabular}


Table A5. Mixed-method studies, assessment of quality of reporting qualitative part, COREQ ${ }^{50}$

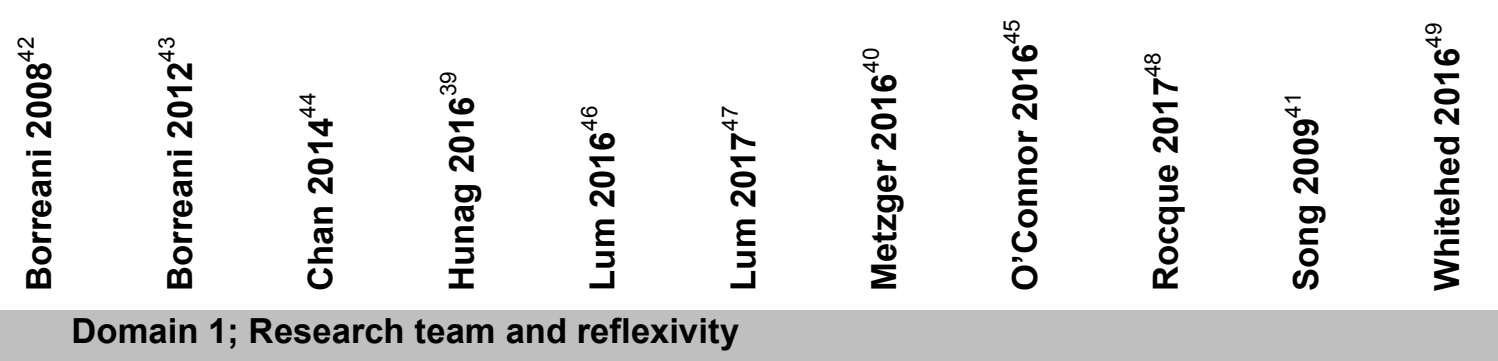

\section{Personal characteristics}

1. Interviewer/facilitator

2. Credentials

3. Occupation

4. Gender

5. Experiences or training

Relationship with participants

\section{Relationship established}

7. Participant knowledge of the interviewer

8. Interviewer characteristics

NA

\section{Domain 2; Study design}

Theoretical framework

9. Methodological orientation

\section{Participant selection}

\section{Sampling}

11. Method of approach 
12. Sample size

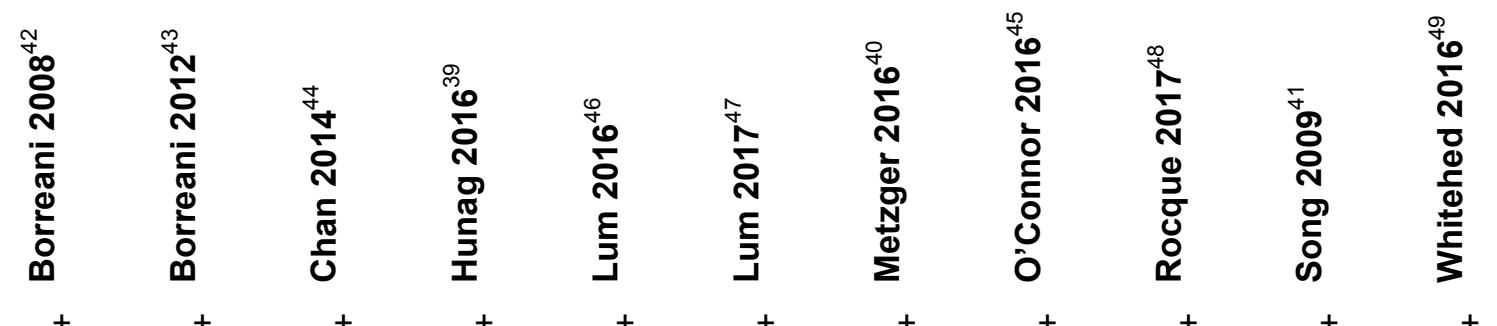

13. Non-participation

\section{Setting}

14. Setting of data collection

15. Presence of non-participants

16. Description of sample

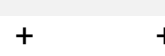

$\begin{array}{ll}- & \text { NA } \\ +/- & +\end{array}$

Data collection

17. Interview guide

18. Repeat interview

19. Audio-visual recording

20. Field notes

21. Duration

22. Data saturation

23. Transcripts returned

\section{Domain 3; Analysis and findings}

Data analysis

25. Description of coding three 
26. Derivation of themes

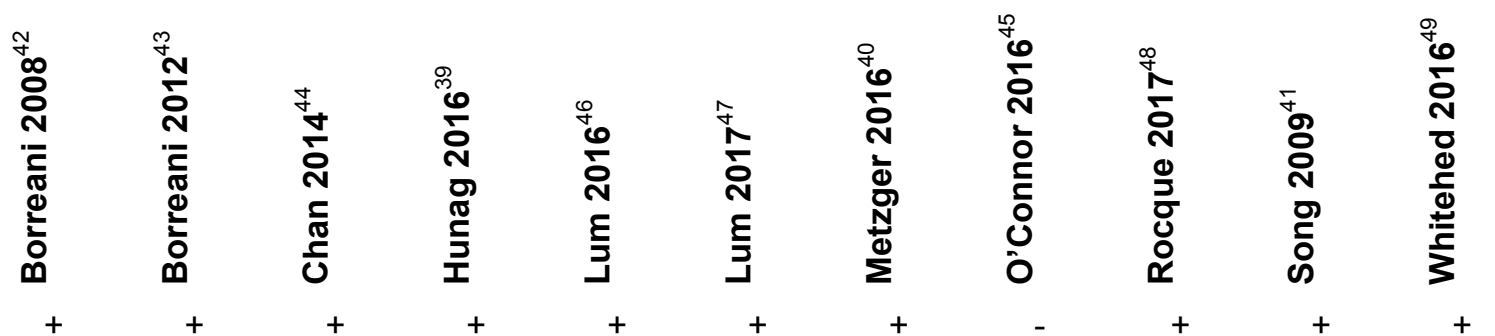

\section{Software}

28. Participant checking

\section{Reporting}

29. Quotations presented

30. Data and findings consistent

31. Clarity of major themes

32. Clarify of minor themes

\begin{tabular}{|c|c|c|c|c|c|c|c|c|c|c|c|}
\hline Total + & 8 & 11 & 14 & 14 & 17 & 14 & 12 & 3 & 15 & 16 & 15 \\
\hline Total +/- & 1 & 2 & 2 & 2 & 3 & 1 & 5 & 0 & 0 & 2 & 4 \\
\hline Total - & 23 & 13 & 16 & 15 & 12 & 16 & 14 & 28 & 16 & 12 & 12 \\
\hline Total? & 1 & 1 & 1 & 1 & 1 & 1 & 1 & 1 & 1 & 1 & 1 \\
\hline Total NA & 0 & 6 & 0 & 1 & 0 & 0 & 1 & 0 & 0 & 1 & 0 \\
\hline Total score & 8.5 & 12 & 15 & 15 & 18.5 & 14.5 & 14.5 & 3 & 15 & 17 & 17 \\
\hline
\end{tabular}

$\mathrm{NA}=$ not applicable; $+=$ criterion properly described, a score of 1 was assigned; - criterion not described, a score of 0 was assigned; $+/-$ criterion incomplete described, a score of 0.5 was assigned; ?= criterion not possible to assess, no score was assigned 
Table A6. Qualitative studies, assessment of quality of reporting, COREQ ${ }^{50}$

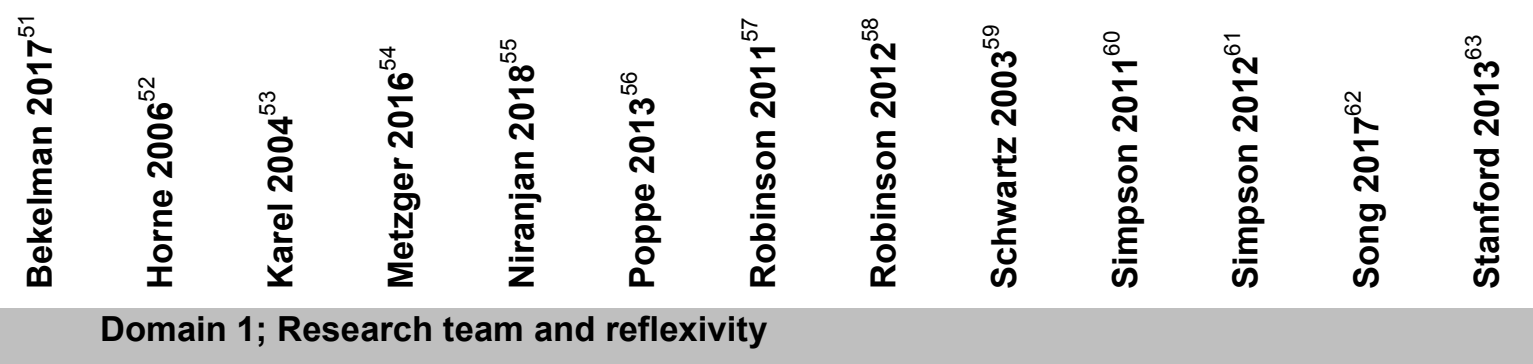

\section{Personal characteristics}
1. Interviewer/facilitator
2. Credentials
3. Occupation
4. Gender
5. Experiences or training

Relationship with participants
6. Relationship established
7. Participant knowledge of the interviewer
8. Interviewer characteristics

\section{Domain 2; Study design}

Theoretical framework

9. Methodological orientation

Participant selection

10. Sampling

11. Method of approach 
12. Sample size

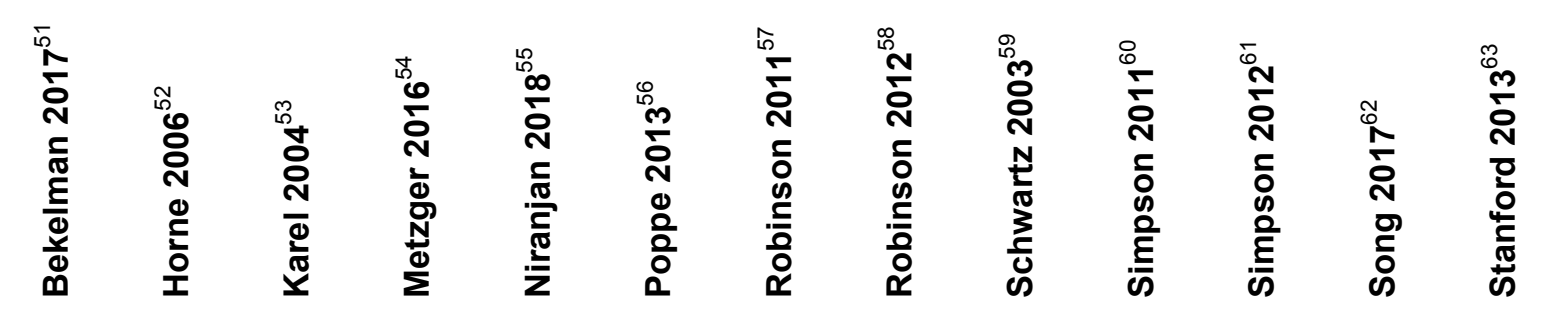

13. Non-participation

Setting

14. Setting of data collection

15. Presence of non-participants

16. Description of sample

17. Interview guide

18. Repeat interview

19. Audio-visual recording

20. Field notes

21. Duration

22. Data saturation

23. Transcripts returned

\section{Domain 3; Analysis and findings}

\section{Data analysis}

24. Number of data codes

25. Description of coding three

$+\quad+$

\section{Data collection}


26. Derivation of themes

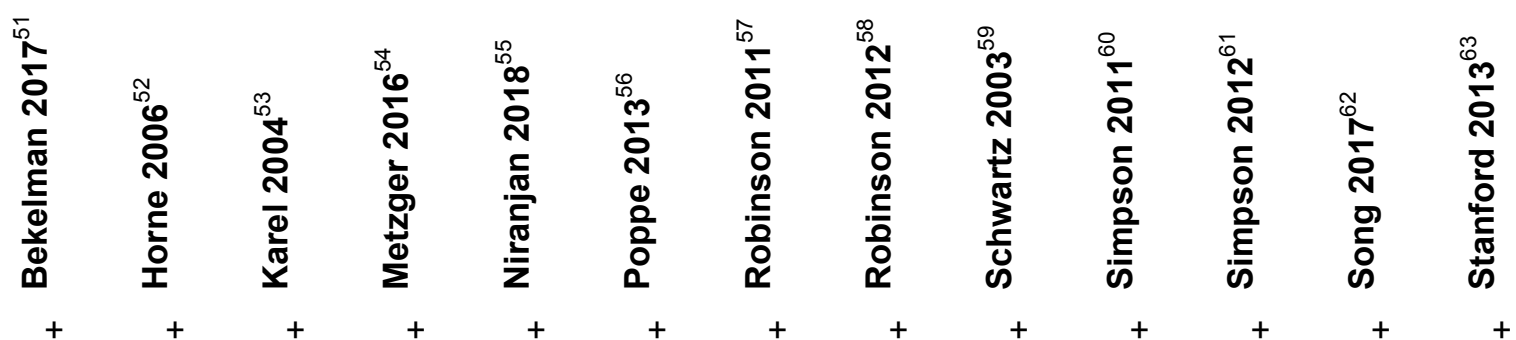

27. Software

28. Participant checking

\section{Reporting}

29. Quotations presented

30. Data and findings consistent

31. Clarity of major themes

32. Clarify of minor themes

\begin{tabular}{|c|c|c|c|c|c|c|c|c|c|c|c|c|c|}
\hline Total + & 16 & 17 & 21 & 15 & 16 & 18 & 11 & 15 & 15 & 16 & 15 & 16 & 13 \\
\hline Total +/- & 1 & 1 & 0 & 1 & 1 & 2 & 3 & 1 & 4 & 2 & 1 & 0 & 0 \\
\hline Total - & 14 & 13 & 11 & 14 & 14 & 12 & 18 & 16 & 13 & 14 & 16 & 15 & 18 \\
\hline Total ? & 1 & 1 & 1 & 1 & 1 & 1 & 1 & 1 & 1 & 1 & 1 & 1 & 1 \\
\hline Total NA & 0 & 0 & 0 & 1 & 0 & 0 & 0 & 0 & 0 & 0 & 0 & 0 & 0 \\
\hline Total score & 16.5 & 17.5 & 21 & 15.5 & 16.5 & 19 & 12.5 & 15.5 & 17 & 17 & 15.5 & 16 & 13 \\
\hline
\end{tabular}

$\mathrm{NA}=$ not applicable; + = criterion properly described, a score of 1 was assigned; - criterion not described, a score of 0 was assigned; +/- criterion incomplete described, a score of 0.5 was assigned; ?= criterion not possible to assess, no score was assigned 
Table A7. Evidence from qualitative studies

\begin{tabular}{|c|c|c|c|}
\hline Author, year, & $\begin{array}{l}\text { Aim and } \\
\text { methods }\end{array}$ & Population $\quad$ Outcomes & $\begin{array}{l}\text { Quality of } \\
\text { reporting }\end{array}$ \\
\hline country & & no. & $T$ Th1 \\
\hline
\end{tabular}

\section{ACP in COPD}

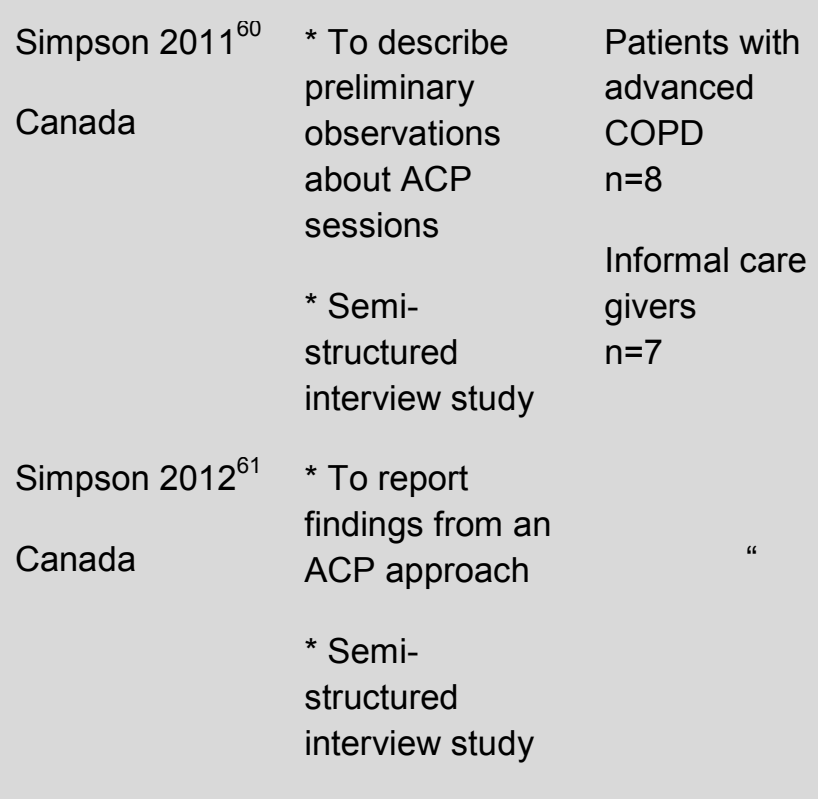

* EOL is a difficult, if not a taboo subject. There was Initial resistance in $6 / 8$ patients, but in the end all were able to discuss EOL-concerns

* Talking about illness concerns and experiences with an interested clinician made patients feel having their questions and concerns heard and answered. They felt the opportunity to learn more about end-of-life care options, preferences and documentation

* The approach was both acceptable and meaningful and left participants with hope intact

* Patients felt heard and cared for and more informed about COPD and medical, ethical, and legal aspects of ACP

* No patient expressed negative comment about the experience

* The session felt as 'breaching imposed silence', as having a chance to consider values and preferences and clarify wishes

* Half of patients had a discussion with surrogate

* Half of patients started creating or completed an AD

* ACP approach was not only acceptable but appreciated and not detrimental to hope

\section{ACP in early dementia (APC-ED)}

Poppe $^{56} 2013$

UK

\section{* To explore the acceptability of ACP-ED}

* Semistructured interview study
Patients with early (mild) dementia and their carers $\mathrm{n}=12$ patients $\mathrm{n}=8$ carers $\mathrm{n}=6 \mathrm{HCP}$
* Patients reported ACP gave time to think about future and patients were more relieved, less worried and reassured about family support. * Surrogates reported ACP made them think about the future, prompted further discussions, gave opportunity to find out patient's wishes, brought relief and more confidence for decision-making * Most patients and all surrogates had positive experience

* Patients, carers and staff said all relevant issues were covered * Staff members found tool useful and flexible in facilitating discussions 


\section{ACP for patients with inoperable lung cancer}

$\begin{array}{lll}\text { Horne }{ }^{52} 2006 & \text { * } \text { To develop } & \text { Patients with } \\ \text { UK } & \text { and pilot an ACP } & \text { inoperable } \\ & \text { intervention } & \begin{array}{l}\text { lung cancer } \\ \mathrm{n}=15\end{array} \\ & \text { * Semi- } & \\ & \text { structured } & \text { Family members } \\ & \text { interview study } & \mathrm{n}=6\end{array}$

* Most patients were positive regarding the discussion and felt better for it. Some patients found it quite a 'personal thing'. Patients were able to express their fears and talk about what may happen at the end of life.

* Participants appreciated information given by nurse: explanation of their disease, what may happen in the future and possible options.

* All patients agreed to have a written record of their preferences for future care in the EHR. They differed in their expected concordance between their recorded preferences and actual care

* Three out of four patients who died during the data collection period had expressed a preference to die at home and fulfilled their wish

* Family members' reactions varied between being grateful for opening the discussion and preferring not to think ahead and 'live one day at a time'.

\section{I14. Goals of Care Communication Guide}

$\begin{array}{lll}\begin{array}{l}\text { Bekelman } \\ 2017^{51}\end{array} & \begin{array}{l}\text { * To determine } \\ \text { the feasibility of } \\ \text { the guide }\end{array} & \begin{array}{l}\text { Patients with heart } \\ \text { failure or COPD }\end{array} \\ \text { USA } & \text { * Semi- } & \mathrm{n}=15 \text { patients } \\ & \begin{array}{l}\text { and } 5 \text { informal } \\ \text { structured } \\ \text { interview study }\end{array} & \text { caregivers } \\ & \end{array}$

* Goals of care communication declared to be an important topic * The conversation had an acceptable length, flowed well and was clear

\section{I18. Living Well Interview}

\begin{tabular}{|c|c|c|c|c|}
\hline $\begin{array}{l}\text { Schwartz } \\
2003^{59} \\
\text { USA }\end{array}$ & $\begin{array}{l}{ }^{*} \text { To identify the } \\
\text { best subset of } \\
\text { questions and to } \\
\text { examine } \\
\text { interrelationships } \\
\text { between themes } \\
{ }^{*} \text { Content } \\
\text { analysis of } \\
\text { conversations }\end{array}$ & $\begin{array}{l}\text { Terminally ill } \\
\text { patients } \\
\mathrm{n}=52\end{array}$ & $\begin{array}{l}\text { *A question about hope for those closest to the patient evoked most } \\
\text { emotion } \\
\text { * Questions about events to look forward to, about religious or spiritual } \\
\text { beliefs and about meaningfulness of this life time tended not to be } \\
\text { asked or answered }\end{array}$ & 17 of 32 \\
\hline
\end{tabular}

125. Respecting Choices (RC) 


\begin{tabular}{|c|c|c|c|c|}
\hline $\begin{array}{l}\text { Robinson } \\
2011^{57} \\
\text { USA }\end{array}$ & $\begin{array}{l}\text { * To explore the } \\
\text { applicability and } \\
\text { usefulness of } \\
\text { RC } \\
\text { * Semi- } \\
\text { structured } \\
\text { interview study }\end{array}$ & $\begin{array}{l}\text { Patients } \\
\text { diagnosed with } \\
\text { advanced lung } \\
\text { cancer and a } \\
\text { family } \\
\text { member } \\
\mathrm{n}=9 \text { dyads }\end{array}$ & $\begin{array}{l}{ }^{*} \text { All participants evaluated the intervention as difficult but helpful } \\
\text { * The patient-centered, individual focus of the questions was shifted } \\
\text { towards a family-centered, relational focus by the participants } \\
\text { * Patients acknowledged closeness and importance of the relationship } \\
\text { with their participating family members } \\
\text { * Dyads demonstrated mutual support through family solidarity, } \\
\text { particularly around hopes for the plan of care }\end{array}$ & 12.5 of 32 \\
\hline $\begin{array}{l}\text { Robinson } \\
2012^{58} \\
\text { USA }\end{array}$ & $\begin{array}{l}\text { * To explore the } \\
\text { process and } \\
\text { outcomes of RC } \\
\text { * Semi- } \\
\text { structured } \\
\text { interview study }\end{array}$ & “ & $\begin{array}{l}\text { * The dyads found the ACP interview helpful, important, and, although } \\
\text { very emotional, easier than anticipated. } 1 \text { dyad stopped the interview, } \\
\text { as the proxy was overwhelmed } \\
\text { * There was no interference between ACP and hope for cure, hope } \\
\text { restrained during the interviews and over time }\end{array}$ & 15.5 of 32 \\
\hline $\begin{array}{l}\text { Niranjan } 2018^{55} \\
\text { USA }\end{array}$ & $\begin{array}{l}\text { * To explores } \\
\text { barriers and } \\
\text { facilitators in } \\
\text { initiating RC- } \\
\text { conversations } \\
\text { * Semi } \\
\text { structured } \\
\text { interview study }\end{array}$ & $\begin{array}{l}\text { Lay patient } \\
\text { navigators } \\
\mathrm{n}=26\end{array}$ & $\begin{array}{l}{ }^{*} \text { Key facilitators for ACP-conversations: physician buy-in, patient } \\
\text { readiness, and navigators' prior experience with end-of-life decision- } \\
\text { making } \\
{ }^{*} \text { Challenges to initiating ACP conversations: timing of the } \\
\text { conversation and social and personal taboos about discussing dying }\end{array}$ & 16.5 of 32 \\
\hline
\end{tabular}




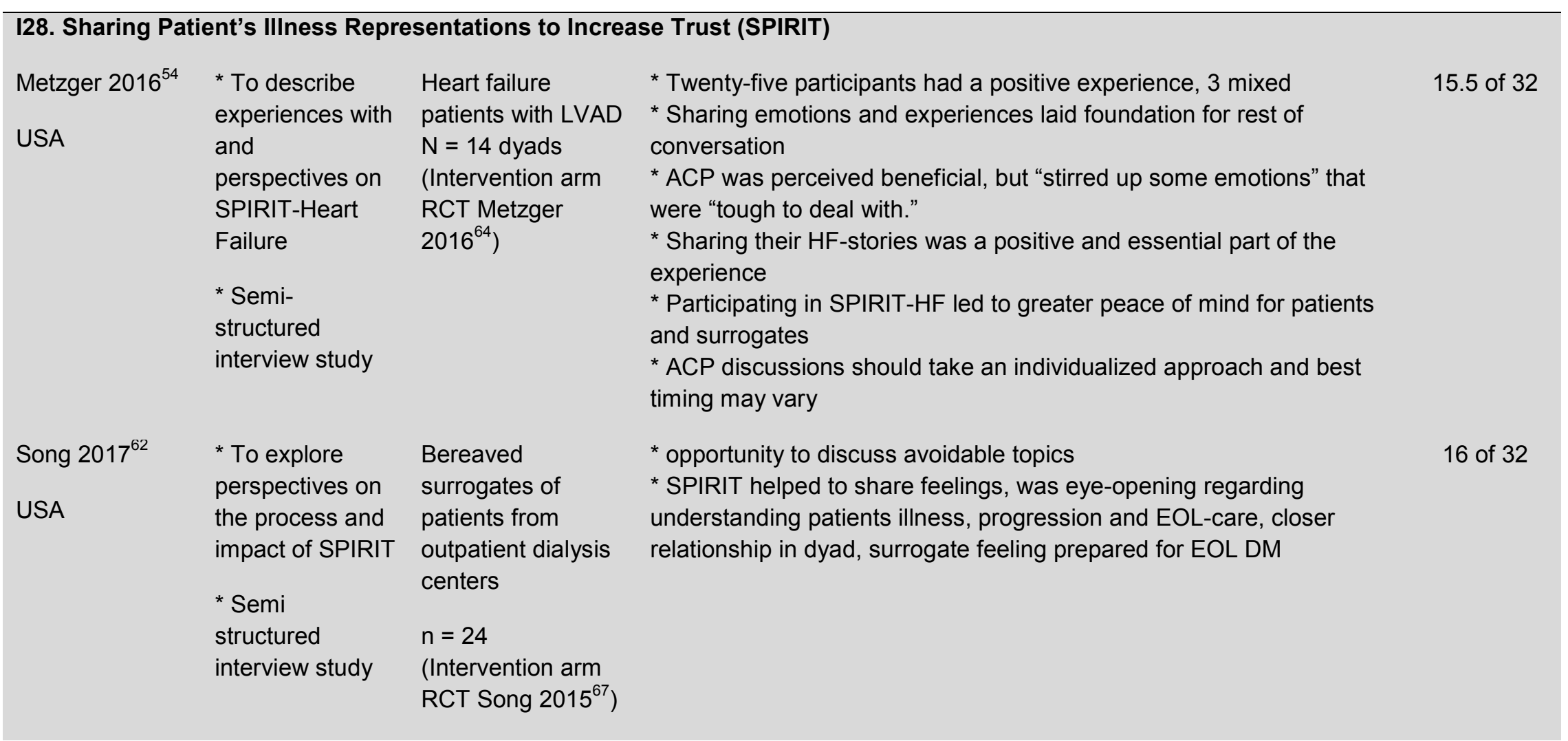

\section{The One Slide}

\begin{tabular}{|c|c|c|}
\hline $\begin{array}{l}\text { Stanford } 2013^{63} \\
\text { South-Africa }\end{array}$ & $\begin{array}{l}\text { * } \text { To determine } \\
\text { perceived } \\
\text { relevance of }\end{array}$ & $\begin{array}{l}\text { Hospice staff, } \\
\text { teachers and } \\
\text { pastors }\end{array}$ \\
\hline & $\begin{array}{l}\text { ACP and refine } \\
\text { a tool for } A C P\end{array}$ & $\mathrm{n}=51$ \\
\hline
\end{tabular}

* Focus group

study

* ACP conversations and formalizing wishes is worthwhile, but implementing whishes might be difficult, i.e. regarding dying at home

* Discussion should take place before advanced illness, as early as possible. The taboo of speaking about death is a barrier

* Advocacy is needed to improve ACP awareness

* Family or proxies should be involved in ACP

* Strong support for the concept and utility of using the One Slide 


\begin{tabular}{|c|c|c|c|c|}
\hline \multicolumn{5}{|c|}{ 133. Value Discussion Guide (VDG) } \\
\hline $\begin{array}{l}\text { Karel } 2004^{53} \\
\text { USA }\end{array}$ & $\begin{array}{l}\text { * To describe } \\
\text { experiences with } \\
\text { VDG with and } \\
\text { without a } \\
\text { facilitator } \\
\text { * Semi- } \\
\text { structured } \\
\text { interview study }\end{array}$ & $\begin{array}{l}\text { Male veterans }> \\
50 \\
\text { years with } A D \text { and } \\
\text { their surrogate } \\
n=10 \text { dyads }\end{array}$ & $\begin{array}{l}\text { * } 40 \% \text { preferred facilitated discussion, } 10 \% \text { preferred self-guided } \\
\text { discussion, } 20 \% \text { differed in preference, } 30 \% \text { had no preference } \\
\text { * Discussions resulted in improved or confirmed understanding } \\
\text { between veteran and surrogate and clarification of surrogates role } \\
\text { * Several surrogates hoped ACP could prevent feelings of guilt later } \\
\text { on } \\
\text { * Sharing stories about prior experiences with EOL decisions provided } \\
\text { opportunity for emotional connection. } \\
\text { * None perceived discussions as upsetting, yet emotional. None quit } \\
\text { the interview, but several participants were sad or crying } \\
\text { * Guide was perceived acceptable and providing a helpful structure }\end{array}$ & 21 of 32 \\
\hline
\end{tabular}

ACP = advance care planning; AD = Advance Directive; COPD = Chronic Obstructive Pulmonary Disease; EHR = Electronic Health Record; $\mathrm{EOL}=$ End of Life; DM = Decision Making; HF = Heart Failure; RCT = Randomized Controlled Trial; LVAD = Left Ventricular Assisted Device 


\section{References}

1. Higgins J, Green S. Cochrane Handbook for Systematic Reviews of Interventions. Version 5. The Cochrane Collaboration; 2011. http://handbook.cochrane.org.

2. Au DH, Udris EM, Engelberg RA, et al. A Randomized Trial to Improve Communication About Endof-Life Care Among Patients With COPD. Chest. 2012;141(3):726-735.

3. Briggs L a., Kirchhoff KT, Hammes BJ, Song MK, Colvin ER. Patient-centered advance care planning in special patient populations: A pilot study. J Prof Nurs. 2004;20(1):47-58.

4. Chan HYL, Pang SMC. Let me talk - an advance care planning programme for frail nursing home residents. J Clin Nurs. 2010;19(21-22):3073-3084.

5. Dallas RH, Kimmel A, Wilkins ML, et al. Acceptability of Family-Centered Advanced Care Planning for Adolescents With HIV. Pediatrics. 2016;138(6):e20161854-e20161854.

6. Fischer SM, Cervantes L, Fink RM, Kutner JS. Apoyo con Carino: a pilot randomized controlled trial of a patient navigator intervention to improve palliative care outcomes for Latinos with serious illness. J Pain Symptom Manag. 2015;49(4):657-665.

7. Hilgeman MM, Allen RS, Snow AL, Durkin DW, Decoster J, Burgio L. Preserving Identity and Planning for Advance Care (PIPAC): Preliminary outcomes from a patient-centered intervention for individuals with mild dementia. Aging Ment Heal. 2014;18(4):411-424.

8. Kirchhoff KT, Hammes BJ, Kehl KA, Briggs LA, Brown RL. Effect of a Disease-Specific Planning Intervention on Surrogate Understanding of Patient Goals for Future Medical Treatment. J Am Geriatr Soc. 2010;58(7):1233-1240.

9. Kirchhoff KT, Hammes BJ, Kehl K a., Briggs L a., Brown RL. Effect of a disease-specific advance care planning intervention on end-of-life care. J Am Geriatr Soc. 2012;60(5):946-950.

10. Lakin JR, Koritsanszky LA, Cunningham R, et al. A Systematic Intervention To Improve Serious Illness Communication In Primary Care. Health Aff (Millwood). 2017;36(7):1258-1264.

11. Lyon ME, Garvie P a, Briggs L, He J, McCarter R, D'Angelo LJ. Development, feasibility, and acceptability of the Family/Adolescent-Centered (FACE) Advance Care Planning intervention for adolescents with HIV. J Palliat Med. 2009;12(4):363-372.

12. Lyon ME, Garvie P a, McCarter R, Briggs L, He J, D'Angelo LJ. Who Will Speak for Me? Improving End-of-Life Decision-Making for Adolescents With HIV and Their Families. Pediatrics. 2009;123(2):e199-e206.

13. Lyon ME, Garvie PA, Briggs L, et al. Is it safe? Talking to teens with HIVIAIDS about death and dying: a 3-month evaluation of Family Centered Advance Care (FACE) planning - anxiety, depression, quality of life. HIV/AIDS Res Palliat Care. 2010;2:27-37.

14. Lyon ME, Garvie PA, Kao E, et al. Spirituality in HIV-infected adolescents and their families: FAmily CEntered (FACE) advance care planning and medication adherence. J Adolesc Heal. 2011;48(6):633-636.

15. Lyon ME, Jacobs S, Briggs L, Cheng YI, Wang J. Family-centered advance care planning for teens with cancer. JAMA Pediatr. 2013;167(5):460-467.

16. Lyon ME, Jacobs S, Briggs L, Cheng YI, Wang J. A longitudinal, randomized, controlled trial of advance care planning for teens with cancer: Anxiety, depression, quality of life, advance directives, spirituality. J Adolesc Heal. 2014;54(6):710-717. 
17. Lyon ME, D'Angelo LJ, Dallas $\mathrm{RH}$, et al. A randomized clinical trial of adolescents with HIVIAIDS: pediatric advance care planning. AIDS Care - Psychol Socio-Medical Asp AIDS/HIV. 2017;29(10):1287-1296.

18. Reinke LF, Feemster LC, McDowell J, et al. The long term impact of an end-of-life communication intervention among veterans with COPD. Hear Lung J Acute Crit Care. 2017;46(1):30-34.

19. Der Schmitten JI, Lex K, Mellert C, RothÄrmel S, Wegscheider K, Marckmann G. Implementing an advance care planning program in german nursing homes. Dtsch Arztebl Int. 2014;111(4):50-57.

20. Schwartz $\mathrm{CE}$, Brownell Wheeler $\mathrm{H}$, Hammes $\mathrm{B}$, et al. Early intervention in planning end-of-life care with ambulatory geriatric patients: Results of a pilot trial. Arch Intern Med. 2002;162(14):16111618.

21. Song MK, Kirchhoff KT, Douglas J, Ward S, Hammes B. A randomized, controlled trial to improve advance care planning among patients undergoing cardiac surgery. Med Care. 2005;43(10):10491053.

22. Song MK, Donovan HS, Piraino BM, et al. Effects of an intervention to improve communication about end-of-life care among African Americans with chronic kidney disease. Appl Nurs Res. 2010;23(2):65-72.

23. Song MK, Ward SE, Fine JP, et al. Advance Care Planning and End-of-Life Decision Making in Dialysis: A Randomized Controlled Trial Targeting Patients and Their Surrogates. Am J Kidney Dis. 2015;66(5):813-822.

24. Song MK, Ward SE, Lin FC, et al. Racial Differences in Outcomes of an Advance Care Planning Intervention for Dialysis Patients and Their Surrogates. J Palliat Med. 2016;19(2):134-142.

25. Stein RA, Sharpe L, Bell ML, Boyle FM, Dunn SM, Clarke SJ. Randomized Controlled Trial of a Structured Intervention to Facilitate End-of-Life Decision Making in Patients With Advanced Cancer. J Clin Oncol. 2013;31(27):3403-3410.

26. Boettcher I, Turner R, Briggs L. Telephonic advance care planning facilitated by health plan case managers. Palliat Support Care. 2015;13(3):795-800.

27. Edwards LA, Jarrell JA, Bui C, Cabrera AG. Improving outpatient advance care planning for adults with congenital or pediatric heart disease followed in a pediatric heart failure and transplant clinic. Congenit Heart Dis. 2018;(December 2017):1-7.

28. Friis P, Forde R. Advance care planning discussions with geriatric patients. Tidsskr Den Nor Laegeforening. 2015;135(3):233-235.

29. Hall NA, Jenson CE. Implementation of a Facilitated Advance Care Planning Process in an Assisted Living Facility. J Hosp Palliat Nurs. 2014;16(2):113-119.

30. Hammes BJ, Rooney BL, Gundrum JD. A Comparative, Retrospective, Observational Study of the Prevalence, Availability, and Specificity of Advance Care Plans in a County that Implemented an Advance Care Planning Microsystem. J Am Geriatr Soc. 2010;58(7):1249-1255.

31. Hickman SE, Unroe KT, Ersek MT, Buente B, Nazir A, Sachs GA. An Interim Analysis of an Advance Care Planning Intervention in the Nursing Home Setting. J Am Geriatr Soc. 2016;64(11):2385-2392.

32. Jacobs S, Perez J, Cheng YI, Sill A, Wang J, Lyon ME. Adolescent end of life preferences and congruence with their parents' preferences: Results of a survey of adolescents with cancer. Pediatr Blood Cancer. 2015;62(4):710-714. 
33. Kazmerski TM, Weiner DJ, Matisko J, et al. Advance care planning in adolescents with cystic fibrosis: A quality improvement project. Pediatr Pulmonol. 2016;51(12):1304-1310.

34. Ko E, Hohman M, Lee J, Ngo A-N, Woodruff SI. Feasibility and Acceptability of a Brief Motivational Stage-Tailored Intervention to Advance Care Planning. Am J Hosp Palliat Med. 2016;33(9):834842.

35. Lyon ME, Dallas RH, Garvie PA, et al. Paediatric advance care planning survey: a cross-sectional examination of congruence and discordance between adolescents with HIVIAIDS and their families. BMJ Support Palliat Care. 2017;(2):bmjspcare-2016-001224.

36. Pecanac KE, Repenshek MF, Tennenbaum D, Hammes BJ. Respecting Choices and advance directives in a diverse community. J Palliat Med. 2014;17(3):282-287.

37. Ratner E, Norlander L, McSteen K. Death at home following a targeted advance-care planning process at home: The kitchen table discussion. J Am Geriatr Soc. 2001;49(6):778-781.

38. Smith SL. Advance Care Planning Communication for Young Adults: A Role for Simulated Learning. J Hosp Palliat Nurs. 2017;19(5):460-467.

39. Huang C-HS, Crowther M, Allen RS, et al. A pilot feasibility intervention to increase advance care planning among African Americans in the deep south. J Palliat Med. 2016;19(2):164-173.

40. Metzger M, Song M-K, Ward S, Chang PP-Y, Hanson LC, Lin F-C. A randomized controlled pilot trial to improve advance care planning for LVAD patients and their surrogates. Heart Lung. 2016;45(3):186-192.

41. Song M-K, Ward SE, Happ MB, et al. Randomized controlled trial of SPIRIT: An effective approach to preparing African American dialysis patients and families for end of life. Res Nurs Health. 2009;32(3):260-273.

42. Borreani C, Brunelli C, Miccinesi G, et al. Eliciting Individual Preferences About Death: Development of the End-of-Life Preferences Interview. J Pain Symptom Manage. 2008;36(4):335350.

43. Borreani C, Brunelli C, Bianchi E, Piva L, Moro C, Miccinesi G. Talking about end-of-life preferences with advanced cancer patients: Factors influencing feasibility. J Pain Symptom Manage. 2012;43(4):739-746.

44. Chan $\mathrm{CWH}$, Chui YY, Chair SY, et al. The evaluation of a palliative care programme for people suffering from life-limiting diseases. J Clin Nurs. 2014;23(1-2):113-123.

45. O'Connor NR, Moyer ME, Kirkpatrick JN. Scripted Nurse Visits: A Resource-Efficient Palliative Care Model for Ventricular Assist Devices. J Palliat Med. 2016;19(12):1312-1315.

46. Lum HD, Jones J, Matlock DD, et al. Advance Care Planning Meets Group Medical Visits: The Feasibility of Promoting Conversations. Ann Fam Med. 2016;14(2):125-132.

47. Lum HD, Sudore RL, Matlock DD, et al. A Group Visit Initiative Improves Advance Care Planning Documentation among Older Adults in Primary Care. J Am Board Fam Med. 2017;30(4):480-490.

48. Rocque GB, Dionne-Odom JN, Sylvia Huang CH, et al. Implementation and Impact of Patient Lay Navigator-Led Advance Care Planning Conversations. J Pain Symptom Manage. 2017;53(4):682692.

49. Whitehead PB, Ramalingam N, Carter KF, Katz K, Harden S. Nurse Practitioners' Perspectives on the Patient Preferences About Serious Illness Instrument. J Hosp Palliat Nurs. 2016;18(4):332-341. 
50. Tong A, Sainsbury P, Craig J. Consolidated criteria for reporting qualitative research ( COREQ ): a 32-item checklist for interviews and focus groups. Int J Qual Heal Care. 2007;19(6):349-357.

51. Bekelman DB, Johnson-Koenke R, Ahluwalia SC, Walling AM, Peterson J, Sudore RL. Development and Feasibility of a Structured Goals of Care Communication Guide. J Palliat Med. 2017;20(9):jpm.2016.0383.

52. Horne G, Seymour J, Shepherd K. Advance care planning for patients with inoperable lung cancer. Int J Palliat Nurs. 2006;12(4):172-178.

53. Karel MJ, Powell J, Cantor MD. Using a Values Discussion Guide to facilitate communication in advance care planning. Patient Educ Couns. 2004;55(1):22-31.

54. Metzger M, Song MK, Devane-Johnson S. LVAD patients' and surrogates' perspectives on SPIRIT-HF: An advance care planning discussion. Hear Lung. 2016;45(4):305-310.

55. Niranjan SJ, Huang CHS, Dionne-Odom JN, et al. Lay Patient Navigators' Perspectives of Barriers, Facilitators and Training Needs in Initiating Advance Care Planning Conversations With Older Patients With Cancer. J Palliat Care. 2018;XX(X):1-9.

56. Poppe M, Burleigh S, Banerjee S. Qualitative Evaluation of Advanced Care Planning in Early Dementia (ACP-ED). PLoS One. 2013;8(4).

57. Robinson $\mathrm{C}$ a. Advance care planning: Re-visioning our ethical approach. Can J Nurs Res. 2011;43(2):18-37.

58. Robinson CA. "Our best hope is a cure." Hope in the context of advance care planning. Palliat Support Care. 2012;10(2):75-82.

59. Schwartz C, Lennes I, Hammes B, Lapham C, Bottner W, Ma Y. Honing an advance care planning intervention using qualitative analysis: the Living Well interview. J Palliat Med. 2003;6(4):593-603.

60. Simpson AC. An opportunity to care? preliminary insights from a qualitative study on advance care planning in advanced COPD. Prog Palliat Care. 2011;19(5):243-253.

61. Simpson C. Advance care planning in COPD: Care versus "code status." Chron Respir Dis. 2012;9(3):193-204.

62. Song MK, Metzger M, Ward SE. Process and impact of an advance care planning intervention evaluated by bereaved surrogate decision-makers of dialysis patients. Palliat Med. 2017;31(3):267274.

63. Stanford J, Sandberg DM, Gwyther L, Harding R. Conversations Worth Having: The Perceived Relevance of Advance Care Planning among Teachers, Hospice Staff, and Pastors in Knysna, South Africa. J Palliat Med. 2013;16(7):762-767. 
Topic lists Anticipating the future 
Topic list 1: Anticipating future care and treatment (parents)

\section{Anticipating future care}

A component of palliative care is to anticipate in order to be able to (continue to) provide high quality care.

- To what extent do you experience that professionals (doctors, nurses, case managers) look ahead with you/prepare you for future situations?

- How do you experience this looking ahead? Are you able to follow this approach?

- What (goals) do the doctors have in mind for your child? What are the doctors envisioning for your child?

To what extent do you occupy yourself with the thoughts about the moment your child will decline?

With respect to your child's situation: to what extent are you able to look ahead, and is it something that you want to/feel a need for?

- What are the thoughts you are having?

- What are your preferences? What is important to you?

- Are there things you are afraid of or things (issues/aspects) you have concerns about?

- What support do you think you will possibly need by that time?

Have there been other situations (so far) which made you look ahead or that compelled you to look ahead?

Healthcare professionals sometimes struggle to look ahead or anticipate with parents or to prepare them. Do you have any ideas or tips how professionals could best handle this? 


\section{Topic list 2: Anticipating future care and treatment (healthcare professional)}

\section{Anticipating future care}

The idea is that palliative care can benefit from anticipating care.

- Do you think anticipating care is important?

- To what extent can/could anticipating care be achieved for this child/family?

- What does anticipation/advance care mean/entail with respect to this family?

- How was anticipation/advance care formalized in this situation?

- What is/was your role in the approach to anticipating care?

- How do you view your role?

- How do you approach your role?

What do you and the child's parents envision with respect to future care (the future)? What do you aim for?

- Are you and the child's parents on the same page?

- To what extent are parents able to follow you in this approach?

- How do you try to achieve this? What is your approach?

One of the components of anticipating care is setting up a care plan/palliative protocol.

- To what extent is this applicable to this family?

- How is the care plan achieved?

- What was your role? What was the parents' role?

Are there issues/aspects you are already considering/anticipating, but which parents have not taken into consideration yet?

- What kind of issues/aspects are you already thinking about?

- What is the reason you are not (yet) discussing these issues/aspects with the parents? 
Questionnaire Survey study 
Dear colleague,

We kindly ask you to participate in this online survey about communication with seriously ill children and their families regarding their goals and preferences for future medical care and treatment. The study focuses on pediatricians acting as the primary care provider when taking care of children below the age of 18 with life-limiting or life-threatening diseases.

This survey is part of a greater research project, called 'Pediatric Advance Care Planning in ContexT' (PACT-pediatrics). This project collaborates with the following Dutch children's hospitals: Amalia Children's Hospital, Beatrix Children's hospital, Emma Children's hospital, Sophia Children's hospital, Wilhelmina Children's hospital and the Princess Máxima Centrum for Pediatric Oncology.

The aim of this project is to develop an intervention which will enable to timely discussions on future medical care and treatment with children and their families. Your opinion about communication with seriously ill children and their families will help us align this intervention with your practical clinical experiences. Completion of the questionnaire will take 10-15 minutes. We greatly appreciate your participation.

The survey consists of two parts:

1. Your personal experiences with your most recent case of a child who died

2. Your opinions regarding Advance Care Planning in general

If you have any further questions, please consult our executive researcher Jurrianne Fahner, j.c.fahner@umcutrecht.nl

Thank you for your cooperation.

Kind regards,

Prof. dr. Hans van Delden, dr. Marijke Kars and drs. Jurrianne Fahner

Julius Center for Health Sciences and Primary Care, UMCU

Prof. dr. Agnes van der Heide and dr. Judith Rietjens

Department of Public Health, Erasmus MC 


\section{Part 1}

\section{Personal experiences}

1. Have you ever been involved as the primary responsible pediatrician in the care of-a child with a lifelimiting or life-threatening disease until the child's death?

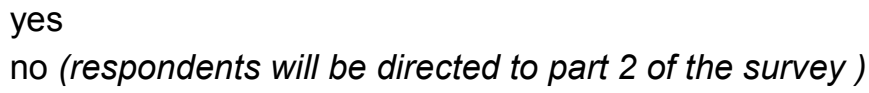

The following questions address your experiences as the primary responsible pediatrician with the most recent case of a child that died of a life-limiting or life-threatening disease.

\section{General characteristics}

2. In what year did the child die?

3. What was the child's age at death?

Age: $\square \square$ years and $\square \square$ months

4. What was the location of death?

$$
\begin{aligned}
& \text { Home } \\
& \text { Hospital } \\
& \text { Hospice } \\
& \text { Elsewhere, namely } \\
& \text { Unknown }
\end{aligned}
$$

5. What was the gender of the child?

$$
\text { Male }
$$

Female

6. What was the main diagnosis of the child?

\section{Neoplasms}

Hematological disease

Endocrine disease

Infectious disease

Metabolic disease

Mental and behavioral disorder

Disease of the nervous system

Disease of the circulatory system

Disease of the respiratory system

Disease of the digestive system

Disease of skin/subcutaneous tissue

Disease of muscular system and connective tissue

Disease of the genitourinary system

Congenital anomalies

Conditions originating in the perinatal period

Symptoms, signs and ill-defined conditions

Other, namely 
7. Which phases were included in the disease trajectory of the child?

(Please check all that apply)

Diagnostic phase

Stable phase

Phase of clinical decline

End of life period

8. During your treatment of the child, was he/she at any point able to communicate a choice, to understand the relevant information, to appreciate the medical consequences of the situation, and to reason about treatment choices?

Yes

No, due to age

No, due to developmental delay

No, due to reduced level of consciousness

No, due to emotional distress

No, due to a mental disorder

No, due to

9. For how long were you the primary responsible physician of the child?

Duration of involvement:

$\square \square$ years $\square \square$ months $\square \square$ days

10. In which phases of the disease trajectory were you involved?

(Please check all that apply)

$\square$ During the diagnostic phase

During a period of stability

During a phase of clinical decline

During the end of life period 


\section{Content of the conversations}

Which topics did you discuss with the child or the parents during your involvement as the child's physician? Please check all that apply.

Topic Child Parent

11. The child's diagnosis

12. The child's life expectancy

13. Future physical functioning of the child

14. Future social-emotional functioning of the child

15. Expected symptoms in the end of life period

16. Goals of future medical care and treatment

17. Code status or treatment limitations

18. Practical issues in the daily care for the child

19. The child's and parents' hopes

20. The child's joy in living

21. Fears and worries of the child and parents

22. Way of coping with feelings of loss and grief

23. The capacities of the family

24. Social network of the family

25. Preferences for location of death

26. Were there any goals of care or preferences for future medical care, documented in the medical record?
Yes
No
Partial

27. Did you explicitly discuss who would be the legal representative of the child?

(Please check all that apply)

Yes, with the child

Yes, with the father

Yes, with the mother

Yes, with another person, namely

No 
28. Was the legal representative of the child documented in the medical record?

Yes, both parents were documented as legal representatives

Yes, the father was documented as legal representative

Yes, the mother was documented as legal representative

Yes, someone else was documented as legal representative, namely,

No

29. Did the care provided correspond with the preferences of the child?

Not at all

Not really

Somewhat

Very much

Totally

Unclear

30. Did the provided care correspond with the preferences of the parents?

Not at all

Not really

Somewhat

Very much

Totally

Unclear

31. Did the provided care correspond with prior conversations about preferences and goals for care?

Not at all

Not really

Somewhat

Very much

Totally

32. Are you satisfied with your communication in this case?

Not at all

Not really

Somewhat

Very much

Totally

\section{Part 2 Attitudes regarding Advance Care Planning in general}

This part of the survey pertains to your opinions about conversations with children* and their parents regarding their goals and preferences for future medical care and treatment.

At the end of the survey your personal information will be asked and any additional comments can be written down.

* This concerns children below the of age 18 with a life-limiting or life-threatening disease 
In your experience, do the following issues serve as barriers to conversations with parents and children regarding their goals and preferences for future medical care and treatment?

Never Rarely $\begin{gathered}\text { Some- } \\ \text { times }\end{gathered}$ Often Very often

33. Uncertainty about diagnosis

34. Uncertainty about life expectancy

35. A lack of a trusting relationship with the child and parents

36. The inability of the child/parents to oversee their situation

37. The emotionally distressing nature of the conversation for the child/parents

38. The fear of taking away or diminishing a sense of hope

39. A language barrier

40. Cultural or religious differences

41. Divisions within the medical team regarding the child's care and treatment

42. The clinician's time constraints

43. The clinician's uncertainty about his/her communication skills

44. The emotionally distressing nature of the conversation for the clinician 
In your experience, do the following factors help facilitate conversations with parents and children regarding their goals and preferences for future medical care and treatment?

Never Rarely $\begin{gathered}\text { Some- } \\ \text { times }\end{gathered}$ Often Very often

45. Clinician continuity

46. The presence of a nurse during the conversation

47. Multidisciplinary consultation prior to the conversation

48. Assistance for the child and parents in preparing for the conversation

49. The availability of a pediatric palliative care team

50. Communication skills training for the clinician

51. The availability of a written conversation guide

52. A structured format to document the conversation

53. In your opinion, when should a conversation with children and parents about goals and preferences for care take place?

(Please check all that apply)

Upon diagnosis

During a stable phase

During clinical deterioration

In the end of life phase

Never 
Conversations about goals and preferences for future medical care and treatment...

Strongly

disagree Disagree Neutral Agree

agree

54. occur often enough in current medical practice

55. improve the quality of care

56. increase the use of palliative care

57. have to result in the documentation of a code status or treatment limitation

58. are mainly to inform the child/parents

59. put the child/parents in control

60. improve shared decision-making with the child/parents 


\section{Do you agree with the following statements:}

Strongly

disagree Disagree Neutral Agree

agree

61. I am capable of letting parents express their fears, feelings, and expectations

62. I am capable of letting children express their fears, feelings, and expectations

63. I am capable of adequately sharing bad news with parents

64. I am capable of adequately sharing bad news with children

65. I am capable of adequately discussing treatment limitations with parents

66. I am capable of adequately discussing treatment limitations with children

67. I am capable of verifying whether my conversation partners understand me correctly

68. I am capable of adequately handling emotions in conversations 


\section{Personal information}

69. What is your gender?

$$
\begin{aligned}
& \text { Male } \\
& \text { Female }
\end{aligned}
$$

70. What's your age?

$\square$ Years

71. What year did you graduate from medical school?

72. How many years have you been working as a clinician in pediatrics (including years of training after graduation from medical school)?

$\square \square$ years

73. What is your subspecialty?

(Please check all that apply)

$\square \quad$ General pediatrics
$\square \quad$ Allergology
$\square \quad$ Cardiology
$\square \quad$ Endocrinology
$\square \quad$ Genetic and Congenital disorders
$\square \quad$ Gastro enterology
$\square \quad$ Hematology
$\square \quad$ Infectious diseases/immunology
$\square \quad$ Intensive Care
$\square \quad$ Metabolic diseases
$\square \quad$ Nephrology
$\square \quad$ Neonatology
$\square \quad$ Neurology
$\square \quad$ Oncology
$\square \quad$ Pulmonology
$\square \quad$ Rheumatology/immunology
$\square \quad$ Social pediatrics
$\square \quad$ Other, namely

Any additional comments:

Thank you very much for completing this survey! 
Topic lists Developmental phase 


\section{Topic list 1: Development phase (parents)}

Anticipating the future

- Do/did you look forward to your child's future?

- When you look/looked forward to the future of your child, what thoughts come/came to your mind?

- What do/did you consider to be important when thinking about your child's future?

Sharing perspectives about the future

- Do/did you talk with your pediatrician about your child's future? Or with other clinicians?

- Which topics do/did you talk about? Where there any topics you could not discuss about with your child's clinicians?

- Do/did you talk about your child's prognosis? How is/was that feeling for you?

- Do/did you talk about what is important to you when thinking about your child's future?

- Do/did you talk about future scenario's regarding your child's condition?

- Would you like to see anything different in conversations with clinicians?

Experiences with thinking about ACP topics

- How do/did you think about your hopes for your child? How do you value talking about hopes?

- Do/did you talk about your fears and worries?

- Do/did you have any experiences with treatment limitations? What experiences?

- What future goals do/did you aim for with your child?

- Is/was there anything you certainly did not want for your child's future?

Views on decision making

- What is/was your role in decision making regarding your child's future care and treatment?

- How do/did your perspectives on the future play a role in decision making regarding your child's future care and treatment? 


\section{Topic list 2: Development phase (children)}

Anticipating the future

- Do you look forward to your future?

- When you look forward to the future, what thoughts come to your mind?

Sharing perspectives about the future

- Do you talk with your pediatrician or nurse about your future? How do you feel about that? Do they know what is important to you?

Views on decision making

- What is your role in decision making about your care and treatment?

- How do your perspectives on the future play a role in there?

Information leaflet IMPACT

- What do you think about the IMPACT information leaflet for children?

- Which questions from the leaflet do you like?

- Which questions don't you like?

- Do you think these questions and topics are appropriate for your situation?

- Do you think you could answer these questions?

- Would you like to talk about these questions and topics with your pediatricians or nurse? Why? Why not? 


\section{Topic list 3: Developmental phase (clinicians)}

Experiences with discussions about future care and treatment

- Do you speak with children or their parents about the child's future and future care and treatment? How do you set up such conversations?

- What are triggers to talk about the future?

- What is the role of prognostication or prognostic uncertainty?

- Are there any factors that complicate or facilitate discussions about the future?

- What do you aim for when discussing future care and treatment with children or parents?

- What themes do you discuss in such conversations?

- Do you have sufficient attention for the child's future in your patient encounters?

- What is your experience with discussing treatment limitations?

- How do you document any conversations about future care and treatment?

Content of advance care planning

- How do you explore the child's and parents' perspectives regarding the child's condition and the future?

- Do you explore what their values are? Or what they consider important? And what they hope for? And if they have any fears and worries?

- Do you explore these themes with parents or with children themselves as well? Does the child has a voice in those conversations?

- Who do you involve in the conversations? Why?

- How do you experience the balance between the parents' wishes and the best interests of the child?

Feasibility and effectiveness of advance care planning

- Do you experience any added value of the exploration of values, goals and preferences for future care and treatment with children and their parents?

- How can family values be integrated in future care and treatment? 
- Do you perceive any benefits from sharing goals/hopes/fears/worries in guiding future care and treatment?

- Do the conversations have any effect on shared decision making?

- Do you think advance care planning needs to be implemented in pediatric care?

- Does ACP occur sufficiently in pediatric practice?

- What are pros and cons?

- How do you think clinicians, parents and children you work with see the concept of ACP? 
Topic lists Pilot phase 


\section{Topic list 1 Pilot phase (parents)}

Background child

- Could you tell me something about your child and family? How is you child doing at the moment?

Rating ACP conversation

- How do you value the conversation with your physician/nurse on a scale from 0-10?

Experiences ACP conversation

- What do you think about the conversation?

- What did you like to talk about? What didn't you like to talk about?

- Where there any difficult topics to talk about?

- What topics did you consider most important?

- Did you miss any topics you consider important?

- Where there any differences between this conversation and the regular appointments with your child's clinician?

- Do you think your child's clinician heard any new information from you during the conversation? Did you hear anything new in the conversation?

- How did you feel during the conversation? Did you feel heard?

\section{Effect ACP conversation}

- What do you remember of the conversation?

- Did you talk about it with others afterwards? With your spouse for example?

○ Did you write anything down after the conversation?

- Did the conversation change your view on your child's future, disease, treatment or clinician? How do you feel about that?

- Do you think there will follow any changes in your child's care and treatment based on the conversation? Is there anything you would like to be different based on the conversation? 
- Would you like to have a follow-up conversation? What would you talk about then?

- Would you recommend a conversation like this to other children or families?

- How can we improve such conversations?

\section{Materials IMPACT}

- What do you think about the information leaflet to prepare for the conversation?

- Did you have any expectations about the conversations in advance?

- Did you use think about the questions in the leaflet prior to the conversation? Did you talk about the questions in the booklet with someone else before the conversation? 


\section{Topic list 2 Pilot phase (children)}

Background child

- Could you tell me something about who you are? How about your illness at this moment?

Rating ACP conversation

- How do you value the conversation with your physician/nurse on a scale from 0-10?

Experiences ACP conversation

- What do you think about the conversation?

○ What did you like to talk about? What didn't you like to talk about?

- Where there any difficult topics to talk about?

- What topics did you consider most important?

- Did you miss any topics you consider important?

- Where there any differences between this conversation and the regular appointments with your clinician?

- Do you think your clinician or your parents heard any new information from you during the conversation? Did you or your parents hear anything new in the conversation?

- How did you feel during the conversation? Did you feel heard?

Effect ACP conversation

- What do you remember of the conversation?

○ Did you talk about it with others afterwards? With your parents for example?

- Did you write anything down after the conversation?

- Did the conversation change your view on your future, your disease, your treatment, your family or your clinician? How do you feel about that?

- Do you think there will follow any changes in your care and treatment based on the conversation? Is there anything you would like to be different based on the conversation?

- Would you like to have a follow-up conversation? What would you talk about then? 
- Would you recommend a conversation like this to other children or families?

- How can we improve such conversations?

Materials IMPACT

- What do you think about the information leaflet to prepare for the conversation?

- Did you have any expectations about the conversations in advance?

- Did you use the fill-in booklet? Did you talk about the questions in the booklet with someone else before the conversation? 


\section{Topic list 3 Pilot phase (clinicians)}

\section{Rating ACP conversations}

- How do you value the ACP conversations you conducted during the pilot study on a scale from $0-10 ?$

\section{Experiences ACP conversations}

- How do you look back on the conversations?

○ What went well?

- What would you like to do differently?

- Where there any difficult topics to discuss?

- To what extent were the conversations different from your regular patient encounters?

- Did you experience any difficulties to integrate the ACP conversations in your daily practice?

- How did you feel during the conversations and afterwards?

- How did your conversation partners react during the conversations?

\section{Effect ACP conversations}

- Did the conversations change your view on the child or family?

- What do you get out of the conversations as a clinician?

- To what extent did the conversations influence planning of future care and treatment? Do the conversations have any influence on (medical) decision making?

Materials IMPACT

- What do you think about the IMPACT training? Did you use it in daily practice?

- $\quad$ Did you use the verbal examples during the conversations?

- What do you think about the conversation guide?

- What do you think about the documentation of the conversations? 
- Did you use IMPACT (materials or training) in your work apart from the conversations included in the study? Will you use any elements in your work now the study has ended?

- Do you think ACP conversations have to be part of regular care? Why or why not? Who needs to be involved in ACP? What are next steps in the implementation of ACP in pediatrics? 


\section{List of Publications}

Fahner JC, Beunders AJM, van der Heide A, Rietjens JAC, Vanderschuren MM, van Delden JJM, Kars MC. Interventions Guiding Advance Care Planning Conversations: A Systematic Review. J Am Med Dir Assoc. 2019 Mar;20(3):227-248. doi: 10.1016/j.jamda.2018.09.014. Epub 2018 Nov 22.

Fahner JC, Rietjens JAC, van der Heide A, van Delden JJM, Kars MC. Survey of paediatricians caring for children with life-limiting conditions found that they were involved in advance care planning. Acta Paediatr. 2020 May;109(5):1011-1018. doi: 10.1111/apa.15061. Epub 2019 Nov 20.

Fahner JC, Thölking TW, Rietjens JAC, van der Heide A, van Delden JJM, Kars MC. Towards Advance Care Planning in Pediatrics: A Qualitative Study on Envisioning the Future as Parents of a Seriously Ill Child Eur J Pediatr. 2020 Mar 19. doi: 10.1007/s00431-020-03627-2. Online ahead of print.

Fahner JC, Rietjens JAC, van der Heide A, Milota MM, van Delden JJM, Kars MC. Evaluation Showed That Stakeholders Valued the Support Provided by the Implementing Pediatric Advance Care Planning Toolkit. Acta Paediatr. 2020 May 20. doi: 10.1111/apa.15370. Online ahead of print.

Kochen EM, Jenken F, Boelen PA, Deben LMA, Fahner JC, van den Hoogen A, Teunissen SCCM, Geleijns K, Kars MC. When a child dies: a systematic review of well-defined parent-focused bereavement interventions and their alignment with grief- and loss theories. BMC Palliat Care. 2020 Mar 12;19(1):28. doi: 10.1186/s12904-020-0529-z. 